\title{
APLICAÇÃO DE UM MODELO DE PROGRAMAÇÃO RECURSIVA AO ESTUDO DO CRESCIMENTO DA PRODUÇÃO AGRÍCOLA NA REGIĀO DE CAMPINAS, ESTADO DE SÃO PAULO, 1970/71 A 1976/77
}

ANTONIO CELSO GEMENTE

Orientador: FERNANDO CURI PERES

Dissertação apresentada à Escola Superior de Agricultura "Luiz de Queiroz" da Universidade de São Paulo, para obtenção do titulo de Mestre em Economia Agrária.

PIRACICAB A

Estado de São Paulo - Brasil setembro, 1978 
ii.

A meus pais 


\section{AGRADECIMENTOS}

A Empresa Brasileira de Pesquisa Agropecuária (EMBRAPA), pela oportunidade oferecida de frequentar o Curso de Pös-Graduação.

Ao Instituto de Economia Agrícola do Estado de São Paulo (IEA), que forneceu a maior parte dos dados utilizados neste traba1ho, além do suporte financeiro através do Projeto "Projeção e Planejamento do Desenvolvimento Agrícola do Estado de São Paulo".

Ao Professor Fernando Curi Peres, pela valiosa orientação oferecida durante toda a fase de desenvolvimento do trabalho.

Aos Professores José Ferreira de Noronha e Rodolfo Hoffmann, pela leitura dos originais, contribuindo com importantes sugestōes.

Aos colegas Antonio Carlos Roessing, Luiz Antonio Pinazza e Yuly Ivete Miazaki de Toledo, que participaram da realização de grande parte deste trabalho.

A Coordenadoria de Assistêncla Técnica Integral (CATI), re presentada pelos Eng ${ }^{\circledR} \mathrm{Agr}^{\circ}$ Adibe Jorge Roston e Eng Agr ${ }^{\circ}$ Carlos Lo rena, por suas contribuições a este trabalho.

Aos colegas, professores e funcionários do Departamento de Economia e Sociologia Rural da ESALQ.

A Fundação Ford, pelo suporte financelro para a publicação deste trabalho.

A todos que, direta ou indiretamente, tenham auxiliado na realização deste trabalho. 
Pág.

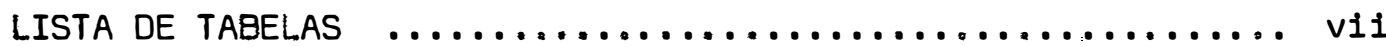

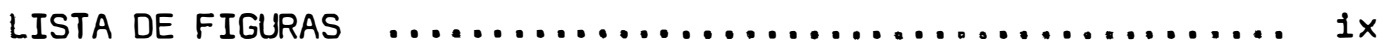

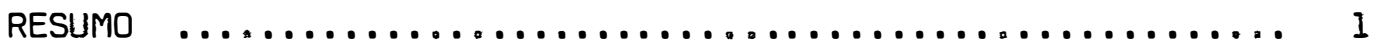

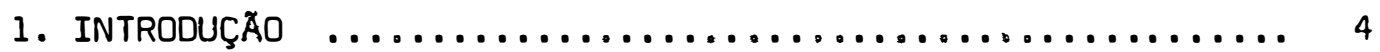

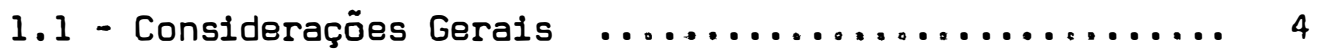

1.2 - o Problema $\ldots \ldots \ldots \ldots \ldots \ldots \ldots \ldots \ldots \ldots \ldots \ldots, 6$

1.3 - Objetivos e Pressuposições $\ldots \ldots \ldots \ldots \ldots \ldots \ldots \ldots .11$

2. CARACTERIZAÇÃ DA AREA E FONTE DE DADOS $\ldots \ldots \ldots \ldots \ldots \ldots, 14$

2.1 - A Área de Estudo ........................... 14

2.2 - História da Agricultura Paulista e Resumo das Polfti cas Recentes Para o Setor Agrícola ............ 20

2.3 - A Fonte de Dados .............................. 24

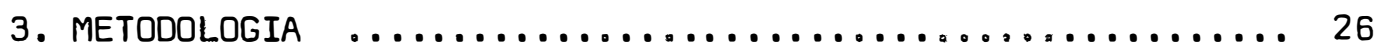

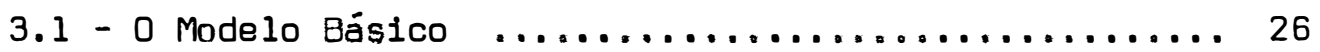

3.2 - 0 Modelo Empírico $\ldots \ldots \ldots \ldots \ldots \ldots \ldots \ldots \ldots \ldots ., 36$

3.2 .1 - As atividades $\ldots \ldots \ldots \ldots \ldots \ldots \ldots \ldots \ldots . . \ldots 6$

3.2.2 - o critério de otimização $\ldots \ldots \ldots \ldots \ldots \ldots, 47$

3.2.3 - Modelo de expectativa de preços ......... 50

3.2 .4 - 0 conjunto das equações restritivas ...... 53

3.2.4.1 - Restriçöes de terra ........... 53

3.2.4.2 - Restrições de mão-de-obra $\ldots \ldots .54$

3.2.4.3 - Restrições financeiras ........ 55 
Pàg.

3.2.4.4 - Restrições de máquinas e animais de trabalino ............. 57

3.2.4.5 - Balanço de insumos variáveis ... 58

3.2.4.6 - Balanço de produçäo, consumo e

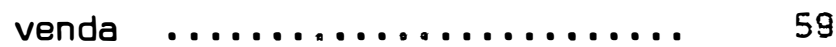

3.2.4.7 - Balanço de pasto $\ldots \ldots \ldots \ldots \ldots .60$

3.2.4.8 - Balanço das culturas perenes .. 60

3.2.4.9 - Restrições de comportamento (coe ficientes de flexibilidade) .... 60

3.2.4.10 - Restrições não-negativas .... 61

3.2 .5 - As disponibilidades (RHS) ........... 61

3.2 .5 .1 - Terra $\ldots \ldots \ldots \ldots \ldots \ldots \ldots \ldots \ldots .62$

3.2.5.2 - Mão-de-obra $\ldots \ldots \ldots \ldots \ldots \ldots .62$

3.2.5.3 - Caixa (capital de giro) ...... 65

3.2.5.4 - Crédito $\ldots \ldots \ldots \ldots \ldots \ldots \ldots \ldots 66$

3.2 .5 .5 - Máquinas $\ldots \ldots \ldots \ldots \ldots \ldots \ldots \ldots$ 6..... 67

3.2.5.6 - Animal de trabalho $\ldots \ldots \ldots \ldots .68$

3.2.5.7 - Culturas perenes $\ldots \ldots \ldots \ldots \ldots .68$

3.2.5.8 - Coeficientes de flexibilidade .. 69

3.3 - A Estratificação e Extensão do Modelo ......... 73

4. RESULTADOS E DISCUSSÃo $\ldots \ldots \ldots \ldots \ldots \ldots \ldots \ldots \ldots \ldots \ldots$

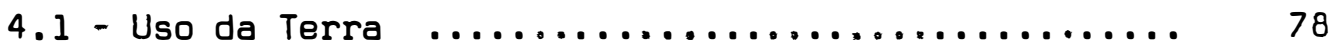

4.2 - Composição das Atividades ................ 84 
Pág.

4.2 .1 - Culturas anuais e perenes ............ 84

4.2 .2 - Pecuáría e pastagens ................. 85

4.3 - Produtividade dos Fatores de Produção .......... 89

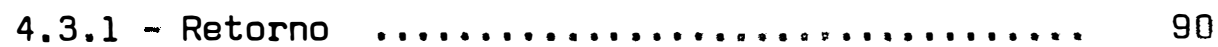

4.3 .2 - Produtividade da terra ............... 91

4.3 .3 - Produtividade do trabalho ............ 93

4.3 .4 - Produtividade do capital .............. 94

4.4 - Proporcionalidade Entre os Fatores de Produção ... 99

4.4 .1 - Trabalho e terra ................. 99

4.4 .2 - Trabalho e trator .................. 107

4.4 .3 - Animal de trabalho e outros fatores ..... 109

4.5 - Uso do Capital Financeiro ................. 113

4.6 - Retorno por Propriedade $\ldots \ldots \ldots \ldots \ldots \ldots \ldots \ldots \ldots$

4.7 - Confronto com os Dados Disponíveis ........... 119

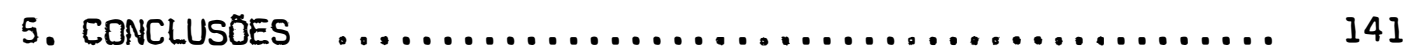

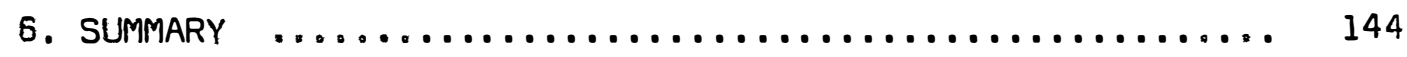

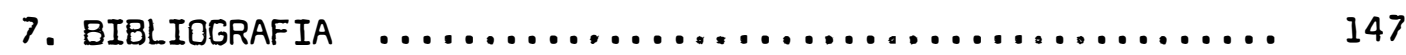

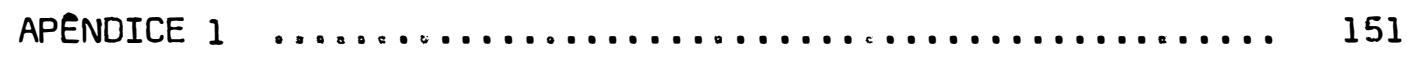

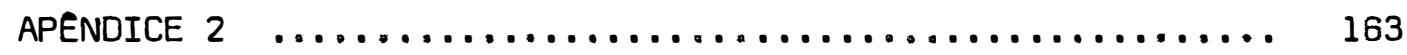

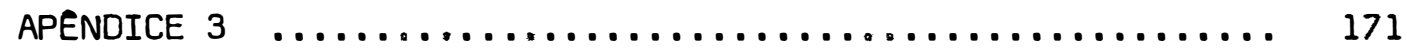


vii.

\section{LISTA DE TABELAS}

TABELA

Pág.

1 Area, em hectares, das principais culturas da DIRA de Campinas e sub-regiões $\ldots \ldots \ldots \ldots \ldots \ldots \ldots \ldots$

2 Distribulção por área, em hectares, e em porcentagem, das atividades pecuárias, florestais e algumas formações vegetais, na DIRA de Campinas e sub-

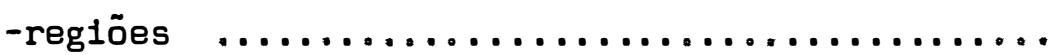

3 Terra utilizada em culturas anuais, culturas perenes, pastagens e terra total utilizada, em hectares, por estrato de área e a cada ano $\ldots . . . . .$.

4 RETORNO, em mil cruzeiros de 1970, por estrato de

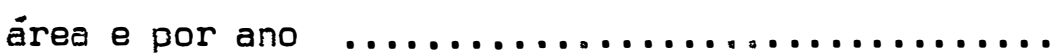

5 Produtividade da terra, em cruzeiros de 1970 por hectare de terra utilizada, por estrato de área e por ano. Produtividade do trabalho, em cruzeiros de 1970 por dias-homens empregados, por estrato de ärea e por ano. Produtividade do capital, por estrato de área e por ano $\ldots \ldots \ldots \ldots \ldots \ldots \ldots \ldots \ldots$

6 Relação TRABALHO/TERRA, em dias-homens empregados por hectare de terra utilizada, por estrato de área e por ano

7 Relação FERTILIZANTES/TERRA, em quilogramas por hec tare de terra utilizada, por estrato de área e por ano. Relação INSUMOS MODERNOS/TERRA, em cruzeiros de 1970 por hectare de terra utilizada, por estrato de área e por ano 
viii.

TABELA

Pág.

8 Relação TRABALHO/TRATOR, em dias-homens empregados por dias-máquina utilizados, por estrato de área e por ano

9 Relação ANIMAL/TERRA, em dias-animal empregados por hectare de terra utilizada, por estrato de ärea e por ano. Relação TRABALHO/ANIMAL, em dias-homens por dias-animal empregados, por estrato de área e por ano. Relação TRATOR/ANIMAL, em dias-máquina por dias-animal empregados, por estrato de área e por ano

10 Relação CAIXA/TERRA, em cruzeiros de 1970 por hectare de terra utilizada, por estrato de área e por ano

11 Distribuição média da renda, em cruzeiros de 1970 por propriedade, por estrato de área e por ano ... 117

12 Resultados do teste usado no confronto com os dados observados, para cinco culturas, por estrato de área e para a região 


\section{LISTA DE FIGURAS}

1 Localização da DIRA de Campinas no Estado de São

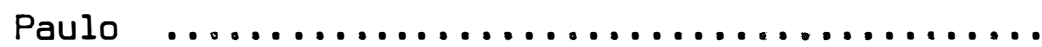

2 Aproximação de uma função de produção usual através da P.L. .......................... 28

3 Esquema geral do modelo básico, mostrando as prin cipais atividades e restrições em determinado periodo

Oferta regional de trabalhadores contratados ... 64

5 Arranjo das matrizes para a competição regional en tre os sub-agregados $\ldots \ldots \ldots \ldots \ldots \ldots \ldots . \ldots . \ldots . \ldots 77$

6 Terra utilizada em culturas anuais $\ldots . . \ldots \ldots . .$. 8?

7 Terra utilizada em culturas perenes ........ 82

8 Terra utilizada em pastagens $\ldots \ldots \ldots \ldots . \ldots . \ldots 3$

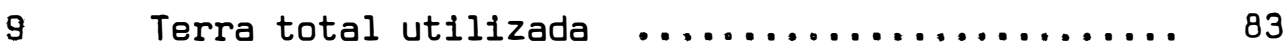

10 Indices de crescimento de pecuária bovina de cor-

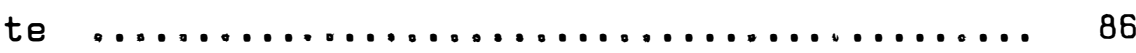

11 Indices de crescimento de pecuária de leite B .. 86

12 Indices de crescimento de pecuária de leite C .. 87

13 Indices de crescimento do RETORNO ........... 91

14 Produtividade da terra $\ldots \ldots \ldots \ldots \ldots \ldots \ldots . \ldots . \ldots 9$

15 Produtividade do trabal ho $\ldots \ldots \ldots \ldots \ldots \ldots . \ldots 9$

16 Produtividade do capital $\ldots \ldots \ldots \ldots \ldots \ldots \ldots$............ 98

17 Relação TRABALHO/TERRA $\ldots \ldots \ldots \ldots \ldots \ldots \ldots . \ldots \ldots$ 
18 Relação FERTILIZANTE/TERRA $\ldots \ldots \ldots \ldots \ldots \ldots \ldots \ldots . \ldots . \ldots . \ldots$

19 Relação INSUMOS MODERNOS/TERRA $\ldots \ldots \ldots \ldots \ldots \ldots \ldots$

20 Relação TRABALHO/TRATOR $\ldots \ldots \ldots \ldots \ldots \ldots \ldots \ldots$

21 Relação ANIMAL/TERRA $\ldots \ldots \ldots \ldots \ldots \ldots \ldots \ldots \ldots \ldots \ldots$

22 Relação TRATOR/ANIMAL $\ldots \ldots \ldots \ldots \ldots \ldots \ldots \ldots \ldots \ldots . \ldots \ldots$

23 Relação TRABALHO/ANIMAL $\ldots \ldots \ldots \ldots \ldots \ldots \ldots \ldots . \ldots \ldots$

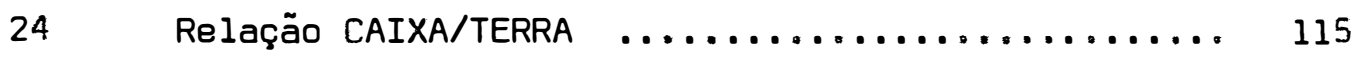

25 RETORNO/PROPRIEDADE $\ldots \ldots \ldots \ldots \ldots \ldots \ldots \ldots \ldots \ldots \ldots \ldots$

26 Indices das áreas plantadas com algodão ........ 125

27 Indices das äreas plantadas com batata da seca na

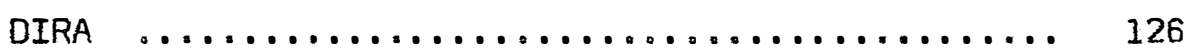

28 Indices das áreas plantadas com café .......... 127

29 Indices das āreas plantadas com feijão das águas.. 128

$30 \quad$ Indices das áreas plantadas com milho .......... 129 
RESUMO

O presente trabalho ut1liza-se de um modelo de programaçäo recursiva para reproduzir o padrão de crescimento da prod!ıção agrícola na Divisão Reglonal Agrícola (OIRA) de Campinas, Estado de São Paulo, no perfodo 1970/71 a 1976/77. Este é o seu princlpal objetivo, ao qual juntam-se dols outros: a discussão dos procedimentos complementares ao modelo básico necessários àquela repro dução, e a avallação do desempenho do modelo. Os dados ut1l1zados no trabalho foram fornecidos pelo Instituto de Economia Agrícola de São Paulo.

No capitulo de metodologla apresenta-se detalhadamen te o modelo básico e o modelo empírico. O modelo de programação recursiva usa a tëcnica de programação linear para maximizar uma funço de receita liquida das atividades agrícolas realizadas na reg:ão, sujelta a um conjunto de restrições, que traduzem as disponi- 
b111dades de recursos; trata-se de um modelo dinâmico, em que as so luções de perfodos anterlores são transferidas para o perfodo corrente através de funçōes recursivas especificas. Como extensão deste capitulo, menciona-se que as propriedades agrícolas da região fo ram divididas em três estratos de área para atender a pressuposição que cada um adota caminhos diversos de evolução devido às diferentes proporções de recursos entre eles; assume-se também que existe homogeneldade nos estratos de área, o que os possibilita a obedecerem um únı́co critērio de otimização.

Os resultados são apresentados como se segue: (a) em termos de uso da terra, verificou-se que houve flexibilidade no seu uso para culturas anuals e pastagens, enquanto terras para culturas anuals foram restritıvas; (b) na anälıse sobre as produtividades dos fatores terra, trabalho e capltal, constatou-se que os malores acrés clmos na região ocorreram nesta ordem; (c) quanto às mudanças na pro porclonalidade entre os fatores de produção, observou-se que as leves tendênclas no perfodo não conflrmam nenhuma hipötese clara a es se respelto; (d) com relação ao uso do capital financelro, verificou-se que houve excesso de liquidez no sistema; (e) no caso da dis tribulção da recelta líquida observada por propriedade,constatou-se que o grupo das grandes propriedades è nitidamente favorecido: (f) finalmente realizou-se um confronto com dados reals observados, para värlas atıvidades escolhidas, evidenciando-se que poucos ajustamentos conseguem alguma explicação, segundo o teste ut1lizado. 
No capltulo de conclusöes, admite-se que o fraco desempenho do modelo está assoclado: (a) às poucas alternativas de tecnalogia que se permitiu; (b) à ausência de competição regional; e (c) à diversidade e extensão regionais que ofereceram grandes obs táculos à simulação do crescimento da produção agrícola no perfodo. 
1. INTRODUŞÃ.

\section{1 - Considerações Gerais}

D conhecimento do setor agrícola de uma reglão, na medida em que este participa do processo através do qual se realiza - desenvolvimento da economia regional, torna-se indispensável para a anälise das causas e 1mplicações daquele processo. Neste trabalho a atenção é voltada para o caso da Divisão Regional Agrícola (DIRA) de Campinas, no perfodo que abrange os anos agrícolas de 1970/71 a $1976 / 77$.

A base de que se partiu para empreender a tarefa de compreensão do crescimento agrícola regional fol a estruturação do processo de tomada de decisões da unidade produtiva agrícola em ter mos agregados. Tentou-se a simulação de como se procedem as decisões acersa do que e quanto produzir em uma determinada região, tendo-se em conta as condlçöes Internas e externas que as influenclam. Isto 
foi realizado con o auxilio de um modelo de programação matemática que procura incorporar todos os elementos relevantes para o problema. If

O modelo de programação recursiva fol primeiramente desenvolvido por DAY (1963) e aplicado sucessivamente por HEIDHUES (1966), SINGH (1971) e AHN (1972). Trata-se de um critério de otimi zação sequencial, no qual as decisões de períodos anteriores influenciam as decisões do perfodo corrente, e assim por dlante, dentro dos limites de um horizonte de planejamento. Em cada perfodo se estabelece uma função-objetivo linear (margem bruta) a ser maximizada, sujelta a um conjunto de restrições; estas traduzem a disponibilida de dos recursos existentes. A solução conseguida se transfere para os perfodos subsequentes através de funçōes recurstvas especificas. D modelo é dinâmico (visto que consegue incorporar a varlävel tempo por melo do mecanismo recursivol, mas difere de outros modelos de programação dinâmica que assumem um único critério de otimização abrangendo todo o horłzonte de planejamento. Dessa ma. neira, o modelo recursivo pode trabalhar com bastante flexibilidade, permitindo ajustamentos perfodo a período $e$, portanto, com possibilidade de reverter expectativas, procedimento que parece melhor aproximar-se do processo de tomada de decisões. Em contrapartida, es barra em problemas como o do plano de investimentos, já que não dis

I/ O presente trabalio Integra um projeto amplo de análise do comportamento do setor agrícola de São Paulo, a cargo do Instituto de Economia Agrícola da Secretarla de Agricultura do Estado de Säo Paulo. 
pöe de um horlzonte que 1gual1ze adequadamente as oportunidades pre sentes e futuras.

Os estabelecimentos agropecuários da região foram classificados em três estratos de ärea, representando as propriedades pequena, médla e grande. As matrizes tecnológlcas obedecem a 11 gelras varlaçöes para atender a essa estratificação;o componente que as diferenclam de fato sāo as diferentes disponibilidades de recursos entre os estratos. Paralelamente à construçäo das matrizes faz-se uso de um modelo simples de expectativa dos preços dos produ tos agrícolas, cujos preços rea1s defasados de um ano foram inflaclonados para acompanhar melhor o comportamento dos produtores numa economía Inflacionáría como a brasileira.

Para o primelro perfodo de funcionamento do modelo säo necessárlos dados sobre a região que forneçam o suporte para o cálculo dos coeficlentes técnicos e da capacidade disponf́vel. Os da dos de perfodos posterlores servirão para testar o modelo na sua eficlêncla em reproduzir a histórla da agricultura regional.

\section{2 - O Problema}

As tentativas de entender o desenvolvimento agricola fazem-se, necessarlamente, Integrando-o no concelto geral de desenvolvimento que diversas teorlas buscam explicar. Mas as teorlas desenvolvimentistas, por sua própria natureza, têm que tratar comgran des generalizaçōes, e comumente assumem a forma de anälises qualita tıvas; nestas, apenas as variäve1s económicas julgadas ma1s 1mpor- 
tantes são cons1deradas, com elevado grau de abstração. A formal1za ção quant1tatıva do problema nem sempre é possfvel ou desejável dada a sua complexidade. Exemplos clássicos de esforços nesse sentido säo o modelo de crescimento de VON NEUMANN (1945) e a análise inter setorial efetuada por LEONTIEF (1953) nos modelos de insumo-produto, ambos concorrendo para o desenvolvimento das técnicas de programação matemätica.

0 modo pelo qual se realiza a transformaçāo na agrıcultura assume importàncla que se faz sent1r conforme o estáglo geral de desenvolvimento dos pafses. Segundo HAYAMI e RUTTAN(1971), o desenvolvimento é obtido quando se realiza a melhor escolha para o processo de mudança tecnológica na agricultura, em função dos recur sos disponfveis. Isto é particularmente de interesse no caso de paf ses menos desenvolvidos em que, via de regra, a agricultura é o setor tradicional da economia. Nesses palses o desempentio da agricultura tem ma1or relevo pela quant1dade de recursos af empregados, e também pela responsabilidade de gerar porção considerável da renda e divisas nacionais. A medida que o grau de desenvolvimento é maior, a Importàncla relativa da agricultura tende a diminuir, embora seu papel durante e após as fases ma1s intensas das mudanças na economia, seja quase sempre decisivo.

0 Brasil conta com um parque industrial de porte, ao lado de um setor de serviços em expansão, mas existem disparidades regiona1s e intersetorla1s na economia brasileira. A diferença entre a agricultura praticada no Sul - Sudeste e no Norte - Nordeste, 
por exemplo, é grande em favor daquela; neste amblente diferenclado parece claro que devam existir traços distintivos entre o esquema de desenvolvimento de ambas. Contribuições no sentido de esclarecer al guns aspectos de um ou outro tipo podem servir para compreendê-los melhor.

o mecanismo de preços è o principal componente que age sobre as decisões na esfera econömica, mas não é absolutamente o único. No caso da agricultura de pafses subdesenvolvidos, por exemplo, o agricultor nas regiōes mals atrasadas ou distantes lou mant1 do marginalizado nas regiōes mals desenvolvidas) condiclona-se à sub sistêncla. Isso leva, mesmo quando não se caracterizam casos extremos, às seguintes consequênclas: (a) o objetivo de persegulção de lucro máximo não é critério absoluto no processo de decisão; (b) os Incentivos de mercado não obtem pronta resposta; e (c) as polfticas orlentadas para o setor podem sofrer distorçōes nos seus resultados em relação aos objetivos originais.

Mesmo abstraindo-se do condicionamento primordial à subsistêncla na agricultura mals atrasada, alnda existem razões pon deráveis que explicam as mudanças geralmente lentas na agricultura. Sabe-se que esse setor abriga possibilidades de frustrações, que au mentam a incerteza das atividades realizadas, mais que em outros se tores. Por esta razão a composição das atıvidades agrícolas tendem à diversificação e não à especlalização, salvo poucas exceçōes. A unidade de produção na agricultura é a firma de multos produtos, os quals concorrem entre si pelos recursos comuns disponf́veis. Em al- 
guns segmentos da agricultura existe a contrapartida da unidade de consumo que se constitul na familia do proprietário e seus dependen tes. Essas interdependēnclas que se estabelecem entro os produtos que usam os mesmos insumos, e eventualmente entre consumo e renda, dão características especiais às atividades econômicas, principalmen te quando se focaliza a oferta de produtos agrícolas. DAY (1963) en fatiza que as equações de oferta dos modelos econométricos com dados de séries temporais não consideram esses aspectos importantes porque são relativamente poucas as variáveis independentes que os integram.

A elasticidade da oferta reflete, entre outras coisas, a tecnologia empregada. A adoção de novas tecnologias, principalmente a mecānica, Implica normalmente em grandes inversões que podem se tornar antieconômicas face à rápida e constante variação nos preços relativos dos produtos, e dos insumes tradicionais e modernos, em confronto com a lenta desincompatibilização ou especificidade da nova tecnologia tornada antieconômica.

Uma tentativa de considerar todos esses aspectos importantes é o modelo de defasagem distribuida no tempo de NERLOVE (1958), que trabalha com os fatores incerteza e/ou rigidez nos ajus tamentos das forças de oferta e demanda no curto e longo prazos. De forma semelhante procede o modelo de Henderson de utilização da ter ra (para oferta no curto prazo), do qual o modelo de programação re cursiva é derivado diretamente. 
Na unidade de produção agrícola dols componentes básicos atuam simultaneamente. D primeiro refere-se às condiçōes internas da empresa que se traduz nas suas disponibilidades de recursos. Mudanças nessas disponibilidades alteram a proporção entre os fatores de produção e, portanto, a tecnologia. 0 segundo desses com ponentes diz respeito às condiçōes externas onde existem a compet1çäo por recursos e a presença institucional na forma de polf́ticas orientadas para o setor agrícola e os dispositivos legais. Este último Incide sobre todas as unidades de produção, ao passo que a com petição por recursos e a sua disponıbilidade interna podem levar a que se distinguam numa mesma região agregados que se comportam de modo diferenciado.

DAY (1963) sumariza o confunto de forças que atuamna unidade de produção agrícola dizendo que "um modelo adequado de pro dução deveria incluir pelo menos as seguintes:

(a) a interdependência de produtos que usam insumos comuns;

(b) ajustamento no tempo;

(c) mudança tecnológica;

(d) ação polftica planejada;

(e) mudanças nos componentes ärea e rendimentos das atividades produtivas;

(f) incerteza;

(g) demanda, oferta e interaçōes de preços;

(h) oferta agregada de fatores de produção; 
(1) taxas de Investimento em fatores fixos no curto prazo; e

(1) especlalização regional e competição."

A eficiêncla na alocação de recursos, a capacidade de gerar empregos, a demanda por fatores não agrícolas e a oferta de produtos agrícolas, o impacto de políticas como o crédito rural,pre ços mínimos, e subsídios a insumos modernos, formação e utilização de capital, e o uso da terra, entre outros, são alguns pontos que Interessam na avaliação do desempenho do setor agrícola. Os problemas no tratamento desse tema referem-se ao trabalho de coleta e levantamento dos dados necessários, e a forma pela qual se podería en. volver todas as variáveis relevantes sem perda de sua generalidade e precisão.

0 modelo recursivo parece potencialmente poder captar todas aquelas forças económicas mencionadas há pouco que incidem sobre os centros de decisão, desde que se disponha das informaçōes necessárias. Os resultados a que chegaram outros autores no uso do modelo de programação recursiva, juntamente com as possibilidades de que é dotado, permitiam prever sua escolha como satisfatória para os objetivos que se tinha em mente.

\section{3 - Objetivos e Pressuposiçōes}

Os objetivos deste estudo são os seguintes:

(a) elaborar um modelo de programação recursiva capaz de repro duzir o padrão de evolução da produção agrícola de uma região durante determinado período: 
(b) discutir os procedimentas complementares ao modelo básico necessártos a esta reprodução;

(c) avaliar o desempento do modelo na reprodução daquela evolu ção.

0 estudo não persegue nenhum outro objetivo especif 1 co entre os que potenclalmente permite o modelo, mas estudos adicio nals de simulação ou projeçōes podem ser feitas com base na sua estrutura. 21

A pressuposição básica do trabalho é de que as decisöes das unidades produtivas agrícolas obedecem a um critério ünico que representa o agregado das decisões individuais efetivamente rea Iizadas.

Visto que dificilmente se pode fazer esta pressuposi cão para toda a região, 1sto é transposto para os sub-agregados dis postos em termos de estratos de área segundo o tamanho das propriedades. Nestes, a pressuposição é que cada um escolhe caminhos diversos no esquema produtivo que resultam de diferentes proporçōes en tre seus recursos disponfveis.

As decisões de todos os estratos de ärea podem ser no vamente agregadas caso se proceda à competição por recursos regionais usando uma tëcnica simples de partição de matrizes. Neste estú do, no entanto, näo se procede desse modo, sendo o agregado regional

2/ Os trabalhos de SINGH (1971) e AHN (1972) contèn referências ex plfcitas a esse respeito. 
simplesmente o somatório dos valores obtidos nos estrados de área escolnidos. 


\section{CARACTERIZAÇĀO DA ÁREA E FONTE DE DADOS}

\section{1 - A Area de Estudo}

A Divisão Regional Agrílcola (DIRA) de Campinas abran ge uma ärea geogräfica de aproximadamente 2.300 .000 hectares, localizada numa falxa de terra mais ou menos na porção Centro-Nordeste do Estado de São Paulo, conforme mostra a Figura 1.

As DIRAs do Estado de São Paulo originaram-se de pequenas modificaçōes efetuadas no trabalino de divisão administrativa do Estado posto em prática a partir de 1967. De acordo com VOLLET (1974, p. 35): "A equipe técnica da Secretarla de Economia e Planejamento, que elaborou o modelo de regionalização, adotou o critério de polarização urbana, ou seja, a Integração de alguns centros em torno de polos urbanos (cidades), que satisfizessem certas exigênclas no sentido de serem um foco de atração para esses centros". 


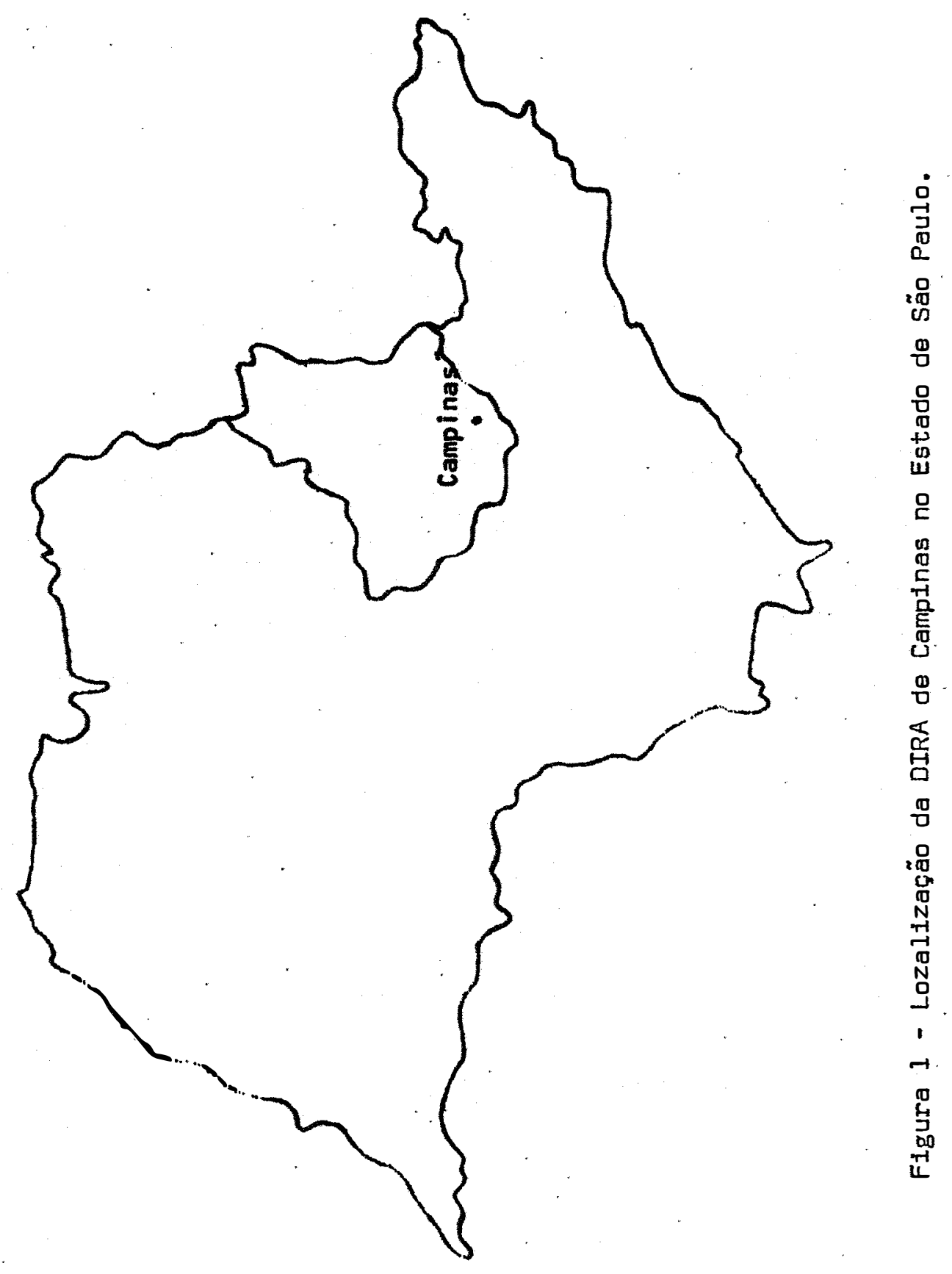


A DIRA de Campinas conta com 67 municfpios distribuf dos por 6 sub-regiões que levam o nome da cidade sede:

1. Sub-reg1ão de Campinas;

2. Sub-região de Casa Branca;

3. Sub-região de Limeira;

4. Sub-região de Piracicaba;

5. Sub-região de Rio Claro;

6. Sub-região de São João da Boa Vista.

Duas particularidades com respelto à região escolhida para o estudo merecem atenção: a posição geogräfica e econōmica privilegiadas que the assegura alto grau de desenvolvimento, e sua extensão territorial, ambas concorrendo para a grande diversificação de atividades. A proximidade com o maior centro industrial do pars - a área metropolitana do grande São Paulo - e contendo em seus próprios limites outros centros também bastante desenvolvidos, fazem-na uma região progressista.

A despeito da diversificação da região, que abrange grande heterogeneidade de solos, de topografla e de composlção das atividades agropecuárias, o trabalho de VOLLET (1974) mantém quatro das sels sub-regiões atuals ainda agrupadas, incluindo uma outra quin ta, contudo em função apenas do critério de contiguidade geográfica; as sub-regiões exclufdas foram as de Plracicaba e Rio Claro. 0 autor conclu1 que nas sub-regiões finalmente agrupadas são escassas as pro priedades rurais com grandes áreas, com predominâncla de culturas 
permanentes, de pastagens natura1s, de rebanhos bovinos de le1te, e elevada porcentagem de área cultıvada em relação à área total.

Na sub-região de P1racicaba se destaca a cultura da cana-de-açúcar e a bovinocultura de corte, enquanto na sub-região de Rio Claro a cana e o reflorestamento são predominantes. Já na subreg1ão de Campinas é característico a produção em pequenas propriedades do tipo empresa famlliar como as de produtos hortigrangeiros, Inclusive com uma Importante zona de fruticultura temperada. E também bacla le1telra considerável em confunto com a sub-região de Casa Branca (Mococa) que, além do le1te, possu1 zonas especlalizadas em batata e cebola. Na sub-região de Limeira predomina a cultura de cltrus e São João da Boa Vista é a sub-reg1ão menos caracterizada, mas onde se destacam o café, milho, algodão, e a batata, além de atıvidades pecuárias e florestais.

As principals atividades agropecuárlas da DIRA de Cam plnas e das sub-regiöes são mostradas nas Tabelas 1 e 2. 
Tabela 1 - Area, em hectares, des principals culturas de DIRA de Can pinas a sub-regiōes.

\begin{tabular}{|c|c|c|c|c|c|c|c|}
\hline \multirow{2}{*}{ CULTURAs } & \multicolumn{7}{|c|}{ DrRA de Campinas Sub-Regicos } \\
\hline & DRA & Compinas & $\begin{array}{c}\text { Casa } \\
\text { Branea }\end{array}$ & Linetra & Plract & $\begin{array}{l}\text { Pdo } \\
\text { Clero }\end{array}$ & $\begin{array}{l}\text { S.J. de } \\
\text { bon vis } \\
\text { ta }\end{array}$ \\
\hline $\begin{array}{l}\text { Som das oreas das prin. } \\
\text { ofpole cultures }\end{array}$ & 722.528 & 79.302 & 108.100 & 192.543 & 278.928 & 55.757 & 88.878 \\
\hline Caf: & $\begin{array}{l}58,340 \\
(7,91)^{\circ}\end{array}$ & $\begin{array}{r}12.385 \\
(15,58)\end{array}$ & $\begin{array}{r}22.795 \\
(21,09)\end{array}$ & $\begin{array}{r}3.557 \\
(0,81)\end{array}$ & $\begin{array}{r}713 \\
(0,40)\end{array}$ & $\begin{array}{r}4.398 \\
\{7.89\}\end{array}$ & $\begin{array}{r}14,512 \\
(14,88)\end{array}$ \\
\hline Cana pare Induístria & $\begin{array}{l}272.068 \\
(38.18)\end{array}$ & $\begin{array}{r}10.710 \\
(13,51\}\end{array}$ & $\begin{array}{r}14,850 \\
(13,74)\end{array}$ & $\begin{array}{r}88.842 \\
(35.94)\end{array}$ & $\begin{array}{l}137.224 \\
(78,89)\end{array}$ & $\begin{array}{r}23.878 \\
(42.83)\end{array}$ & $\begin{array}{r}18.562 \\
(16.75)\end{array}$ \\
\hline Cona pare Forragem & $\begin{array}{r}8.911 \\
(1.25)\end{array}$ & $\begin{array}{l}1.566 \\
(1,97)\end{array}$ & $\begin{array}{r}2.088 \\
(1.93)\end{array}$ & $\begin{array}{r}3.149 \\
(0.80)\end{array}$ & $\begin{array}{r}1.230 \\
(0,69)\end{array}$ & $\begin{array}{r}1.400 \\
(2.52)\end{array}$ & $\begin{array}{l}1.480 \\
(1,50)\end{array}$ \\
\hline nilno & $\begin{array}{l}132.182 \\
(18,55)\end{array}$ & $\begin{array}{r}28.918 \\
(38.46)\end{array}$ & $\begin{array}{r}32.858 \\
(30,40)\end{array}$ & $\begin{array}{r}19.430 \\
(10.34)\end{array}$ & $\begin{array}{l}17.046 \\
(9.53)\end{array}$ & $\begin{array}{r}13.325 \\
(23,88)\end{array}$ & $\begin{array}{r}20.617 \\
(20,85)\end{array}$ \\
\hline Algodio & $\begin{array}{r}76.588 \\
(30.75)\end{array}$ & $\begin{array}{r}31.322 \\
(14.28)\end{array}$ & $\begin{array}{r}8.041 \\
(8,38)\end{array}$ & $\begin{array}{r}31.746 \\
(16,57)\end{array}$ & $\begin{array}{r}5.400 \\
(3.02\}\end{array}$ & $\begin{array}{r}706 \\
(1,27)\end{array}$ & $\begin{array}{r}18,383 \\
(18,57)\end{array}$ \\
\hline Amendosin des Aruas & $\begin{array}{r}735 \\
(0,20)\end{array}$ & $(0,05)^{41}$ & $(0.08)$ & $\begin{array}{r}296 \\
(0,15)\end{array}$ & $\begin{array}{r}97 \\
(0,05)\end{array}$ & $\begin{array}{r}113 \\
(0,20)\end{array}$ & $\begin{array}{r}80 \\
(0,09)\end{array}$ \\
\hline Amandols de sece & $\begin{array}{r}140 \\
(0,02)\end{array}$ & $(0,01)^{4}$ & $(0,05)$ & $\begin{array}{r}83 \\
(0,033\end{array}$ & $(0,01)$ & - & $(6,01)^{7}$ \\
\hline Laranja & $\begin{array}{r}82.461 \\
(11.57)\end{array}$ & $\begin{array}{l}6.434 \\
(8.11)\end{array}$ & $\begin{array}{r}3.248 \\
(3.00)\end{array}$ & $\begin{array}{r}53.853 \\
(28,12)\end{array}$ & $\begin{array}{r}4,220 \\
(2,38)\end{array}$ & $\begin{array}{r}4.378 \\
\{7.85\}\end{array}$ & $\begin{array}{r}10.328 \\
(10,45)\end{array}$ \\
\hline Arroz & $\begin{array}{l}12.543 \\
\{5.97\}\end{array}$ & $\begin{array}{r}3.753 \\
(4.73)\end{array}$ & $\begin{array}{r}9.647 \\
(8 ; 92)\end{array}$ & $\begin{array}{r}3.014 \\
(4,18)\end{array}$ & $\begin{array}{r}7,489 \\
(4,19)\end{array}$ & $\begin{array}{r}5.663 \\
(20,26)\end{array}$ & $\begin{array}{r}7.977 \\
(8,07)\end{array}$ \\
\hline Manditoce & $\begin{array}{l}19.203 \\
(2.71)\end{array}$ & $\begin{array}{r}660 \\
(0.83)\end{array}$ & $\begin{array}{r}3.028 \\
(2,80)\end{array}$ & $\begin{array}{r}5.225 \\
\{2.73\}\end{array}$ & $\begin{array}{r}3.169 \\
(1.77)\end{array}$ & $\left(\frac{1.300}{3,35)}\right.$ & $\begin{array}{r}5.893 \\
(5,96)\end{array}$ \\
\hline Batate das Kavas & $\begin{array}{r}7.489 \\
(1.05)\end{array}$ & $\begin{array}{r}345 \\
(0,44)\end{array}$ & $\begin{array}{r}5.263 \\
(4.87)\end{array}$ & {$[0.02\}$} & $\begin{array}{r}140 \\
(0,08)\end{array}$ & $\begin{array}{r}151 \\
(0,27)\end{array}$ & $\begin{array}{r}1.550 \\
(1.57)\end{array}$ \\
\hline Batate da Sece. & $\begin{array}{r}3.088 \\
10.491\end{array}$ & $\begin{array}{r}322 \\
(0,41)\end{array}$ & $\begin{array}{r}1.771 \\
(1.64)\end{array}$ & - & $\begin{array}{r}119 \\
(0,07)\end{array}$ & $(0,02)^{8}$ & $\begin{array}{r}868 \\
(0,88)\end{array}$ \\
\hline Batata de Inverno & $\begin{array}{l}1.636 \\
(0.23)\end{array}$ & $\begin{array}{r}323 \\
(0,39)\end{array}$ & $\begin{array}{r}514 \\
(0,48)\end{array}$ & $(0,02)$ & $(0,0)^{6}$ & - & $\begin{array}{r}770 \\
(0,78)\end{array}$ \\
\hline Tonete Envarado & $\begin{array}{r}1.650 \\
(0.23)\end{array}$ & $\begin{array}{r}9377 \\
(1.23)\end{array}$ & $\begin{array}{r}47 \\
(0,04)\end{array}$ & $\begin{array}{r}154 \\
(0,08)\end{array}$ & $\begin{array}{r}381 \\
(0,21)\end{array}$ & $(0,00)^{2}$ & $\begin{array}{r}89 \\
(0,09)\end{array}$ \\
\hline Tomote Rastadro & $(0.00)$ & $(0,01)^{4}$ & - & $(0,00)^{4}$ & - & - & - \\
\hline Fe1jöo des Aguas & $\begin{array}{r}8.685 \\
(1,22)\end{array}$ & $\begin{array}{r}2.037 \\
(2,54)\end{array}$ & $\begin{array}{r}1.556 \\
(1.44)\end{array}$ & $\begin{array}{r}1.409 \\
(0.74)\end{array}$ & $\begin{array}{r}1.860 \\
(1,04)\end{array}$ & $\begin{array}{r}517 \\
(0.93)\end{array}$ & $\begin{array}{l}1.306 \\
(1,32)\end{array}$ \\
\hline FeljJẼ da sece & $\begin{array}{r}9.476 \\
(1,33)\end{array}$ & $\begin{array}{r}1.318 \\
(1,66)\end{array}$ & $\begin{array}{r}3.993 \\
(3,64)\end{array}$ & $\begin{array}{r}1.273 \\
(0.81\}\end{array}$ & $\begin{array}{r}1.794 \\
\{1,00\}\end{array}$ & $\begin{array}{r}693 \\
\{1.24\}\end{array}$ & $\begin{array}{r}565 \\
(0,57)\end{array}$ \\
\hline Banana & $\begin{array}{r}553 \\
(0.08)\end{array}$ & $\begin{array}{r}251 \\
(0,32)\end{array}$ & $\begin{array}{r}26 \\
(0.02)\end{array}$ & $\begin{array}{r}31 \\
(0,02)\end{array}$ & $\begin{array}{r}84 \\
(0,05)\end{array}$ & $(0,01)^{5}$ & $\begin{array}{r}158 \\
(0,16)\end{array}$ \\
\hline Soje & $\begin{array}{r}4.019 \\
(0,56)\end{array}$ & $\begin{array}{r}631 \\
(0,80)\end{array}$ & $\begin{array}{r}1.772 \\
(1.64)\end{array}$ & $\begin{array}{r}299 \\
(0,16)\end{array}$ & - & 一 & $\begin{array}{r}1.317 \\
(1,33)\end{array}$ \\
\hline Cabolo & $\begin{array}{r}3.220 \\
(0.45)\end{array}$ & $\begin{array}{r}79 \\
(0.10)\end{array}$ & $\begin{array}{r}2.942 \\
(2,72)\end{array}$ & $(0 ; 00)^{3}$ & $(0,03)^{49}$ & $(0,01)^{3}$ & $(0,15)$ \\
\hline
\end{tabular}

FonTE; Zoneamento Agrícola do Estado de Säo Paulo, IEA, 1974.

(a) Os nímeros entra parénteses referentse ì porcentagem en relacão ò ärea totel na DIRA sub-ragióes. 
Tabela 2 - Distribuição por ärea, em hectares, e em porcentagem, das atividades pecuárias, florestais e algumas formaçöes vegeta1s, na DIRA de Campinas a sub-regiōes.

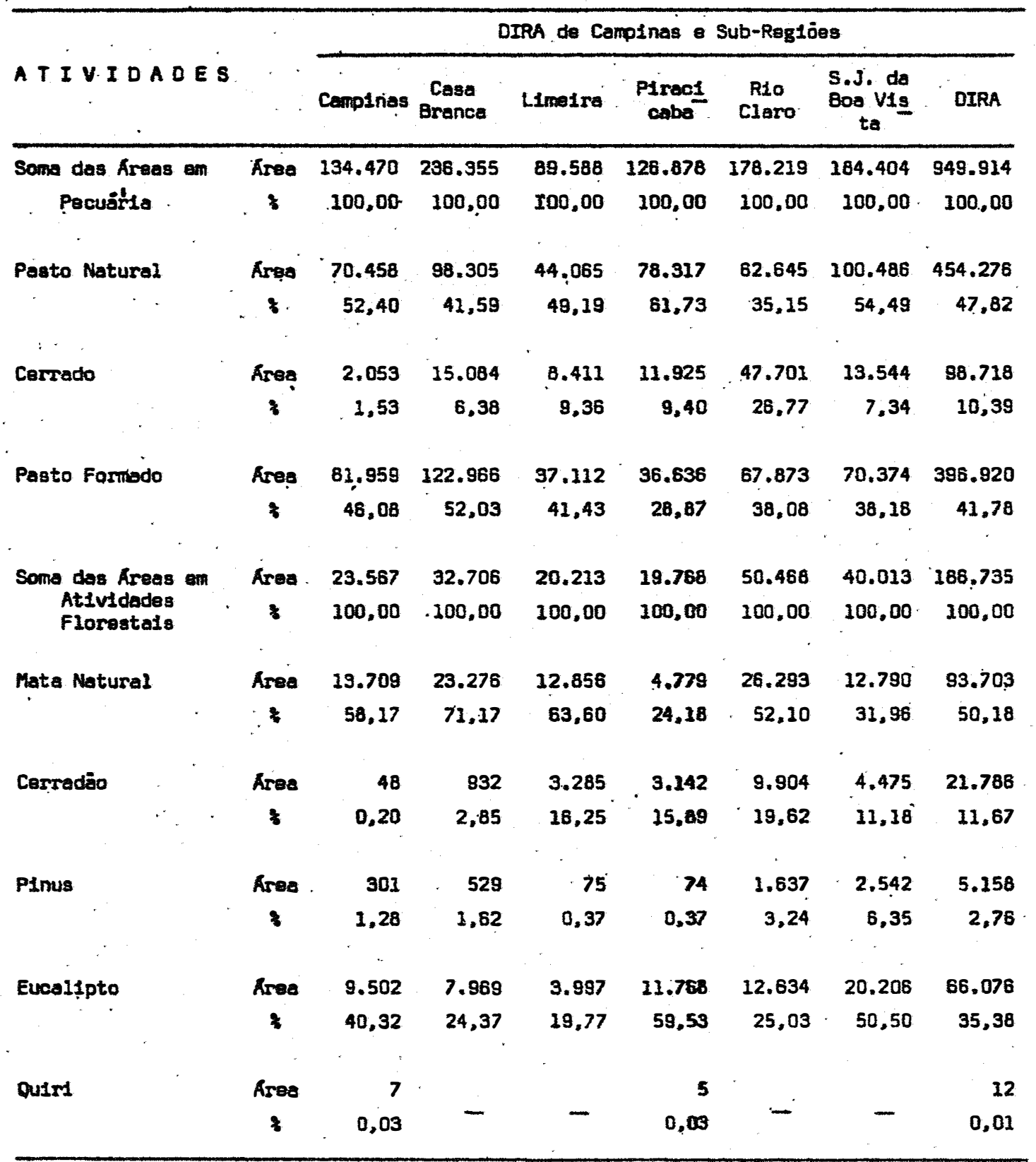

FONTE: Zonsemento Agrícola do Estado de Säo Paulo, IEA, 1974. 


\section{2 - História da Agricultura Paulista e Resumo das Políticas Re centes Para o Setor Agrícola}

Em linhas gerais, o desenvolvimento histórico da agri cultura em São Paulo alcança importâncla com o advento da cultura cafeelra por volta da última metade do século XIX, vinda do Estado do Rio de Jansiro através do Vale do Parafba, e daf passando às ter ras novas a melhores do Planalto Atlântico em direção ao oeste do Es tado de São Paulo. O ano de 1929 assinala a derrocada da economia cafeeira em vista da queda vertiginosa das cotaçōes gerais na Bolsa de Valores de Nova York. Mas simultaneamente muitos fatos novos haviam modificado o panorama da economia desde o surgimento do café: a abolição da escravatura, a imigração estrangeira, a proclamação da República, a I. Grande Guerra e outros acontecimentos em sequência desembocaram no fim da década de vinte para encontrar o ambiente so clal inteiramente transformado. A industrialização ganhara corpo, a população urbana aumentara de nümero e importância, e o setor rural volta-se para atender à demanda das cidades, em meio à desvalorização das terras e à crise externa. 3 '

O esfacelamento do sistema de colonato que fá andara desarticulado com a progressão do café para áreas mais afastadas, a ascenção do Imigrante italiano e a recente Imigração japonesa, foram os fatores conjugados que influenciaram o aparecimento de peque

3/ Este histórico apresentado baseia-se em grande parte no texto cor respondente do volume "Desenvolvimento da Agricultura Paulista", IEA, 1971. 
nas e médias propriedades com sentido comercial nas zonas próximas aos grandes centros urbanos da época. As produções de subsistência e a parceria vão sendo progressivamente marginalizadas ou virtualmente afastadas para locais cada vez mais distantes ou estagnados. Segue-se um perfodo de diversificação agrícola que se estende até a II: Guerra Mundial, em que ocorre grande desenvolvimento da cultura algodoeira ao lado de mudanças polfticas que for talecem o governo central passando este a intervir diretamente em muitos setores da economia, inclusive a agricultura. No decorrer da guerra, toma impulso no Estado a produção de açúcar e álcool, em fun ção das dificuldades do comércío com o Nordeste brasileiro, o produ tor tradicional de cana-de-açúcar. Após o fim da guerra, impulsiona do pelo recente surto de industrialização e pela obtenção de divisas através da venda dos estoques armazenados dos produtos exportáveis, o pals continua aceleradamente o processo de substituição de importações com crescimento industrial, e enfrenta as primeiras cri ses de abastecimento urbano e alta geral dos preços. Data desta épo ca a valorização dos produtos de consumo interno como o amendoim, o milho e o arroz, juntamente com os hortigranjeiros.

Na década de 50 intensificam-se os instrumentos de apoio à industrialização - como a manipulação de taxas cambiais,im postos sobre produtos agrícolas de exportação - ao mesmo tempo em que recrudesce o processo inflacionário. As medidas então tomadas fạ vorecem nitidamente as áreas urbanas com a agricultura envolvida em taxaçōes e tabelamentos. Não obstante, o café fora parcialmente rea 
bilitado (com mais intensidade fora do Estado de São Paulo) pelaboa cotação internacional no início da década, a cana-de-açücar produzi da na região suplantava a produção nordestina, e o milho aumentava de produtividade com a difusão de sementes híbridas, ao passo que as culturas alimentfcias e tradicionais sofriam decréscimos de produti vidade devido à falta de incentivos e ao controle de preços. A pecuária se solidifica, em parte devido a que a compra de terras fun ciona como reserva de valor face à inflação crescente.

O Início dos anos 60 é marcado por agitações sociais e politicas que resultam no estabelecimento de um novo regime a par tir de 1964.

A polftica oficial em relação à agricultura nos anos recentes formam um conjunto de medidas pouco mais que imediatistas, que não apontam para uma direção definida, antes atendem a necessidades ditadas por contingências do momento. Em parte, ainda se mantém a orientação praticada no auge do perfodo de substituição de im portações (1955-61) de privilégio ao setor urbano a expensas da agricultura, mas com algumas mudanças.

A agricultura de exportação, por exemplo, recebeu in centivos, enquanto se persiste no congelamento de preços dos produtos alimentares básicos. Os anos que se seguiram à mudança do regime,até por volta de 1967/68, foram de busca da estabilização polftí ca e luta contra inflação em que a agricultura tradicional de alimentos sofreu rígido controle governamental. 
A partir de 1969, por um perfodo que se estendeu até 1972/73, o Brasil conheceu um perfodo de euforla com taxas de crescimento elevadas, exportações crescentes e com a inflação em declfnio por causa da austeridade praticada durante os primeiros anos do novo regime. Essa situação sofre inflexão a partir de 1974/75. Nesse intervalo, as polfticas para o setor agrícola podem ser resumidas em:

(a) Incentivos à exportação dos produtos agrícolas que contavam com boa perspectiva no comércio internacional (exemplo: taxas de câmbio mals realistas, Isenção de alguns impostos sobre exportação, etc. );

(b) controle de preços de produtos destinados ao mercado inter no (exemplo: tabelamento de alimentos);

(c) Incentivos gerais (exemplo: crédito agrícola subsidiado,ga rantia de preços mínimos, subsidios diretos ao uso de insumos moder nos, incentivos fiscais, etc.).

As polfticas acima não foram aplicadas sistematicamente durante o perfodo. Assim, os incentivos fiscais contemplaram apenas algumas regiões como a Amazónia, Nordeste, e outras, com resultados ainda não totalmente avaliados; a 1senção de Impostos sobre exportações oscilam de produto a produto, e conforme a época; a garantia de preços mínimos, na maloria dos casos revela-se incapaz de cumprir sua função como suporte da produção: os subsídios têm si do criticados pelo seu paternalismo e discriminação em favor de gru 
pos de médios e grandes proprietärios: e os tabelamentos de produtos básicos têm com frequência obrigado à importação de produtos de fora do pals para normalizar o abastecimento.

Em conpensação, nas regiões e para os produtores que têm acesso aos benefícios da polftica agrícola (cujo núcleo é o cré dito agrícola subsidiado), constata-se o incremento da produtividade sm função do uso maciço principalmente de fertilizantes e maquinarla agrícola. E o caso da soja e da cana-de-açūcar no sul e sudes te, que contaram ainda com excelentes condições no mercado externo. O café, após a polftica de erradiação durante os anos 60 recebeu no vo ànimo recentemente; o trigo não conseguiu a meta desejada, apesar de ser talvez o único produto com preço mínimo sistematicamente aci ma dos custos de produção por ocasião da colheita; e a pecuáría está quase estagnada na criação extensiva com baixo fndice tecnológico.

O quadro descrito é bastante geral, e naturalmente a região em estudo possui particularidades que a distingue do caso bra sileiro como um todo.

\section{3 - A Fonte de Dados}

A fonte básica dos dados utilizados nesse estudo foram os levantamentos estatísticos executados pelos técnicos da Coordenadoria de Assistência Técnica Integral (CATI) sob a coordenação do Instituto de Economia Agrícola (IEA), örgãos da Secretariada 
Agricultura do Estado de São Paulo. Esses levantamentos servem para se proceder a estimativas e previsões de safras agrícolas no Estado. O preenchimento dos questionários é efetuado cinco ve zes durante o ano agrícola, nos meses de setembro, Janeiro lou feve reirol, março (ou abril), e junho, com ligeiras variações entre os mesmos para atender aos objetivos propostos. A amostragem inclui as propriedades agrícolas acima de 3 hectares, distribuidas em 12 estratos de área. As estimativas até 1973 foram obtidas de maneira a possuir erros padrões de mais ou menos $5 \%$ do seu valor, a nível de Estado: a partir de 1974 um projeto específico do IEA amplia a amos tra para obter estimativas que não apresentem erros padrões maiores que mais ou menos $10 \%$ ao nível das DIRAs do Estado de São Paulo, se gundo o trabalho de CAMPOS e PIVA (1974).

Os levantamentos são representativos para os principais produtos do Estado, mas não tratam, ou não se preocupam, com atividades demasiadamente localizadas ou com äreas especializadas, já que os objetivos são mais gerais. Também, com raras exceções (ca fé e laranja, que têm questionários especiais), a unidade de observação é a propriedade e não os produtos; estes são levantados conjuntamente.

Além desses dados primários, utilizou-se também de dados diversos presentes nas publicações do IEA, especialmente o bo letim Informações Econômicas, de edição mensal, e os Prognósticos anuais. 
26.

\section{METODOLOGIA}

\section{1 - 0 Modelo Bảsico}

!

O modelo de programação recursiva (M.P.R.) se utili-

za da técnica normal da programação linear (P.L.), na qual um critério de otimização é estabelecido para se atingir determinado obJetivo - maximização ou minimização de uma função linear - com limites impostos por um confunto de restrições. O caso que interessa imediatamente a este estudo é sua aplicação para maximizar a receita liquida esperada da unidade produtiva agrícola.

A P.L. pode ser apresentada, em termos matemäticos,

da seguinte forma:

$$
\begin{aligned}
& \text { Maximizar } \\
& \pi=z_{1} x_{1}+z_{2} x_{2}+\ldots+z_{n} x_{n},
\end{aligned}
$$

sujeito à 


$$
\begin{aligned}
& a_{11} x_{1}+a_{12} x_{2}+\ldots+a_{1 n} x_{n} \leq b_{1} \\
& a_{21} x_{1}+a_{22} x_{2}+\ldots+a_{2 n} x_{n} \leq b_{2} \\
& a_{m 1} x_{1}+a_{m 2} x_{2}+\ldots+a_{m n} x_{n} \leq b_{m}
\end{aligned}
$$

e,

$$
x_{j} \geq 0, \quad \operatorname{com} j=1,2, \ldots, n
$$

A equação (1) é a função-objetivo, com $\pi$ (margem bru ta ou receite líquida) sendo uma função linear; $x_{1}(1=1,2, \ldots, m)$ são as atividades integrantes do processo produtivo; e $z_{i}$ os coeficientes respectivos das atividades, que são constantes positivas, negativas ou nulas.

As inequações em (2) mostram os coeficientes $a_{i j}$ associados a cada atividade (variáveis $x_{1}$ ), formando uma matriz retan gular, de dimensão $m \times n$, que representa a estrutura de produção, enquanto o conjunto das constantes $b_{1}$ estabelece os limites de cada restrição.

A inequação (3) garante que se uma solução ötima existe as atividades correspondentes terão valores positivos ou nulos.

Uma função de produção, de acordo com a aproximação neo-clássica, assume a forma $y=f\left(x_{1}, x_{2}, \ldots x_{n}\right)$, em geral contí nua e diferenciävel, onde y representa a produção dependente da quan tidade utilizada dos insumos $x_{1}(1=1,2, \ldots, n)$. Num plano bi-dimensio nal, apropriado para uma apresentação simplificada, estuda-se a pro dutividade de um fator de produção mantendo-se os demais constantes: 


$$
y=f\left(x_{1} \mid x_{2}, \ldots, x_{n}\right)
$$

A P.L. assume um tipo de função de produção linear pą ra cada atividade produtiva com todas suas implicações. As mais importantes são: (a) o retorno constante à escala, e (b) a proporção fixa entre os insumos.

Essas dificuldades podem ser parcialmente superadas peio desdobramento de uma mesma atividade produtiva em quantos processos se quiser, pela mudança na proporção dos fatores. Obtem-se então a função linear "quebrada" de produção formada por processos de produção lineares que podem ser acionados simultaneamente; no li mite, se reproduz qualquer tipo de função contínua, como se observa no exemplo da Figura 2 , onde $y_{1}, y_{2}$, etc., representam os diferentes processos.

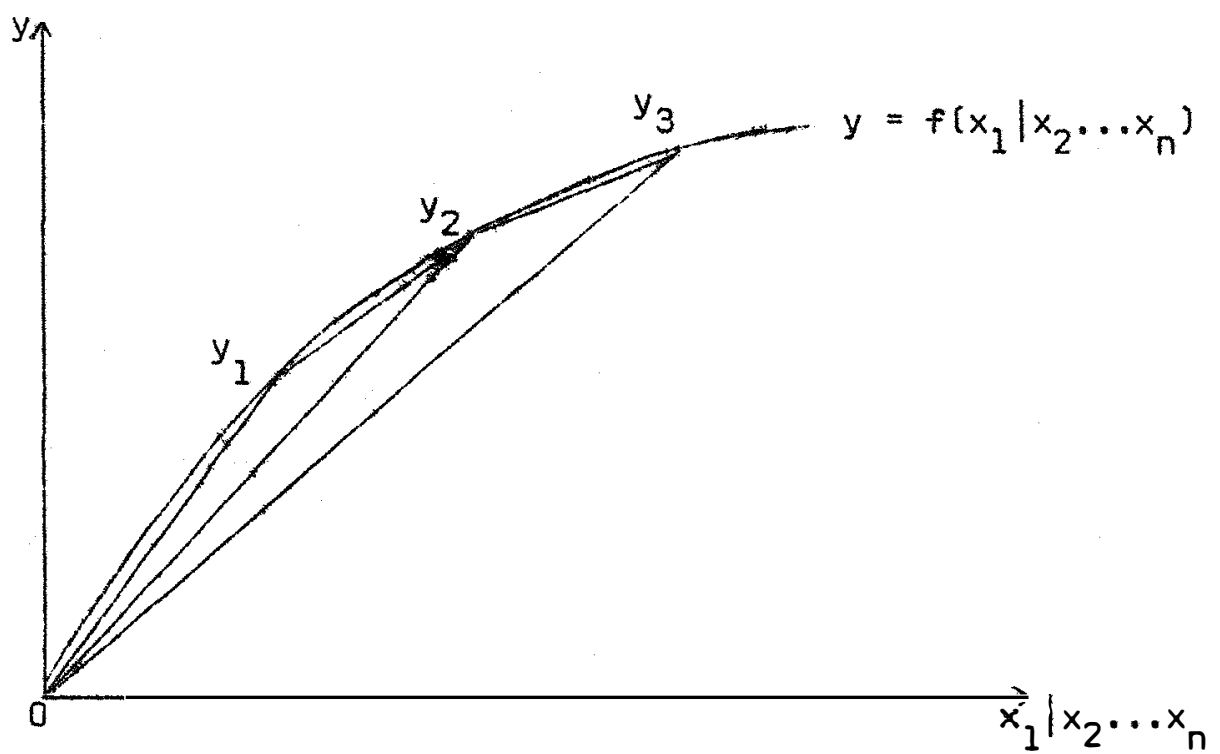

Figura 2 - A aproximação de uma função de produção usual através da P.L. 
Existem outros problemas relacionados ì maximização de receita líquida (margem bruta) esperada da unidade de produção agrícola: como exemplo pode-se mencionar a característica estática dos modelos de programação normalmente usados para este fim, e o fa to da respectiva função utilidade quase sempre depender de modo estrito do nível de renda. Por conseguinte, obtem-se com frequência al tos graus de especialização nas atividades, o que não encontra confirmação empírica porque eliminou-se riscos, incerteza, e ajustamen tos no tempo.

Ademais, tem-se imperfeições mais ou menos importantes que envolvem desde a abordagem necessariamente precária de investimentos e mudanças tecnológicas, até o tratamento simplificado ou ausente do impacto das polfticas voltadas para a agricultura. A aplicação desses modelos usuais de pD®gramação não se presta aos ca sos que exigem componentes dinámicos, a exemplo do que ocorre quando se estuda o crescimento da produção agrícola regional. Os proble mas identificados há pouco podem ser resolvidos por meio do M.P.R.

A diferença fundamental que distingue o M.P.R. daque le usual que se utiliza da P.L. estätica é a incorporação implícita da variável tempo através das equaçöes recursivas que conferem o com ponente dinàmico ao primeiro. Na verdade, trata-se de uma extensão da técnica de P.L., mas que abrange ou considera soluções de períodos anteriores no cumprimento de um objetivo, o qual pode também ser ampliado para uma função lexicográfica que não conte apenas com a maximização da receita líquida esperada. 
AHN (1972) estabelece em seu trabalho quatro objetivos principais, dispostos em termos de prioridade absoluta, que com põem um exemplo claro do que seja uma função lexicográfica:

(1) satisfação das necessidades de consumo de subsistência;

(2) possibilidade de escolha entre consumo e poupança;

(3) Inflexibilidade na opção quanto à composição das atividades; e, finalmente, sujeito às très anteriores;

(4) maximização da receita lfquida esperada.

Tem-se, desse modo, a superação de uma das limitações qữe sé apresentam quando se trabalha com a P.L. estática. No exemplo de função lexicográfica acima percebe-se também que, paralelamente ao deslocamento da regra exclusiva original (maximização da receita lí quida esperadal incorpora-se outro componente de importância, dado pelo terceiro objetivo daquela função. Este objetivo cuida de impedir a conhecida tendência à especialização que ocorre na P.L. Sua incorporação deriva-se diretamente do modelo de curto prazo de utilização da terra de Henderson. O modelo de Henderson dispõe que a alocação de terra se faz pela maximização da receita lfquida, mas com limites inferiores e superiores para as atividades produtivas.A seguir mostra-se o esquema deste tipo de modelo. 


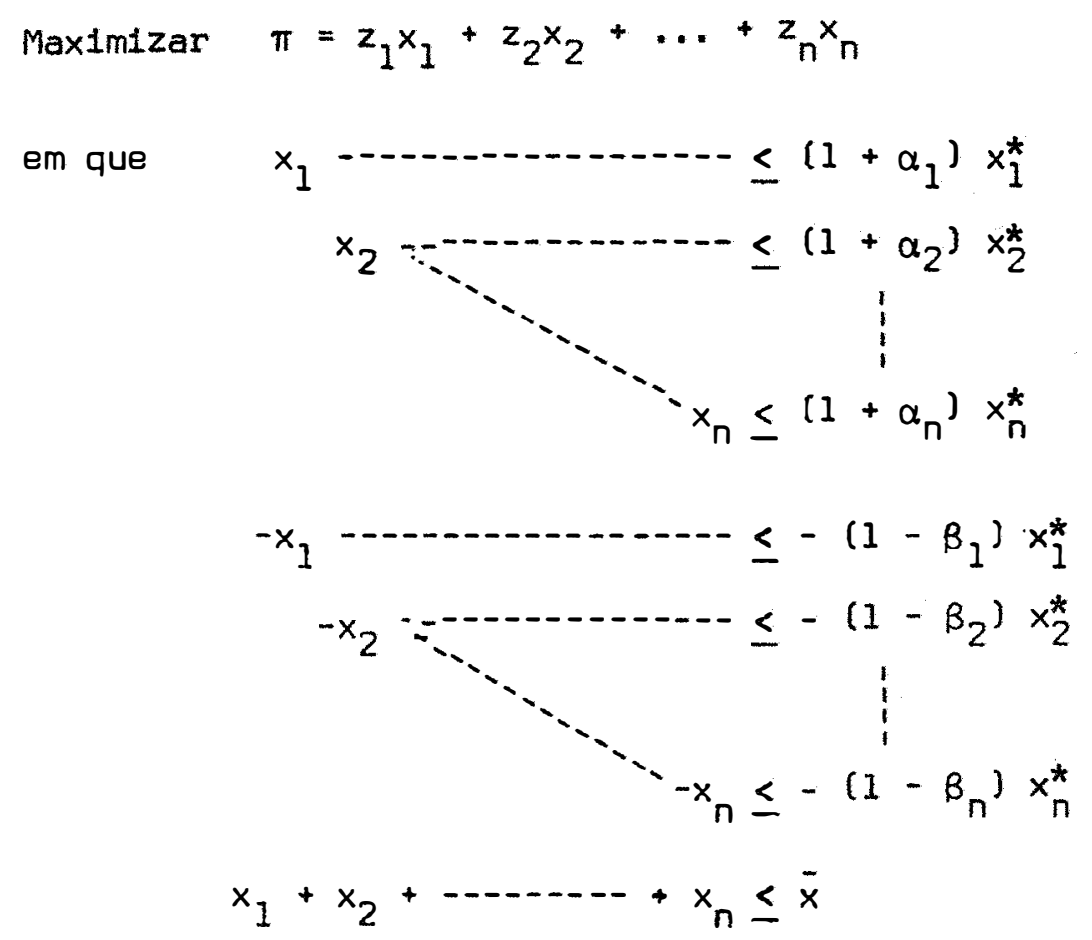

onde $x_{1}^{*}, x_{2}^{*}, \ldots, x_{n}^{*}$ são as áreas atualmente plantadas; $\alpha_{1}, \alpha_{2}, \ldots$ $\ldots, \alpha_{n}$ e $\beta_{1}, B_{2}, \ldots, B_{n}$ säo, respectivamente, a porcentagem má xima de aumento e diminuição da área plantada; $\bar{x}$ a disponibilidade total de terra; $e z_{n}$ as receitas 1 fquidas esperadas por unidade de ărea.

0 modelo, tal como se apresenta, projeta a solução em um perfodo para frente, sendo esta dada pelos $x_{1}$; dal sua característica de curto-prazo. A evolução do modelo para sua forma dinàmica è feita substituindo-se as inequações em (5) pela sua equivalente, por exemplo,

$$
x_{1}(t) \leq\left(1+\alpha_{i}\right) x_{i}^{*}(t-1)
$$

ao mesmo tempo em que se dinamiza, por seu lado, a função-objetivo. 
A versāo dinàmica do modelo de Henderson, com seus coeficientes de flexibilidade, aproxima-se bastante do modelo de de fasagem distribuída no tempo de Nerlove, no ponto em que ambos desenvolvem uma metodologia para a determinação da curva de oferta do produto no curto prazo. Com a diferença que o primeiro é mais abran gente e algo simplificado em relação ao segundo, porque este considera cada produto independentemente, mas com o suporte de hipóteses mais precisas.

Formalmente, o M.P.R. pode ser expresso por:

$$
\pi(t)=\sum_{j=1}^{n} z_{j}(t) x_{j}(t),
$$

sujeito à

$$
\sum_{j=1}^{n} a_{i j} x_{j}(t) \leq b_{1}(t)
$$

e

$$
x_{j}(t) \geq 0
$$

com

$$
b_{i}(t)=f_{1}\left[x_{j}^{*}(t-1), b_{1}(t-1), c_{i}(t)\right]
$$

onde $t=0, \ldots, \theta ; j=1, \ldots, n ; 1=1, \ldots, m$.

A equação (8) é uma medida da receita líquida (margem bruta) da agricultura regional a cada ano. 0 vetor $x(t)=\left[x_{j}(t)\right]$, de dimensão $n$, descreve as atividades que compreendem as de produção, consumo, compra, investimento e financeiras. Os coeficientes $z_{j}(t)$ formam um vetor de dimensão $n$ que, para as atividades de pro- 
dução, representam a diferença entre a receita e os custos variäveis, por unidade; ou os custos variáveis, no caso de atividades que por si não têm receita (pastagens, por exemplo): é evidente que o seu sinal será positivo e negativo, respectivamente. Do mesmo modo, quan do a $j$-ésima atividade for de compra de insumos, $z_{f}(t)$ será negativo; por exemplo: $z_{j}(t)$ é o valor negativo do salário, no caso da aquisição dos serviços de trabalho temporário não familiar, etc.

No caso das atividades de investimentos, o $z_{j}(t)$ cor respondente pode assumir o valor negativo da estimativa do custo anual das máquinas, representado por furos e depreciação linear. E finalmente para as atividades financeiras de empréstimo e poupança, $z_{j}(t)$ é o valor negativo da taxa de furos, e o valor do custo de oportunidade do dinheiro se depositado em agências financeiras, respectivamente.

As atividades de consumo familiar e outros encargos desse tipo, podem ser tratadas no mecanismo recursivo, onde uma par te da produção do perf́odo corrente é imobilizada para consumo no pe ríodo seguinte, segundo uma proporção a ser estabelecida para cada situação. As amortizações e débitos anteriores são incorporados como obrigações fixas, as quais são funções das soluções $x_{j}^{*}(t-k)$ dos periodos anteriores.

O sistema de inequações dado em ( 9 ) serve para restringir o nível das atividades por um confunto de limitações designadas pelo vetor $b(t)=\left[b_{i}(t)\right]$, de dimensão $m$, que estabelece $(a)$ a disponibilidade de recursos, tanto ao nível da empresa agrícola 
(terra, trabalho familiar, etc.), como a nfvel regional (limite de crédito, mão-de-obra assalariada, etc.); (b) as restrições financeị ras que "amarram" a disponibilidade de capital de giro às exigênclas das atividades produtivas; e (c) as restrições de comportamento, co mo os limites de flexibilidade da produção, e uma medida do processo de mudança tecnológica em termos de adoção e ajustamento.

A matriz dos coeficientes $a_{1 j}(t)$, de dimensão $m \times n$, representa a estrutura técnica e institucional da empresa. Conforme o tipo de restrição, esta pode ser fracionada compativelmente em sub-períodos para atender a épocas mais, ou menos exigentes. Isto ocor re, por exemplo, com os serviços de máquinas e de trabalho manual no preparo da terra ou na colheita, épocas de pico de utilização dos in sumos.

A desigualdade em (10) afirma claramente que as at1vidades não podem ser negativas e, no mäximo, não figuram na solução ótima (indicada pelos asterísticos), quando então $x_{j}^{*}(t)=0$.

A relação vista em (11) assevera que as restrições de pendem das soluções passadas $x_{j}^{*}(t-1)$, dos nfvels das disponibilidades prévias $b_{i}(t-1)$, e de um vetor $c(t)=\left[c_{1}(t)\right]$ que fornece infor mações exógenas ao modelo.

Esquematicamente: 
35.

\begin{tabular}{|c|c|c|c|c|c|c|}
\hline \multirow{2}{*}{$\begin{array}{l}\text { Tipos de } \\
\text { Restriçōes }\end{array}$} & \multicolumn{2}{|c|}{$\begin{array}{l}\text { Atividades de } \\
\text { Produção (l) }\end{array}$} & \multirow{2}{*}{$\begin{array}{l}\text { Ativida } \\
\text { des de } \\
\text { compra }\end{array}$} & \multirow{2}{*}{$\begin{array}{l}\text { Ativida } \\
\text { des de } \\
\text { investi } \\
\text { mento }\end{array}$} & \multirow{2}{*}{$\begin{array}{c}\text { Ativida } \\
\text { des fi- } \\
\text { nancei- } \\
\text { ras }\end{array}$} & \multirow{2}{*}{$\begin{array}{l}\text { Limites } \\
\text { (RHS) }\end{array}$} \\
\hline & $\begin{array}{l}\text { Tecnolo- } \\
\text { gia tra- } \\
\text { dicional }\end{array}$ & $\begin{array}{l}\text { Tecnolo- } \\
\text { gia mo- } \\
\text { derna }\end{array}$ & & & & \\
\hline Terra & $a_{i j}$ & $a_{i j}$ & $a_{i j}(2)$ & $0^{(4)}$ & 0 & $b_{1}$ \\
\hline Trabalho & $a_{i j}$ & $a_{11}$ & $a_{1 j}$ & $0^{(4)}$ & 0 & $b_{1}$ \\
\hline $\begin{array}{l}\text { Máquinas } 8 \\
\text { Equipamentos }\end{array}$ & $a_{i j}$ & $a_{i j}$ & $a_{1 j}{ }^{(3)}$ & $a_{1 j}$ & 0 & $b_{1}$ \\
\hline Liquide z & $a_{i j}$ & $a_{i j}$ & $a_{i j}$ & $a_{i j}$ & $a_{1 j}$ & $b_{1}$ \\
\hline $\begin{array}{l}\text { Comporta- } \\
\text { mento }\end{array}$ & $a_{i j}$ & $a_{i j}$ & 0 & $a_{i j}$ & 0 & $b_{i}$ \\
\hline $\begin{array}{l}\text { Recursos } \\
\text { Regionals }\end{array}$ & 0 & 0 & $a_{i j}$ & $a_{i j}$ & $a_{1 j}$ & $b_{1}$ \\
\hline
\end{tabular}

Flgura 3 - Esquema geral do modelo básico, mostrando as principais atividades e restrições em determinado perfodo. (5)

(1) Incorpora-se diferentes tecnologias pela alteração dos respectivos coeficlentes.

(2) Caso de aluguel e compra de terras.

(3) Caso de aluguel de máquinas.

(4) Nesse caso os investimentos são feitos apenas em má quinas; culturas perenes, por exemplo, não estão $a=$ qui consideradas.

(5) Figura adaptada de AHN (1972). 


\section{2 - 0 Modelo Empírico}

\section{2 .1 - As at ividades}

As atividades que constam do modelo são:

(a) atividades produtivas agrícolas anuais, por tecnologia;

(b) atividades produtivas agrícolas perenes;

(c) atividades produtivas de pecuária;

(d) atividades de consumo (animal e humano);

(e) atividades financeiras (de empréstimo e poupança);

(f) atividades de investimento (em maquinaria e implementos e culturas perenes);

(g) atividades de pastagem;

(h) atividades de compra;

(i) atividades de venda;

(j) atividades de transferēncia;

(k) atividades intermediárias.

- O primeiro grupo das atividades produtivas agrícolas anuais inclui batata das águas e da seca, algodão, cana, mandioca, tomate envarado e soja. Esta última não figura para o estrato peque no, aparece no estrato médio a partir do ano agrícola de 1973/74, e no estrato grande durante todo o perf́odo. No caso do tomate, este igualmente não aparece como atividade para o estrato pequeno porque, apesar de seu plantio exigir áreas não muito grandes, ele é explora do na base de arrendamento apenas nos estratos superiores. 
A cana foi transformada em atividade anual porque é comum o produtor dividir a área em talhões que se alternam em plantio (de ano e melo), soca e ressoca (2 ou 3 vezes); assim, para cada hectare de cultura com cana-de-açúcar pressupôs-se um rodfzlo per feito através da média dos custos e receitas como se procedesse sem pre de modo a se ter as várias fases da cultura simultaneamente.

Deste primeiro grupo, apenas batata das águas e algodão possuem duas tecnologias distintas, que se distinguem principalmente pelo tipo de energia de tração utilizada nas operações de preparo do solo, plantio, tratos culturais e colheita, caso usem in tensivamente maquinaria, ou usem intensivamente trabalho animal e/ ou humano. Neste estudo, a diferença marcante é em termos de tecnologia mecânica, enquanto que a tecnologia bioquímica é considerada de modo secundário e com diferenças bem menos acentuadas (em adubação, por exemplo). Este fato é uma limitação do modelo que, contando com mais alternativas de tecnologia, teria melhores condiçöes de descrever as mudanças tecnológicas efetuadas na região durante o perído analisado. A falta de maiores informações sobre o rendimento das culturas frente a novas tecnologias (novas variedades, por exem plo) empobrecem o modelo.

Uma diferença fundamental do modelo exposto em confronto com os demais revisados na bibliografia é a sua multiplicida de de atividades as mais variadas numa região ampla e complexa como a DIRA de Campinas. Embora o esforço de síntese nesse caso tenha si do bem maior, por outro lado não se escapou de simplificações que 
podem comprometer o desempenho do modelo.

0 segundo grupo das demais atividades agrícolas anuais, inclui milho, arroz de sequeiro, feijão das águas e da seca. Com exceção do arroz, as demais possuem duas tecnologias distintas, nos moldes fá descritos anteriormente. Alguma coisa pode ser dita com relação à existência destas culturas como intercalares, e sua importância como subsistência para a população dos trabalhadores fä miliares. Usou-se um critério bastante simplificado no caso de consumo dos produtos retidos na propriedade. Quanto ao cultivo interca lar, este não foi considerado; as culturas de subsistência são tratadas separadamente no custo de produção do IEA, não havendo custos alternativos que considerassem cultura intercalar.

0 fato de feijão e batata das águas e da seca usarem a terra simultaneamente não é correto, mas em vista das modificações que teriam que ser feitas apenas para atendê-1o, isto foi desprezado. O mesmo aconteceu com a técnica de rotação de culturas, eventualmente um expediente muito usado. A separação das culturas anuais em dois grupos, por sua vez, explica-se porque o tratamento dispensado ao segundo grupo difere do primeiro pelas necessidades de liga ções com as atividades de consumo, compra e venda; o segundo grupo, juntamente com o leite, formam os ftens de consumo humano e animal. - As atividades produtivas agrícolas perenes incluem o café e citrus de modo geral. Na categoria de citrus incluem-se as laranjas, limães, pomelos e outras frutas citricas. Neste caso usou-se os dados e coeficientes do ftem "Laranja" do custo de produção 
do IEA como uma variável representativa de toda a categoria.

Há argumentos que validam tal procedimento: a laranJa é a atividade preponderante; seus custos de produção e operacionais se comparam, de modo muito aproximado, aos das restantes frutas cítricas, segundo opiniōes de técnicos; tinha-se, como se verá, a divisão dos tipos de terras com culturas perenes, a esse dadoldos melhores disponíveis) sería desperdiçado caso não se incluísse outras frutas cítricas; além do mais, mesmo considerando apenas laran Jas, a rigor dever-se-ia então dar espaço às diversas variedades que também diferem entre si, o que não era possível. A questão de preços e épocas de colheita era a mais crítica porque sujeita a variações, e daí o argumento final para a padronização de acordo com a disponibilidade das informações do IEA.

Quanto ao café, cabe dizer que algumas modificações foram introduzidas nos custos de produção originais, de acordo com consultas a outras fontes. Ainda que a tecnologia considerada tenha sido única, é provável a existência na prática de muitas outras.

Não foi admitida a possibilidade de erradicação das culturas perenes. Apenas considerou-se uma depreciação física linear da cultura em termos da sua vida ütil, traduzidas pela subtração de 1/26 e 1/20, respectivamente do café e citrus em produção, a cada ano. No caso das geadas que atingiram os cafezais em 1972 e 1975, ha via a alternativa de considerá-las exogenamente através do vetor $c(t)=\left[c_{1}(t)\right]$ para os anos em questão; o mesmo poderia ocorrer com relação à crise da laranja por volta de 1974 e 1975. 
Dutro detalhe que deve ser lembrado é que nem todas as atividades agrícolas da região foram incluídas. As exceções mais flagrantes são as várias atividades hortıgranjeiras, reflorestamento e culturas como cebola, amendoim, etc. As justificativas para a exclusão destas atividades prendem-se a que, ou ficam confinadas a áreas restritas, em sub-regiões especializadas (caso da fruticultura temperada na sub-região de Campinas], ou são inexpressivas para a região como um todo (caso do amendoim e outras). Fez-se uma tentati va, ademais, no sentido de descontar as exigências mais importantes tomadas por aquelas atividades, como mão-de-obra residente disponfvel, disponibilidade de crédito, etc. O rigor de tais descontos é, no entanto, duvidoso.

- As atividades de pastagens incluem pasto natural e pasto artificial. Normalmente estas atividades requerem investimento como destoca ou reforma, mas neste trabalho decidiu-se transformá-las em atividades anuais.

No caso das pastagens naturais foram levados em conta os custos das sementes por hectare para plantio à lanço de capim gordura e o trabalho humano para executá-la; como previu-se a reforma a cada 8 anos e mais o trabalho anual de roçada,o custo da re forma foi dividido por 8 , e somado ao da roçada, para obter-se o cus to anual. No caso das pastagens artificiais, tratou-se de verificar qual o tipo de pasto mais utilizado para este fim, e o seu custo de produção é que foi levado em conta, do mesmo modo que para a pastagem natural. Completando, resta afirmar que ao pasto natural confe- 
riu-se o preço pago pelas sementes no comércio local, e os coefic1entes técnicos foram retirados do trabalho de PERROCO (1973), enquan to que para pasto artificlal optou-se pelo custo do colonião planta do por mudas dado pelo IEA.

- As atividades pecuärias Incluem gado de corte, produ ção de leite $B$ e $C$, e suinocultura tipo banha e tipo carne.

Esta ültima figura apenas nas propriedades correspon dentes ao estrato médio, constituindo cerca de 20 a $30 \%$ do total de suínos deste estrato. Suinocultura parece ser uma atividade que se encontra em transição na região, embora de modo lento, e como suíno tipo carne é de produção especializada, com raças apuradas e alta tecnologia, decidiu-se inclui-la somente no grupo de propriedades que era, provavelmente, o mals tecnificado.

No caso de pecuáría bovina de corte, consultou-se es peclalistas que forneceram a composição média do rebanho para esta atividade, e com base nessa composição usou-se os requerimentos estabelecidos por Perroco, adaptados para a composição observada na região. A composição fol mantida constante durante todo o período, seguindo ainda parecer dos especialistas, e atendendo às atividades de cría, recrla e engorda, que são normalmente realizadas.

Na produção de leite $C$, os coeficientes foram retira dos da publicação "Agricultura em São Paulo" e adaptados de acordo com a composição do rebanho, específica, obtida da mesma fonte a que se recorreu no caso da pecuária bovina de corte. Os dados referem-se diretamente à bacla leiteira de Campinas, referidos sempre ao 
produtor médio.

Na produção de leite $B$, utilizou-se de dados internos do IEA, maciçamente influenciados pela técnica usada na bacia leiteira do Vale do Paraíba, a malor do Estado e que fornece as informações básicas para o Instituto. Mas a composição do rebanho e exigências não devem diferir muito entre as duas bacias leiteiras, visto ser atividade que requer padrões bastante rígidos de manejo, além dos próprios rigores da legislação.

Devido ao consumo na propriedade de leite $C$, e pelas ligações entre si, ambas as produções de lelte possuem atividades intermediárias.

Para sufnos tipo banha os dados basearam-se numa publicação da CATI e nos tomados de PERES (1974), dos quais resultou uma composição de rebanho submetida ainda a técnicos do Departamento de Zootecnia dos Não-Ruminantes da ESALQ. Para suíno tipo carne, o mencionado Departamento da ESALQ forneceu os custos de produção e os coeficientes técnicos, assim como a composição do rebanho.

- Atividades de consumo dizem respeito ao consumo alimentar humano e animal: de arroz, feijão e leite $C$, para aquele, e de milho, para este. As exigências foram tomadas em termos de uma relação fixa a cada ano, conforme o número de trabalhadores familia res ou número de unidades animal, e o número de animais de trabalho, respectivamente. Nem todas as atividades pecuárias recebem milho, apenas suíno tipo carne e pecuária de leite $B$, como parte da ração dispensada a estas criações, e animais de trabalho. 
- Atividades financeiras incluem as de empréstimo e pou pança. As atividades de empréstimo esgotam-se ao nivel de crédito rü ral disponível para o setor na regiäo; durante o período, houve oscilações nas taxas de juros que além disso, previlegiaram alguns Itens, razão pela qual divide-se em dols grandes grupos: crédito para investimento e crédito para custeio. Este último ainda subdivide-se em crédito para compra de fertilizantes, insumos modernos (ta xas diferenciais durante o perfodol, e outro ftem geral para as demais operações. 0 volume de crédito para investimento abrange todo - elenco constante deste ftem, embora o trabalho restrinja seu uso à aquisição de máquinas e implementos. Outros tipos de investimentos como barragens, benfeitorias, currais, etc., não figuram no modelo, nem Investimento para controle da erosão, formação de pastagens e destoca, e mesmo os investimentos em culturas perenes não tomam recursos dessa fonte. A atividade de poupança, por seu turno, aparece como um custo de oportunidade dado ao capital monetário frente às atividades produtivas; para tanto, tomou-se como complemento o conhecimento dos agricultores das taxas de remuneração das cadernetas $Y$ de poupança. As fontes de crédito que não as oficlais foram desprezadas, bem como as operações financelras que cobrem a comercialização dos produtos.

- As atividades de investimento incluem investimentos no complexo trator-implemento, em colhedeiras de soja e investimentos em culturas perenes. De todos os implementos usados no trabaIho agrícola, fez-se uma seleção dos mais importantes e que constam 
do custo de produção do IEA. Com base na série de dados disponíveis estimou-se a relação média trator/implemento durante o perfodo para cada grupo de propriedades (estrato). As outras máquinas e implemen tos que não fazem parte da relação participam dos custos apenas em termos de seus respectivos custos diários operacionais sem levar-se em conta sua aquisição e depreciação. Os investimentos em animais de serviço foram desprezados porque em todos os estratos constatou-se queda de sua participação nas tarefas agrícolas, ou senão permanece ram em número relativamente constante; a essa constatação serviu de apoio o levantamento do número de muares presentes nas propriedades. Os financiamentos para máquinas sofrem um período de carência de 2 anos, após os quais as obrigaçōes em termos de juros simples e pagamento do principal em 7 anos são descontados do retor no líquido anual. Para o complexo trator-implemento imputou-se uma vida útil de 10 anos com depreciação linear, restando um valor de sucata de 10\% do preço de aquisição; no caso das colhedeiras, a diferença está apenas no tempo de vida útil, que é de 14 anos. Os tra tores de várias potências foram por sua vez transformados num equivalente-padrão de 61 HP através da ponderação de seus respectivos preços, que se julga acompanhar de perto, ou pelo menos manter uma determinada proporção estável, com o rendimento nas operações.o trạ tor de 61 HP justifica-se por ser uma máquina de porte médio a gran de, no que acompanha as tendências mostradas pela agricultura da re gião, e por ajustar-se perfeitamente aos dados mais recentes do IEA que já no seu custo de produção para $1977 / 78$ utiliza-o como média. 
0 fato de o modelo näo incluir todos os tipos de investimento não o compromete, e conforme a colocação de DAY (1963), um plano detalhado de investimento não se torna absolutamente neces sário porque sua auséncia é justificada considerando-se que na medi da em que se estabelece o nivel ótimo das atividades, isto faz com que os fatores que são fixos no curto-prazo, como benfeitorias, ins talaçöes värias, etc., fiquem também determinados.

- Atividades de compra incluem aquisições de insumos va riáveis mais os Itens de consumo (exceto leite C) para suprir eventuais faltas caso a produção própria não seja suficiente.Porém,mais significativas são as compras de insumos variáveis a exemplo dos ser viços de trabalho, fertilizantes $(N, P$ e $K)$, corretivo e insumos mo dernos (sementes e defensivos). Destes, com exceção dos serviços de trabalino e do insumo corretivo dos solos, lembra-se que há a possibilidade de serem adquiridos através do uso direto do crédito ou,al ternativamente, por meio do uso de recursos próprios. Isto torna os mecanismos financeiros-monetário mais flexíveis e reais devido às possibilidades que se apresentam. Outros custos variáveis (principalmente custos diários de operações com máquinas e animaislsão des contados diretamente da receita bruta.

- As atividades de venda complementam as atividades pro dutivas que se prestam ao consumo humano e animal, sendo simplesmen te uma forma apropriada de incorporar as ligações e balanços que se fazem necessários para a coerēncia do sistema. Esta mesma forma foi utilizada também para o caso das culturas perenes que, embora não es 
tejam ligadas a consumo na propriedade, recebem igual tratamento de vido às diferentes produtividades no período de maturação.

Há também a questão da venda da mão-de-obra familiar que foi uma maneira de fornecer um custo de oportunidade aos serviços do trabalho familiar, fenōmeno que parece ocorrer com alguma fre quência na região, em razão da sazonalidade das tarefas agropecuárias.

- Atividades de transferência dizem respeito, em primeiro lugar, às possibilidades do uso da terra; esta fol dividida em três categorias: terra para culturas anuais, terra para culturas perenes e terra para pastagens. A transferência permite que se proceda ao seu uso com alternativas, desde que se obedeça a uma direçäo: terras de melhor qualidade podem ser tomadas por atividades (culturas) menos exigentes em solo.

Em segundo lugar, as transferênclas referem-se também à simples acomodação como, por exemplo, facilitar os requerimen tos de consumo de milho dos animals de tração.

- Atividades intermediärias são apenas um desdobramento das atividades de culturas perenes, que cobrem os anos de plantio até a maturação completa da cultura. Em cada uma dessas fases, tanto os custos como as receitas diferem entre si como referido no caso da cana, mas neste caso a transformação em atividade anual não era desejável. Optou-se então pelo desdobramento do seguinte modo:a decisão de investir (plantio) projeta a média da receita líquida ob tida pela divisão entre a diferença da receita total e custo total 
e o perfodo de vida útil da cultura, a cada ano lobedecendo aos diferentes níveis de rendimento de cada fase), com a exclusão dos cus tos no perfodo corrente. Uma vez realizado o plantio, a área planta da passa à fase seguinte no próximo perfodo, obrigatoriamente.

Um exemplo: o café possui cinco vetores (atividades) para representá-lo: (1) plantio, (2) café no $1^{8}$ ano, (3) café no $2^{8}$ ano, (4) café no $3^{8}$ ano, e (5) café em produção. As atividades intermediárias cobrem as fases de plantio até o cafezal entrar em pro dução quando então chamou-se-lhe, junto com citrus em produção, de "atividades produtivas agrícolas perenes".

\section{2 .2 - o critério de otimização}

o critério de otimização estabelece a função objetivo explfcita a cada perfodo, sujeita a um conjunto de restriçōes que serão expostas adiante. 0 critério de otimização para um dos grupos de propriedades (estrato) num determinado ano $t$ é dado por:

$$
\begin{aligned}
\pi(t)= & \sum_{j=1}^{g}\left[z_{j}(t) x_{j}(t)-c_{j}(t) x_{j}(t)\right]-\sum_{j=10}^{16} c_{j}(t) x_{j}(t)+ \\
& +\sum_{j=17}^{18} z_{j}(t) x_{j}(t)-\sum_{j=19}^{26} c_{j}(t) x_{j}(t)+ \\
& +\sum_{j=27}^{29}\left[z_{j}(t) x_{j}(t)-c_{j}(t) x_{j}(t)\right]-\sum_{j=30}^{31} c_{j}(t) x_{j}(t)- \\
& -\sum_{j=32}^{33} c_{j}(t) x_{j}(t)-\sum_{j=42} c_{j}(t) x_{j}(t)-\sum_{j=44} c_{j}(t) x_{j}(t)-
\end{aligned}
$$




$$
-\sum_{j=46}^{61} c_{j}(t) x_{j}(t)+\sum_{j=62}^{71} z_{j}(t) x_{j}(t)+\sum_{j=72}^{72} z_{j}(t) x_{j}(t),
$$

onde: $z_{j}(t), j=1, \ldots, 9$, é o retorno bruto da $j$-ésima atividade com uma ou mais tecnologias (em Cr\$ por ha);

$c_{j}(t), j=1, \ldots, 9$, são os custos variáveis que incidem na $j-\dot{e}-$ sima atividade ${ }_{\text {s }}$ ano $t$ (em CI\$ por ha). Representam apenas aqueles que não figuram explicitamente como atividades de coluna, tratando-se principalmente de custos operacionais de máquinas, implementos e animais de trabalho, mais o diferencial entre o salário do tra torista e o trabalhador residente;

$c_{j}(t), j=10, \ldots, 16$ são os custos variáveis semelhantes aos de $j=1, \ldots, 9$, mas que incidem sobre a $j$-ésima atividade no ano $t$ (em Gr\$ por ha);

$z_{j}(t), j=17,18$, é a expectativa de retornos líquidos "atuais" da j-ésima atividade no ano $t$ (em Cr\$por ha).Não deve ser computado na receita líquida "efetivamente rea lizada", pois que é apenas uma medida da vantagem rela tiva de se investir em culturas perenes;

$c_{j}(t), j=19, \ldots, 26$, são custos que se identificam com os $j=1$, ...,9, mas neste caso referem-se ao estágio da vida útil da j-ésima atividade, desde o plantio até sua franca produção, no ano $t$ (em $\operatorname{Cr} \$$ por ha);

$z_{j}(t), j=27, \ldots, 29$, é o retorno bruto da $j$-ésima atividade no ano $t$ (em $\operatorname{Cr} \$$ por unidade-matriz); 
$c_{j}(t), j=27, \ldots, 29$, são os custos variáveis da $j$-ésima atividade no ano $t$ (em $\operatorname{Cr} \$$ por unidade-matriz);

$z_{j}(t), j=30,31$, são os custos variáveis da $j$-ésima atividade no ano $t$ (em Cr\$ por unidade-matriz). Diferem de $j=27$, ... 29 porque leite desdobra-se também em atividade de consumo:

$c_{j}(t), j=32,33$, são os custos variáveis da $j$-ésima atividade no ano $t$ (em Cr\$ por ha);

$c_{j}(t), j=42,43$, é uma medida que acompantha a decisão de acio nar a j-ésima atividade no ano $t$ lem Cr\$ por unidade-máquina). Usa-se o critério de depreciação linear aplicado à diferença entre o preço de aquisição da unidade e 10\% do seu valor original ao cabo da vida útil: $c_{j}(t), j=44,45, \bar{e}$ a taxa de juros da $j$-ésima atividade no ano $t$;

$c_{j}(t), j=46, \ldots, 61, e ́$ o coeficiente da $j$-ésima atividade no ano $t$. Este confunto de coeficientes é bastante diversificado porque acompanha variáveis muito diferentes en tre si englobadas nas atividades de compra. Assim, $c_{j}(t)$ com $\mathrm{j}=47,48$ é um número unitário puro que contabiliza para a função-objetivo os gastos com insumos modernos, que podem ser adquiridos diretamente ou através do cré dito: $c_{j}(t)$ com $j=49, \ldots, 54$ tem o mesmo sentido anterior, mas agora relacionado à compra de fertilizantes lem Cr\$ por tonelada, acrescido ou não da taxa de ju- 
50.

ros $\} ; c_{j}(t) \operatorname{com} j=55, \ldots, 58$ refere-se ao salário pago à mão-de-obra residente e à mão-de-obra contratada,nos três sub-períodos em que esta última se divide lem Cr\$ por homens-dias); $c_{j}(t)$ com $j=59$ refere-se à compra de corretivo (em $\operatorname{Cr} \$$ por tonelada); e finalmente, $c_{j}(t)$, com $j=60, \ldots, 62$, diz respeito à compra de arroz, milho e feljão (em Cr\$ por saca);

$z_{j}(t), j=62, \ldots, 68$, é a receita bruta da $j$-ésima atividadelem Cr\$ por saca ou litro ou caixa), e $z_{j}(t), j=69, \ldots, 71$ é o salário da mão-de-obra familiar dividida em três sub-perfodos no ano $t$ (em Cr\$ homens-dias). As atividades correspondentes a $j=62, \ldots, 71$ são atividades de venda;

$z_{j}(t), j=72$, é a taxa de remuneração para o capital monetário aplicado em caderneta de poupança;

$x_{j}(t), j=1, \ldots, 72$, são as atividades colunas.

As atividades estäo descritas no Apêndice 1 .

\subsection{3 - Modelo de expectativa de preços}

Todos os coeficientes da função objetivo são exógenos e, em sua maioria, representam os preços de produtos e insumos, além das taxas de juros de empréstimo e poupança, similares de expectativa de renda "atualizada" como no caso das atividades de investimento em culturas perenes, etc. Com o intuito de se aproximar 
mais do processo real de decisão dos produtores concebeu-se um modelo simples de expectativa de preços dos produtos agrícolas ao pas so que para os preços de insumos adotou-se a pressuposição de conhecimento perfeito por parte dos agricultores. E fácil imaginar a utilidade deste procedimento se se recordar que as decisões sobre o plantio faz-se "ex-ante", 1sto é, antes do conhecimento do preço fí nal; este, como se sabe, varia bastante de um ano a outro para os produtos do setor agrícola. Via de regra sua expectativa não coinci de exatamente com a realidade, dar as decisões um tanto distintas ca so o agricultor soubesse por antecipação o preço final dos seus pro dutos.

Optou-se por um modelo simplificado de formação de ex pectativa de preços dos produtos. Numa economia não fortemente inflacionária, a simples defasagem de um período nos preços dos produtos talvez fosse suficiente para cobrir os principais efeitos pro curados por um modelo de expectativa, em vista do peso preponderante que reconhecidamente se confere às experiências passadas recentes. Neste estudo tenta-se explicar a formação de expectativa de prê ços em termos inflacionários para as condições do Brasil. Para tanto tentou-se o modelo geral sumarizado adiante.

Dados $\underline{P}$ como sendo fndice dos preços recebidos pelos agricultores do Estado de São Paulo (Instituto de Economia Agrícola - média ponderada dos Indices dos preços recebidos pelos 21 principais produtos agrícolas) e I como sendo o indice geral de preços(ín dice 2 da Fundação Getülio Vargas\}, tem-se: 


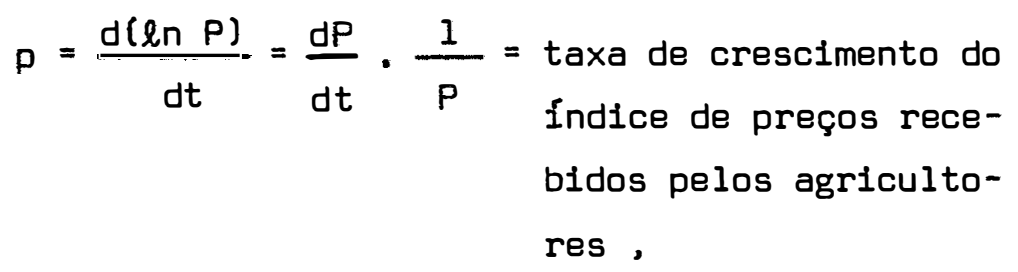

e

$$
i=\frac{d(\ell n I)}{d t}=\text { taxa de crescimento da inflação. }
$$

Com estes elementos, estimou-se originalmente a regressão linear com as séries temporais de crescimento dos índices disponíveis deste 1948, tomando-se o ano de $1966=100$, que assume a forma:

$$
p_{t}=\alpha_{1}+\beta_{1} i_{t-1}+\gamma_{1} i_{t-2}+\delta \alpha_{2}+\delta \beta_{2} i_{t-1}+\delta \gamma_{2} i_{t-2}+\varepsilon_{t}
$$

onde $\alpha_{1}$ e $\alpha_{2}=$ interceptos;

$$
\begin{aligned}
& B_{1}, B_{2} \text { e } \gamma_{1}, \gamma_{2}=\text { coeficientes da regressäo; } \\
& \delta=\text { variável binária; } \delta=0 \text { se } \delta E t=1948, \ldots, 1963 ; \text { e } \\
& \qquad \delta=1 \text { se } \delta \varepsilon t=1964, \ldots \\
& \varepsilon_{t}=\text { termo de erro. }
\end{aligned}
$$

A variável binária é inserida para tentar capturar a mudança na tendência inflacionária a partir de 1964. Devido ao pequeno número de observações não fol possível capturar de maneira sí milar o recrudescimento inflacionärio desde 1973.

O ajustamento da regressão original (13) fez-se "pas so a passo". o que consiste em incluir a cada vez uma nova variável independente das relacionadas inicialmente a partir do confunto mais 
simples para decidir quajs teriam maior poder de explicação. Revelou-se assim a seguinte modelo como o que melhor se ajustou aos dados:

$$
p_{t}=\alpha_{1}+\beta_{1} 1_{t-1}+\delta B_{2} i_{t-1}+\varepsilon_{t}
$$

Tendo-se (14) foram estimados os respectivos coeficientes para um determinado ano, obtendo-se então $\rho_{t}$ que, por sua vez, serviu de base para inflacionar igualmente os preços dos produ tos agrícolas do ano anterior, usados por fim na funçäo-objetivo. A cada ano, a partir do inicial, era acrescentada uma nova observação, de maneira que se teve sete regressões.

\section{2 .4 - 0 conjunto das equações restritivas}

\subsubsection{1 - Restrições de terra}

$$
\begin{aligned}
& \sum_{j=1}^{16} a_{i j} x_{j}(t)+\sum_{j=37}^{37} a_{i j} x_{j}(t) \leq b_{i}(t) ; i=1 \\
& \sum_{j=17}^{26} a_{i j} x_{j}(t)-\sum_{j=37}^{37} a_{i j} x_{j}(t)+\sum_{j=38}^{38} a_{i j} x_{j}(t) \leq b_{i}(t),
\end{aligned}
$$

$\operatorname{com} i=2$,

$$
\sum_{j=32}^{33} a_{i j} x_{j}(t)-\sum_{j=38}^{38} a_{i j} x_{j}(t) \leq b_{i}(t) ; \quad i=3
$$

A inequação (15) assegura que a exigência de terrapelas culturas anuais mais a quantidade tomada eventualmente pelas cul turas perenes não pode ultrapassar o limite disponf́vel de terra de 
qualidade I (para culturas anuais).

A inequação (16) garante que as requisições de terras para culturas perenes (primeiro termo), subtraldas da parcela eventualmente transferida para terra I (segundo termo), mais a parcela tomada por pastagens (terceiro termo), seja inferior ao limite fixado de terra de qualidade II (terras para culturas perenes).

A inequação (17) diz que os coeficientes de terra pa. ra pastagens menos a porção que se transfere para terra II não são maiores que o limite de terra de qualidade III (terras para pastagens ).

\subsubsection{2 - Restrições de mão-de-obra}

$$
\sum_{j=1}^{33} a_{i j} x_{j}(t)-\sum_{j=54}^{57} a_{i j} x_{j}(t)+\sum_{j=69}^{71} a_{i j} x_{j}(t) \leq b_{i}(t),
$$

$\operatorname{com} i=4,5,6$,

$$
\begin{aligned}
& \sum_{j=54}^{54} a_{i j} x_{j}(t) \leq b_{i}(t) \quad ; \quad i=7 \\
& \sum_{j=55}^{57} a_{i j} x_{j}(t) \leq b_{1}(t) \quad ; \quad i=8,9,10
\end{aligned}
$$

A inequação (18) assevera que o somatório dos coeficientes técnicos de mão-de-obra para as atividades produtivas (primeiro termol somados aos dias-homens vendidos com base no custo de oportunidade da mão-de-obra familiar (terceiro termo) tem que respeitar a disponibilidade de mão-de-obra familiar na i-ésima restrição, acrescida da possibilidade de compra de dias-homens correspon- 
55.

dentes de mäo-de-obra residente e contratada (segundo termo).

A inequação (19) limita a compra de dias-homens em termos de trabalhadores residentes, e a inequação (20) o faz igual mente para unidades de trabalho contratados em três diferentes sub-períodos durante o ano agrícola.

\subsubsection{3 - Restrições financeiras}

$\sum_{j=10}^{16} a_{i j} x_{j}(t)+\sum_{j=17}^{26} a_{i j} x_{j}(t)+\sum_{j=30}^{31} a_{i j} x_{j}(t)-\sum_{j=45}^{45} a_{i j} x_{j}(t)+$

$$
\begin{aligned}
& \sum_{j=50}^{58} a_{i j} x_{j}(t)+\sum_{j=59}^{61} a_{i j} x_{j}(t)-\sum_{j=62}^{63} a_{i j} x_{j}(t)- \\
& -\sum_{j=69}^{71} a_{i j} x_{j}(t)+\sum_{j=72}^{72} a_{i j} x_{j}(t) \leq b_{i}(t) ; \quad i=11 \\
& \sum_{j=45}^{45} a_{i j} x_{j}(t)+\sum_{j=50}^{53} a_{i j} x_{j}(t) \leq b_{i}(t) ; \quad i=12
\end{aligned}
$$

Em (21) tem-se o mais importante fluxo monetärio-financeiro uma vez que todos os desembolsos (ou quase todos) nele figura, e também algumas atividades que contribuem para a liquidez do sistema. Generalizando, a inequação (21) diz que a disponibilidade de caixa (capital de giro) no ano $t$, acrescida do montante de crédito de custeio mais a metade do valor das vendas de leite e mão-de-obra familiar (para impedir uma liquidez que não seria real) são obriga- 
toriamente superiores, ou pelo menos iguais ao capital financeirousado na poupança mais o dispèndio com custos operacionais e insumos variāveis.

A inequação (22) estabelece o nível máximo de crédito de custeio disponível no ano $t$.

$$
\sum_{j=42}^{43} a_{i j} x_{j}(t) \leq b_{i} \quad ; \quad i=13
$$

$$
\sum_{j=42}^{43} a_{i j} x_{j}(t) \leq \sum_{j=44}^{44} a_{i j} x_{j}(t) ; \quad i=14
$$

Em (23) limita-se os investimentos pelo montante total de crédito disponível para este fim no ano $\underline{t}$. Na verdade, esta restrição dificilmente seria limitante visto que o limite oferecido suplanta em muito a exigência, por incluir todos os tipos de in vestimentos, a marioria dos quais não foi considerado neste trabalho.

Em (24) garante-se que todo o desembolso para as ati vidades de investimento em maquinaria provém do crédito para essa fí nalidade.

$$
\sum_{j=72}^{72} a_{i j} x_{j}(t) \leq b_{i}(t) \quad ; \quad i=15
$$

A inequação (25) impõe que a poupança no ano $\underline{t}$ não pode exceder a um limite dado pela disponibilidade de recursos prö- 
prios no mesmo ano.

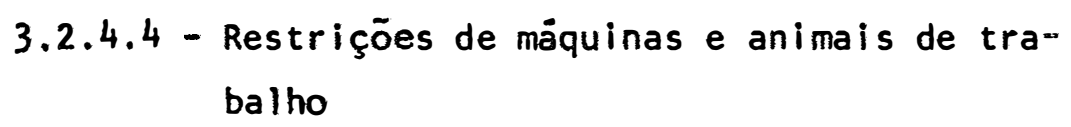

$$
\sum_{j=1}^{26} a_{i j} x_{j}(t)+\sum_{j=32}^{33} a_{1 j} x_{j}(t)-\sum_{j=42}^{42} a_{i j} x_{j}(t) \leq b_{i}(t) ;
$$

$\operatorname{com} i=16,17,18$,

$\sum_{j=42}^{42} a_{1 j} x_{j}(t) \leq b_{i} ; \quad i=19$

Em (26) assegura-se que a exigência em dias-máquina do conjunto trator-implemento para culturas anuais e perenes $\left(1^{8}\right.$ termo) somado aos mesmos tipos de necessidades para pastagens $\left(2^{\circ}\right.$ termol são condicionados à disponibilidade prévia do estoque de maquinaria (transformadas em dias-máquina) mais a liberação de novas unidades permitida pelo investimento (o $3^{\circ}$ termo). Este último, por sua vez, tem um limite imposto por (27). A disponibilidade de máqui nas subdivide-se no ano em três sub-períodos assinalados por $i=16$, 17,18 .

$$
\begin{aligned}
& \sum_{j=1}^{26} a_{i j} x_{j}(t)-\sum_{j=34}^{36} a_{i j} x_{j}(t) \leq 0 ; \quad i=20,21,22 \\
& \sum_{j=34}^{36} a_{i j} x_{j}(t) \leq b_{i}(t) \quad ; \quad i=23,24,25
\end{aligned}
$$


58.

A inequação (28) é tão somente um arranjo especial na matriz para facilitar a atividade de consumo de milho dos animais de serviço. Conjugada com (29) estabelece que o total de dias-animal exigido pelas atividades produtivas que os utilizam não deve exceder sua restrição prévia a cada sub-período no ano $t$.

$$
\sum_{j=t_{i}}^{g} a_{i j} x_{j}(t)-\sum_{j=43}^{43} a_{i j} x_{j}(t) \leq b_{i}(t) ; \quad i=26
$$

43

$\sum_{j=43} a_{i j} x_{j}(t) \leq b_{i}(t) ; \quad i=27$

As inequações (30) e (31) tem o mesmo significado que (26) e (27), mas nesse caso trata-se de colhedelra para soja. 0 seu uso é limitado pela disponibilidade prévia mais o investimento, sen do que este por sua vez tem um limite superior.

\section{2 .4 .5 - Balanço de insumos variäveis}

Este é um conjunto de restrições que estabelece a cor respondēncia entre quantidade utilizada e quantidade comprada de fer tilizantes, corretivo e insumos modernos. Abaixo um único exemplo,pa ra corretivo que é o mais simples:

$$
\sum_{j=1}^{26} a_{i j} x_{j}(t)-\sum_{j=58}^{58} a_{i j} x_{j}(t) \leq 0 ; \quad i=28
$$

A quantidade usada ( $1^{8}$ termo) é menor ou igual à quan tidade comprada ( $2^{\circ}$ termo) no ano $\underline{t}$. Os demais insumos variáveis re feridos seguem o mesmo padrão. 


\subsubsection{6 - Balanço de produção, consumo e venda}

$\sum_{j=16}^{16} a_{1 j} x_{j}(t)+\sum_{j=60}^{60} a_{1 j} x_{j}(t) \geq \sum_{j=64}^{64} a_{i j} x_{j}(t)+\sum_{j=40}^{40} a_{i j} x_{j}(t)$,

$\operatorname{com} 1=33$,

$\sum_{j=40}^{40} a_{1 j} x_{j}(t) \geq b_{1}(t) \quad ; \quad 1=37$

Em (33) tem-se que a produção somada à quantidade com prada fora da propriedade, serão pelo menos iguais ao volume de ven das acrescido do consumo. O exemplo 1lustra o caso do arroz,mas é o mesmo para feljão, leite $C$ e milho, sendo que o consumo deste ült1mo reserva-se aos animals de serviço ou pecuária. Isto é também válido para o caso espectal de le1te $B$ que não faz parte dos ftens de consumo; nesse caso, em (33) apenas os primeiros termos de cada mem bro representariam a produção e venda, respectivamente.

Tratamento ligeiramente diverso ocorre com as culturas perenes, mas em essêncla trata-se do mesmo mecanismo de balanço entre produção e venda, tal como no caso de leite $B$, diferindo deste por apresentar várias etapas que correspondem aos estáglos de ma turação da cultura com diferentes nf́vels de produtividade.

A desigualdade em (34) estabelece que o consumo tem que suprir, numa proporção fixa, as necessidades do nümero de traba 1hadores famlliares. 
60.

\subsubsection{7 - Balanço de Pasto}

$$
\sum_{j=29}^{31} a_{1 j} x_{j}(t) \leq \sum_{j=32}^{33} a_{1 j} x_{f}(t) \quad ; \quad i=43
$$

A exigèncla em pastagens deve ser menor que a respec tiva disponibilidade.

$$
\text { 3.2.4.8 - Balanço das culturas perenes }
$$

$$
\sum_{j=19}^{26} a_{i j} x_{j}(t)=b_{1}(t) \quad ; \quad 1=44, \ldots, 51
$$

A equaçāo (36) traduz o fato que, desde que se procedeu ao plantio de culturas perenes em anos anteriores, e porque näo se Incorporou erradicaçāo, as ăreas correspondentes ao investimento Iniclalem $t-k$ permanecem constantes no ano $t_{-}$, cobrindo todos os estáglos de maturação das culturas.

\subsubsection{9 - Restrições de comportamento (coeficientes de flexibilidade)}

Os coeficientes de flexibilidade desempenham o 1mportante papel de explicitar, de modo mals ou menos rigoroso, o com portamento dos agricultores face às questões de risco, incerteza e ajustamento no tempo. Além dessas restrições, pode-se arrolar tambëm os limites superiores impostos à adoção de nova tecnologia, especlalmente em relaçāo à mecanizaçāo, já tratados quando dos comen- 
tários sobre os investimentos.

Mals detalhes da justificativa do uso dos coeficientes de flexibilidade e a mane1ra de calculá-los são dados na secção 3.2.5.8. De maneira geral, obedecem às seguintes sentenças:

$$
\begin{aligned}
& \sum_{j} a_{1 j} x_{j}(t) \leq b_{1}(t) ; \quad 1=52,54, \ldots, 88,90 \\
& \sum_{j} a_{i j} x_{j}(t) \geq b_{1}(t) ; \quad 1=53,55, \ldots, 87,89,91
\end{aligned}
$$

onde a f-ésima atividade produtiva representada no sistema (37) pode variar entre limites superiores e inferiores no ano $\underline{t}$.

\subsubsection{0 - Restrições não-negativas}

Estas restrições integram a própria estrutura do pro grama, visto que este näo permite uma atıvidade que possua valor ne gativo e, portanto, irreal.

$$
x_{j}(t) \geq 0 \quad ; \quad j=1, \ldots, 72
$$

\subsection{5 - As disponibilidades (RHS)}

Recorda-se que as disponibilidades (ou limites) do M.P.R., devem obedecer a

$$
b_{i}(t)=f_{1}\left[x+(t-1), b_{i}(t-1), c_{i}(t)\right],
$$

que é a equação geral do mecanismo recursivo. Este tem sua eficiên- 
cia explicativa diminuida quando se recorre ao vetor $c(t)=\left[c_{1}(t)\right]$ porque sua presença indica a inclusão de variáveis exógenas. A seguir tem-se uma exposição sobre como se obteve os limites significantes, excluídas as linhas de balanço.

\subsubsection{1 - Terra}

A limitação em terra fez-se com três tipos: (1) terras para culturas anuais; (2) terras para culturas perenes; (3) ter ras para pastagem. A quantidade de terra manteve-se constante ao longo de todo o período, e seu cálculo foi efetuado com o auxilio dos questionários do IEA (f́tem "Utilização das Terras"), corrigidos por dados preliminares do projeto Zoneamento Agrícola do Estado de São Paulo, IEA, 1974; os questionários informam sobre os estratos de área, ao passo que os dados do projeto o fazem para a área total da DIRA.

\subsubsection{2 - Mão-de-obra}

Este ftem foi dividido em três tipos: (1) mão-de-obra familiar; (2) mão-de-obra residente; e (3) mão-de-obra contratada. A separação entre as duas primeiras objetiva distingui-las no consumo dos produtos alimentares, e nas oportunidades de emprego dentro e fora da propriedade, atividade permitida somente aos trabalhadores familiares. Existe um diferencial de salário entre as categorias (2) e (3); o custo de oportunidade para a categoría (1) é igual ao salário percebido pela categoria (2). 
A mão-de-obra familiar a residente somadas formam a categoria "Trabalhadores Residentes", do Prognóstico Agrícola 77/78, a cujos dados aplicou-se a fórmula:

$$
\text { T.R. }(1976)=\text { T.R. }(1971)[1+\delta]^{5}
$$

onde, T.R. = $n^{8}$ de "Trabalhadores Residentes";

$$
\delta=\text { taxa de crescimento (negativa, no caso). }
$$

Usando-se $\delta$ expandiu-se os dados para os anos extremos: 1970 e 1977. A essa série temporal aplicou-se um pequeno desconto por causa de algumas atividades excluídas.

A separação entre mão-de-obra familiar e residente fez-se através da média dos percentuais de familiares dos proprietá rios na população trabalhadora residente, obtida a cada ano nos ques tionários do IEA, para cada estrato (grupo de propriedades).

A mão-de-obra famıliar dividiu-se em três sub-períodos, mas a mão-de-obra residente fol imobilizada durante todo o ano agrícola.

A respectiva equação recursiva assumiu a seguinte for ma :

$$
\lambda[M .0 .(t)]=[(1+\delta) M . O .(t-I)] \lambda
$$

onde: M.O. = $n^{8}$ de trabalhadores (familiares ou residentes) no sub-período;

$\delta$ = taxa de crescimento dada em (39);

$\lambda=$ coeficiente de conversão (dias de trabalho por sub-períodol. 
Para mão-de-obra contratada pressupôs-se oferta perfeitamente elástica durante todo o horizonte, quer dizer, não houve IImites à sua aquisição, conforme llustra a figura abaixo.

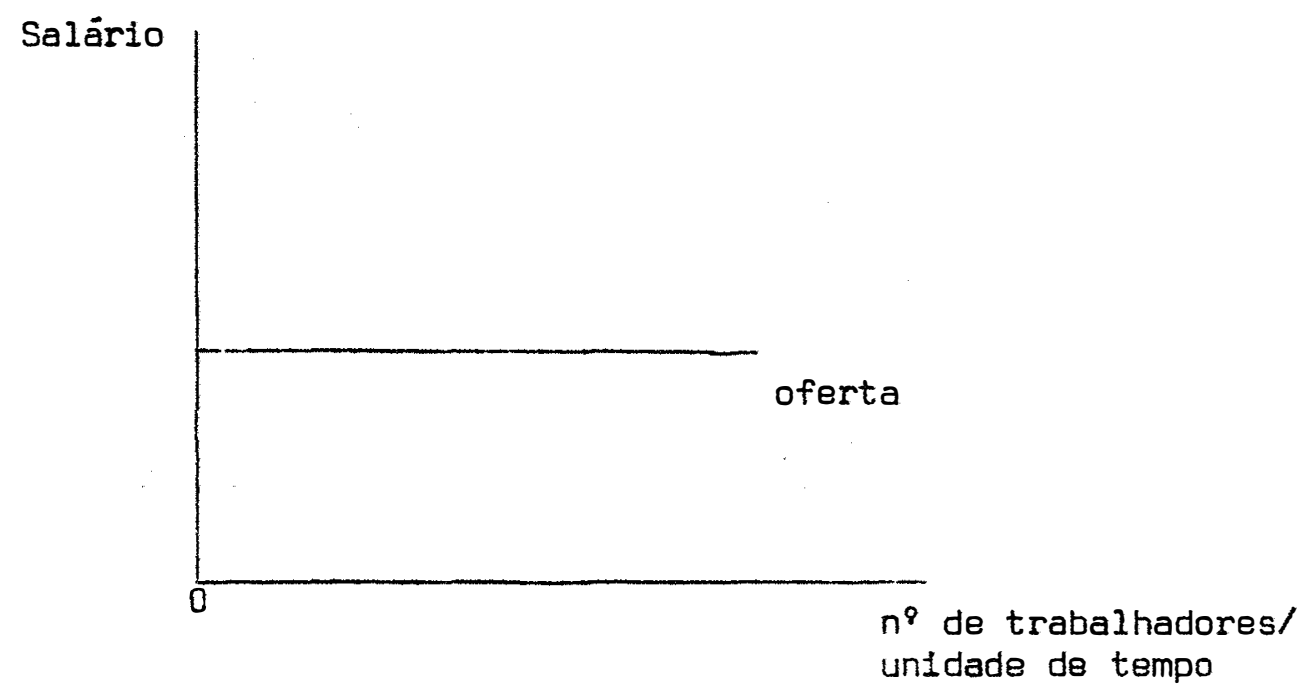

Figura 4 - Oferta regional de trabalhadores contratados.

A colocaçāo de Ilmites para mão-de-obra contratada por estrato não tería sentido porque a mobilidade da força de traba Iho temporária á grande na regiäo, e dificilmente se conseguiria 11 mites adequados. Mesmo para a competição røgional, a fixação de dis ponibilidades não sería fäcil porque ter-se-ia que contar com alguns coeficientes migratörios inter-regiões, além das taxas de cres cimento agrícola populacional e de urbanização regionais.

Outros itens do modelo, principalmente oferta de insumos variáveis, seguiram o mesmo padräo de ofertas perfeitamente elásticas, mas nesses casos a suposição não compromete tanto quanto no caso de mão-de-obra. Um meio de superar tais obstáculos é proje- 
tar, ou utilizar, funções de oferta välidas para a região, ou ainda elaborar equações de tendência para a quantidade de insumos.

\section{2 .5 .3 - Caixa (capital de giro)}

A disponibilidade de caixa foi calculada como uma pro porção da receita bruta (para cada grupo de propriedades) do ano agrícola anterior, segundo o critério recursivo:

$$
C X(t)=C X(t-1)+\delta[\operatorname{RET} *(t-1)]-\sum_{n=2}^{6}[O F(t-n)]
$$

com $n=2, \ldots, 6$, desde que $n \in t=1970 / 71, \ldots, 76 / 77$, e

onde: $C X=$ disponibilidade de capital de giro (caixa);

$\delta=$ taxa de poupança do estrato;

$R E T=$ retorno (receita liquida observada):

OF = obrigações fixas;

* = indica valores da solução ötima.

A taxa de poupança $\delta$ é uma medida do quanto da renda é retida após o dispêndio geral com bens de toda a espécie consumi dos na propriedade. O RETORNO (RET) é substituto da RECEITA (função objetivol mas com as receltas reais ao invés das esperadas das culturas, suprimindo as contribuições das atividades de plantio de cul turas perenes e investimento em maquinaria (porque traduzem tão somente uma medida de decisão sobre o acionamento dos vetores respectivos), e as taxas de juros para crédito de investimento. 
As obrigaçöes fixas referem-se ao pagamento de juros simples mais amortizaçōes do principal (em 7 parcelas) dos investimentos em maquinaria com prazo de carência de 2 anos. Assumiu-se a pressuposição que no inf́cio do horizonte de planejamento não existiam obrigaçōes fixas, por falta de dados a esse respeito.

\section{$3 \cdot 2 \cdot 5.4$ - Crédito}

As restriçöes de crédito para cada ano (de custelo e investimento\} foram tomadas exogenamente. A partir do trabalho de ARAUjo (1977), exezutado com dados depurados dos questionários do IEA, estabeleceu-se uma proporcionalidade em termos de cruzeiros de crédito por hectare (devido à estratificação que não era inteiramen te compativell chegando-se a um percentual sobre quanto de crédito receberia cada grupo de propriedades. Essa porcentagem foi aplicada às séries disponfveis sobre o montante do crédito destinado à DIRA publicados no boletim Informaçōes Econômicas.

A exemplo do ocorrido com mão-de-obra tentou-se um "desconto" do crédito de custeio que iria para aquelas atividades ex cluídas do modelo. Assinale-se que nesse caso o "desconto" foi mais rigoroso. Quanto ao crédito para investimento não houve "descontos", mas como um grande número de atividades de investimentos não foram consideradas, teve-se, efetivamente, oferta ilimitada desse tipo de crédito.

Lembra-se que tanto crédito como mão-de-obra e oferta de maquinaria deveriam originalmente sofrer competição regional. 


\section{2 .5 .5 - Mäquinas}

As disponibilidades do complexo trator-implementos também dividiu-se em trēs sub-períodos para atender a momentos de pico na sua utilização. A equação recursiva encontra-se abaixo:

$$
\operatorname{TRT}(t)=\operatorname{TRT}(t-1)+[\operatorname{MINVTRT} *(t-1)] \lambda
$$

onde: TRT = disponibilidade de trator-implemento (em dias-máquina): MINVTRT = investimento em trator-implemento (em número de unidades);

$\lambda=$ coeficiente de conversão (dias de uso no sub-período).

Com respeito à depreciação física para as máquinas,o expediente utilizado foi simplesmente tomar a taxa liquida de crescimento potencial máximo para aquisição de recursos semi-fixos no curto prazo. Essa taxa representa o comportamento dos agricultores face à adoção e difusão de nova tecnologia (no modelo as mudanças tecnológicas referem-se principalmente a diferenças no grau de meca nização); por outro lado, há que se considerar um limite para a ofer ta desse insumo a curto prazo.

0 procedimento adotado foi o seguinte:

$$
\operatorname{LMSPTRT}(t)=[1+\delta]\left[\frac{\operatorname{TRT}(t-1)}{\lambda}+\operatorname{MINVTRT} *(t-1)\right]
$$

onde: LMSPTRT $(t)$ = limite máximo de investimento em número de unida des;

$\delta$ = taxa de crescimento potencial mäximo. 
68.

Os demais símbolos têm o mesmo significado que em (42). A taxa $\delta$ calculou-se como a taxa geométrica de crescimento do número de tratores (transformados em equivalente de $61 \mathrm{HP}$ ), a partir dos dados brutos constantes dos questionários do IEA para o intervalo 1970 a 1975 .

Para a colhedeira de soja procedeu-se de igual mane1

ra.

\subsubsection{6 - Animal de trabalho}

Pelo decréscimo constante do nümero de animais de tra balho na agricultura da região, novamente utilizou-se da taxa geomé trica para se estimar exogenamente a disponibilidade de animal de trabalho. Neste caso tem-se:

$$
\lambda[\operatorname{LMSPANT}(t)]=[(1+\delta) \operatorname{LMSPANT}(t-1)] \lambda
$$

onde: LMSPANT $=n^{2}$ de animais de trabalho;

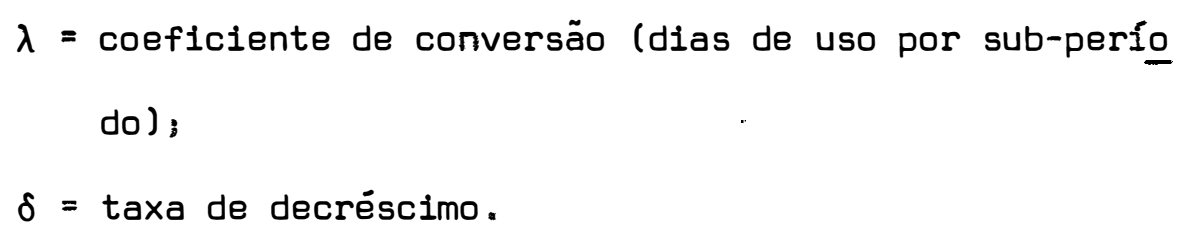

\subsubsection{7 - Culturas perenes}

O mecanismo recursivo para os limites das atividades intermediárias que cobrem os vários estágios de maturação das culturas perenes já foi parcialmente explicado em outras secções.

Para o café ter-se-ia: 


$$
\begin{aligned}
& \operatorname{TFCFPRD}(t)=\lambda[\operatorname{TFCFPRD}(t-1)]+\operatorname{TFCF} 3 A N(t-1) \\
& \operatorname{TFCF3AN}(t)=\operatorname{TFCF2AN}(t-1)
\end{aligned}
$$

até

$$
\operatorname{TFCFIAN}(t)=\operatorname{CAFINV*}(t-1)
$$

onde: TFCFPRD = hectares de café em produção;

$\lambda$ = taxa de depreciação linear (fração da vida ūtil da cultura):

TFCF3AN = hectares de café com 3 anos após o plantio; TFCF2AN = hectares de café com 2 anos após o plantio; TFCFIAN = hectares de café com l ano após o plantio: CAFINV = hectares de café investidos (plantados);

$$
\text { * = solução ötima. }
$$

O sistema de equações visto em (45) simplesmente garante a transferência dos vários anos para o seguinte deixando sujeitos aos coeficientes de flexibilidade os anos de plantio quando se decide sobre o investimento em culturas perenes.

0 mesmo tipo de tratamento foi dispensado a citrus.

\subsubsection{8 - Coeficientes de flexibilidade}

Os coeficientes de flexibilidade, encarregam-se de garantir que a ärea plantada (ou as unidades-animal) permaneçam den tro de um intervalo determinado pelos respectivos limites inferiores e superiores calculados a partir da solução do ano anterior,con forme se vê abaixo, exemplificado para o caso do milho, com duas tec nologias: 


$$
\sum_{j=14}^{15} a_{i j} x_{j}(t) \geq(1-\beta) \sum_{j=14}^{15} x_{j}^{*}(t-1) ; i=71
$$

em que a i-ésima linha estabelece o limite mínimo da j-ésima atividade no ano $\underline{t}$, com $\beta$ sendo o coeficiente inferior.

Da mesma forma:

$$
\sum_{j=14}^{15} a_{1 j} x_{j}(t) \leq(1+\alpha) \sum_{j=14}^{15} x_{j}^{*}(t-1) ; i=70
$$

em que a i-ésima linha estabelece o limite máximo da j-ésima atividade no ano $t$, com $\alpha$ sendo o coeficiente superior.

0 maior ou menor rigor nas estimativas desses coeficientes é questão mais de padronização do que propriamente de preci são, pois sua importância comprova-se na medida em que contribui mais, ou menos, para explicar a realidade, que é seu único teste. O essencial é ter em mente o que se está querendo representar com sua utilizaçäo: é evidente tambëm que o seu emprego näo deve variar período a período, ao contrário, sua validade deve estender-se ao longo do horizonte de planejamento. Em suma, a escolha é feita exante e segundo os critérios mais razoáveis tendo-se em vista o fim pretendido. Assim, as maneiras usuais de cálculo resumem-se em:

\section{(1) Mëtodo das taxas mëdias:}

Utiliza-se da taxa média histórica de variação, tomando separadamente os limites superiores e inferiores. De acordo com a notação utilizada anteriormente, o coeficiente $\alpha$ superior seria o valor absoluto do primeiro termo de (48), e B seria o valor ab 
soluto do primeiro termo em (49).

Há varlações nesse método, uma das quals sugere acrescentar (ou subtral $r$ ) da varlação mëdia o desvio padrão do respectivo aumento (ou diminutção). Qutra ainda sugere que se tome ao Invés da variaçäo médıa, a variação máxima tanto superıor como infe rior.

$$
\begin{aligned}
& \frac{1}{n} \sum_{t=1}^{n} \frac{x_{j}(t)-x_{j}(t-1)}{x_{j}(t-1)} \geq 0 \\
& \frac{1}{m} \sum_{t=1}^{m} \frac{x_{j}(t)-x_{j}(t-1)}{x_{j}(t-1)} \leq 0
\end{aligned}
$$

(11) Estimativa dos minimos quadrados:

$$
\begin{aligned}
& x_{j}(t)=\gamma_{1} x_{j}(t-1) \\
& x_{j}(t)=\gamma_{2} x_{j}(t-1)
\end{aligned}
$$

Nesse caso, a equação (50) reune os pontos acima de uma reta de 45 graus no plano ärea em $t$ versus área em $t-1$, sendo que a estimativa de $\gamma_{1}$ através de minimos quadrados fornece indiretamente $\alpha$ (porcentagem de variação para cima). Do mesmo modo, em (5I) tem-se os pontos abaixo de reta de 45 graus, sendo que $\gamma_{2}$ permite ob ter-se B (porcentagem de variação para baixo). Alternativamente, po. de-se estimar uma ünica reta com todos os pontos no plano considera do, quando a seria igual a $\beta$; ou alnda acrescentar novas variáveis independentes em (50) e (51) que tenham poder de explicação. 


\section{(III) Mëtodo dos pontos selecionados}

E um método mais simples, usado quando o nfvel da atividade no decorrer do tempo apresenta forte tendência numa direção (para cima ou para baixo), e muito útil quando há ausência de dados.

$$
x_{j}\left(t_{n}\right)=x_{j}\left(t_{0}\right)[1+\delta]^{t_{n}-t_{0}}
$$

onde $\delta$ em (52) é a taxa geométrica de crescimentos no caso, o valor absoluto de $\delta$ tomará o lugar de $\alpha$ ou $\beta$ anteriores.

Para a obtenção dos coeficientes de flexibilidade usados neste trabalho, simplesmente escolheu-se pontos médios entre aqueles acima e abaixo da linha de 45 graus no espaço área em $t$ e área em $t-1$, para os coeficientes $\alpha$ e $\beta$, respectivamente; isto se aproxima do método (I). A escolha descartou automaticamente os extre mos que não parecem adequados porque permitem rápidas espectalizações.

Devido à falta de informações para o ano de 1969/70, usou-se os dados de 1970/71 para o cálculo dos limites inferiores e superiores do ano inicial, ou seja, assumiu-se a pressuposição que as áreas plantadas (ou unidades-animal) em 1969/70 permaneceram as mesmas no ano seguinte. Para o caso dos limites de comportamentonos investimentos em máquinas, utilizou-se do método (III), em que $t_{n}=$ $=1975$ e $t_{0}=1970$. 


\section{3 - A Estratificação e Extensão do Modelo}

A região fol estratificada, segundo o tamanho das propriedades, como se segue:

(a) Estrato I: de 3,1 a 10,0 hectares (pequeno ou inferior)

(b) Estrato II: de 10,1 a 100,0 hectares (médio ou intermediário)

(c) Estrato III: acima de 100,0 hectares (grande ou superior)

Originalmente pensou-se em trabalhar com quatro estratos de área porque na região prevalece propriedades de pequenas a médias com maior frequêncla. Porēm isso não se tornou necessárío, porque com os três estratos de área finalmente estabelecidos, teve-se material suficiente para os objetivos pretendidos. Resta afirmar que as denominações dos estratos atuais são apenas e simplesmen te designativas, e não pretendem corresponder a uma dada classifica ção rígida para as propriedades da região.

A razão de se proceder à estratificação é uma tentativa de resolver parcialmente o problema da agregação. Estratifica-se, em ültima análise, porque espera-se que os estratos de área se jam mais homogèneos do que a região inteira. Para tanto são necessárias pressuposições tão mais restritivas quanto maior for a diver sidade no sub-agregado.

Usa-se muitas vezes a expressão "propriedade típica" para significar que aquele conjunto determinado de propriedades age como se fosse uma ünica, grande e vasta propriedade, porque a deci- 
são sobre ela é tomada uniformemente, dada sua estrutura técnica e institucional.

Para serem agregadas em um mesmo grupo, as proprieda des devem possuir:

(a) quantidades proporcionalmente iguais de recursos disponiveis:

(b) mesma expectativa de receita 1fquida: e

(c) Idênticos coeficlentes técnicos.

Diz AHN (1972): "Para propriedades que se encontram sob as mesmas condições exógenas numa zona relativamente homogênea quanto ao clima e topografia, suas decisões formam um agregado que representa seu comportamento e, portanto, sua resposta produtiva. Entretanto, a menos que as unidades produtivas sejam também razoavelmente homogêneas com respeito às suas condições econômicas endógenas, especialmente quanto à disponibilidade de recursos, a agrega ção pode levar - e leva - a erros sérios na análise regional".

A estratificação serve para a diferenciação principalmente da composição das atividades, das mudanças na proporcionalidade dos fatores, e consequentemente, das mudanças tecnológicas ao longo do período.

Os coeficientes técnicos de produção da região manti veram-se, por pressuposição, Inalterados, além de serem também bas camente os mesmos para todos os estratos: as diferenças entre eles se reduzem apenas à exclusão ou 1 nclusão de poucas atividades. A 
questão da constância dos coeficlentes técnicos resume-se no fato que, embora se possa imaginar um sem número de combinações técnicas na região, dificilmente seria viāvel sua incorporaçäo, ou pela falta de dados disponíveis ou pela extensão demasiada que se daría a matriz em vista da grande variedade das atividades que a integram. Seria necessário um trabalho especial de campo que estava totalmente fora das cogitações originais. Outro fator que pesou nessa decisäo é creditado à estabilidade que se esperava para a região num pe ríodo exíguo de 7 anos; supôs-se que todas as alternativas técnicas de que se dispunha já se encontravam à disposição no ano inicial, o que não é difíc1l de se aceitar.

As justificativas para os mesmos coeficientes técnicos nos três estratos envolvem questões de maior profundidade. A raiz do problema situa-se na questão dos retornos à escala que se constitui em ponto controvertido no caso da agricultura. A existência de economia interna de escala, segundo alguns autores 4 , parece ser determinada multo mais pelo tipo de tecnologia empregada que, por seu turno, depende diretamente da proporcionalidade entre os fatores de produção $e$, portanto, de sua disponibilidade - que propriamente do tamanho físico da propriedade.

Naturalmente, na programação Iinear o retorno à esca la é constante para cada processo (tecnologia) mas aqui trata-se de verificar se o tamanho das propriedades implicaria em diferentes pro

4/ SCHULTZ, RAUP e outros, citados por AHN (1972). 
cessos conforme seu crescimento em área disponf́vel. Em outras palavras, se propriedades maiores deveriam possuir processos que diferissem daqueles empregados nas propriedades menores. Com exceção cla ra de alguns casos, como utilização de maquinaria, isto não ä neces särio.

Não há dúvidas de que o fator terra, por exemplo, pode apresentar retornos decrescentes, constantes e crescentes, dentro de intervalos, conforme sua qualidade, mas não existem indícios seguros de que grandes propriedades tenham maior proporção de terras boas que pequenas propriedades. E mesmo nesse caso não se esclarecia inteiramente' la menos que todas as terras boas estivessem em mãos dos grandes proprietários) a controvérsia da economia de escala referida tão somente ao tamanho das propriedades. A influência exclusiva destas não parece destruir o realismo de iguais coeficien tes técnicos entre os estratos quando se parte de um agregado,e tam bém de um módulo mínimo alcançado na amostra (maior que 3,0 hectares).

Em sintese, a discussão tenta mostrar que há iguais oportunidades entre os estratos no sentido da possibilidade de aces so a tecnologias disponíveis, tornadas enfim desiguais na medida em que a disponibilidade dos e proporcionalidade entre os fatores de produção corresponder a tal desigualdade.

Mesmo não se procedendo à competição regional, senão de forma indireta, indicar-se-á um modo como isto pode ser efetuado tomando-se o exemplo do princípio de decomposição utilizado por AHN 
(1972). O princípio de decomposição pode ser definido como um processo de partição de matrizes que permite a agregação dos estratos, mantendo-se a estrutura da decisão técnica e institucional de cada um. Trata-se de se efetivar a competição regional por recursos tais como os serviços da mão-de-obra contratada, o crédito, etc.

Tome-se o exemplo de uma região que foi dividida em trés estratos de área chamados dos pequenos, médios e grandes, para os quais se utilizará das letras $p, m$ e g, respectivamente, além da letra r para se referir à região. A figura abaixo, extraída do próprio AHN (1972), mostra a estrutura do principlo de decomposição.

Função-objetivo regional

Matriz insumo-pro duto para cada tî $\rightarrow$ po de estrato

Restrições Regionais

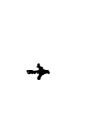

\begin{tabular}{|c|c|c|c|}
\hline$z_{j}^{p}(t)+z_{j}^{m}(t)+z_{j}^{g}(t)$ & $R H S$ \\
\hline$A_{i j}^{p}(t)$ & 0 & 0 & $\leq B_{i}^{p}(t)$ \\
\hdashline 0 & $A_{i j}^{m}(t)$ & 0 & $\leq B_{i}^{m}(t)$ \\
0 & 0 & $A_{i j}^{g}(t)$ & $\leq B_{i}^{g}(t)$ \\
\hdashline$R_{k j}^{p}(t)$ & $R_{k j}^{m}(t)$ & $R_{k j}^{g}(t)$ & $\leq B_{i}^{r}(t)$ \\
\hline
\end{tabular}

Figura 5 - Arranjo das matrizes para a competiçäo regional entre os sub-agregados.

Onde: $Z_{j}(t)$ acompanhado da respectiva indicação representa o retor no lfquido total de cada estrato: $B(t)$ as disponibilidades; e $A_{i j}(t)$ a matriz total dos coeficlentes tëcnicos e institucionais. 


\section{RESULTADOS E DISCUSSÃO}

\section{1 - Uso da Terra}

A distribuição da terra efetivamente utilizada mostra que no primeiro estrato de àrea (pequenos produtores), a terra tipo I (culturas anuais) foi inteiramente tomada desde o ano agríco la inicial de 1970/71, representando $45 \%$ da ärea total, seguida da terra tipo II (culturas perenes) com 24\%, e da terra tipo III (pastagens) com 31\%. Ao final do período (1976/77), a participação de cada tipo situa-se em torno de $32 \%, 39 \%$ e $29 \%$, respectivamente. Nota-se que, ao somar-se as terras dos tipos I e II como sendo de "cul turas", a sua participação relativa permanece a mesma no perfodo,em torno de $70 \%$.

No segundo estrato de área (médios produtores), terra I participa, no inf́cio do perfodo, com 40\%, seguida de terra II com $13 \%$, e terra III com $47 \%$. Ao final do perfodo, os valores são, 
respectivamente, $35 \%, 21 \%$ e $44 \%$. Há ligeira diminuição relativa de pastagens, e as terras para culturas anuais atingem o limite disponível no ano de $1973 / 74$.

Finalmente, no terceiro estrato de ärea lgrandes pró dutores\}, a sequência é $26 \%, 8 \%$ e $66 \%$, no inf́cio, para alcançar $30 \%$, $14 \%$ e 56\%, no final do perfodo, para as terras tipo I, II e III, res pectivamente. Neste estrato não se atinge o limite para terra tipo I. E grande a participação de pastagens, embora decresça essa impor tância, em termos relativos, durante o período.

o declínio relativo do conjunto das culturas anuais no primeiro e segundo estratos explica-se, evidentemente, pelos limites atingidos. No caso das culturas perenes, seu crescimento se deve tanto à disponibilidade de terras como pelo modo de sua incorporação, que parece beneficiar essas culturas: além disso, os coeficientes de flexibilidade nesse caso foram dos mais elásticos, e houve também ausência de erradicação.

A exceção de terra $I$, os demais tipos de terra não atingiram seus limites respectivos. Na terra tipo II incluem-se apenas café e laranja, e sua ocupação é muito baixa: nos três estratos de ärea, coincidentemente, cerca de $45 \%$ do total disponível dessa categoria são utilizadas, em cada um deles. Para a terra tipo III,o limite é flexível porque havia a possibilidade de transferência das atividades af realizadas para as terras que restaram de culturas pe renes, de acordo com as matrizes construídas. 
Observando-se a Tabela 3, e as Figuras 6, 7, 8 e 9, sobre o aproveitamento da terra, vê-se que é crescente o seu uso em todos os estratos e para todas as categorias, com exceção de terra tipo III. As quantidades e categorias de terras disponf́veis para utilização foram tomadas com base num critério misto de seu uso efetivo e capacidade de uso.

Em sintese, tem-se os seguintes problemas relacionados ao tratamento dado às terras:

a) houve flexibilidade no uso de alguns tipos de terras (II e III) porque na agregação foram excluídas certas atividades como a dos hortigranjeiros, reflorestamento, atividades de destoca e limpe za do terreno, etc., devido à inviabilidade imediata de se montarma trizes do porte e nfvel de detalhes para incluf-las;

b) o procedimento na classificação das terras limitou-as a pou cas categorias, e isto levou a que se tivesse restrições nas terras para culturas anuais;

c) a escassez de alternativas tecnológicas agravou o problema do uso da terra I ao mesmo tempo que resultou na inflexibilidade no uso dos demais recursos.

Estes pontos, principalmente o ültimo, serão confirmados adiante, nas demais secções do capitulo. 


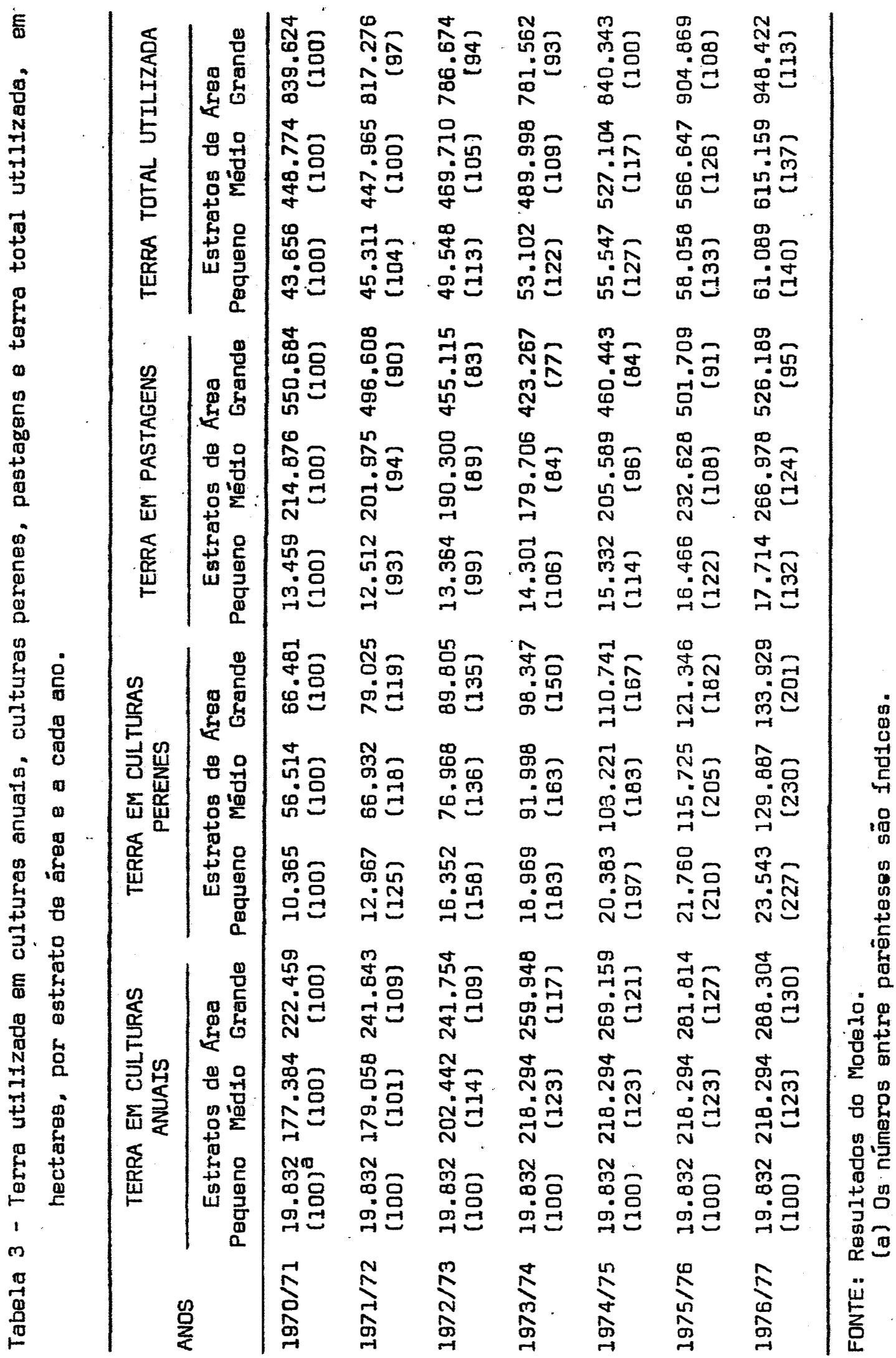




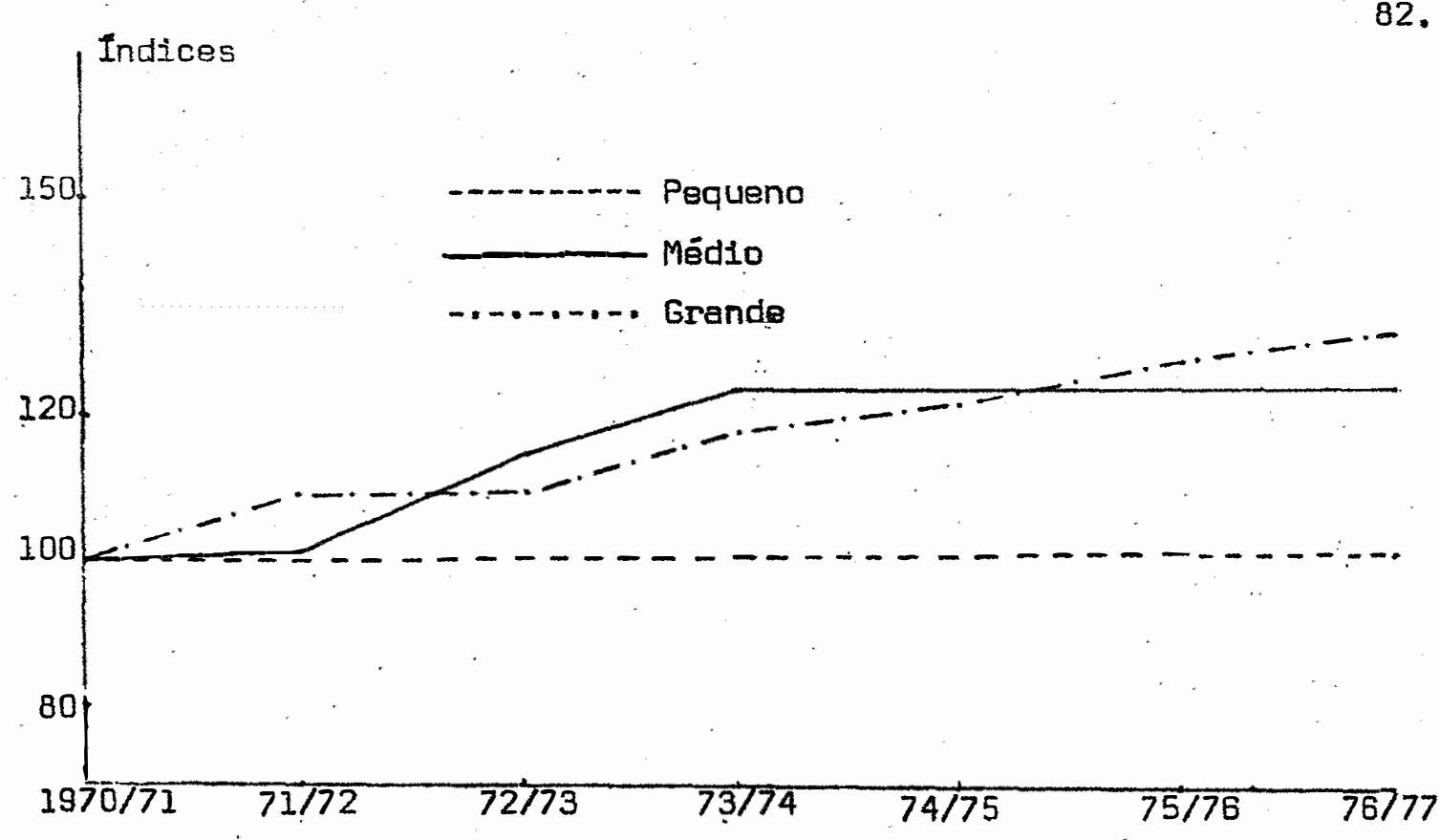

Figura 6 - Terra utilizada en culturas anuais FONTE: Resultados do Modelo.

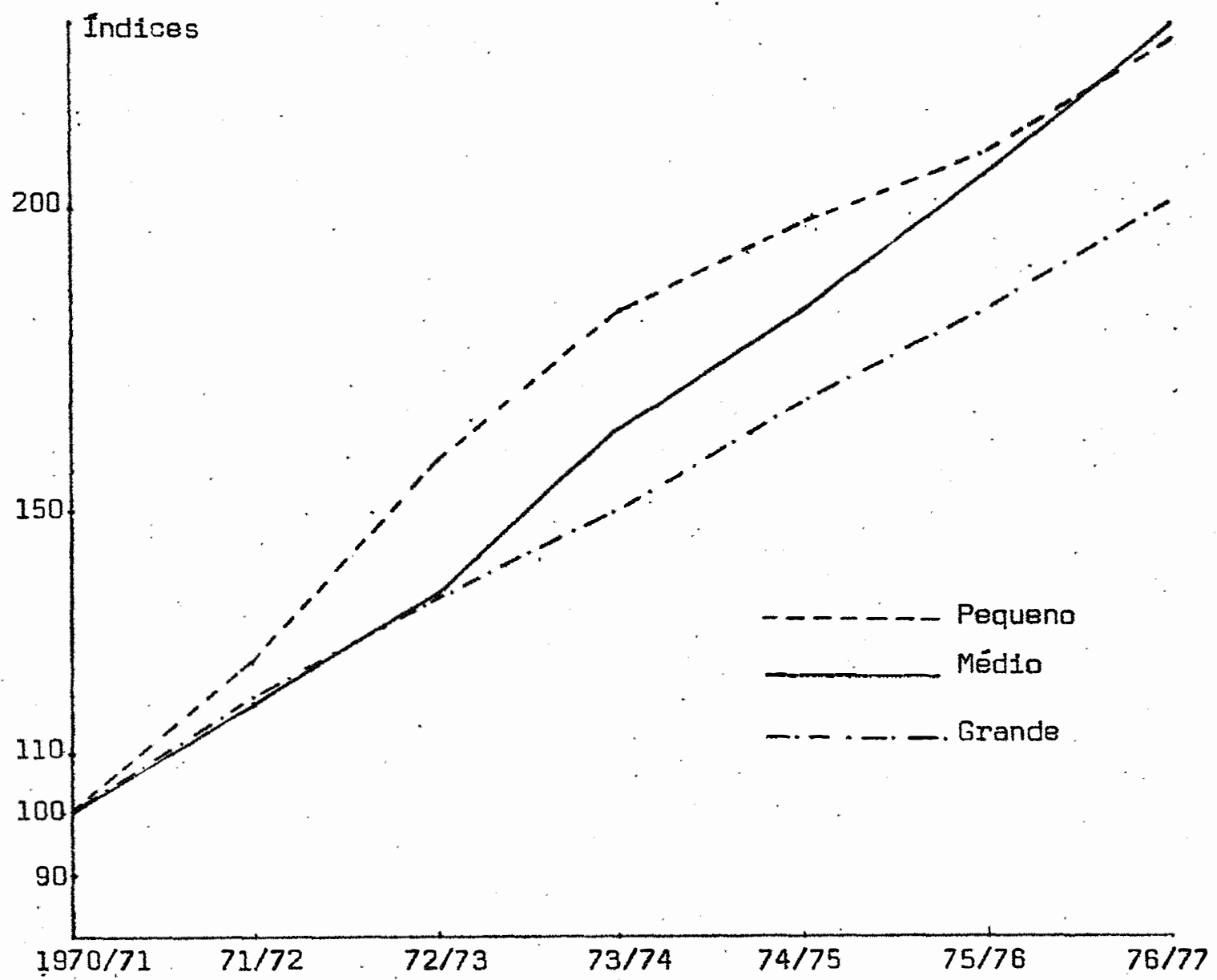

Figura 7 - Terra utilizada em culturas perenes. FONTE: Resultados do Modelo 


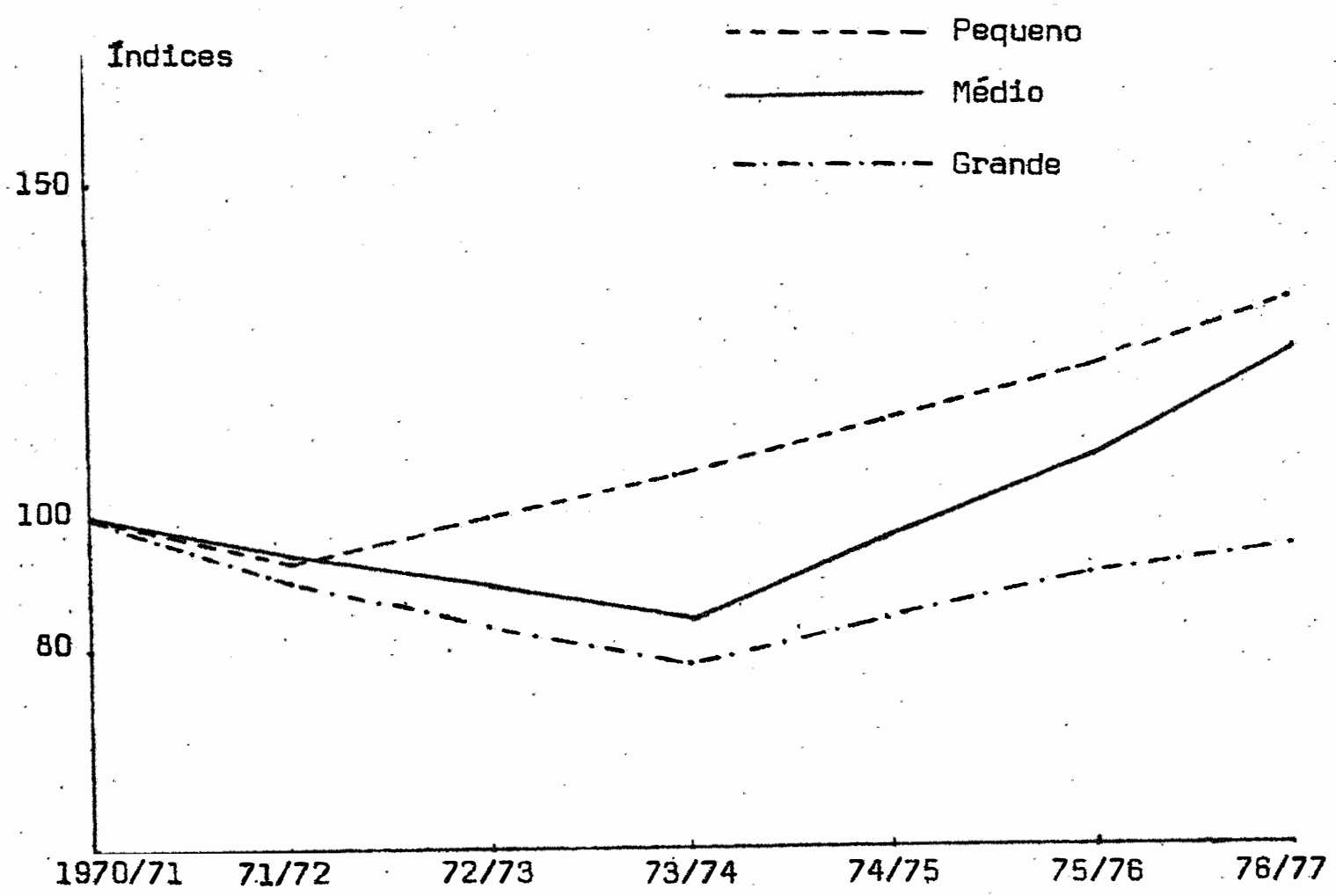

Flgura 8 - Terra utilizada em pastagens.

FONTE: Resultados do Modelo.

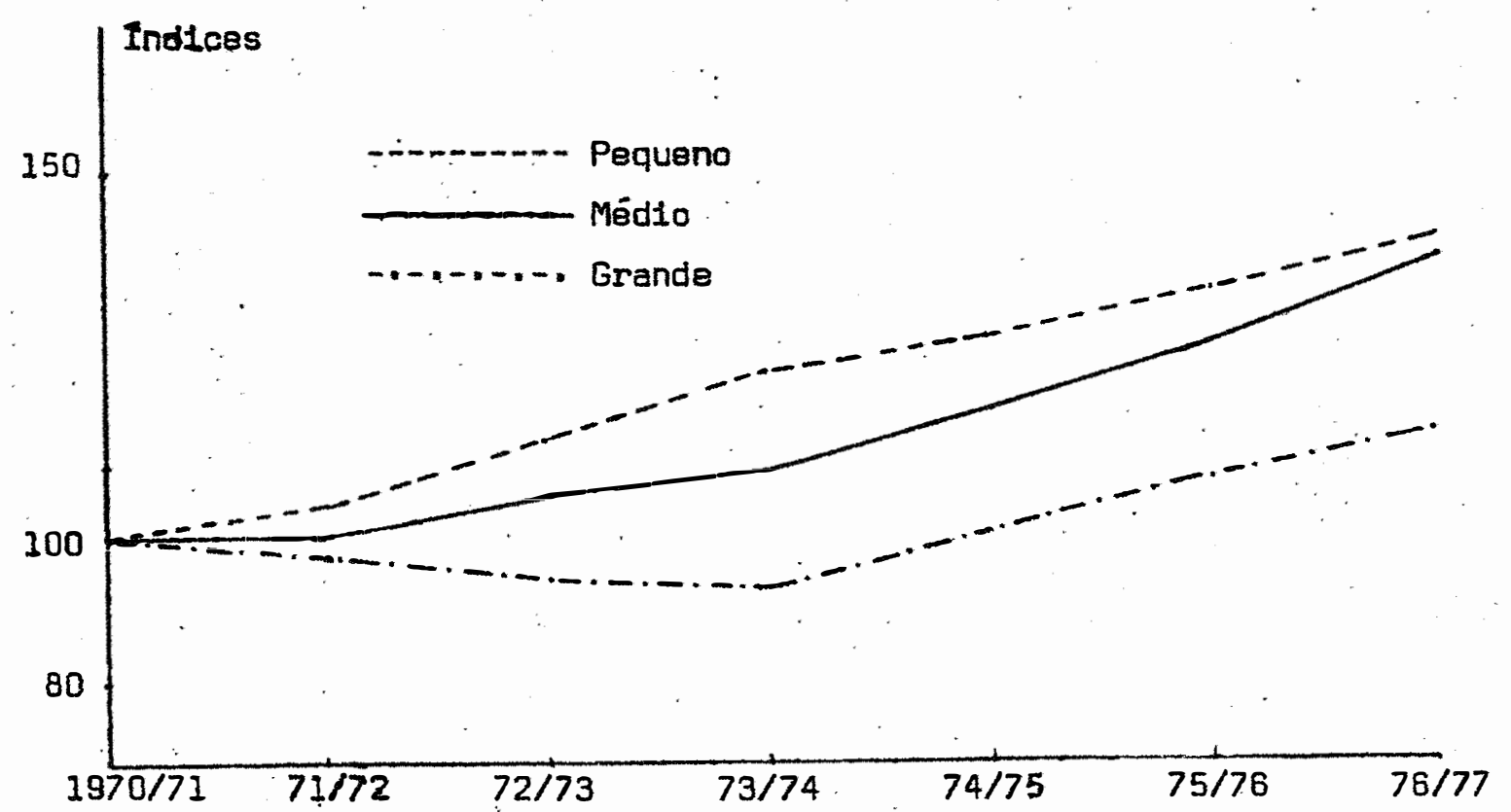

Figura 9 - Térsa total utilizada.

FONTE: Resultados do Modelo. 


\section{2 - Composição das Atividades}

\subsection{1 - Culturas anuais e perenes}

No primeiro estrato é onde estão mais flagrantes as mudanças na composição das atividades porque o limite de terra para culturas anuais é atingido desde o perílodo inicial. Tomando-se os anos extremos, tem-se que as culturas que aumentaram sua área plantada foram, em ordem decrescente do indice de aumento $(1970 / 71=100)$, e segundo os resultados do modelo: cana (390), café (245), laranja (218) e feljão da seca (168). As que diminuiram foram: arroz (26), milho (38), batata da seca (45), feifão das águas (53), mandioca (85), e algodão (91). Batata das águas permaneceu com área constante.

Para o segundo estrato as seguintes culturas aumenta ram: café (295), cana (223), laranja (211), feijão das águas (187), algodão (130), e tomate (118). E diminuíram: batata da seca (41), mi Iho (68), arroz (73), feijão da seca (92), batata das äguas (94), e soja (96) 5/. Mandioca permaneceu com ärea constante.

Quanto ao terceiro estrato aumentaram: soja (396), fei jão das äguas (231), algodão (230), café (228), laranja (169), cana (146), feijão da seca (130), e tomate (108). Diminuíram: batata da seca (41), milho (68), e arroz (73). Mandioca e batata das águas per maneceram com áreas constantes.

5/ Para soja, neste estrato, $1973 / 74=100$ 
As culturas que francamente diminuiram em todos os es tratos, a partir das qua mais o fizeram, foram batata da seca, miIho e arroz, nesta ordem no segundo e terceiro estratos, e em ordem invertida no primeiro estrato.

As culturas francamente ascendentes foram cana, café. laranja e algodão, excluindo-se esta ültima no primeiro estrato. De um modo geral maior número de culturas cresceram em área plantada no perfodo, em proporção direta com o tamanho das propriedades ex presso nos estratos de área.

\subsection{2 - Pecuäria e pastagens}

No caso de pecuária e pastagens houve um crescimento moderado no perfodo, com exceção da produção de leite $B$, quando se comparam os anos extremos. Esse crescimento gradual contrasta com o crescimento vertiginoso de culturas perenes.

Pecuária bovina de corte (ver Figura 10) aumentou no primeiro estrato de $12 \%$, de $9 \%$ no segundo estrato, e de $16 \%$ no terceiro estrato. Pecuária de leite B (ver Figura 11) apresentou crescimento de $342 \%, 273 \%$ e $44 \%$ no perfodo, para o:primeiro, segundo e terceiro estratos de área, respectivamente. Pecuária de leite Clver Figura 12), do mesmo modo, cresceu de $13 \%$, $107 \%$ e $1 \%$. 


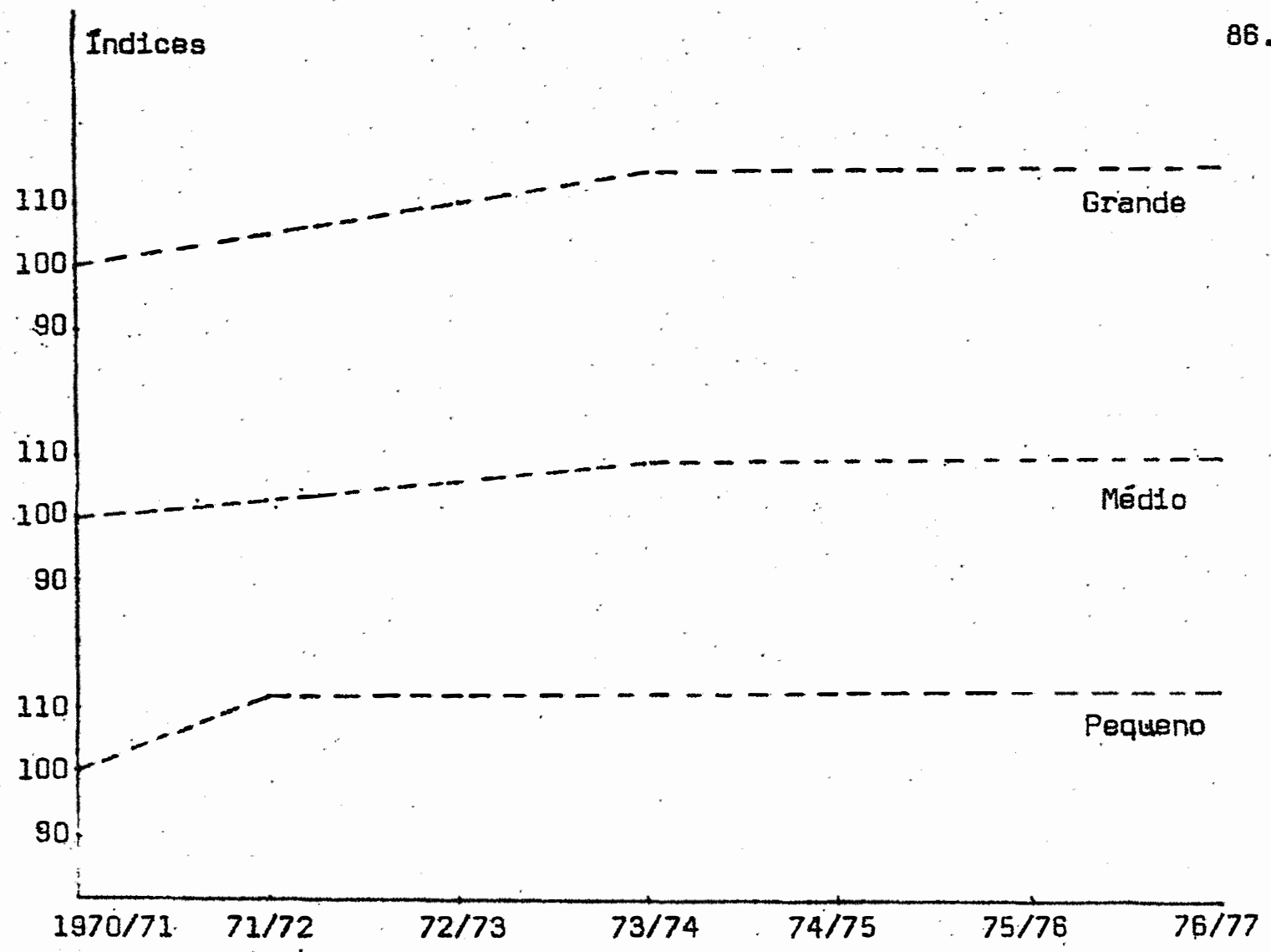

Figura 10 - Indices de crescimento de pecuárja bovina de corte.

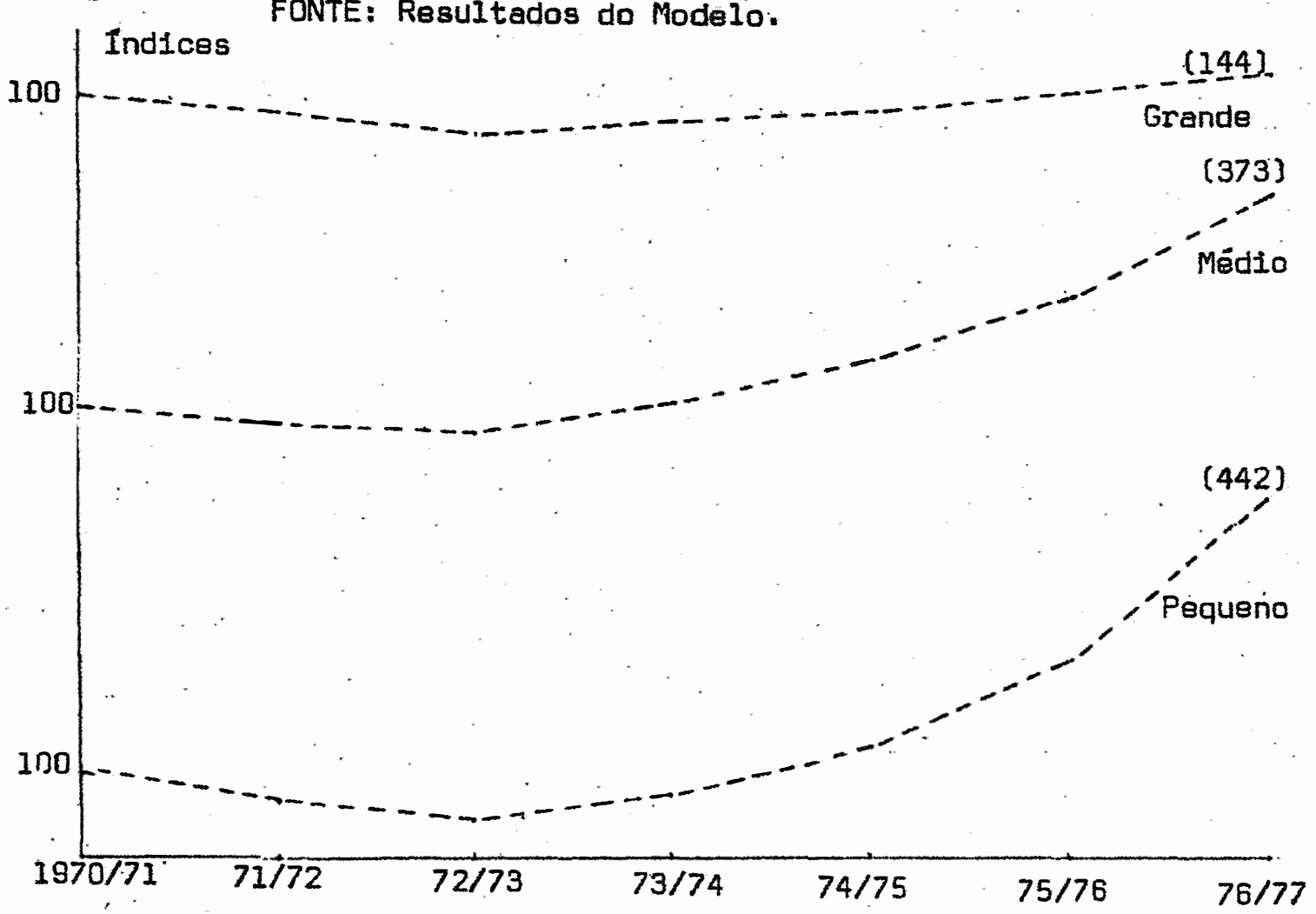

Figura 11 - Indices de crescimento de pecuária de leite $B$. FONTE: Resultados do Modelo. 


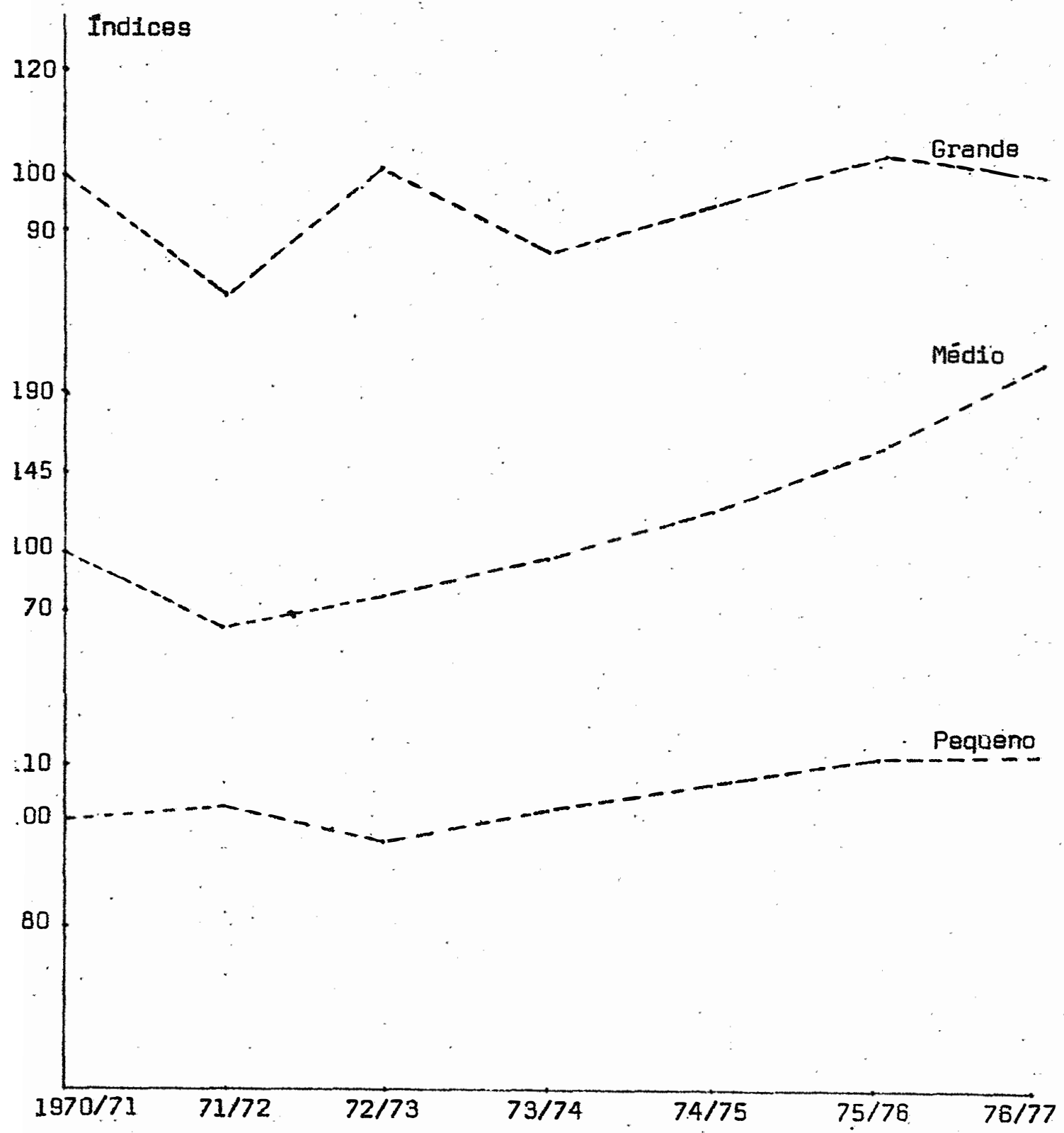

Figura 12 - Indices de crescimento de pecuária de leite $C$. FONTE: Resultados do Modelo. 
Suinocultura tipo banha permaneceu estável no primei ro e terceiro estratos de área, enquanto que no segundo estrato (mé dios produtores) o crescimento no período foi de 1,77 vezes o valor inicial de 1970/71; suinocultura tipo carne apresenta-se apenas nes te último estrato onde obteve crescimento de 2,66 vezes no perfodo. Parece que suinocultura foi atividade com tendência à especialização no modelo utilizado.

Tomando-se $1970 / 71=100$, a área com pastagem art1ficial alcançou, em 1976/77, os fndices 125 e 32, para o segundo e terceiro estratos, respectivamente; no primeiro estrato a área em pasto artificial permaneceu constante. E pastagem natural, apresentou fndices de 147, 124 e 133, para o primeiro, segundo e terceiro estratos de ärea, respectivamente.

As atividades pecuárias têm grande importância na re gião, especialmente a de leite. Porém era preciso cuidado no uso dos seus coeficientes para os quais não se tinha a mesma confiança dispensada aos de culturas anuais, por exemplo, de modo que sua inclusão fez-se com cautela para se evitar especializações ou cargas excessivas. Ao final parece que o comportamento das atividades pecuárias fol acima da expectativa porque bastante coerente, com exceção de suinocultura. Os resultados obedecem de perto ao conhecimento que se possui do problema: o crescimento de pecuária bovina de corte fez-se realmente no estrato grande, enquanto leite $B$ tende para pequenos e médios, e leite $C$ também, com boa distribuição entre eles; talvez a atividade de leite $B$ tenha contado com crescimentos acima 
do real. No entanto houve um crescimento moderado de pecuáría que ë compatível com a tendência na região até esta data.

\section{3 - Produtividade dos Fatores de Produção}

A análise a ser feita comportaria dois procedimentos. Um seria analisar estritamente os resultados do modelo em termos dos recursos que foram realmente utilizados, e outro consistiria em incluir a folga dos recursos disponíveis. A impressão que se tem é que se deve lançar mão de ambos, embora negligenciando às vezes pequenos detalhes. Para dar um exemplo diga-se que mão-de-obra familiar e residente não foram totalmente esgotadas num estrato qualquer, e mais: houve evasão de mão-de-obra familiar devido ao custo de oportunidade a ela dispensado; mas a mão-de-obra residente não usada e sem custo de oportunidade, por suposição implícita, deve permanecer na propriedade. O problema com mão-de-obra deve-se à sua incorporação à princfpio programada para a competição regional, em que um es trato de área podería alugar ou vender os serviços de sua mão-de-obra familiar e residente para outro, e também às imprecisas informa çöes sobre o número de dias trabalhados, que variam tanto que a sub divisão dos períodos para atender a propósitos detalhados deveria ser multo mais partilhada, e nesse caso os dados seriam difíceis de se obter. Situação semelhante ocorre tambēm com terra, serviços de animais de trabalho, de máquinas, etc. 
90.

\subsection{1 - Retorno}

O RETORNO (ver definição na secção 3.2 .5 .3 ), em cruzeiros de 1970 (ver Tabela 4 e Figura 13), é sempre crescente nos três estratos de ärea, e seu crescimento dinâmico é diretamente pro porcional ao tamenho das propriedades. Até o ano de $1974 / 75$, inclusive, os Indices de crescimento comportaram-se normalmente. Nos dois últimos anos do perfodo (1975/76 e 1976/77) se acelera bruscamente - crescimento anterior. Os estratos correspondentes às pequenas, mé dias e grandes propriedades, aumentaram o RETORNO em, respectivamen te, $219 \%, 271 \%$ e $410 \%$ no período. A região inteira teve aumento de aproximadamente $329 \%$ comparando-se $1970 / 71$ com $1976 / 77$.

Tabela 4 - RETORNO, em mil cruzeiros de 1970, por estrato de área e por ano.

\begin{tabular}{|c|c|c|c|}
\hline \multirow{2}{*}{ Anos Agricolas } & \multicolumn{3}{|c|}{ Estratos de Área } \\
\hline & Pequeno & Médio & Grande \\
\hline $1970 / 71$ & $\begin{array}{c}32.876,20 \\
(100)^{a}\end{array}$ & $\begin{array}{c}175.470,00 \\
(100)\end{array}$ & $\begin{array}{c}168.834,00 \\
(100)\end{array}$ \\
\hline $1971 / 72$ & $\begin{array}{c}33.341,35^{b} \\
(101)^{3}\end{array}$ & $\begin{array}{c}198.295,30 \\
(113)\end{array}$ & $\begin{array}{c}198.909,00 \\
(118)\end{array}$ \\
\hline $1972 / 73$ & $\begin{array}{c}44.009,07 \\
(133)\end{array}$ & $\begin{array}{c}262.497,65 \\
(150)\end{array}$ & $\begin{array}{c}279.495,76 \\
(165)\end{array}$ \\
\hline $1973 / 74$ & $\begin{array}{c}50.742,80 \\
(154)\end{array}$ & $\begin{array}{c}320.122,74 \\
(182)\end{array}$ & $\begin{array}{c}321.904,00 \\
(190)\end{array}$ \\
\hline $1974 / 75$ & $\begin{array}{c}52.289,28 \\
(159)\end{array}$ & $\begin{array}{c}360.080,16 \\
(205)\end{array}$ & $\begin{array}{c}436.944,96 \\
(259)\end{array}$ \\
\hline $1975 / 76$ & $\begin{array}{c}77.299,66 \\
(235)\end{array}$ & $\begin{array}{c}528.952,00 \\
(302)\end{array}$ & $\begin{array}{c}673.618,30 \\
(399)\end{array}$ \\
\hline $1976 / 77$ & $\begin{array}{c}104.842,89 \\
(319)\end{array}$ & $\begin{array}{c}651.191,40 \\
(371)\end{array}$ & $\begin{array}{c}860.403,60 \\
(510)\end{array}$ \\
\hline
\end{tabular}

FONTE: Resultados do Modelo.

(a) Os números entre parénteses são indices.

(b) Deflacionados pelo Indice 2 da Fundaçäo Getülio Vargas. 
91.

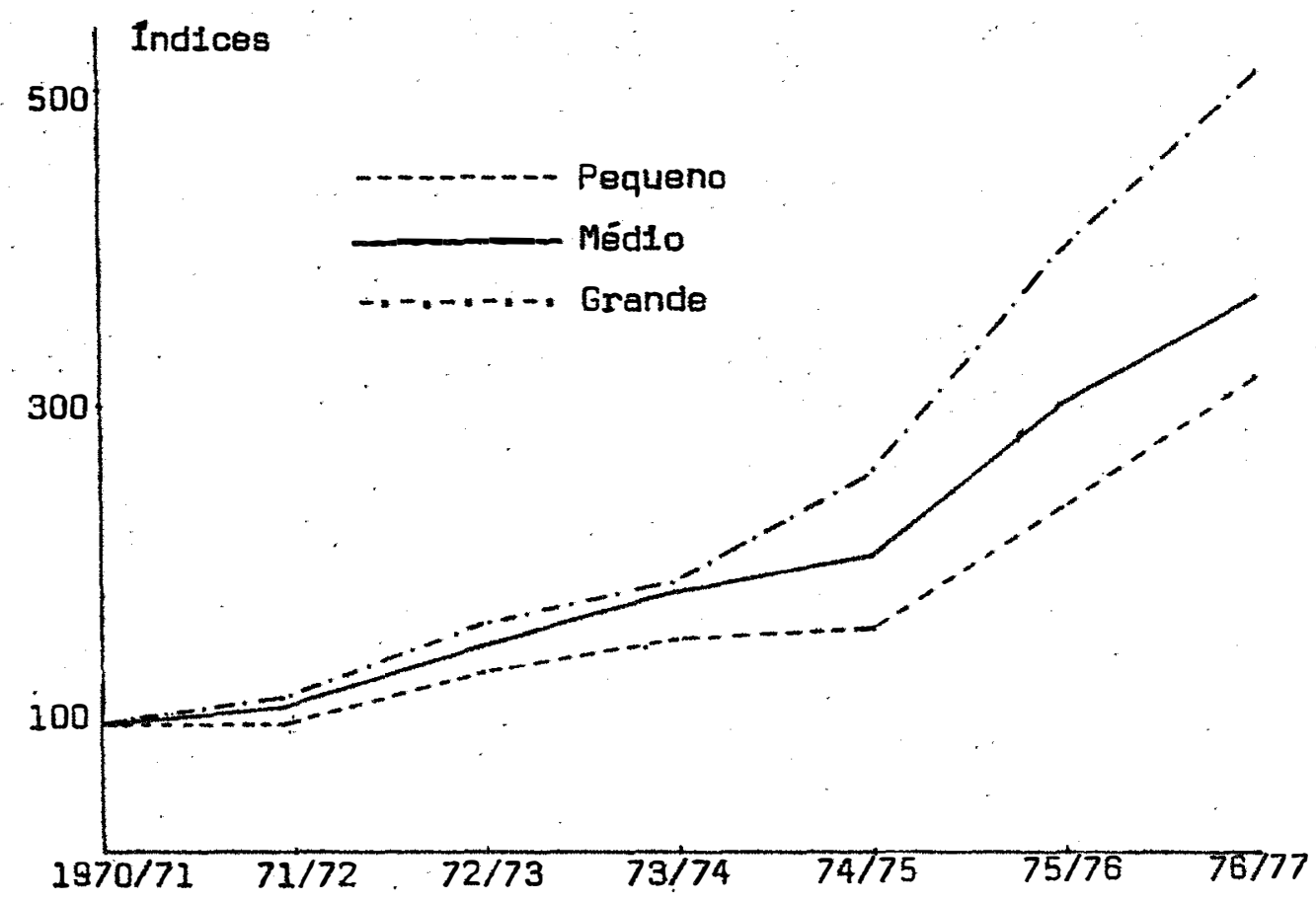

FIgura 13 - Indices de crescimento do RETORND. FONTE: Resultados do Modelo

\subsection{2 - Produtividade da terra}

A produtividade da terra (ver Tabela 5 e Figura 14) e dada pela relação entre a receita Ifquida observada (em Cr\$ de 1970, com valores deflactonados pelo Indice 2 da Revista Conjuntura Econômica, F.G.V.), a a quantidade total de terra ut1lizada (em hec tares): RETORNO/TERRA. Em todos os estratos de ärea a produtividade da terra é crescente durante todo o perfodo considerado lexceção pa ra o ano 1971/72 no primeiro estrato\}, a segue uma lóg 1ca esperada: a produtividade decresce em termos absolutos a partir do estrato pe 
queno em direçāo ao estrato grande. Mas em termos dinâmicos, o que se verifica é exatamente o oposto, ou seja, a tendêncla no período é a de diminuir a diferença entre as produtividades nos estratos, o que significa que o terceiro estrato tem a maior taxa de crescimento da produtividade da terra. Caso se considere a área total disponível (constante no perfodo), o padrão não se modifica indicando no vamente que o valor do RETORNO teve acréscimos mals rápidos nos gru pos de propriedades malores. E evidente que a produtividade, quando se leva em conta a área total, decresce, porque há terras oclosas nos três estratos.

Outro fator que auxilia na explicação da tendência as sinalada é a disponibilidade dos diferentes tipos de terra. Assim,o estrato das grandes propriedades teve possibilidade de crescer rela tivamente mais usando a terra $I$ que é a de melhor qualidade, e portanto de maior rentabilidade, enquanto os demais estratos contaram apenas com o crescimento livre em terra II e III, no que se igualaram às oportunidades do estrato grande. O estrato das pequenas propriedades não pode aumentar a utilização de terra I, e o estrato mé dio o fez parcialmente durante os 3 primeiros anos.

Considerando a região como um todo a produtividade da terra cresceu $251 \%$, de Cr $\$ 283,16 /$ ha, em $1970 / 71$, para Cr $\$ 994,93 /$ ha em 1976/77 (Cr\$ de 1970). Estes resultados estão fortemente influen clados pelos preços de café e soja que atingiram altos nívels nos ültimos anos. 


\subsection{3 - Produtividade do trabalho}

A contratação de mão-de-obra temporária se faz duran te todo o período no estrato superior, enquanto no estrato médio ela toma Impulso depois dos anos iniclais. No estrato pequeno não há con tratação em nenhum momento durante todo o período, ao contrárío, há sempre sobra de mão-de-obra residente e venda dos serviços de mão-de-obra familiar; no estrato médio, as vendas dos serviços do trabalho famillar são bem mals escassas, e a partir dos anos iniclais registra-se o aproveltamento completo da mão-de-obra residente; no estrato superior, tanto uma como outra são sempre aproveitadas. A participação da mão-de-obra familiar é maior quanto menor é o tamanho das propriedades, e o confronto entre os dols estratos extremos nesse sentido mostra uma diferença marcante.

A produtividade do trabalho é dada por RETORNO/TRABA LHO, em que o dividendo é expresso em cruzeiros de 1970 e o divisor emi número total de dias-homens empregados. Neste caso serão desprezados o potencial de trabalho representado pela categoria mão-de-obra residente, eventualmente não utilizada, nem se descontará o nümero de dias-homens da categoria mão-de-obra famillar que façam uso do custo de oportunidade leste último aspecto,quando ocorre, ten de a aumentar a produtividade do trabalho caso se deduza igualmente quantidade e preço respectivos desse fator).

Vê-se pela Tabela 5 e Figura 15 correspondentes, que a produtividade do trabalho é também crescente nos três estratos de ärea. Entretanto, cresce relativamente mais no estrato superior, on 
de alcança 3,86 vezes o valor do ano inicial; segue-se o estrato in ferior com 2,88 vezes, e o estrato médio, com 2,27 vezes.

Em termos absolutos, o período começa com maior produtividade do trabalho no estrato médio, seguindo-lhe o estrato inferior, e depois o superior; a partir de 1973/74, inclusive, as posições dos estratos inferior e médio se invertem até o final do período lesta mudança, em relação ao crescimento dinâmico, opera-se já em 1972/73). Vale ressaltar o crescimento muito grande da produtivi dade do trabalho no estrato inferior (em termos absolutos) nos ülti mos anos, e no estrato superior (em termos dinâmicos) durante todo o período: a posição ocupada pelo estrato médio é nitidamente de su perioridade inicial, que se deteriora ao longo do período.

Na região, a produtividade de trabalho cresce cerca de 3,02 vezes no período.

\section{3 .4 - Produtividade do capital}

A produtividade do capital é dada pela relação RETOR NO/CAIXA. O CAIXA mede a disponibilidade monetäría para fazer frente aos gastos imediatos com compra de insumos, de serviços de traba 1ho, e outros custos. Conforme se observa pela Tabela 5 e Figura 16, no primeiro estrato a produtividade do capital é a maior em todo o período quando se refere ao valor absoluto, com ênfase nos dols ültimos anos; a sequência privilegia o segundo, seguido do terceiro es trato de ärea. o crescimento total obedece quase a mesma ordem, mas Invertendo-se a posição do terceiro e segundo estratos, com $108 \%, 18 \%$ 
e $51 \%$ de aumento nos estratos pequeno, médio e grande, respectivamente, em relação ao ano inicial. O padrão parece-se com a produtividade do trabalho, com o estrato pequeno se distanciando dos demais, enquanto o estrato médio e grande se aproximam, indicando a es tagnação relativa daquele.

Confrontando-se os resultados em termos de evolução da produtividade do capital a partir do ano inicial, o padrão não se define. No primeiro estrato há um decréscimo no ano de 1971/72, seguido por uma estabilização nos três anos seguintes para aumentar nos dois últimos anos. No estrato médio, a produtividade é oscilante e está abaixo do valor inicial nos dois anos seguintes, se estabiliza nos próximos dois anos, e aumenta nos restantes. No terceiro estrato, o padrão é semelhante aos demais, mas a recuperação ascendente se dá no ano de 1974/75. Uma explicação parcial para a posição do estrato intermediário é que o crescimento do CAIXA neste caso ultrapassa a velocidade com que cresce o mesmo nos demais estratos, quando comparado com o crescimento dos RETORNOS respectivos.

Para a região, a produtividade do capital é de 2,20 em 1970/71, e de 2,98 em 1976/77, correspondendo a um crescimento de cerca de 1,35 vezes, no perfodo.

Considerando-se todos os dados de produtividade para a região, verifica-se que a maior contribuição adveio da produtividade da terra, que aumentou 3,51 vezes no período, seguindo-se a pro dutividade do trabalho com 3,02 vezes, e por fim a produtividade do 
capital de giro, em torno de 1,35 vezes. De todos os estratos, é nI tido e um pouco paradoxal que o estrato julgado a priori como o mais eficiente - o estrato médio - teve um comportamento até aqui que o coloca como o mais lento em ganhos de produtividade, à exceção da produtividade da terra. O estrato grande, por sua vez, experimentou visivel melhoria, e liderou todos os aumentos relativos nos indices de produtividade. E o estrato pequeno pode-se dizer que manteve sua posição durante o perf́odo, mantendo-se como intermediärio no ganho relativo de produtividade. 
Tabela 5 - Produtividade da terra, em cruzeiros de 1970 por hectare de terra utilizada, por estrato de ärea e por ano.Pro dutividade do trabalho, en cruzeiros de 1970 por dias-hó mens empregados, por estrato de área e por ano. Produti= vidade do capital, por estrato de área a por ano.

\begin{tabular}{|c|c|c|c|c|c|c|c|c|c|}
\hline \multirow{2}{*}{ ANOS } & \multicolumn{3}{|c|}{$\begin{array}{c}\text { PRODUTIVIDADE DA } \\
\text { TERRA }\end{array}$} & \multicolumn{3}{|c|}{$\begin{array}{c}\text { PRODUTIVIDADE DO } \\
\text { TRABALHO }\end{array}$} & \multicolumn{3}{|c|}{$\begin{array}{l}\text { PRODUTIVIDADE DO } \\
\text { CAPITAL }\end{array}$} \\
\hline & $\begin{array}{l}\text { Estre } \\
\text { Pequeno }\end{array}$ & $\begin{array}{l}\text { atos de } \\
\text { Médio. }\end{array}$ & $\begin{array}{l}\text { Area } \\
\text { Erande }\end{array}$ & $\begin{array}{l}\text { Estra } \\
\text { Pequeno }\end{array}$ & $\begin{array}{l}\text { tos de } \\
\text { Méd1o }\end{array}$ & $\begin{array}{l}\text { Area } \\
\text { Grande }\end{array}$ & $\begin{array}{r}\text { Estra } \\
\text { Pequeno }\end{array}$ & $\begin{array}{l}\text { os de } \\
\text { Médio. }\end{array}$ & $\begin{array}{l}\text { Area } \\
\text { Grande }\end{array}$ \\
\hline $1970 / 71$ & $\begin{array}{l}753,07 \\
(100)^{\mathrm{a}}\end{array}$ & $\begin{array}{r}391,00 \\
(100)\end{array}$ & $\begin{array}{r}201,08 \\
(100)\end{array}$ & $\begin{array}{l}16,59 \\
(100)\end{array}$ & $\begin{array}{l}16,94 \\
(100)\end{array}$ & $\begin{array}{r}9,93 \\
(100)\end{array}$ & $\begin{array}{r}2,98 \\
(100)\end{array}$ & $\begin{array}{r}2,92 \\
(100)\end{array}$ & $\begin{array}{r}1,69 \\
(100)\end{array}$ \\
\hline $1971 / 72$ & $\begin{array}{r}735,83 \\
(98)\end{array}$ & $\begin{array}{r}442,66 \\
(113)\end{array}$ & $\begin{array}{r}243,38 \\
(121)\end{array}$ & $\begin{array}{l}17,16 \\
(103)\end{array}$ & $\begin{array}{l}18,78 \\
(111)\end{array}$ & $\begin{array}{l}11,91 \\
(120)\end{array}$ & $\begin{array}{l}2,81 \\
(94)\end{array}$ & $\begin{array}{l}2,51 \\
(86)\end{array}$ & $\begin{array}{l}1,59 \\
(94)\end{array}$ \\
\hline $1972 / 73$ & $\begin{array}{r}888,21 \\
(118)\end{array}$ & $\begin{array}{r}558,85 \\
(143)\end{array}$ & $\begin{array}{r}355,29 \\
(117)\end{array}$ & $\begin{array}{l}22,95 \\
(138)\end{array}$ & $\begin{array}{l}21,94 \\
(129)\end{array}$ & $\begin{array}{l}15,15 \\
(153)\end{array}$ & $\begin{array}{r}3,38 \\
(113)\end{array}$ & $\begin{array}{l}2,65 \\
(91)\end{array}$ & $\begin{array}{r}1.79 \\
(106)\end{array}$ \\
\hline $1973 / 74$ & $\begin{array}{r}956,16 \\
(127)\end{array}$ & $\begin{array}{r}653,31 \\
(167)\end{array}$ & $\begin{array}{r}411,87 \\
(205)\end{array}$ & $\begin{array}{l}26,86 \\
(162)\end{array}$ & $\begin{array}{l}24,32 \\
(144)\end{array}$ & $\begin{array}{l}17,44 \\
(176)\end{array}$ & $\begin{array}{r}3,36 \\
(113)\end{array}$ & $\begin{array}{l}2,46 \\
(84)\end{array}$ & $\begin{array}{l}1,68 \\
(99)\end{array}$ \\
\hline $1974 / 75$ & $\begin{array}{r}1010,01 \\
(134)\end{array}$ & $\begin{array}{r}683,13 \\
(175)\end{array}$ & $\begin{array}{r}539,96 \\
(259)\end{array}$ & $\begin{array}{l}28,28 \\
(170)\end{array}$ & $\begin{array}{l}26,09 \\
(154)\end{array}$ & $\begin{array}{l}21,75 \\
(219)\end{array}$ & $\begin{array}{r}3,36 \\
(113)\end{array}$ & $\begin{array}{l}2,47 \\
(84)\end{array}$ & $\begin{array}{l}1,99 \\
(118)\end{array}$ \\
\hline $1975 / 76$ & $\begin{array}{r}1331,42 \\
(177)\end{array}$ & $\begin{array}{r}933,48 \\
(239)\end{array}$ & $\begin{array}{r}744,44 \\
(370)\end{array}$ & $\begin{array}{l}37,66 \\
(227)\end{array}$ & $\begin{array}{l}34,86 \\
(206)\end{array}$ & $\begin{array}{l}31,27 \\
(315)\end{array}$ & $\begin{array}{r}4,91 \\
(165)\end{array}$ & $\begin{array}{r}3,26 \\
(112)\end{array}$ & $\begin{array}{r}2,54 \\
(150)\end{array}$ \\
\hline 197 & $\begin{array}{c}1716,231 \\
(228)\end{array}$ & $\begin{array}{r}1058,57 \\
(271)\end{array}$ & $\begin{array}{r}907,19 \\
(451)\end{array}$ & $\begin{array}{l}47,77 \\
(288)\end{array}$ & $\begin{array}{l}38,50 \\
(227)\end{array}$ & $\begin{array}{l}38,31 \\
(386)\end{array}$ & $\begin{array}{r}6,19 \\
(208)\end{array}$ & $\begin{array}{r}3,45 \\
(118)\end{array}$ & $\begin{array}{r}2,56 \\
(151)\end{array}$ \\
\hline
\end{tabular}

FONTE: Resultados do Modrlo.

(a) Os números entre parênteses são Indices.

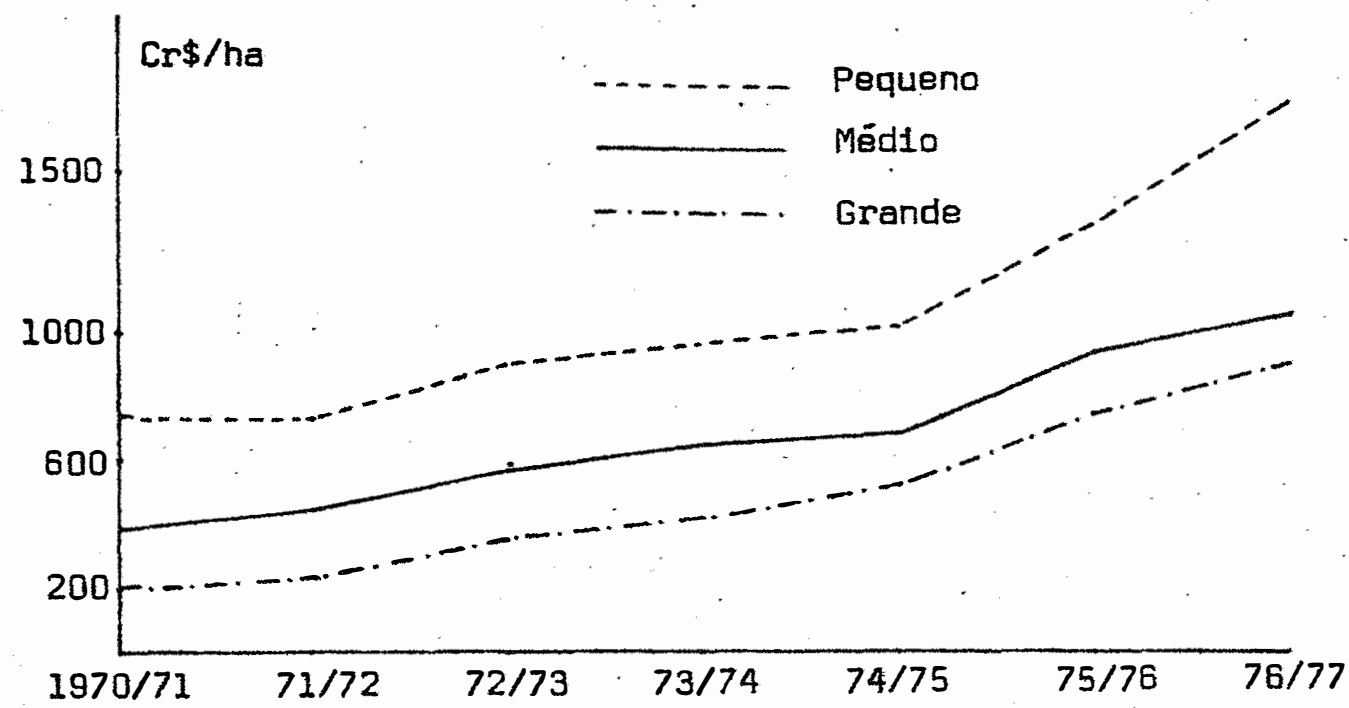

Figura 14 - Produtividade da terra. FONTE: Resultados do Modelo: 


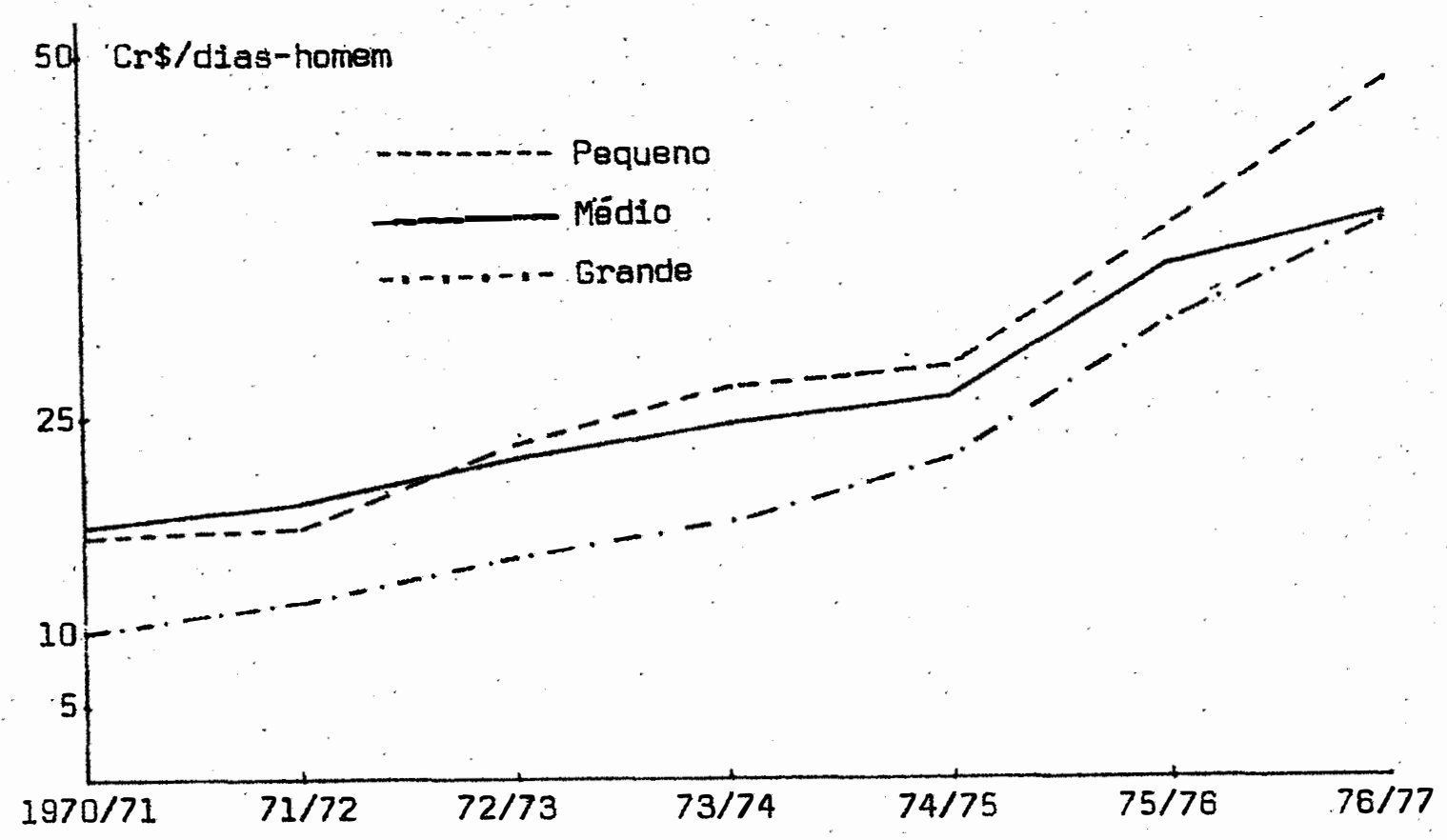

Figura 15 - Produtividade do trabalho. FONTE: Resultados do Modelo.

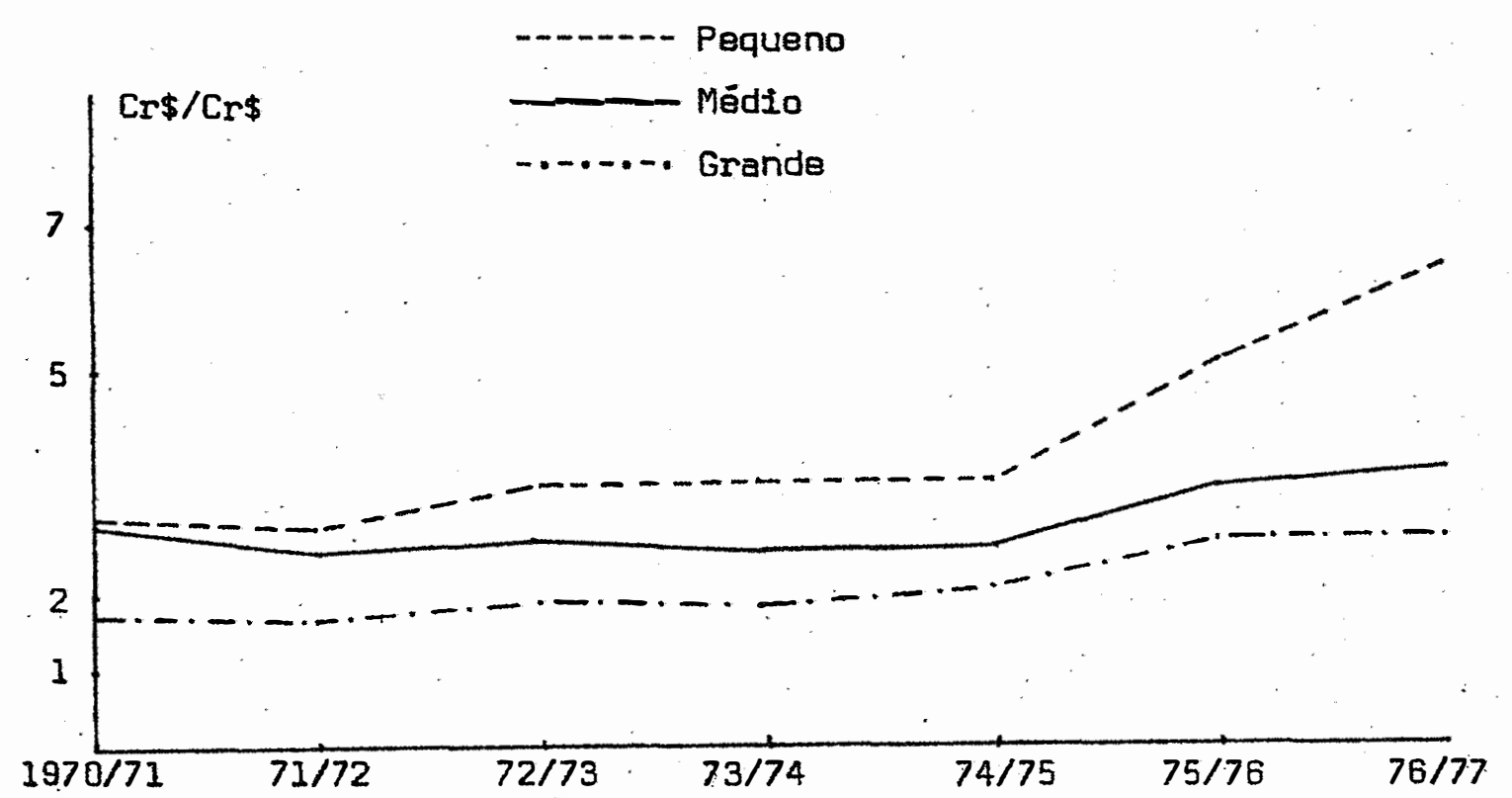

Figura 16. - Produtividade do capital

FONTE: Resultados do Modelo. 


\section{4 - Proporcionalidade Entre os Fatores de Produção}

A proporcionalidade entre os fatores de produção deve mostrar qual a tendência observada nos três estratos de área, pois é basicamente o aspecto que distingue os comportamentos respec tivos. A análise será feita a partir dos recursos efetivamente usados, não se considerando a folga existente, senão para registrar al gum fato relevante; neste sentido, ainda são válidas as observações feitas anteriormente a esse propósito.

\subsection{1 - Trabalho e terra}

A evolução da relação TRABALHO/TERRA é apresentada na Tabela 6 e Flgura 17 correspondentes. A nümero de dias-homens empre gados por hectare de terra utilizada é maior nas propriedades peque nas (mesmo desprezando-se a mão-de-obra residente não empregada e a venda dos serviços da mão-de-obra familiarl, seguindo-se as proprie dades médias, e as grandes propriedades. Durante o período não se observa grandes alteraçōes, mas percebe-se que os estratos pequeno e médio tendem a se aproximar, ao passó que este ültimo se distancia do estrato grande.

A menor taxa de crescimento na relação TRABALHO/TERRA, no período, pertence ao estrata pequeno que praticamente se man tém estabilizada até o final; passa de 27,38 dias-homens $(d-H)$ por hectare, em 1970/71, para 29,38 d-H/ha, em 1976/77. No estrato médio, a taxa de crescimento daquela relação é quase sempre crescente, 
mas de modo lento, passando de 23,07 d-H/ha, em 1970/71, a 27,49 d-H/ha, em 1976/77, sendo que é a malor taxa de crescimento dos três estratos. No estrato grande a taxa de crescimento se estabiliza a partir do ano de $1972 / 73$, e muda de $20,25 \mathrm{~d}-\mathrm{H} / \mathrm{ha}$, no início do período, para $23,68 \mathrm{~d}-\mathrm{H} / \mathrm{ha}$, ao final.

Tabela 6 - Relação TRABALHO/TERRA, em dias-homens empregados por hec tare de terra utilizada, por estrato de área e por ano.

\begin{tabular}{|c|c|c|c|c|c|c|c|c|c|}
\hline \multirow{2}{*}{ ANOS } & \multicolumn{3}{|c|}{$\begin{array}{c}\text { TRABALHO/TERRA }{ }^{\mathrm{a}} \\
\text { I }\end{array}$} & \multicolumn{3}{|c|}{$\begin{array}{c}\text { TRABALHO/TERRA } \\
\text { II }\end{array}$} & \multicolumn{3}{|c|}{$\begin{array}{c}\text { TRABALHO/TERRA } \\
\text { III }\end{array}$} \\
\hline & $\begin{array}{l}\text { Estrat } \\
\text { Pequeno }\end{array}$ & $\begin{array}{l}\text { tos de } \\
\text { Médio }\end{array}$ & $\begin{array}{l}\text { ärea } \\
\text { Grande }\end{array}$ & $\begin{array}{r}\text { Estra } \\
\text { Pequeno }\end{array}$ & $\begin{array}{l}\text { tos de } \\
\text { Médio }\end{array}$ & $\begin{array}{l}\text { ärea } \\
\text { Grande }\end{array}$ & $\begin{array}{r}\text { Estra } \\
\text { Pequeno }\end{array}$ & $\begin{array}{l}\text { tos de } \\
\text { Médio }\end{array}$ & $\begin{array}{l}\text { ärea } \\
\text { Grande }\end{array}$ \\
\hline $1970 / 71$ & $\begin{array}{l}48,73 \\
(100)^{d}\end{array}$ & $\begin{array}{l}33,03 \\
(100)\end{array}$ & $\begin{array}{l}20,25 \\
(100)\end{array}$ & $\begin{array}{l}45,38 \\
(100)\end{array}$ & $\begin{array}{l}23,07 \\
(100)\end{array}$ & $\begin{array}{l}20,25 \\
(100)\end{array}$ & $\begin{array}{l}27,38 \\
(100)\end{array}$ & $\begin{array}{l}23,07 \\
(100)\end{array}$ & \\
\hline $1971 / 72$ & $\begin{array}{r}48,28 \\
(99)\end{array}$ & $\begin{array}{r}26,96 \\
(82)\end{array}$ & $\begin{array}{l}20,43 \\
(101)\end{array}$ & $\begin{array}{r}42,88 \\
(94)\end{array}$ & $\begin{array}{l}23,56 \\
(102)\end{array}$ & $\begin{array}{l}20,43 \\
(101)\end{array}$ & $\begin{array}{l}28,09 \\
(102)\end{array}$ & $\begin{array}{r}22,07 \\
(96)\end{array}$ & $\begin{array}{l}20,43 \\
(101)\end{array}$ \\
\hline 1972 & $\begin{array}{r}45,96 \\
(94)\end{array}$ & $\begin{array}{r}25,47 \\
(77)\end{array}$ & $\begin{array}{l}23,45 \\
(116)\end{array}$ & $\begin{array}{r}38,70 \\
(85)\end{array}$ & $\begin{array}{l}25,47 \\
(110)\end{array}$ & $\begin{array}{l}23,45 \\
(116)\end{array}$ & $\begin{array}{l}27,75 \\
(101)\end{array}$ & $\begin{array}{l}23,81 \\
(103)\end{array}$ & $\begin{array}{l}23,45 \\
(116)\end{array}$ \\
\hline $1973 / 74$ & $\begin{array}{r}44,60 \\
(91)\end{array}$ & $\begin{array}{r}26,87 \\
(81)\end{array}$ & $\begin{array}{l}23,61 \\
(117)\end{array}$ & $\begin{array}{r}35,60 \\
(78)\end{array}$ & $\begin{array}{l}26,87 \\
(116)\end{array}$ & $\begin{array}{l}23,61 \\
(117)\end{array}$ & $\begin{array}{l}27,84 \\
(102)\end{array}$ & $\begin{array}{l}25,58 \\
(111)\end{array}$ & $\begin{array}{l}23,61 \\
(117)\end{array}$ \\
\hline $1974 / 75$ & $\begin{array}{r}45,88 \\
(94)\end{array}$ & $\begin{array}{r}26,18 \\
(79)\end{array}$ & $\begin{array}{l}23,90 \\
(118)\end{array}$ & $\begin{array}{r}35,72 \\
(79)\end{array}$ & $\begin{array}{l}26,18 \\
(113)\end{array}$ & $\begin{array}{l}23,90 \\
(118)\end{array}$ & $\begin{array}{l}29,08 \\
(106)\end{array}$ & $\begin{array}{l}25,49 \\
(110)\end{array}$ & $\begin{array}{l}23,90 \\
(118)\end{array}$ \\
\hline $1975 / 76$ & $\begin{array}{r}39,35 \\
(81)\end{array}$ & $\begin{array}{r}26.77 \\
(81)\end{array}$ & $\begin{array}{l}23,80 \\
(117)\end{array}$ & $\begin{array}{r}35,35 \\
(78)\end{array}$ & $\begin{array}{l}26,77 \\
(116)\end{array}$ & $\begin{array}{l}23,80 \\
(117)\end{array}$ & $\begin{array}{l}29,16 \\
(106)\end{array}$ & $\begin{array}{l}26,77 \\
(116)\end{array}$ & $\begin{array}{l}23,80 \\
(117)\end{array}$ \\
\hline $1976 / 77$ & $\begin{array}{r}35,91 \\
(74)\end{array}$ & $\begin{array}{r}27,49 \\
(83)\end{array}$ & $\begin{array}{l}23,68 \\
(117)\end{array}$ & $\begin{array}{r}35,92 \\
(79)\end{array}$ & $\begin{array}{l}27,49 \\
(119)\end{array}$ & $\begin{array}{l}23,68 \\
(117)\end{array}$ & $\begin{array}{l}29,38 \\
(107)\end{array}$ & $\begin{array}{l}27,49 \\
(119)\end{array}$ & $\begin{array}{l}23,68 \\
(117)\end{array}$ \\
\hline
\end{tabular}

FONTE: Resultados do Modelo.

(a) A relação I inclui todo o trabalho.

(b) A relação II exclui de I a categoria mão-de-obra residente näo utilizada.

(c) A relação III exclui de II os serviços da categoría mão-de-obra familiar vendidos fora da propriedade.

(d) Os nümeros entre parênteses são índices. 


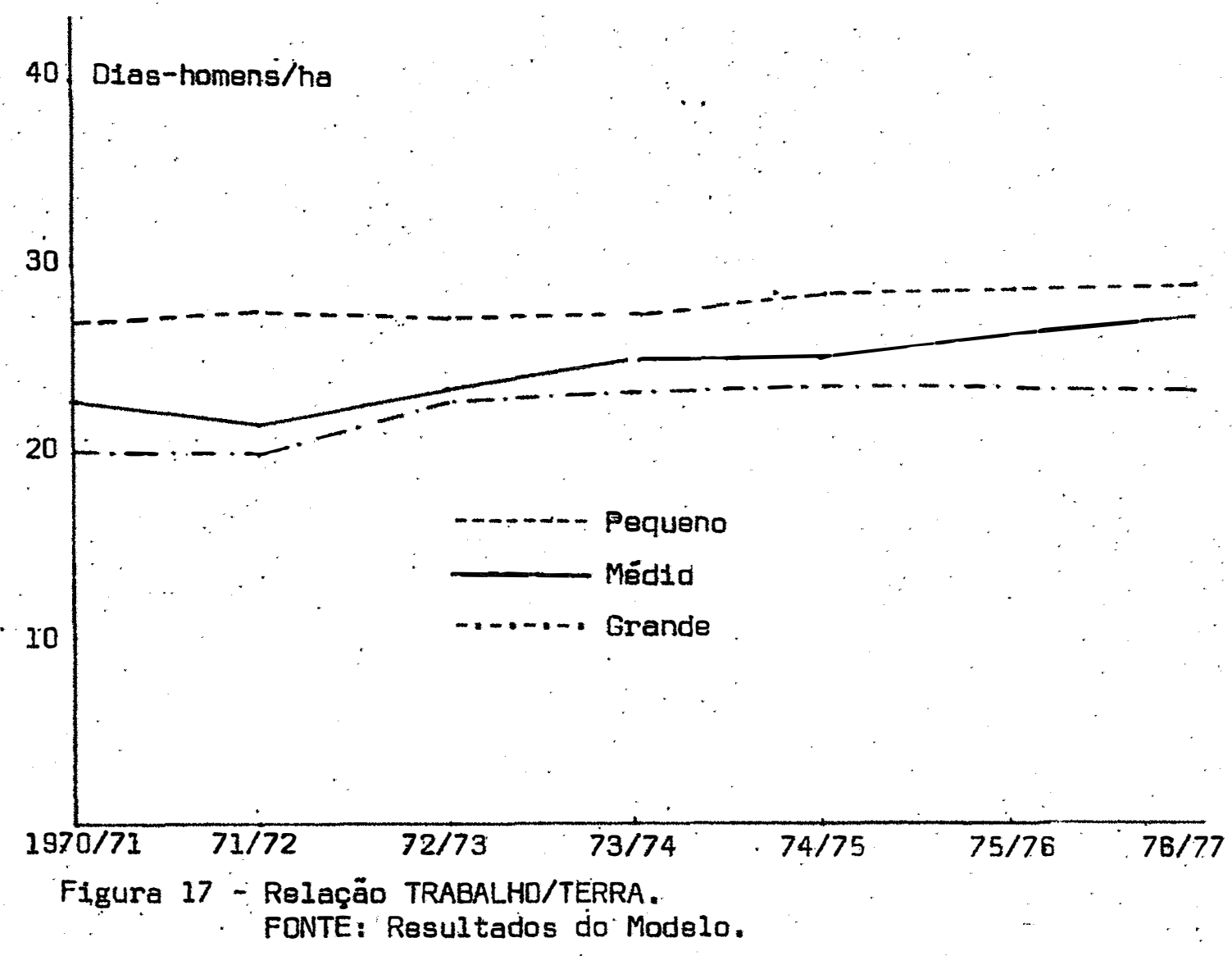

As diferenças são poucas, tanto entre os estratos co mo entre os anos, durante o perfodo, sugerindo que o comportamento nos estratos praticamente não se modifica em termos da taxa de subs titulçäo entre os fatores terra e trabalho. Mas existem alguns problemas que podem ser visualizados na medida em que se tenta ampliar a anälise, da maneira como se segue. 
A produtividade do trabalho pode ser dividida em dois componentes: RETORNO/TRABALHO $=($ RETORNO/TERRA $) .($ TERRA/TRABALHO $)$. O prime1ro componente mede aproximadamente um tipo de tecnologia de nominada blológica (poupadora de terra), enquanto o segundo componente estima o grau de tecnologia mecânica (poupadora de trabalho). No presente modelo, as opções permitidas para o componente RETORNO/TERRA foram bastante limitadas,principalmente pela ausêncla de alternativas tecnológicas, traduzida por (a) no máximo duas tecnologias para algumas das atividades produtivas, e (b) pelo fato de que as tecnologlas diferencladas o eram com ènfase no uso de maquinarla. Isto fez com que a produtividade da terra, paradoxal mente, se devesse a outras causas, e não em funçäo de ganhos rea1s em produtividade. Explica-se: o aumento na produtividade da terra se deve a que o RETORNO cresceu mals rapldamente que a ocupação de novas áreas, e ocorreu desse modo porque, em primeiro lugar, o fndi ce de preços dos produtos agrícolas cresceu mals que o Indice geral de preços usado na deflação para cruzelros de 1970 e, em segundo lu gar, pela eficiêncla com que o modelo escolhe as atividades que pos suam receltas liquidas malores: e resta alnda outras contribulções que a estrutura do modelo ofereceu, na forma de subsidios e superes timativas do fluxo monetárto do capital de giro, como se verá adian te.

o uso extensivo da terra, em todos os estratos de área, dado pela relativa facilidade com que se teve acesso a novas áreas, com exceção de terra tipo I (culturas anua1s), é também umfa 
to que ajuda a compreender os resultados do modelo. Para corroborá-10, basta notar a relação FERTILIZANTES/TERRA, que seguramente é um Indice cujo crescimento mostra tecnologia biológica poupadora de terra. Acompanhando-se pela Tabela 7 e Figura 18 correspondentes, $0 \underline{-}$ serva-se que o crescimento nesta relação ocorre apenas nos estratos superiores londe não houve limites tão restritivos para uso da terra I), ao passo que no estrato inferior (com limites atingidos desde o inf́cio para esta categorial a quantidade de fertilizantes, em kg/ha, cal ao longo de todo o perfodo. Curiosamente, o uso de adubos aumentava no estrato médio, quando a partir de $1974 / 75$, este co meça a cair, embora lentamente. Isto se explica quando se observa que o limite para terra tipo I (a que mais usa adubação) fora atingido um ano antes, e após um perfodo de ajustamento em que a quanti dade por hectare permanece constante, ocorre decréscimos nos anos se guintes.

A relação INSUMOS MODERNOS/TERRA (ver Tabela 7 e Figura 19) também enfatiza o mesmo ponto de vista (insumos modernos é representado basicamente por sementes, defensivos, rações e medicamentos). Em termos absolutos a relação entre cruzeiros de 1970 gastos com insumos modernos e hectares de terra utilizada é francamente maior no estrato inferior, no inf́cio do período, seguida do estrato médio e do superior; ao longo do tempo, no entanto, ela se de. teriora para o primeiro enquanto cresce para os dois últimos,já com o estrato médio alcançando o maior valor ao fim do perfodo, a com a maior porcentagem de aumento em relação a 1970/71. 
Tabela 7 - Relaçäo FERTILIZANTES/TERRA, em quilogramas por hectare de terra ut1lizada, por estrato de área e por ano. Relação INSUMOS MODERNOS/TERRA, em cruzeiros de 1970 por hec tare de terra utilizada, por estrato de ărea e por ano.

\begin{tabular}{|c|c|c|c|c|c|c|c|}
\hline \multirow{2}{*}{ ANOS } & & \multicolumn{3}{|c|}{ FERTLIZANTES/TERRA } & \multicolumn{3}{|c|}{ INSUMOS MODERNOS/TERRA } \\
\hline & & $\begin{array}{l}\text { Estra } \\
\text { Pequeno }\end{array}$ & $\begin{array}{l}\text { tos de } \\
\text { Médio }\end{array}$ & $\begin{array}{l}\text { área } \\
\text { Grande }\end{array}$ & $\begin{array}{l}\text { Estro } \\
\text { Pequeno }\end{array}$ & $\begin{array}{l}\text { tos de } \\
\text { Médio }\end{array}$ & $\begin{array}{l}\text { ärea } \\
\text { Grande }\end{array}$ \\
\hline $1970 / 71$ & & $\begin{array}{r}126,17 \\
(100)^{a}\end{array}$ & $\begin{array}{l}73,03 \\
(100)\end{array}$ & $\begin{array}{l}46,78 \\
(100)\end{array}$ & $\begin{array}{r}182,69 \\
(100)\end{array}$ & $\begin{array}{r}105,60 \\
(100)\end{array}$ & $\begin{array}{l}87,09 \\
(100)\end{array}$ \\
\hline $1971 / 72$ & & $\begin{array}{r}120,92 \\
(96)\end{array}$ & $\begin{array}{l}73,62 \\
(101)\end{array}$ & $\begin{array}{l}52,10 \\
(111)\end{array}$ & $\begin{array}{r}175,25 \\
(96)\end{array}$ & $\begin{array}{r}102,95 \\
(97)\end{array}$ & $\begin{array}{r}86,41 \\
(99)\end{array}$ \\
\hline $1972 / 73$ & & $\begin{array}{r}113,53 \\
(90)\end{array}$ & $\begin{array}{l}77,86 \\
(107)\end{array}$ & $\begin{array}{l}57,33 \\
(122)\end{array}$ & $\begin{array}{r}172,80 \\
(95)\end{array}$ & $\begin{array}{r}105,95 \\
(100)\end{array}$ & $\begin{array}{r}100,05 \\
(115\}\end{array}$ \\
\hline $1973 / 74$ & & $\begin{array}{r}112,58 \\
\text { (89) }\end{array}$ & $\begin{array}{l}82,33 \\
(113)\end{array}$ & $\begin{array}{l}61,04 \\
(130)\end{array}$ & $\begin{array}{r}186,45 \\
(102)\end{array}$ & $\begin{array}{r}134,70 \\
(128)\end{array}$ & $\begin{array}{r}118,67 \\
(136)\end{array}$ \\
\hline $1974 / 75$ & $"$ & $\begin{array}{r}112,52 \\
(89)\end{array}$ & $\begin{array}{l}82,66 \\
(113)\end{array}$ & $\begin{array}{l}63,04 \\
(135)\end{array}$ & $\begin{array}{r}230,70 \\
(126)\end{array}$ & $\begin{array}{r}166,40 \\
(158)\end{array}$ & $\begin{array}{r}135,37 \\
(155)\end{array}$ \\
\hline $1975 / 76$ & & $\begin{array}{r}112,47 \\
(89)\end{array}$ & $\begin{array}{l}80,97 \\
(111)\end{array}$ & $\begin{array}{l}61,72 \\
(132)\end{array}$ & $\begin{array}{r}205,71 \\
(107)\end{array}$ & $\begin{array}{r}150,57 \\
(143)\end{array}$ & $\begin{array}{r}122,46 \\
(141)\end{array}$ \\
\hline $1976 / 77$ & & $\begin{array}{r}112,25 \\
(89)\end{array}$ & $\begin{array}{l}77,80 \\
(106)\end{array}$ & $\begin{array}{l}62,90 \\
(134)\end{array}$ & $\begin{array}{r}163,75 \\
(90)\end{array}$ & $\begin{array}{r}166,88 \\
(158)\end{array}$ & $\begin{array}{r}123,79 \\
(142)\end{array}$ \\
\hline
\end{tabular}

FONTE: Resultados do Modelo.

(a) Os nümeros entre parênteses são Indices.

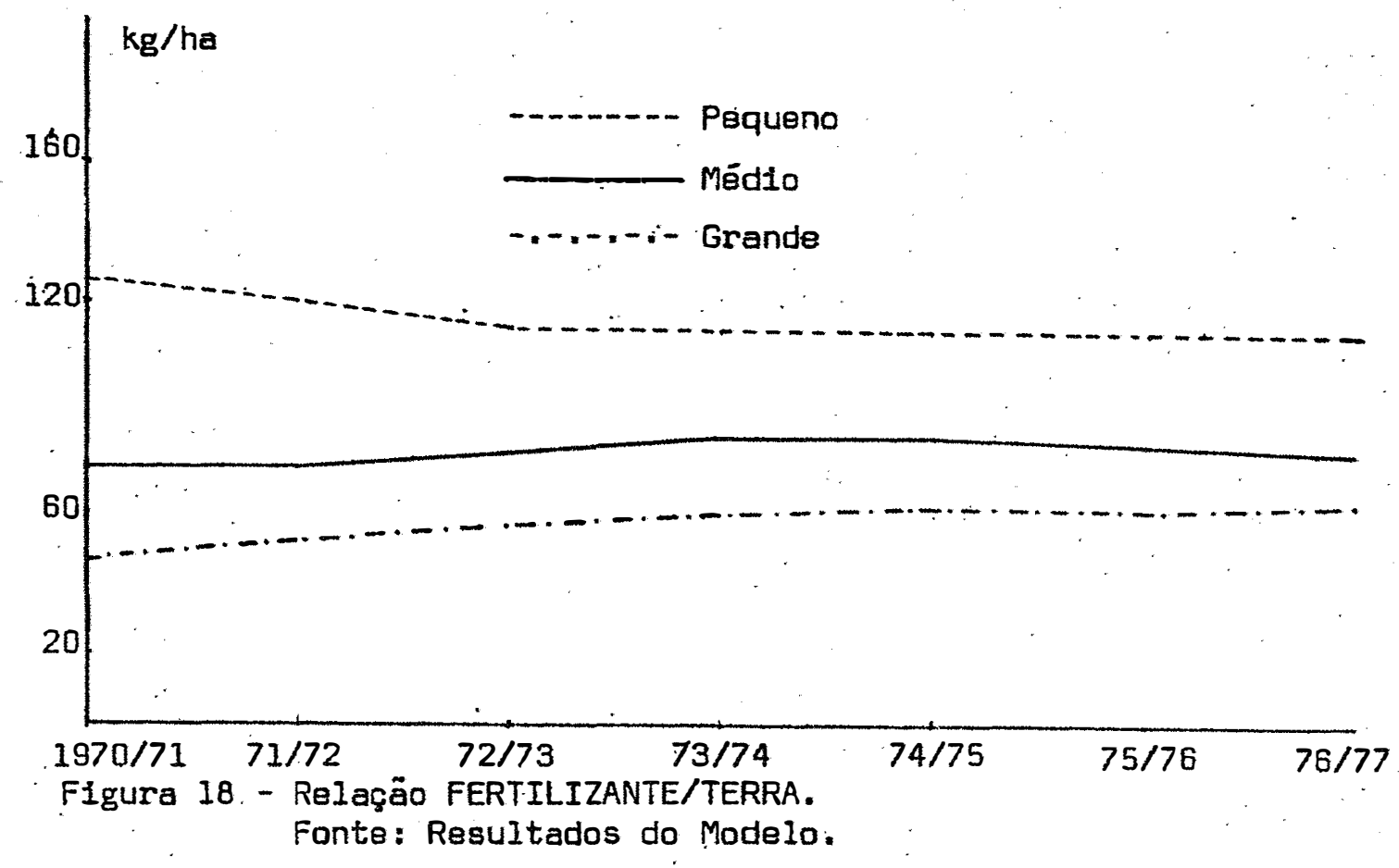




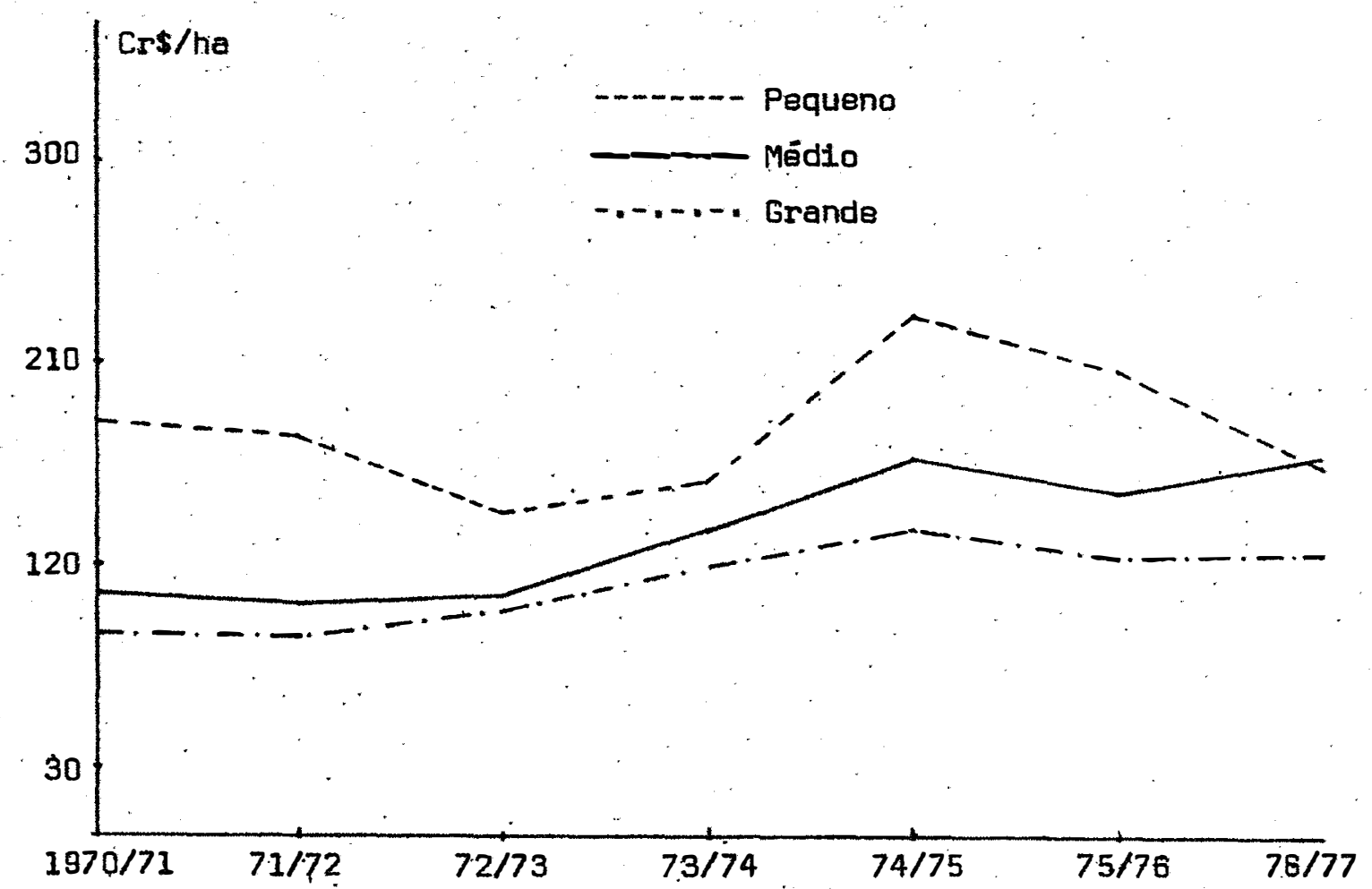

FIgura 19 - Relação INSUMOS MODERNOS/TERRA. FONTE: Resultados do Modelo.

O Item Insumos modernos é usado nos três tipos de ter ra, o que permite Inferênclas comperävels entre os estratos. Tem-se a registrar que o estrato médio possul atividades, como suinocultura tipo carne, que não esteve disponível para os demals estratos, sendo atividade que cresceu no perfodo, e que se utiliza de insumos modernos na forma de rações; outras atividades, como tomate e soja, contemplam apenas os dols estratos superı́ores de área.

o outro componente dado por TERRA/TRABALHO é o inver so do que se tem na Tabela 4 , e fol o ponto de partida para a dis- 
cussão. Pode-se especular, com base nas poucas e frágeis indicações, que o estrato inferior, ao conträrio de todas as expectativas, cres ce "poupando" mais trabalho que terra, quando comparado com os demais, que fazem o inverso em relação àquele, e de modo mais intensi vo o estrato intermediário. Ao se considerar estes resultados como parcialmente váliḍos, verifica-se que os estratos extremos tendem a adotar um caminho de crescimento que inverte as possibilidades de incorporação dos seus recursos relativamente mais abundantes: terra, nos estratos superiores, e trabalho no estrato inferior. A comprova ção ou negação dessa hipótese se efetivaria, caso se conseguisse am pliar as opçöes tecnológicas no presente modelo, acompanhadas de uma divisão de terras pormenorizada, e procedendo à competição regional com novo tratamento para as diversas categorias de mão-de-obra. Vol tar-se-á ao tema se se comprovar que outros indicadores apontam no sentido sugerido.

A análise da proporcionalidade entre os fatores de produção coloca outro problema. Trata-se do horizonte de planejamen to em consideração: quanto mais extenso for o perfodo maior será a visibilidade quanto à formação de tendências no processo do desenvol vimento regional; portanto, é de se esperar que num perfodo de sete anos não haja mudanças quantitativas ou qualitativas drásticas. 


\subsection{2 - Trabalho e Trator}

A relação TRABALHO/TRATOR mantem-se em todo o perfodo numa escala cujo valor cresce do estrato inferior ao superior, a Indicar que naquele precisa-se de menor quantidade de trabalho para cada unidade de máquina empregada. A taxa de substituição de trabatho por mäquina ao longo do perfodo é maior no estrato superior, ao passo que é quase estacionária no estrato médio, e menor no estrato Inferior, onde é mals correto afirmar que a substituição se faz de máquina por trabalho. Os dados podem ser vistos em detalhes na Tabe la 8 e Figura 20 .

Tabela 8 - Relação TRABALHO/TRATOR, em dias-homens empregados por dias-máquina utilizados, por estrato de área e por ano.

\begin{tabular}{|c|c|c|c|}
\hline \multirow{2}{*}{ ANOS } & \multicolumn{3}{|c|}{ Estratos de área } \\
\hline & Pequeno & Médio & Grande \\
\hline 1970/71 & $\begin{array}{l}17,63 \\
(100)^{a}\end{array}$ & $\begin{array}{l}22,74 \\
(100)\end{array}$ & $\begin{array}{l}27,62 \\
(100)\end{array}$ \\
\hline $1971 / 72$ & $\begin{array}{l}37,61 \\
(100)\end{array}$ & $\begin{array}{r}18,50 \\
(81)\end{array}$ & $\begin{array}{r}24,33 \\
(88)\end{array}$ \\
\hline $1972 / 73$ & $\begin{array}{r}16,85 \\
{[96]}\end{array}$ & $\begin{array}{r}20,34 \\
(89)\end{array}$ & $\begin{array}{r}26,86 \\
(97)\end{array}$ \\
\hline $1973 / 74$ & $\begin{array}{l}17,66 \\
(100)\end{array}$ & $\begin{array}{r}20,65 \\
\text { (91) }\end{array}$ & $\begin{array}{r}25,69 \\
(93)\end{array}$ \\
\hline $1974 / 75$ & $\begin{array}{l}18,39 \\
(104)\end{array}$ & $\begin{array}{r}20,32 \\
(89)\end{array}$ & $\begin{array}{r}26,03 \\
(94)\end{array}$ \\
\hline $1975 / 76$ & $\begin{array}{l}20,03 \\
\text { (114) }\end{array}$ & $\begin{array}{r}20,98 \\
(92)\end{array}$ & $\begin{array}{r}26,78 \\
(97)\end{array}$ \\
\hline $1976 / 77$ & $\begin{array}{l}19,45 \\
(110)\end{array}$ & $\begin{array}{r}22,60 \\
(99)\end{array}$ & $\begin{array}{r}26,53 \\
(96)\end{array}$ \\
\hline
\end{tabular}

FONTE: Resultados do Modelo.

(a) Os números entre parênteses são Indices. 


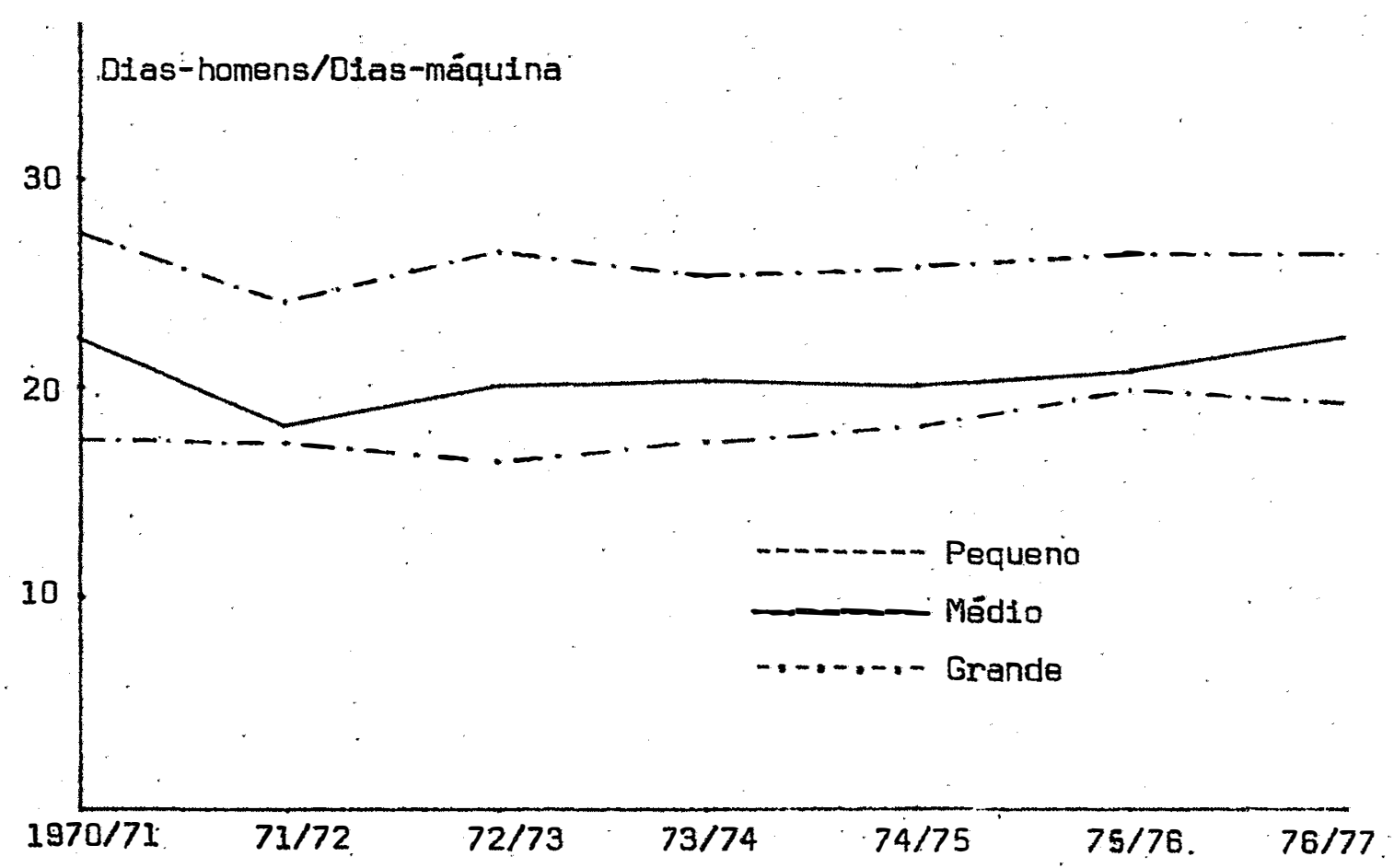

Figura 20 - Relação TRABALHO/TRATOR. FONTE: Resultados do. Modelo.

De maneira aparente, isto entra em conflito com adis cussão anterior que dizla ser o estrato dos pequenos produtores relativamente mals "poupador" de trabalho. Explica-se esta aparente contradição pelo fato de que, a despelto de no total ser verdadelra a afirmação, na relação especifica TRABALHO/TRATOR o mesmo não ocor re porque, ao mesmo tempo em que o estrato em questão "poupa" traba 1ho, ele igualmente o faz - e de modo mals acelerado - com os ser viços de máquinas. E isto devido ao fato do crescimento das suaș atividdades se verificarem principalmente em pecuária, e culturas pe. renes, atividades menos exigentes em serviços de mäquinas que as cul turas anuais (cuja área esgota-se para o estrato infertor logo no primeiro ano\}. 
109.

Uma indicação clara pode ser dada pela atividade de INVESTIMENTO em maquinaria, que ocorre no estrato inferior nos anos de 1973/74, 1975/76 e 1976/77, ainda não atingindo os limites permi tidos pelo coeficiente de adoção respectivo: em parte pode-se expli car tal fato por uma possível superestimativa da capacidade instala da em relação às exigências desse fator nos anos iniciais lo mesmo que se deu com a não-de-obra residente), e também pelo fato que nos últimos anos se acelera o crescimento das atividades de pastagens e de culturas perenes (estas em todos os perfodos). No estrato médio, o investimento deixa de ser feito apenas no ano de 1971/72, mas o limite de adoção é atingido em somente três anos consecutivos 1972/73, 1973/74 e 1974/75 - refletindo principalmente o crescimen to de culturas anuais nos três primeiros anos, e de culturas perenes (todo o período) e pastagens a partir de 1973/74. Quanto ao estrato superior, o investimento em maquinaria é realizado sistematicamente no perfodo, e nos limites de adoção la taxa de adoção é menor que nos demais estratos, todavia), sendo que a variável "dual", que fornece a receita marginal dos serviços de maquinaria é quase sempre crescente no período, com exceção do ano de 1974/75.

\subsection{3 - Animal de trabalho e outros fatores}

A relação ANIMAL/TERRA cresce no estrato superior, e decresce nos estratos médio e inferior, durante o perfodo (ver Tabe la 9 e Figura 21). 0 ano de 1975/76 é atipico no uso de animal de trabalino. 
O comportamento dinâmico nos três estratos está rela cionado: a) à exigêngia maior de animal de trabalho para o conjunto das culturas anuais, e das culturas perenes, sendo que as atividades de pecuária e pastagens praticamente não requerem esse fator; b) ao crescimento da terra total que, recorda-se, é bem maior percentualmente, nos estratos inferiores quando comparado com o estrato superior; c) às mudanças nas tecnologias moderna (motomecanizada) e tra dicional (animal, e motomecanizada e animal). Em termos comparativos, a cada ano, a mencionada relação é maior quanto menor o tamanho agregado das propriedades, com exceção do ültimo ano, em que os estratos médio e grande trocam as posições.

As relações TRABALHO/ANIMAL e TRATOR/ANIMAL podem ser vistas também na Tabela 9 e nas Figuras 23 e 22 , respectivamente. A estabilidade das relações indicaria a situação na qual os fatores são complementares, e mudanças nas mesmas em que direção ocorre a substituição. Na primeira relação, tomando-se como base os anos ini cial e final, o estrato grande substitui animal por trabalho,enquan to os dois outros estratos fazem o oposto, e com maior intensidade o estrato médio; na segunda relação, o comportamento é semelhante, e ainda mais nitido que o estrato grande substitui animal por trator, ao passo que os estratos restantes procedem ao contrário. Esses resultados sugerem que o estrato das grandes propriedades se moderniza, mas os estratos das pequenas e médias propriedades tendem a con seguir relações mais deterioradas neste sentido, principalmente o das médias propriedades. 
Tabela 9 - Relação ANIMAL/TERRA, em dias-animal empregados por hectare:- de terra utilizada, por estrato de área e por ano. Relação TRABALHO/ANIMAL, em dias-homens por dias-animal empregados, por estrato de área e por ano. Relaçäo TRATOR/ANIMAL, em dias-máquina por dias-animal empregados, por estrato de área e por ano.

\begin{tabular}{|c|c|c|c|c|c|c|c|c|c|}
\hline \multirow{2}{*}{ ANOS } & \multicolumn{3}{|c|}{ ANIMAL/TERRA } & \multicolumn{3}{|c|}{ TRABALHO/ANIMAL } & \multicolumn{3}{|c|}{ TRATOR/ANIMAL } \\
\hline & $\begin{array}{r}\text { Estra } \\
\text { Pequeno }\end{array}$ & $\begin{array}{l}\text { tos de } \\
\text { Médio }\end{array}$ & $\begin{array}{l}\text { área } \\
\text { Grande }\end{array}$ & $\begin{array}{l}\text { Estra } \\
\text { Pequeno }\end{array}$ & $\begin{array}{l}\text { tos de } \\
\text { Méd1o }\end{array}$ & $\begin{array}{l}\text { área } \\
\text { Grande }\end{array}$ & $\begin{array}{l}\text { Estra } \\
\text { Pequeno }\end{array}$ & $\begin{array}{l}\text { atos de } \\
\text { Médio }\end{array}$ & $\begin{array}{l}\text { ärea } \\
\text { Grande }\end{array}$ \\
\hline $970 / 71$ & $\begin{array}{c}1,35 \\
(100)^{a}\end{array}$ & $\begin{array}{r}0,53 \\
(100)\end{array}$ & $\begin{array}{r}0,37 \\
(100)\end{array}$ & $\begin{array}{l}20,28 \\
(100)\end{array}$ & $\begin{array}{l}43,17 \\
(100)\end{array}$ & $\begin{array}{l}54,31 \\
(100)\end{array}$ & $\begin{array}{l}1,15 \\
(100)\end{array}$ & $\begin{array}{l}1,90 \\
(100)\end{array}$ & $\begin{array}{r}1,97 \\
(100)\end{array}$ \\
\hline $1971 / 72$ & $\begin{array}{l}1,31 \\
(97)\end{array}$ & $\begin{array}{l}0,48 \\
(91)\end{array}$ & $\begin{array}{r}0,38 \\
(103)\end{array}$ & $\begin{array}{l}21,37 \\
(105)\end{array}$ & $\begin{array}{l}45,51 \\
(105)\end{array}$ & $\begin{array}{r}53,59 \\
(99)\end{array}$ & $\begin{array}{l}2,21 \\
(105)\end{array}$ & $\begin{array}{r}2,46 \\
\{129\}\end{array}$ & $\begin{array}{r}2,20 \\
(111)\end{array}$ \\
\hline $1972 / 73$ & $\begin{array}{l}1,22 \\
(90)\end{array}$ & $\begin{array}{r}0,53 \\
(100)\end{array}$ & $\begin{array}{r}0,47 \\
(127\}\end{array}$ & $\begin{array}{l}22,76 \\
(112)\end{array}$ & $\begin{array}{l}44,59 \\
(103)\end{array}$ & $\begin{array}{r}50,18 \\
(92)\end{array}$ & $\begin{array}{r}1,35 \\
(117)\end{array}$ & $\begin{array}{r}2,19 \\
(115)\end{array}$ & $\begin{array}{l}1,87 \\
(95)\end{array}$ \\
\hline $1973 / 74$ & $\begin{array}{l}0,99 \\
(73)\end{array}$ & $\begin{array}{r}0,56 \\
(106)\end{array}$ & $\begin{array}{r}0,52 \\
(140)\end{array}$ & $\begin{array}{l}28,13 \\
(139)\end{array}$ & $\begin{array}{l}45,86 \\
(106)\end{array}$ & $\begin{array}{r}45,11 \\
(83)\end{array}$ & $\begin{array}{r}1,59 \\
(138)\end{array}$ & $\begin{array}{r}2,22 \\
(117)\end{array}$ & $\begin{array}{l}1,76 \\
{[89]}\end{array}$ \\
\hline $1974 / 75$ & $\begin{array}{l}1,05 \\
(78)\end{array}$ & $\begin{array}{l}0,47 \\
(89)\end{array}$ & $\begin{array}{r}0,50 \\
(135)\end{array}$ & $\begin{array}{l}27,66 \\
(136)\end{array}$ & $\begin{array}{l}54,04 \\
(125)\end{array}$ & $\begin{array}{r}47,34 \\
(87)\end{array}$ & $\begin{array}{r}1,50 \\
(130)\end{array}$ & $\begin{array}{r}2,66 \\
(140)\end{array}$ & $\begin{array}{l}1,82 \\
(92)\end{array}$ \\
\hline $1975 / 76$ & $\begin{array}{r}1,51 \\
(112)\end{array}$ & $\begin{array}{r}0,90 \\
(170)\end{array}$ & $\begin{array}{r}0,64 \\
(173)\end{array}$ & $\begin{array}{r}19,29 \\
(95)\end{array}$ & $\begin{array}{r}29,69 \\
(69)\end{array}$ & $\begin{array}{r}37,36 \\
(69)\end{array}$ & $\begin{array}{l}0,97 \\
(84)\end{array}$ & $\begin{array}{r}1,41 \\
(74)\end{array}$ & $\begin{array}{l}1,39 \\
(70)\end{array}$ \\
\hline $1976 / 77$ & $\begin{array}{l}1,16 \\
\{86\}\end{array}$ & $\begin{array}{l}0,43 \\
(81)\end{array}$ & $\begin{array}{r}0,56 \\
(151)\end{array}$ & $\begin{array}{l}25,33 \\
(125)\end{array}$ & $\begin{array}{l}64,53 \\
(149)\end{array}$ & $\begin{array}{r}42,14 \\
(78)\end{array}$ & $\begin{array}{r}1,30 \\
(113)\end{array}$ & $\begin{array}{r}2,86 \\
(150)\end{array}$ & $\begin{array}{l}1,59 \\
(81)\end{array}$ \\
\hline
\end{tabular}

FONTE: Resuitados do Modelo.

(a) Os números entrè parênteses são Índices.

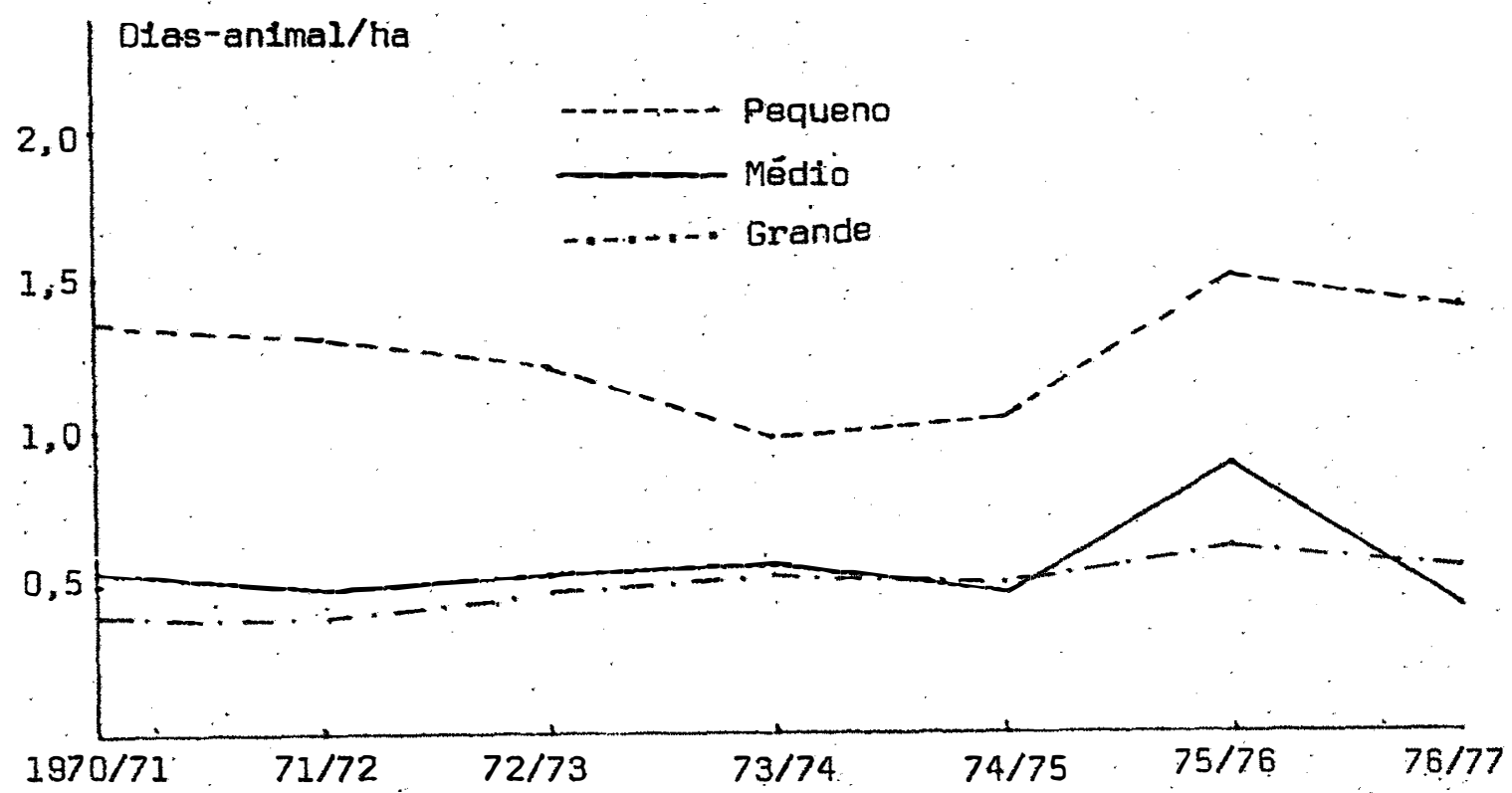

Figura 21 - Relação ANIMAL/TERRA. FONTE: Resultados do Modelo. 


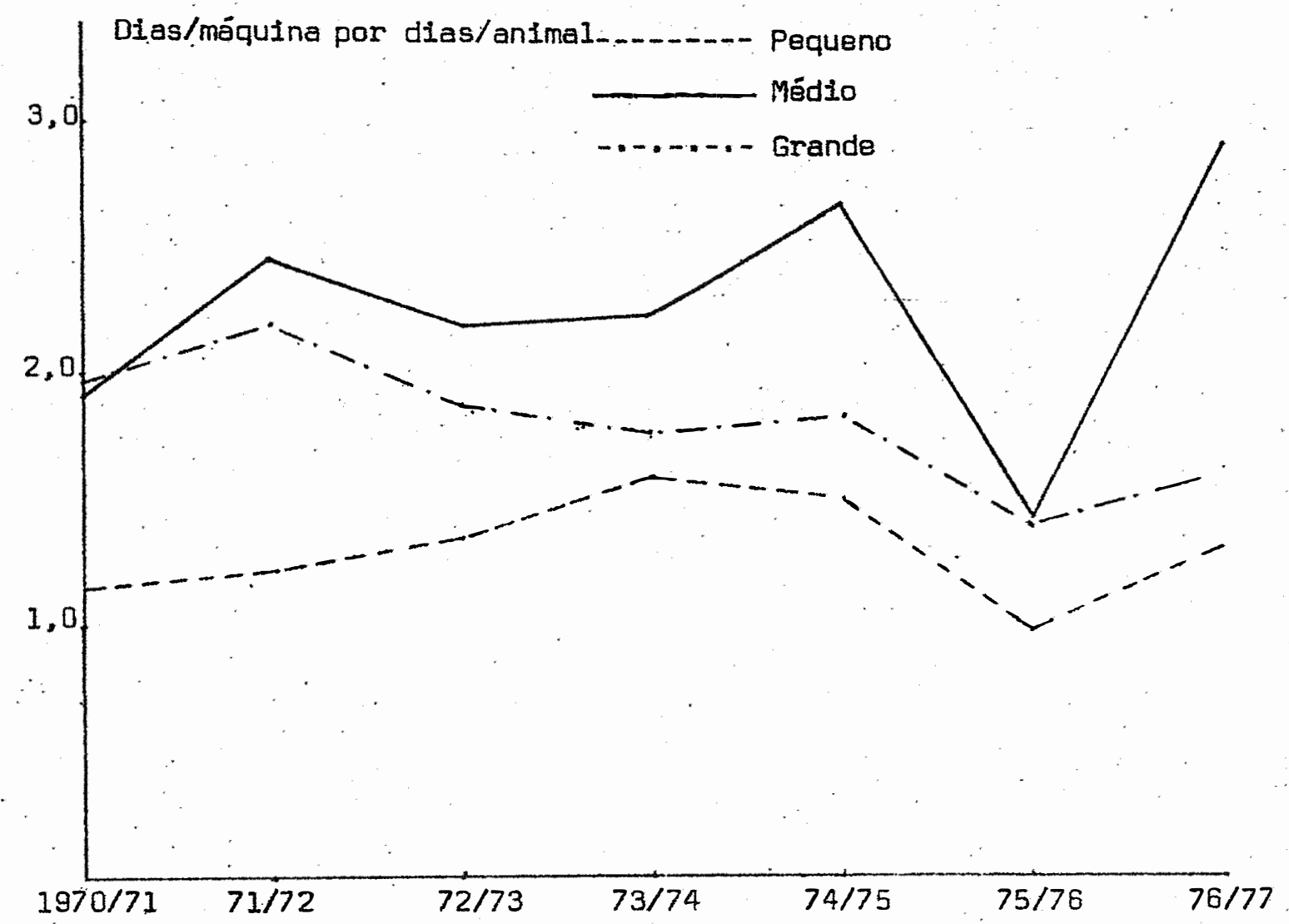

FIgura 22 - Relação TRATOR/ANIMAL.

FONTE: Resultados do Modelo.

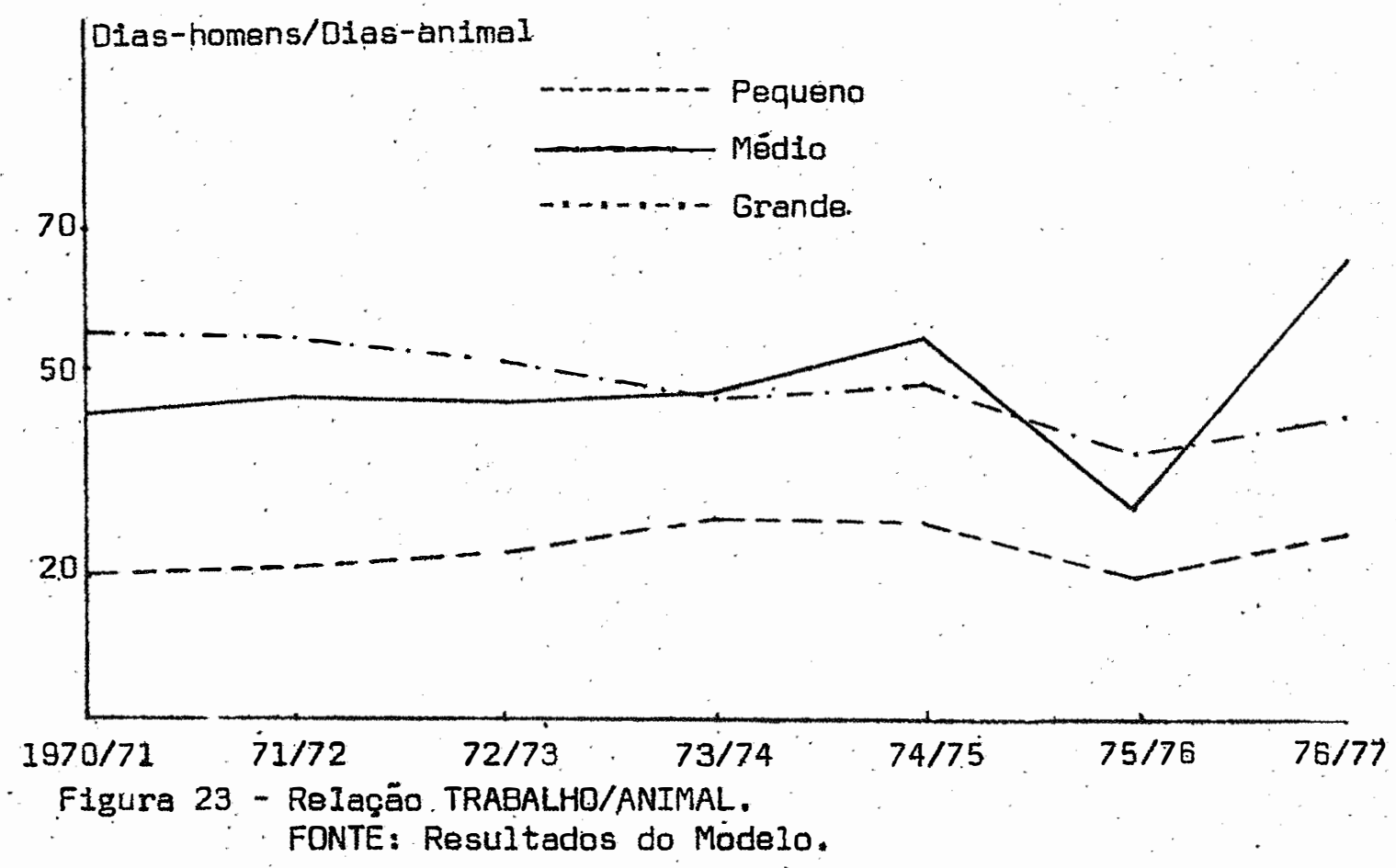


Em conclusão, tem-se que as relações de proporcionalidade entre os fatores de produção são indicadores do comportamento dos estratos de área, e muitas hipóteses podem ser testadas por seu intermédio. Porém, no presente modelo, a escassez de alternativas tecnológicas, o curto horizonte de planejamento, e informações pouco seguras das disponibilidades, resultou que as hipóteses levan tadas não recebessem confirmação suficientes.

\section{5 - Uso do Capital Financeiro}

Os fluxos financeiros presentes na matriz não foram rigorosos. A disponibilidade de capital monetário, na forma de capi tal de giro (CAIXA), crédito de custeio e de investimento estão pro vavelmente superestimados. Houve apenas um ano, o de 1970/71, e para o Bstrato médio somente, em que não foi acionado o vetor do custo de oportunidade do capital, representado pela remuneração paga por agências financeiras de captação de poupança no ano corrente. 0 custo de oportunidade do capital depende da disponibilidade prévia do caixa, da liquidez resultante da metade dos rendimentos causados pela venda dos serviços de mão-de-obra familiar e de leite,e do cré dito de custeio, na medida em que o custo de oportunidade do capital disputa os recursos financeiros com as atividades produtivas. A relação entre a quantidade de dinheiro aplicado no mercado de capitais (no caso, cadernetas de poupança) e a quantidade tomada de cré dito de custeio no último ano é de $1,46,1,78$ e 1,37, para os estra 
tos pequeno, médio e grande, respectivamente.

Enfim, no último ano todos os estratos aplicam mais recursos no mercado de capital do que recebem em dinheiro na forma de crédito de custeio para aplicação nas atividades propriamente pro dutivas. O desvio mostrado é desconcertante, e deve ser creditado muito mais a discrepâncias do modelo que à realidade de um fato que provavelmente não alcança tal expressão: esses recursos desviados pe lo custo de oportunidade do capital, lembra-se, não se referem aos ganhos com as atividades produtivas. A interpretação aponta no sentido que a disponibilidade de caixa - sem o crédito - já seria su ficiente para fazer frente às atividades produtivas, o que leva à su perestimativa, senão da própria disponibilidade de caixa pelo menos do seu mecanismo.

0 mecanismo do CAIXA, ou do capital de giro, que for nece o estoque inicial dos ativos financeiros disponíveis para os desembolsos realizados nas atividades produtivas, pode ser visto me lhor na relaçāo CAIXA/TERRA, da Tabela 10 e na Figura 24. 
Tabela 10 - Relação CAIXA/TERRA, em cruzeiros de 1970 por hectare de terra utilizada, por estrato de área e por ano.

\begin{tabular}{|c|c|c|c|}
\hline \multirow{2}{*}{ ANOS } & \multicolumn{3}{|c|}{ Estratos de Area } \\
\hline & Pequeno & Médio & Grande \\
\hline $1970 / 71$ & $\begin{array}{r}252,36 \\
(100)^{a}\end{array}$ & $\begin{array}{r}133,70 \\
(100)\end{array}$ & $\begin{array}{r}119,10 \\
(100)\end{array}$ \\
\hline $1971 / 72$ & $\begin{array}{r}262,54 \\
(104)\end{array}$ & $\begin{array}{r}176,19 \\
(132)\end{array}$ & $\begin{array}{r}152,99 \\
(128)\end{array}$ \\
\hline $1972 / 73$ & $\begin{array}{r}262,54 \\
(104)\end{array}$ & $\begin{array}{l}210,76 \\
(158)\end{array}$ & $\begin{array}{r}198,78 \\
(167)\end{array}$ \\
\hline $1973 / 74$ & $\begin{array}{r}284,65 \\
(113)\end{array}$ & $\begin{array}{r}265,63 \\
(199)\end{array}$ & $\begin{array}{r}245,19 \\
(206)\end{array}$ \\
\hline $1974 / 75$ & $\begin{array}{r}284,20 \\
(113)\end{array}$ & $\begin{array}{r}276,95 \\
(207)\end{array}$ & $\begin{array}{r}260,65 \\
(219)\end{array}$ \\
\hline $1975 / 76$ & $\begin{array}{r}271,33 \\
(107)\end{array}$ & $\begin{array}{r}286,72 \\
(214)\end{array}$ & $\begin{array}{r}293,16 \\
{[246]}\end{array}$ \\
\hline $1976 / 77$ & $\begin{array}{r}277,21 \\
(110)\end{array}$ & $\begin{array}{r}306,72 \\
(229)\end{array}$ & $\begin{array}{r}354,36 \\
(297)\end{array}$ \\
\hline
\end{tabular}

FONTE: Resultados do Modelo.

(a) Os números entre parênteses são Indices.

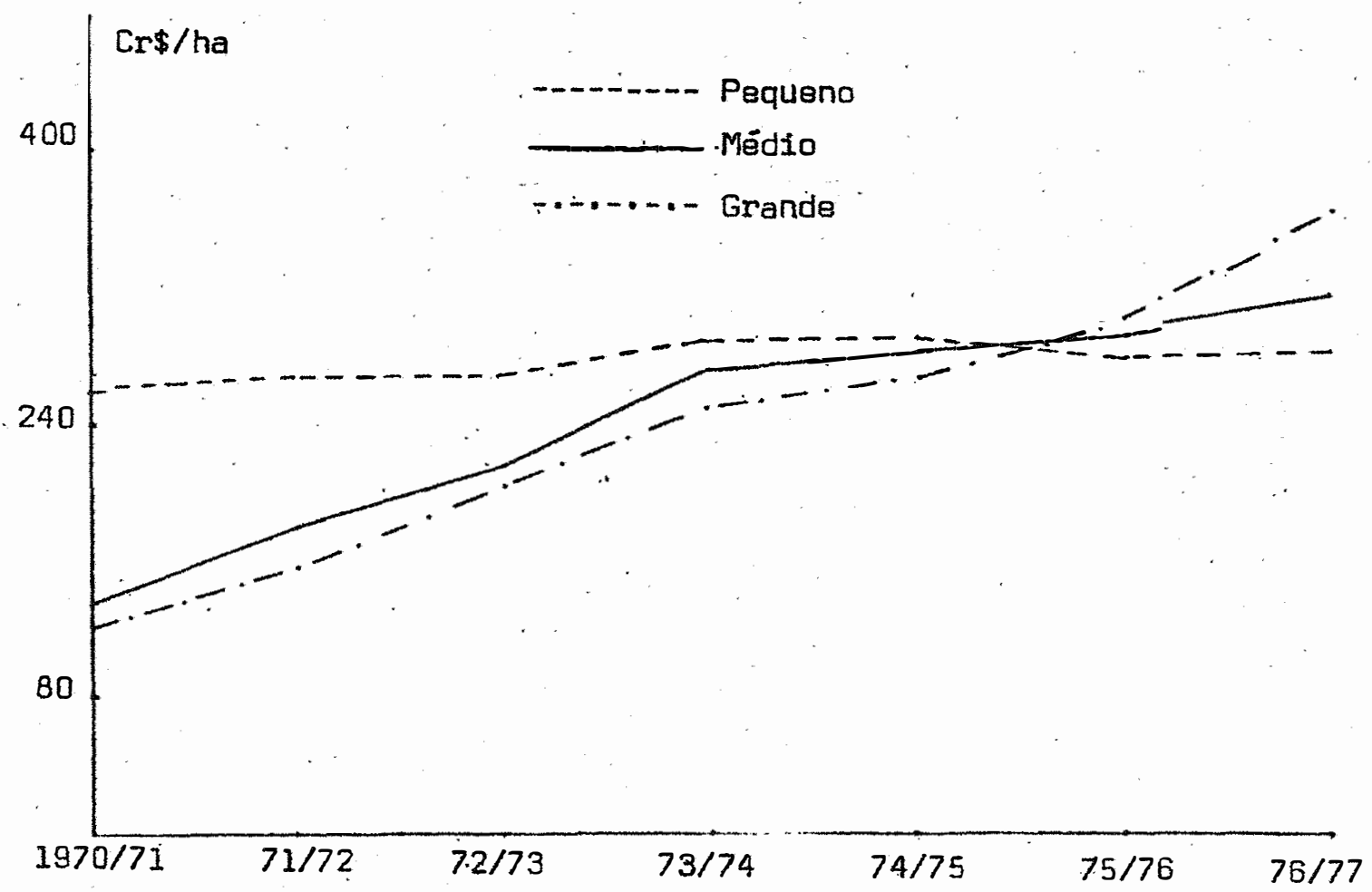

Figura 24 - Relação CAIXA/TERRA.

FONTE: Resultados do Modela. 
Até o ano de 1974/75, inclusive, em termos absolutos a cada ano, o dinheiro disponível em cruzeiros de 1970 por hectare utilizado é maior na ordem inversa do tamanho das propriedades; nos dois ültimos anos, a situação inverte-se totalmente. Num período cur to de tempo a existência de modificação tão drástica quanto esta tam bém é um indicador da superestimativa dos fluxos monetários. 0 cres cimento relativo é quase que invariavelmente crescente em todos os estratos no período. Chama a atenção a magnitude de tal crescimento porque a relação cresce 1,10 vezes para o estrato inferior, 2,29 ve zes para o estrato médio, e 2,97 vezes para o estrato superior. A margem de vantagem relativa do ültimo estrato para o primeiro é gran de para um período de 7 anos. A liquidez excessiva de um e a relati va descapitalização de outro encontram-se desproporcionalmente ajus tadas.

\section{6 - Retorno por propriedade}

A distribuição da renda média gerada por propriedade (ver Tabela 11 e Figura 25), dada por RETORNO/PROPRIEDADE, atesta o fato conhecido da esmagadora vantagem em favor das propriedades maio res. Considerando-se corretos os resultados do modelo, e mantida a mesma concentração da terra conforme os dados do INCRA, de 1972, a geração de renda em cruzeiros de 1970 é sempre crescente no período, e para todos os estratos. No estrato inferior ela passa de Cr\$ ... 3.660,00 por propriedade em 1970/71 para Cr\$11.671,00 por proprie- 
dade em 1976/77, com crescimento acumulado de $219 \%$; no estrato módio os dados mostram a passagem de $\operatorname{Cr} \$ 8.937,00$ para $\operatorname{Cr} \$ 33.168,00$ por propriedade no mesmo período, cujo crescimento alcança $271 \%$; nalmente, no estrato superior o percentual é da ordem de $410 \%$ passando de $\operatorname{Cr} \$ 42.603,00$ para $\operatorname{Cr} \$ 217.109,00$ no mesmo período.

Tabela 11 - Distribuição mëdia da renda, em cruzeiros de 1970 por propriedade, por estrato de área e por ano.

\begin{tabular}{|c|c|c|c|}
\hline \multirow[b]{2}{*}{ ANOS } & \multicolumn{3}{|c|}{ Estratos de Area } \\
\hline & Pequeno & Médio & Grande \\
\hline $1970 / 71$ & $\begin{array}{r}3.660 \\
(100)^{a}\end{array}$ & $\begin{array}{l}8.937 \\
(100)\end{array}$ & $\begin{array}{l}42.603 \\
(100)\end{array}$ \\
\hline $1971 / 72$ & $\begin{array}{l}3.712 \\
(101)\end{array}$ & $\begin{array}{l}10.100 \\
(113)\end{array}$ & $\begin{array}{l}50.192 \\
(118)\end{array}$ \\
\hline $1972 / 73$ & $\begin{array}{l}4.899 \\
(134)\end{array}$ & $\begin{array}{l}13.370 \\
(150)\end{array}$ & $\begin{array}{l}70.526 \\
(165)\end{array}$ \\
\hline $1973 / 74$ & $\begin{array}{c}5.652 \\
(154)\end{array}$ & $\begin{array}{l}16.305 \\
(182)\end{array}$ & $\begin{array}{l}81.227 \\
(191)\end{array}$ \\
\hline $1974 / 75$ & $\begin{array}{l}5.821 \\
(159)\end{array}$ & $\begin{array}{l}18.341 \\
(205)\end{array}$ & $\begin{array}{c}110.256 \\
(259)\end{array}$ \\
\hline $1975 / 76$ & $\begin{array}{l}8.605 \\
(235)\end{array}$ & $\begin{array}{l}26.942 \\
(301)\end{array}$ & $\begin{array}{c}169.977 \\
(399)\end{array}$ \\
\hline $1976 / 77$ & $\begin{array}{l}11.671 \\
(319)\end{array}$ & $\begin{array}{l}33.168 \\
(371)\end{array}$ & $\begin{array}{c}217.109 \\
(510)\end{array}$ \\
\hline
\end{tabular}

FONTE: Resultados do Modelo e INCRA, 1972.

(a) Os nümeros entre parênteses são Indices.

Observa-se que o crescimento da renda líquida por pro priedade gerada no período não difere extraordinariamente nos estra tos inferiores, mas é muito grande quando se compara com o crescimento do estrato super1or. Independente da magnitude dos números, não há razões para não se acreditar num crescimento dinâmico aproxí 
madamente equivalente, e nesse caso os extremos diferem entre si por quase duas vezes; mas em termos absolutos por cerca de vinte vezes no ültimo ano.

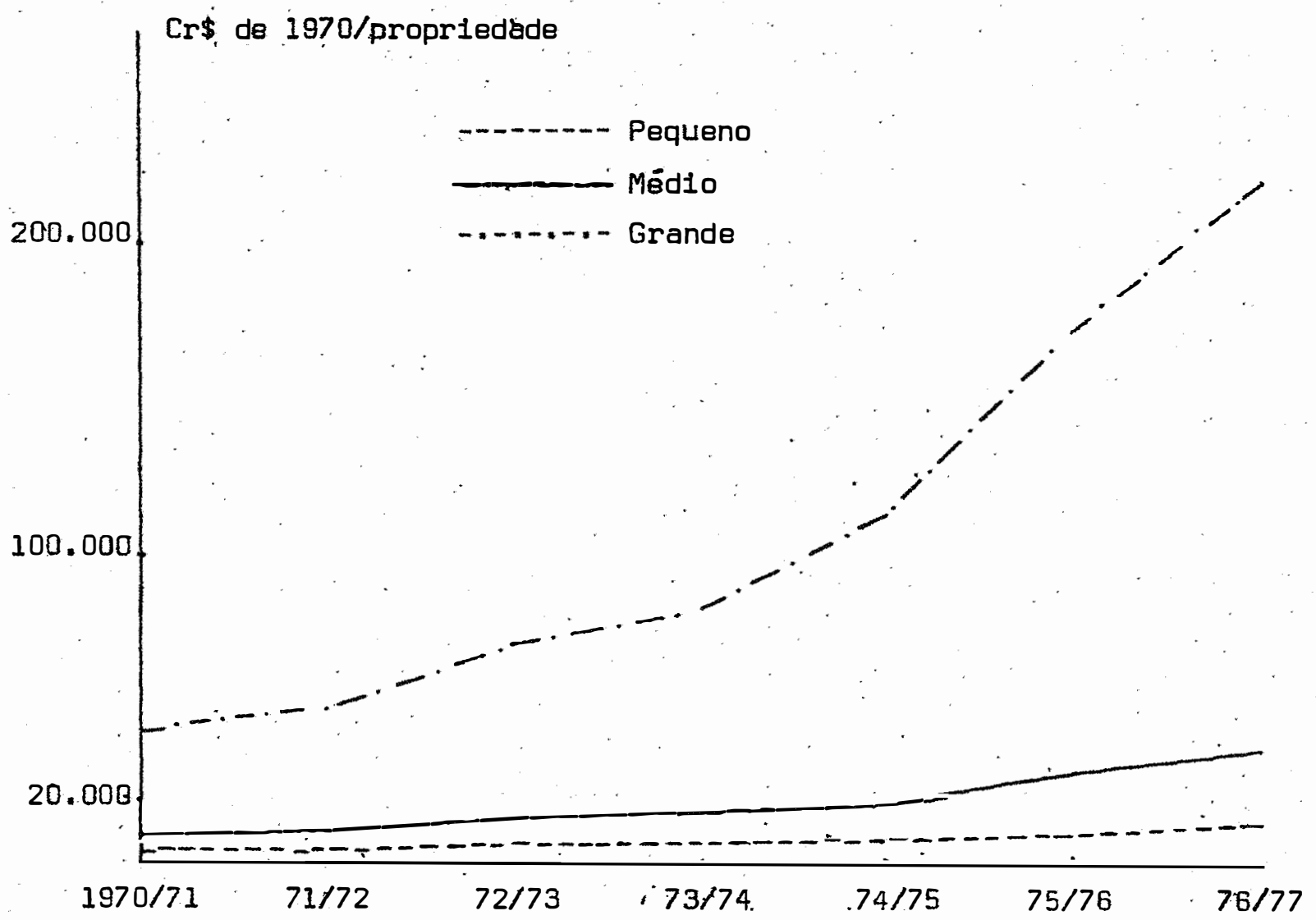

Figura 25 - RETORNO/PRDPRIEDADE. FONTE: Resultados do Modelo e INCRA; 1972. 


\section{7 - Confronto com os Dados Disponiveis}

0 confronto entre os resultados do modelo e os dados utilizados para a comparação (extraídos dos questionários do IEA)me rece comentário sobre os erros que um e outro possa conter,os quais são de três tipos:

(a) erros de especificação: são os erros devidos à própria natureza simplificada do modelo em relação à realidade, visto que necessariamente se procede a determinado nível de abstração, o que le va à omissão de variáveis;

(b) erros de variáveis aleatórias: são os erros causados por si tuaçōes imprevisíveis que ocorrem ao acaso, e que não foram conside rados pelo modelo, como por exemplo o efeito de condiçōes climáticas, e outras;

(c) erros de observação: são os värios erros ocasionados duran te os levantamentos de dados (de precisão, de qualidade, etc.), cuja magnitude é desconhecida.

Recorda-se também que a significância dos dados do IEA diminui quando se está ao nível dos estratos de área. Somente a partir dos anos recentes é que se estabeleceram limites com variância estatística definida a nível das DIRAs, conforme se afirmou em outra secção.

A comparação dos resultados do modelo com os dados reais só foi possível, nos estratos, para as seguintes atividades: algodão, arroz, café, cana, citrus, feijão das águas e da seca, mi- 
tho e soja. As atividades que não sofreram confronto direto são as de tomate, batata das águas e da seca, mandioca (estas podendo no entanto o serem a nf́vel de DIRA), todas as de pecuária (suinocultura tipo carne e tipo banha, bovinocultura de corte, de leite $C$ e de leite $B$ ), e pastagens (natural e artificial). Toda a análise será baseada partindo-se do pressuposto que os dados estimados pelo IEA possuem realismo absoluto.

Para os casos de confronto utilizar-se-á de um teste näo exatamente estatístico sugerido por DAY (1963). Trata-se de um teste com muitas imperfeições, e "rigoroso" para o acompanhamento do modelo, mas devido à sua facilidade, e aos poucos graus de liberdade para se proceder a estatísticas formais, servirá como um substituto destas.

0 teste compara as variações em torno da média dos dados reais com os hiatos entre estes e os resultados do modelo nos pontos relevantes. Tem-se:

$$
\sum_{t=1}^{n}\left[x_{1}(t)-\frac{1}{n} \sum_{t=1}^{h} x_{1}(t)\right]^{2}
$$

onde: $h$ = número de anos $(1970 / 71, \ldots, 1976 / 77)$;

$$
\begin{aligned}
x_{1}= & \text { hectares plantados da atividade } \underline{1} \text { (algodão, café, etc. )no } \\
& \text { tempo } \underline{t} .
\end{aligned}
$$

A expressão (1) é a soma dos quadrados dos desvios em relação à média no período h. A esta expressão dá-se o nome de "Variação Total". Em seguida tem-se: 


$$
\sum_{t=1}^{h}\left[x_{1}^{*}(t)-x_{1}(t)\right]^{2}
$$

onde: * = solução ötima do modelo.

A expressão (2) fornece a soma dos quadrados dos des vios da solução do modelo em relação aos dados realmente observados. A esta expressão dá-se o nome de "Resíduo não Explicável", que é uma medida do quanto o modelo se distancia do ponto verdadeiro.

$$
\text { Subtraindo-se (2) de (1) chega-se a "Variação Expli- }
$$

cada". Fazendo-se:

$$
\frac{\text { Variação Explicada }}{\text { Variação }} \times 100
$$

tem-se, em (3), a "Porcentagem de Variação Explicada", que pode ser, inclusive, negativa, entende-se daí que as estimativas do modelo ex plicam menos que nada sobre os dados reais; isto obviamente não é verdadeiro porque, no mínimo, as estimativas não explicariam nada.

$$
\text { Existem outros métodos de avaliação a que AHN (1972) }
$$

faz apenas referência. O próprio DAY (1963) assinala que desenvolvi mentos nesse sentido precisam ser feitos, e cita algumas dificuldades na aplicação de testes mais satisfatórios para validar os resul tados do modelo.

Para uma avaliação parcial utilizando o mátodo descrito acima escolheu-se algumas atividades. As atividades escolhidas são: algodão, batata da seca (a anível de DIRA apenas), café, feijão das águas e milho. Destas, duas ocupam parcelas significati- 
vas em todos os estratos em se tratando de área plantada de culturas anuals, quals sejam, o algodão e o milho: ambas possuem duas tec nologias. O café fol escolhido por causa também dé sua importância na regläo, e por ser o representante das culturas perenes, possulndo uma ünica tecnologia. O feljão das águas, com duas tecnologias, pelo fato de ser uma cuttura alimentar. E finalmente batata da seca pelo fato de ser cultura bastante especlalizada, e com dados disponÍvels apenas a nÍvel de DIRA, a exemplo de tomate, batata das águas e mandioca.

Pela Tabela 12 e Figura 26 pode-se acompanhar o comportamento do algodão. Repare-se na linha que fornece as varlações dos dados observados (IEA) para os três estratos la Tabela e as F1guras correspondentes estão dispostas na forma de Indices das áreas plantadas tendo o valor observado de $1970 / 71=100$ ). Considerando- se tão somente as varlações para clma e para balxo de um ano para outro, nota-se que das sels varlaçöes permitidas em nenhum caso hou ve concordâncla simultânea na tendêncla por elas mantidas. Quer dizer, em momento algum houve qualquer semelhança no comportamento dos três estratos tomados confuntamente. Já 1sso ocorre com os resultados do modelo em três casos que compreendem a passagem no intervalo aberto de $1971 / 72$ a $1974 / 75$.

No estrato pequeno, a aplicação do teste revelou que os desvios dos resultados do modelo em relação ao observado apresen tam um resfduo malor que a varlação total em torno da média. Pelo gráfico nota-se que só na passagem $1974 / 75$ para $1975 / 76$ as tendên- 
clas de crescimento diferem entre si, mas também houve subestimat1va do modelo até o ano 1972/73, quando acontece um decréscimo abrup to Inão capturado pelo coeficlente de flexibilidade, dado em termos médios) a partir do qual o modelo segue com superestimativa; nota- se que a passagem em que se conflitam as tendênclas contribui para a melhor aproximação de ambas.

No estrato médio, a tendêncla de crescimento é a mes ma até 1974/75 com superestimativa pelo modelo, quando então acumulam-se funtos dols problemas: queda abrupta entre os pontos observa dos acompanhada de tendênclas desiguals. O Intervalo do penúltimo pa ra o ültimo ano apresenta também tendênclas diferentes mas de modo suave. O teste Igualmente não concede nenhuma explicação nesse caso. No estrato grande, o teste fornece aproximadamente 25\% de explicação, e nesse caso as tendênclas são conflitantes por três anos seguidos, mas, conforme mostra o gráfico, os resultados do modelo não fogem em demasia da linha dos dados rea1s. Interessante é que a passagem problemática para os demais estratos, de 1974/75 para 1975/76, está quase perfeita nesse caso.

Para a DIRA, esta segue mais de perto o estrato supe rlor que tem a maior área plantada. O teste indica que não há explí cação.

Na Tabela 12 e Figuras $27,28,29$ e 30 as demals at vidades produtivas escolhidas podem ser observadas. 


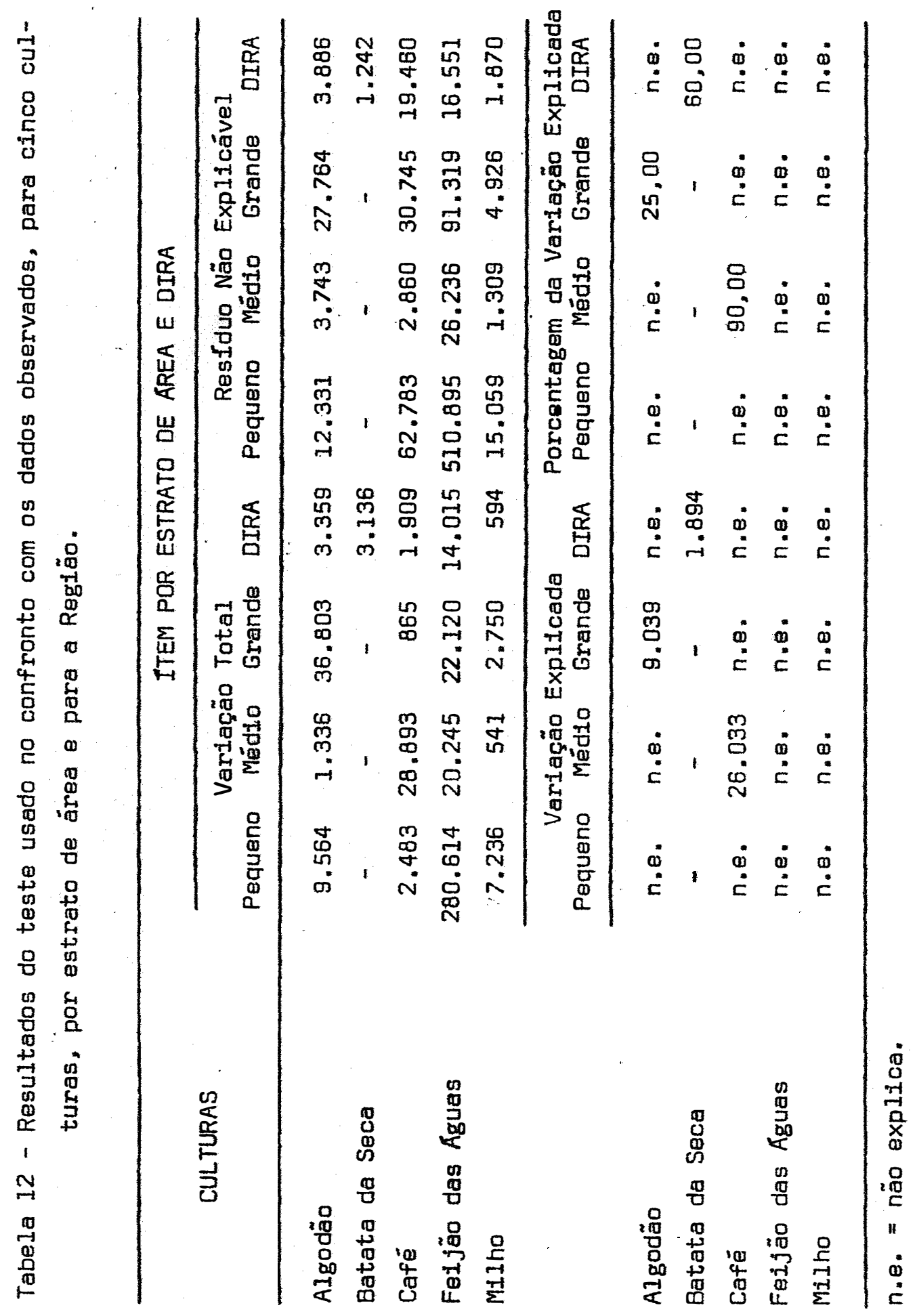




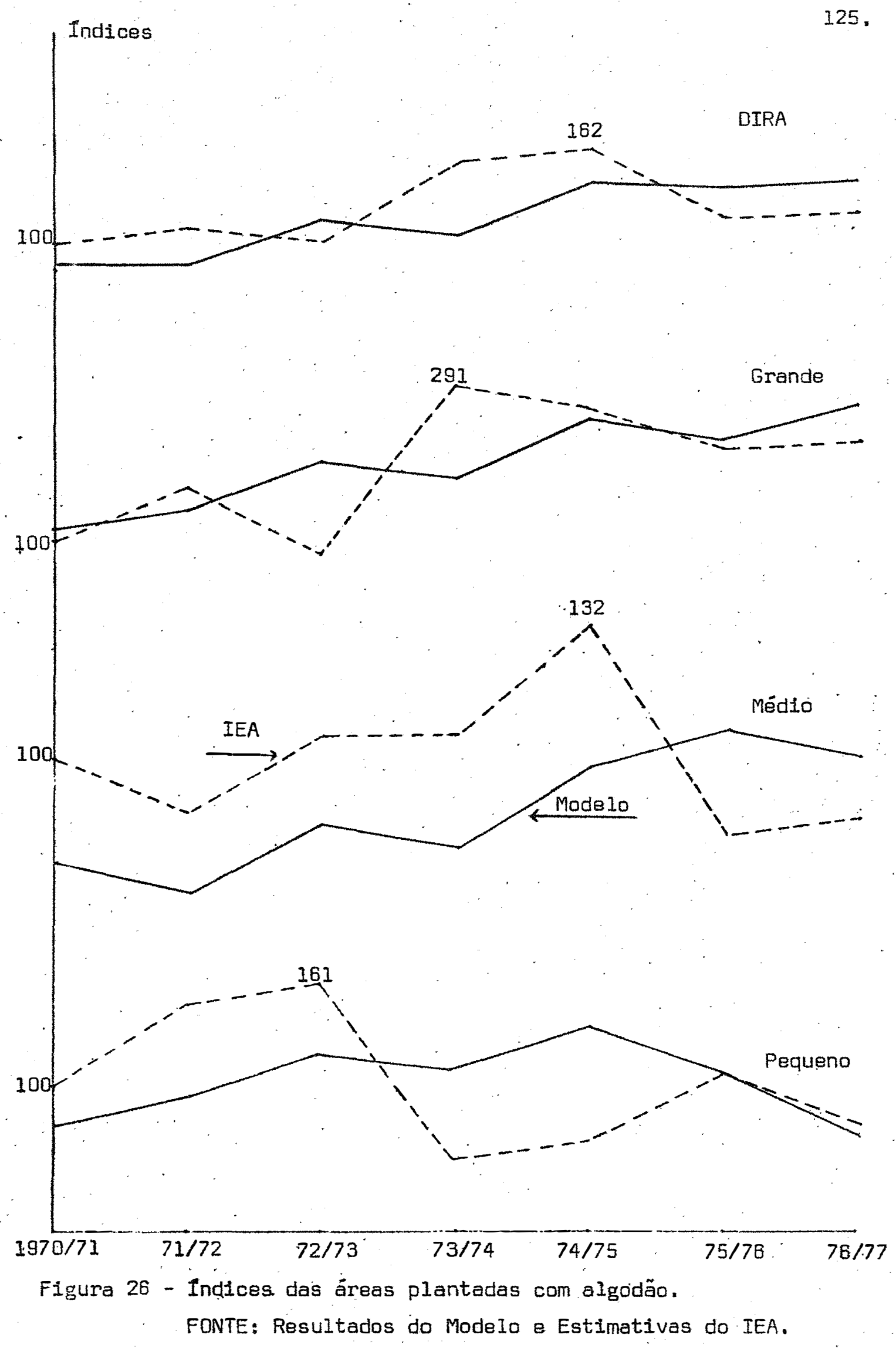


126.

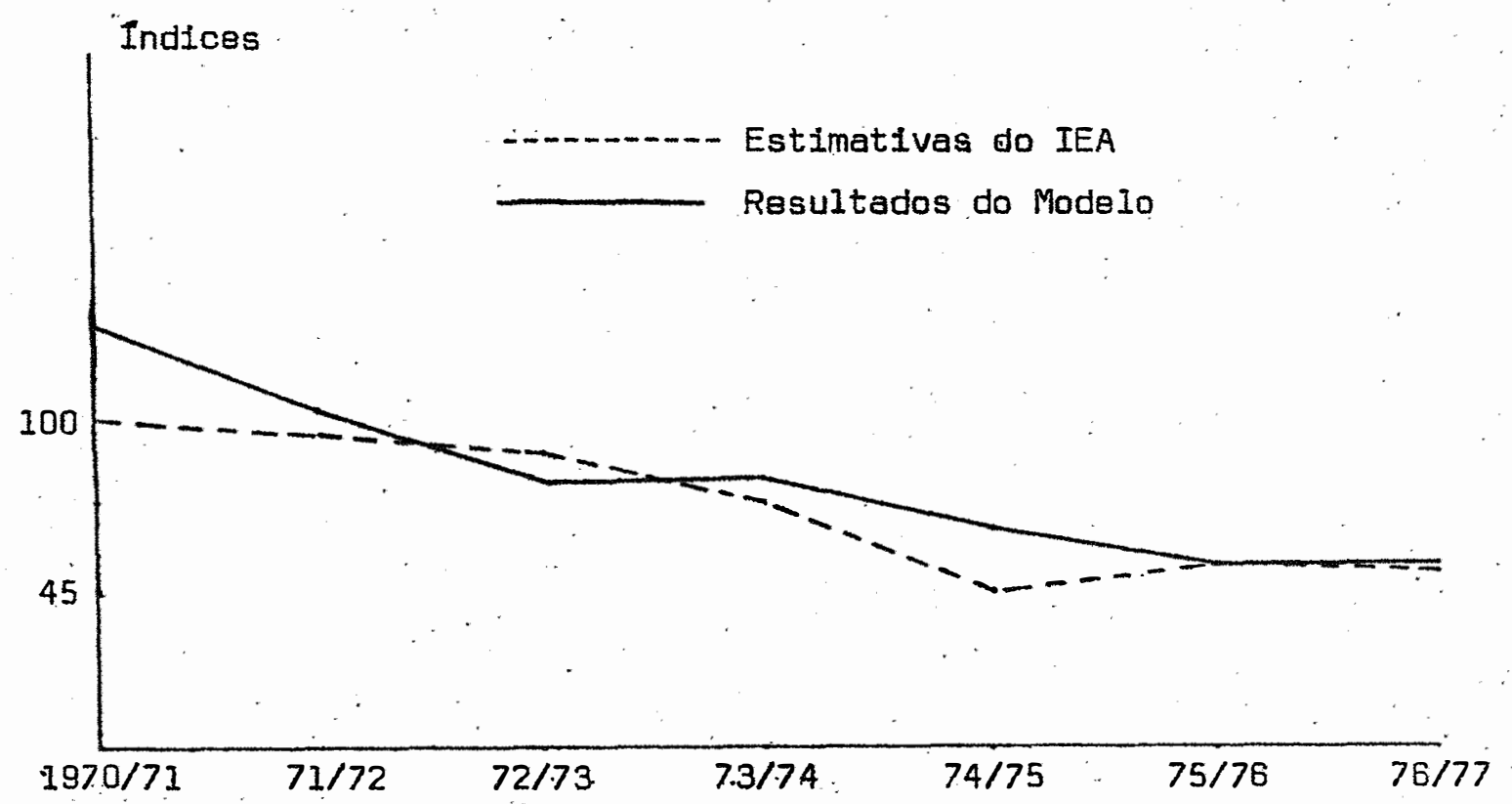

Figura 27. - Indices das äreas plantadas cam batata da seca na DIRA. FONTE: Resultados do Módelo e Estimativas do IEA. 


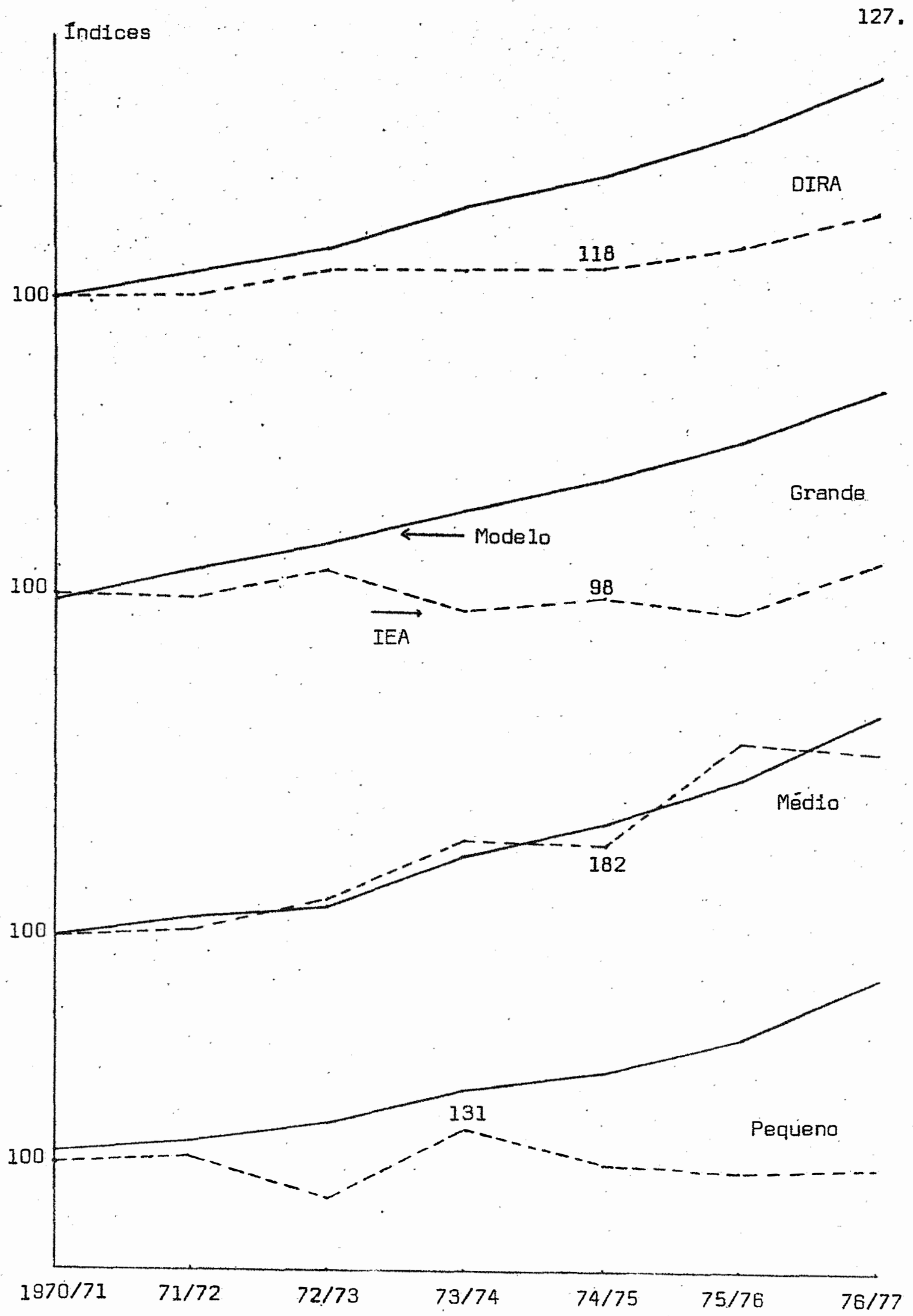

Figura 28 - Indices das áreas plantadas com café. FONTE: Resultados do Modelo e Estimativas do IEA. 


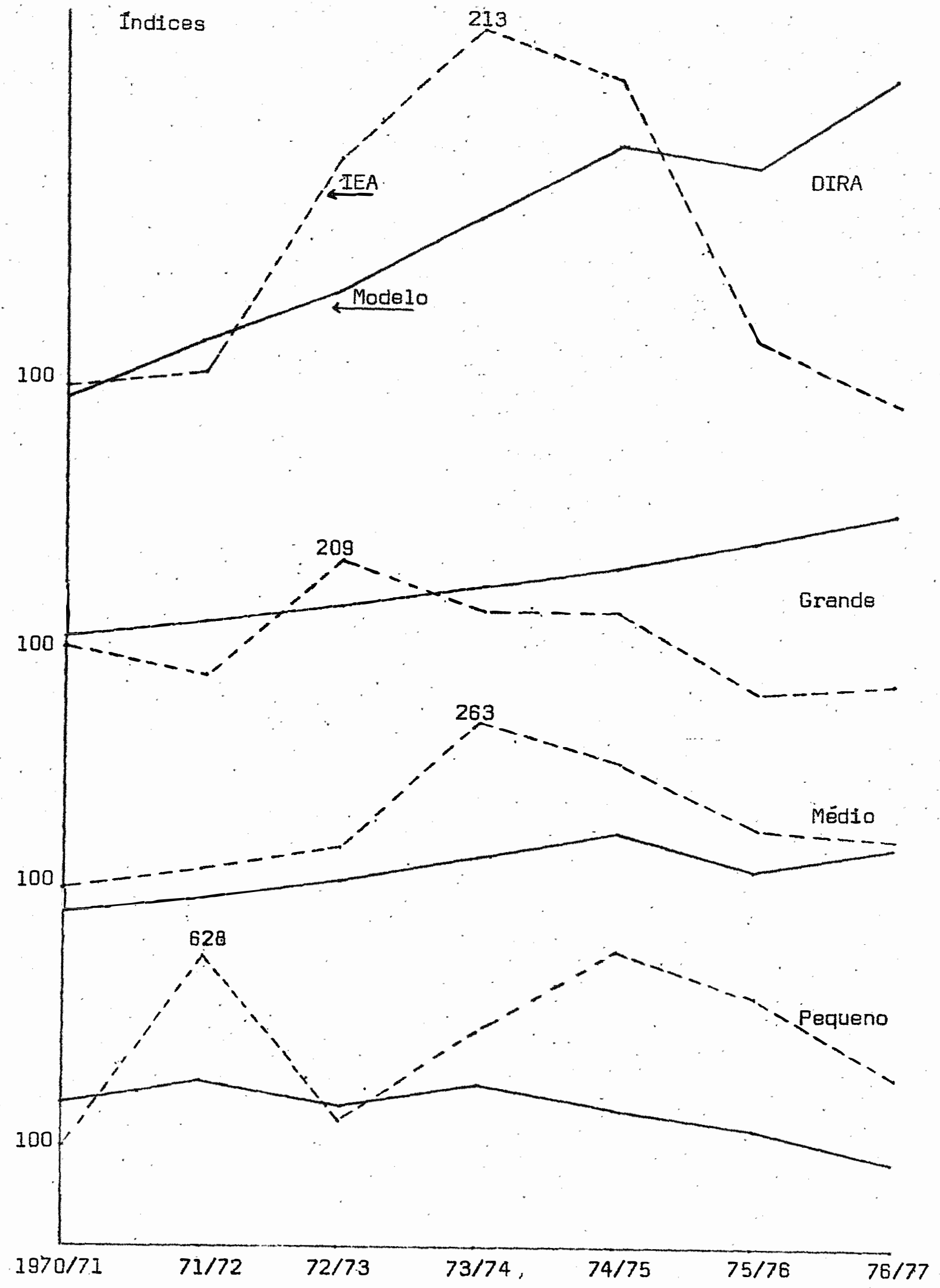

Figura 29' - Indices das áreas plantadas com feijão das águas. FONTE: Resultados do Modelo a Estimativas do IEA. 


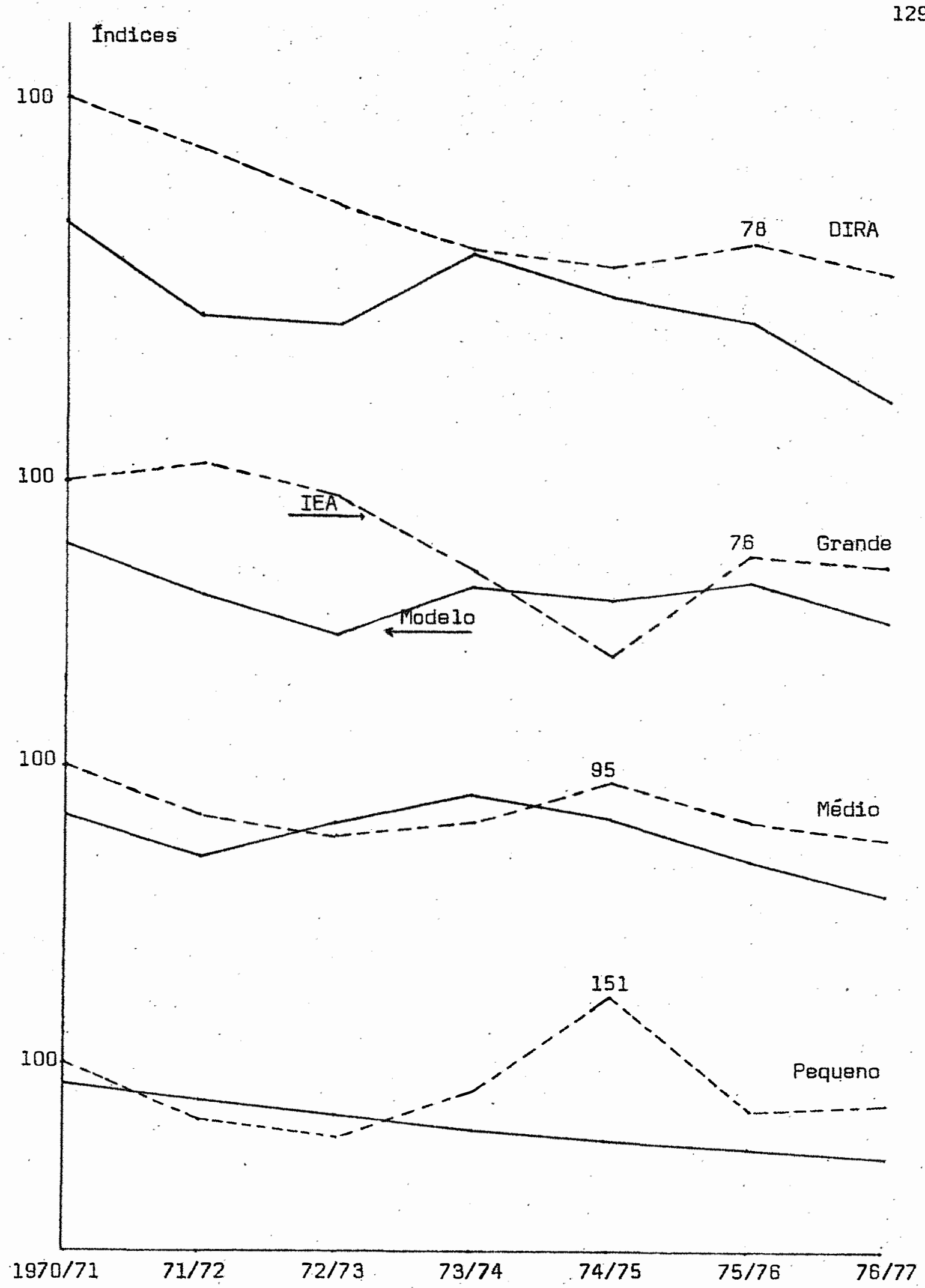

Figura 30 - Indices das áreas plantadas com milho.

FONTE: ResuItados do Modelo a Estimativas do IEA. 
Tenta-se a seguir uma visão mais abrangente sobre al guns pontos das discussōes anteriores ao mesmo tempo que se enfatiza aqueles de maior importância. De infcio, tem-se a comentar o pro blema das prováveis superestimativas das restriçōes, as quais permi tiram uma flexibilidade maior do que se acredita possivel na prática. Há dois tipos de superestimativas. O primeiro tipo relaciona-se à superestimativa propriamente dita, em termos de capacidade disponível: o caso mais flagrante é a do estrato pequeno com mão-de-obra familiar e residente e serviços de máquinas, principalmente; este ültimo devido talvez à forma de cálculo do equivalente-trator, e os serviços de mão-de-obra pela ausência da competição regional e a re tirada de atividades exigentes nesse fator, como fruticultura tempe rada, que se concentra no estrato em questão. 0 segundo tipo de superestimativa é creditado à pressuposição de oferta completamente elástica de muitos dos fatores variáveis, como fertilizantes, insumos modernos, serviços de mão-de-obra contratada, e outros;esta pres suposição, Juntamente com a excessiva liquidez do sistema, dada pelo fluxo monetário-financeiro, redundou nas superestimativas do segundo tipo. o tratamento com limites impostos também não é aconselhá vel porque os dados a respeito ou não existem, ou não consideram de modo suficiente a sazonalidade agrícola, a exemplo daqueles sobre mão-de-obra contratada, o que os tornam inüteis para os propósitos que se deseja. A solução sería equações de oferta desses fatores a nível regional, conjugado com a competição regional, além de uma re visão das atuais disponibilidades, principalmente as monetárias. 
O presente modelo ateve-se próximo à versão dinâmica do modelo de utilização da terra de Henderson. Neste, o papel funda mental dos coeficientes de flexibilidade é ressaltado, ao lado de li mites de terra, no processo de mudanças no uso da terra e na composłção das atividades produtivas.

A regra básica é a de maximização de receitas líquidas relativas, em que "a oferta dos produtos agrícolas respondem di retamente às mudanças de posições af verificadas, e apenas indireta mente às mudanças absolutas nos preços respectivos" 6/.

Dentro dessa perspectiva, a oferta dos produtos agrí colas a curto prazo, no caso das culturas anuais, não seria diferen te daquela proporcionada por uma análise paramétrica no atual modelo em que se variasse o preço de um determinado produto. Isto deve-se que (a) estas atıvidades possuem os coeficientes técnicos mais confiäveis, (b) contam, nos estratos pequeno e médio, com limites de terra bem estabelecidos e (c) as superestimativas sustentam esse prog nóstico porque, por um lado, garantem que a tecnologia estä disponf vél até o limite fornecido pelo coeficiente de flexibilidade, e por outro lado, quando há elasticidade no uso da terra (para o estrato grande), o custo de oportunidade dado ao capital impede que se tenha sempre limites superiores para todas as atividades produtivas, devido à liquidez do sistema.

6/ DAY (1963) 
Não se tem a mesma garantia em se tratando da oferta de produtos como o café e a laranja (culturas perenes); nesse caso, pela ausêncla de erradicação, e pela maior liberdade de crescimento, somadas às dificuldades no tratamento com culturas perenes (geadas no café, e crise de produção na laranja), provavelmente as distorções foram maiores. No caso das atividades pecuärias, ocorre praticamente o mesmo verificado com culturas perenes, onde houve relativa liberdade de crescimento, e em que a exigência maior se verifica nos serviços de mão-de-obra, sendo os demais requisitos traduzidos na forma de variáveis expressas em valores monetários. Em contrapar tida, a demanda por alguns fatores de produção ficou seriamente pre judicada $?$ ?

0 estrato pequeno ocupa toda a terra do tipo I (para culturas anuais\} de que dispõe, durante todo o perfodo. E justamente por causa desse fato é onde se localizam melhor as mudanças na composição das atividades que af se desenvolvem, porque não hã cres cimento ou expansão das culturas anuals como um todo. O crescimento extensivo é feito com base nos outros dois tipos de terra (para cul turas perenes e pastagens); por conseguinte, o estrato pequeno fol

I/ Em todos os casos em que havia interesse especial, tratou-se de proceder a expedientes que anulassem os maiores inconvenientes. Assim, para a demanda de fertilizantes (ROESSING, 1978) incluiu- se atividades extras que dessem conta dos diferentes rendimentos a vários níveis de adubação; no caso da demanda por crédito de custeio (PINAZZA, 1978) atendeu-se aos cuidados necessärlos na análise dos resultados, focalizando a capacidade potencial de ca da estrato na demanda por crédito face à estrutura própría de cá da um deles, e à mobilidade dos fatores de produção. 
o que apresentou maior número de culturas anuals que sofreram decrés cimo no período. Também neste mesmo estrato é que o crescimento da relação TRABALHO/TERRA fol a menor entre os três estratos de ärea, indicando ser o estrato comparativamente menos absorvedor de trabalho por hectare de terra total ocupada em termos dinâmicos. Acresce que os investimentos em maquinaria sempre foram reduzidos ou ausentes neste estrato, a confirmar que as melhores terras estavam já intensamente ocupadas. De maneira geral, os indices de evolução do estrato pequeno em termos de alterações na proporcionalidade entre os fatores de produção (no sentido da modernização) e os de produti vidade, colocam-no quase sempre numa posição intermediáría entre os estratos médio e grande. Este ültimo é o que obteve os melhores resultados neste sentido.

0 estrato médio, ao contrário da expectativa, ocupa quase que invariavelmente a posição mais estável entre os estratos de àrea ao longo do período. Exceto para algumas exceçōes, como na atividade de investimento em maquinaria, a tendência tem se mostrado de maneira geral no sentido de igualar as relações de proporcionalidade entre os fatores de produção nos estratos, em termos absolutos. Isto significa que enquanto o estrato médio se mantém num ní. vel de relativa estagnação técnica, os demais estratos avançam com maior dinamismo, apesar do fato já largamente enfatizado das restrí ções de terra de melhor qualidade para o estrato inferior. Dado que o estrato médio teve possibilidade de ocupar terra do melhor tipo nos anos iniciais, e que igualmente seu crescimento é o maior em ter 
ras para culturas perenes, e a pouca exigência em coeficientes técnicos das atividades pecuärías, é forçoso admitir que a eficiência com que o estrato inferior modifíca sua composição de atividades é maior do que a eficiência do estrato médio. De outra forma sería im possível explicar mesmo alguns resultados nos quais aquele suplanta este, em modernização e crescimento da produtividade, sempre referi dos aos recursos efetivamente utilizados.

No estrato superior verifica-se a maior liberdadepos sIvel no que se refere às mudanças. A exceção das atividades de investimentos em máquinas, ele obedece quase que exclusivamente à regra da receita lfquida relativa, restrita pelos coeficientes de fle xibilidade.

Pelos resultados do modelo, na análise dos recursos efetivamente utilizados, as tendências mostradas são demasiadamente suaves, mas parece razoável (mantidas as precauções) a seguinte dị posição: o estrato médio é o mais estável, onde as mudanças ocorrem mais lentamente; o estrato grande é o que apresenta maior dinamismo porque sua facilidade em dispor dos recursos necessários o permite: e o estrato pequeno, este utiliza mais "racionalmente" os seus recursos, visto que é o estrato onde a pressão neste sentido é maior, mas que enfrenta problemas derivados de sua própría constituição, quais sejam, a baixa capacidade de utilização da mão-de-obra familiar e residente, e a disponibilidade esgotada das terras de melhor qualidade, que dificultam sua formação de capital na forma de inves timentos em maquinaria, etc. 
E evidente que a anälise anterior, pelo modo como foi obtida, inspira cuidados porque origina-se de resultados que abrigam distorções cuja magnitude ẽ difícil de avaliar. Dentre estas o maior destaque cabe às opções tecnológicas, seguida da ausência de competição regional e da superestimativa das disponibilidades.

Quanto à presença de alternativas tecnológicas, veri fica-se que ela não fol marcante, uma vez que grande parte das atividades produtivas realizadas contou com uma ünica tecnologia. E o caso, prr exemplo, das atividades pecuárias, e das culturas penenes como o café e a laranja, e mais cana, mandioca e arroz, para citar aquelas que tem maior relevo no emprego de recursos. Entre as que contam com duas tecnologias (o que difere nas tecnologias é basicamente o uso de maquinaria versus animal de trabalho e/ou mão-de-ctra, e o custo em insumos modernos, tudo resultando em rendimentos diferentes), estão o algodão, o milho, batata das águas e feijão das àguas e da seca.

Para o algodão, que tem expressiva participação na agricultura regional, a tecnologia I (tradicional) aparece uma única vez na solução ótima do ano 1975/76, para os estratos pequeno e médio, e nos dois ültimos anos para o estrato grande, neste dividin do-se entre tecnologia I e II. Esta cultura, pelos resultados obtidos, francamente se utiliza da tecnologia mais moderna, devendo-se imputar o ocorrido em $1975 / 76$ pela baixa no preço do produto que es colhe a estrutura de custos mais favoráveis nessas condições. 
No caso do milho, essa cultura apresentou decréscimo de área nos três estratos, sendo também significativa sua participa ção em área plantada na região. Em termos de tecnologia, o estrato inferior utiliza-se sempre da tecnologia II (moderna); o estrato mé dio apresenta uma evolução bem caracterizada nesse sentido, inician do-se com tecnologia I, que passa a dividir conjuntamente com a II. e com predominância desta nos últimos anos: o estrato superior apre senta-se sempre com tecnologia tradicional. Esta cultura perde importância relativamente na região, e o estrato sob maior pressão o inferior - produz sempre com a tecnologia mais avançada ao mesmo tempo que apresenta o maior decréscimo; o estrato médio tem um comportamento coerente; e o estrato superior decresce no mesmo ritmo que o médio, mas com tecnologia mais atrasada para atender a demanda de expansão que ele pode fazer em outras culturas. A esse respei to, nota-se que à medida que a pressão sobre a terra é maior no estrato médio (a partir de $1972 / 73$ ), este passa a se tecnificar.

Batata das águas tem um comportamento semelhante nos três estratos mas sua importância em área plantada é menor, principalmente nos estratos superiores. O comportamento referido diz respeito à tecnologia porque, no confronto com os dados, esta cultura, a nível de DIRA, teve péssimo desempenho.

No caso de feijão das águas e da seca também sua importância em área plantada é pequena. Praticamente não há mudanças na tecnologia, que opera com frequência com a tecnologia tradicional. 
A questão da mudança tecnológica é um traço essencial do comportamento dos estratos e, para o presente modelo, julgou-se erradamente que o grande número de atividades, em que apenas as mais flagrantemente diferenciadas receberiam uma opção adicional de tecnologia, seria suficiente para proporcionar a flexibilidade na dire çao das mudanças que se esperava ocorrer. Mas o que de fato aconteceu foi que esse procedimento simplificado não se mostrou capaz de proceder a mudanças nitidamente perceptrveis. As escolhas mostram-se muito mais sensíveis quanto maior forem as alternativas (ou processos produtivos) dentro de uma mesma atividade produtiva (ou pela in. clusão de novas atividades\} do que o permitido apenas pelo número absoluto de atividades envolvidas, cuja elasticidade estende-se até os limites fornecidos pelos coeficientes de flexibilidade. A respei to desses últimos, deve-se notar que o modo como foram calculados. tomando-se as médias das variações para cima e para baixo,muitas ve zes não consegue acompanhar as oscilações de fato ocorridas, ficando-se em super ou subestimativas; por outro lado, aumentando-se sua amplitude poderia ocorrer o problema de distanciamento da realidade em poucos períodos, conforme a tendência bastante comum de especialização da programação linear. No trabalho de Heidhues, este autor dispensa o uso dos coeficientes de flexibilidade, mas nesse casotra ta-se do acompanhamento da evolução de uma única propriedade, e com disponibilidades rigorosamente estabelecidas, a um nível que dificil mente se obteria quando se considera toda uma região. 
Isto leva diretamente a considerações sobre a homoge neidade da região em estudo, sendo-se forçado a admitir que as pres suposiçōes feitas a esse respeito foram demasiadamente fortes. Mesmo admitindo-se que a pressuposição básica do trabalho - comportamento dissemelhante nos estratos devido a diferentes proporcionalidades entre os fatores de produção, composição das atividades,etc.possa salvar-se sem maior esforço, resta a questão se haveria possi bilidade de um tratamento mais eficiente no àmbito do modelo de pro gramação recursiva, dado que não se pode negar a diversificidade,ex tensão e complexidade da região. Está-se convencido que numa áreaon de convivem, lado a lado, atividades altamente rentáveis e especializadas, como a dos hortigranjeiros (de que é rica a região), e ati vidades extensivas e de rentabilidade cíclica, como o reflorestamen to e a pecuária de corte, não há modo de exclui-las. Aquelas, devido ao seu alto valor unitário, e estas devido principalmente ao volume de recursos exigidos pelo seu tamanho. Porém o tratamento destas atividades numa matriz tecnológica regional é algo muito difícil de se conseguir, tanto que muitas delas foram eliminadas do pre sente modelo, ainda que a expensas de um maior realismo.

De um lado a exigência de múltiplas tecnologias e,de outro, a inclusão de novas e diversas atividades, tornam o modelo de programação recursiva recomendável para regiões mais homogêneas, ou menos desenvolvidas (onde as atividades sejam extensivas e existam limites nitidos em termos de opções tecnológicas), ou em regiões me nores, a exemplo das sub-regiões e microrregiões que atendam aos re 
quisitos mínimos de homogeneidade.

Os resultados alcançados pelo presente modelo apresentam alguns aspectos de interesse já que os resultados seguiram de perto o modelo dinâmico de utilização da terra de Henderson. Grande parte de estudos complementares, no entanto, como a oferta de produtos agrícolas, e principalmente a demanda por insumos na agricultura, ambos a curto prazo, e a anälise do impacto de políticas voltadas para o setor necessitam de modificações que incluem, entre as mais importantes:

(a) Sub-regionalização, para fornecer maior homogeneidade e dar suporte às pressuposições sobre comportamento diferenciado; tal sub-regionalização pode seguir o mesmo princípio de decomposição por tạ manho de propriedade, segundo Ahn.

(b) Estimativas, no próprio local, de coeficientes técnicos usa dos para as atividades, com diferentes processos de produção, tanto mecânico como biológico; ou seja, racionalizar (no sentido de aperfeiçoarl e obter novos coeficientes de produção välidos para a sub-região em função dos processos disponíveis (funções de produção ex perimentais podem ser usadas para inclusão de novos coeficientes, desde que a sub-região esteja em condições de absorvê-los); em poucas palavras, ampliar as alternativas tecnológicas.

(c) Proceder a uma revisão completa nas disponibilidades então utilizadas, substituindo-as de modo a atender às atuais modiflca ções. 
140.

As mudanças sugeridas aqui não invalidam tentativas feitas com o presente modelo no que se refere a estudos complementa res como os desenvolvidos por ROESSING (1978) e PINAZZA (1978), por que os resultados obtidos são aproveitáveis se respeitadas as limitaçōes assinaladas. 
141.

\section{CONCLUSOES}

A conclusão principal que se pode extrair deste trabalho refere-se ao fraco desempenho do modelo na tentativa de repro duzir o padrão de evolução da produção agrícola regional.

A primeira das razões sugeridas para explicar o desempenho do modelo, e a mais importante delas, foi a falta de alter nativas tecnológicas para as atividades produtivas; isto de fato $\underline{i m}$ pediu que se procesesse às mudanças tecnológicas que são o traço essencial no processo de desenvolvimento. Com a sua ausência o mode lo não teve flexibilidade, e evoluiu na direção de ocupação de novas äreas. Daí derivou-se praticamente todo o esquema de crescimento nos diversos estratos de área; existiram outras mudanças mas, sem dúvida, esta foi determinante, enquanto as demais seguiram-1he o ras tro, com pouco significado. Tal fato é bastante comprometodor porque prende-se em demasia aos coeficientes técnicos usados (sempre re 
feridos por hectare), agravando justamente um dos maiores inconven entes da programação linear que é a proporção fixa entre os fatores de produção. Caso a disponibilidade e os tipos de terra obedecessem a um maior detalhamento isto seria minimizado, o que não ocorreu. 0 único tipo de terra restritivo foi para culturas anuais, que possuem os coeficientes mais confiáveis e são mais exigentes em recursos. E preciso considerar que desse modo não foi possível empreender mudanças significativas na proporção de fatores e, portanto, na com posição das atividades, alternativa que é dada pela troca tecnológi ca. As culturas perenes, ao que tudo indica, privilegiaram-se pelo modo como ss integraram ao modelo, enquanto pastagens e pecuária exigiam basicamente terra para pastoreio, e desembolso com os serviços de mão-de-obra, e com insumos modernos, estes últimos na forma de valores monetários, cujo controle apresentou-se mais problemático.

Para a região em estudo, devido à pulverização de atividades hortigranjeiras, e à dificuldade de incorporação de outras atividades, como reflorestamento, por exemplo, e os entraves que es tas exclusões representaram, em termos de utilização de recursos, mostra-se claramente que seriam necessárias matrizes muito complexas para uma descrição satisfatória; a extensão e diversidade regio nais constituiram-se em grandes obstáculos para a descrição de seu desenvolvimento.

Outro aspecto que comprometeu o desempenho do modelo diz respeito à competição regional. Esta praticamente não foi reali 
zada, e como consequência muitas disponibilidades - como crédito e mão-de-obra - foram pouco menos que arbitrárias, levando também a improvisações em outras: daf resultou o problema de superestimativas, agravadas principalmente pelo comportamento do fluxo monetário do sistema que se traduziu em excesso de liquidez.

Lembra-se que o curto período de tempo abrangido pelo horizonte de planejamento considerado não se presta a alterações quantivativas de vulto. As leves tendências detectadas foram alvo de discussão no capítulo 4, levando-se em conta as respectivas limitações.

Uma característica distintiva do modelo utilizado é - grande número de atividades consideradas numa ampla região desenvolvida. Especificamente, pode-se citar o tratamento original dado às culturas perenes, e o uso de um modelo de expectativa de preços para os produtos agrícolas.

Resta dizer que o estudo em questão pode ser encarado como uma primeira aproximação a receber aperfeiçoamentos, cuja contribuição maior talvez tenha sido identificar algumas das dificuldades agora encontradas. 


\section{SUMMARY}

The present study utilizes a recursive programing model to reproduce the agricultural growth pattern in the Divisão Regio nal Agrícola (DIRA) of Campinas, State of São Paulo, in the period $1970 / 71$ to $1976 / 77$. This is the research's main objective. Two minor objectives are: a discussion of the supplementary procedures to the basic model necessary for such a reproduction and the evaluation of the model's performance. The data utilized in this study wer provided by the Instituto de Economia Agrícola de São Paulo.

In the methodology chapter, the basic and the empiric models are presented in detail. The recursive programing model uses the linear programing technique to maximize a net receipt function of agricultural activities carried out in the region, subject to a number of restrictions, which reflect resource avallability; it is a 
dynamic model, in which solutions found for preceding periods are transferred to the current period through specific recursive functions. As an extension to this chapter, mention is made of the region's farms division into three strata, by area, in order to meet the assumption that each one adopts different development paths due to different resource proportions among them: it is also assumed homogeneity, , within each stratum which enables them to follow a single optimization criterion.

The results are presented as follows: (a) in terms of land use, it was shown that there was flexibility in its use for annual crops and pastures, while land for annual crops was restrictive; (b) analysis of the factors land, labor, and capital, disclosed that the highest increases in the region occurred in that order: (c) with regard to changes in the proportion of production factors, it was found that the slight trends in the period do not support any clear hypothesis in this respect: (d) insofar as financial capital use is concerned, it was found that there was excessive liquidy in the system: (e) in the case of net receipt distribution per farm, it was found that the large farm group is clearly favored; ( $f$ ) finally, confrontation was made with actual observed data for selected activities, where few adjustments proved to have an explanation, according to the test utilized.

In the conclusion chapter, it is admitted that the poor performance of the model is associated with: (a) the few techno- 
146.

logical alternatives which were permitted; $(b)$ absence of regional competition; and (c) regional diversity and extension which constitute great difficulties in simulating the agricultural production growth in the period under study. 


\section{BI8L IOGRAFIA}

AHN, C.Y., 1972. A Recursive Programming Model of Regional Agricultural Development in Southern Brazil (1960-70): An Application of Farm Size Decomposition. Columbus, The Ohio State University, 198 p. (PhD Dissertation).

ARAUJO, P.F.C. e R.L. MEYER, 1977. Agricultural Credit Policy in Brasil. In: American Journal of Agricultural Economics. Vol. 59, p. 957-961.

BRASIL. Ministério da Agricultura. Instituto Brasileiro de Coloniza ção e Reforma Agrária, 1972. Estatisticas Cadastrais.

CAMPOS, H. e L.H.O. PIVA, 1974. Dimensionamento de Amostra para Es timativa e Previsão de Safra no Estado de São Paulo. In: Agricultura em São Paulo. São Paulo. IEA, Tomo III, p. 65-88.

CHRIST, C.F., 1966. Econometrics Models and Methods, New York, John Wiley and Sons, Inc., $705 \mathrm{p}$.

DAY, R.H., 1963. Recursive Programming and Production Response. Amsterdam, North-Holland Publishing Company, 226 p. 
ENGLER, J.J.C., 1971. Alternative Enterprise Combinations under $\underline{\mathrm{Va}}$. rious Price Policies on Wheat and Cattle Farms in Southern Brasil. Columbus, The Ohio State University, 221 p. (PhD Dissertation).

GRILICHES, Z., 1970. Distributed Lags: a Survey. In: OOWLING, J.M. e F.R. GLAHE, Ed. Readings in Econometric Theory. University of Colorado, p. 151-172.

HAYAMI, Y. e V.W. RUTTAN, 1971. Agricultural Development: An International Perspective. Londres, The Johns Hopkins Press, 367 p.

HEADY, E.0. e W. CANDLER, 1969. Linear Frogramming Methods. Ames, The Iowa State University Press, 6: ed., 597 p.

HEIDHUES, T., 1966. A Recursive Programming Model of Farm Growth in Northern Germany. In: Journal of Farm Economics. Vol. 48-II, p. $668-684$.

HENOERSON, J.M., 1959. The Utilization of Agricultural Land: A Theorical and Empirical Inquiry. In: Review of Economics an Statistics. Vol. XLI, $n^{2} 3$, p. 242-260.

KMENTA, J., 1971. Elements of Econometrics. New York, The Macmillan Company, $655 \mathrm{p}$.

LEONTIEF, W.W., Coord., 1953. Studies in the Structure of the Ameri-. can Economy. New York, Oxford University Press, 286 p.

MOREIRA, R.J., 1973. Contribuição à Anālise de Investimento e Poupança na Agricultura Brasileira. Osasco, Faculdade Municipal de Ciências Econômicas e Administrativas, 209 p. (Tese de Doutoramen to). 
NERLOVE, M., 1958. Distributed Lags and Demand Analysis for Agri-. cultural and Other Commodities Agricultural Marketing Service. USDA, Agriculture Handbook, $n^{2} 141,121 \mathrm{p}$.

NERLOVE, M. e W.W. ADDISON, 1958. Statistical Estimation of Long-run Elasticities of Supply an Demand. In: Journal of Farm. Economics. Vol. XL, ne 4, p. 861-880.

PERES, F.C., 1976. Derived Demand for Credit under Conditions of Risk. Columbus, The Ohio State University, 141 p. (PhD Dissertation).

PERROCO, L.R., 1973. Análise Econômica da Produção de Bovinos de Corte, atravēs da Programação Linear. Jaboticabal, Faculdade de Medicina Veterinária e Agronomia, 167 p. (Tese de Doutoramento).

PINAZZA, L.A., 1978. Demanda Derivada por Crédito na Divisão Regional Agrícola de Campinas. Piracicaba, ESALQ/USP, 100 p. (Ois sertação de Mestrado).

ROESSING, A.C., 1978. Demanda Derivada por Fertilizantes na Divisão Regional Agrícola de Campinas. Piracicaba, ESALQ/USP, 118 p. (Dissertação de Mestrado).

SÅO PAULO. Secretaria da Agricultura. Instituto de Economia Agricola, 1971. Desenvolvimento da Agricultura Paulista.

SÅO PAULO. Secretaria da Agricultura. Instituto de Economia Agricola, 1974. Zoneamento Agrícola do Estado de São Paulo.

SÅO PAULO. Secretaria da Agricultura. Instituto de Economia Agricola, 1976, Informações Econômicas, 7-76. 
SÅO PAULO, Secretarla da Agricultura. Instituto de Economia Agricola, 1978. Prognóstico 1977/78.

SCHULTZ, T.W., 1965. A Transformação da Agricultura Tradicional. Rio de Janelro, Zahar Editores, $207 \mathrm{p}$.

SINGH, I.J., 1973. Recursive Programming Models of Agricultural Development. In: JUDGE, G.G. e T. TAKAYAMA, Ed. Studies in Ecomic Planning over Space and Time. University of Illinols, North-Holland Publishing Company, p. 394-416.

VOLLET, R.C.M.; A. VEIGA e J.J.C. ENGLER, 1974. Subsídios a uma Poliftica de Regionalização Agrícola no Estado de São Paulo. In: Agricultura em São Paulo. São Paulo, IEA, Tomo I, P. 31-69.

VON NEUMANN, J., 1945. A Model of General Economic Equilibrium. In: Review of Economics Studies, Vol. XIII, p. 1-9. 
151.

APENOICE I

DEFINIÇOES DAS VARIAVEIS:

COLUNAS E LINHAS DA MATRIZ 
E apresentada uma ünica matriz que engloba os três es tratos de ärea. As diferenças entre eles são:

1. Disponibilidades.

2. Para o estrato das pequenas propriedades estão ausentes as atividades: (a) tomate; (b) suinocultura tipo carne; (c) soja.

3. No estrato das médlas propriedades exclui-se soja para os anos de 1970/71, 1971/72 e 1972/73.

4. Para o estrato das grandes propriedades não se considera a atividade de suinocultura tipo carne.

5. Esta matriz integral é a que se encontra descrita no texto com as diferenças assinaladas. Malores detalhes para a compreensão do procedimento utilizado podem ser vistos nas secções que tratam do assunto.

Colunas

Variäveis Código Atividades

$x_{1}$ BATAGI Batata das águas $I$ : tecnologia tradicional, em hectare.

$x_{2}$ BATAG2 Batata das águas II: tecnologia moderna, em hectare.

$x_{3}$ BATSC Batata da seca, em hectares.

$x_{4}$ MALGI Algodão I: tecnologia tradicional, em hec tare.

$x_{5}$ MALG2 Algodão II: tecnologia moderna, em hecta re.

$x_{6} \quad$ CANA Cana, em hectare. 
Variávels Código

Atividades

\begin{tabular}{|c|c|c|}
\hline$x_{7}$ & MAND & Mandioca, em hectare. \\
\hline$x_{8}$ & TOMATE & Tomate, em hectare. \\
\hline$x_{9}$ & SOJA & Soja, em hectare. \\
\hline$x_{10}$ & FJAGI & $\begin{array}{l}\text { Feljão das águas I: tecnologia trad1c1o- } \\
\text { nal, em hectare. }\end{array}$ \\
\hline$x_{11}$ & FJAG2 & $\begin{array}{l}\text { Feijão das águas II: tecnologia moderna, } \\
\text { em hectare. }\end{array}$ \\
\hline$x_{12}$ & FJSCI & $\begin{array}{l}\text { Feljão da seca I: tecnologia tradicional, } \\
\text { em hectare. }\end{array}$ \\
\hline$x_{13}$ & FJSC2 & $\begin{array}{l}\text { Feijäo da seca II: tecnologia moderna, em } \\
\text { hectare. }\end{array}$ \\
\hline$x_{14}$ & MLHI & $\begin{array}{l}\text { Milho I: tecnologia tradicional, em hec- } \\
\text { tare. }\end{array}$ \\
\hline$x_{15}$ & MLH2 & Milho II: tecnologia moderna, em hectare. \\
\hline$x_{16}$ & MARROZ & Arroz, em hectare. \\
\hline$x_{17}$ & CAFINV & Investimento em café, em hectare. \\
\hline$x_{18}$ & LARIAN & Investimento em citrus, em hectare. \\
\hline$x_{19}$ & CAFIAN & Café no primeiro ano, em hectare. \\
\hline$x_{20}$ & CAF2AN & Café no segundo ano, em hectare. \\
\hline$x_{21}$ & CAF $3 A N$ & Café no terceiro ano, em hectare. \\
\hline$x_{22}$ & CAFPRD & Café em produção, em hectare. \\
\hline$x_{23}$ & LAR2AN & Citrus no segundo ano, em hectare. \\
\hline$x_{24}$ & LAR3AN & Citrus no terceiro ano, em hectare. \\
\hline$x_{25}$ & LAR4AN & Citrus no quarto ano, em hectare. \\
\hline$x_{26}$ & LARPRD & Citrus em produção, em hectare. \\
\hline$x_{27}$ & SUINB & $\begin{array}{l}\text { Suinocultura tipo banha, em unidade-ma- } \\
\text { triz. }\end{array}$ \\
\hline$x_{28}$ & SUINC & $\begin{array}{l}\text { Suinocultura tipo carne, em unidade-ma- } \\
\text { triz. }\end{array}$ \\
\hline$x_{29}$ & PECCT & $\begin{array}{l}\text { Pecuária bovina de corte, em unidade-ma- } \\
\text { triz. }\end{array}$ \\
\hline
\end{tabular}


Variäveis Código Atividades

\begin{tabular}{|c|c|c|}
\hline$x_{30}$ & PECLB & Pecuária de leite $B$, em unidade-matriz. \\
\hline$x_{31}$ & PECLC & Pecuária de leite $C$, em unidade-matriz. \\
\hline & PASART & Pasto artificial, em hectare. \\
\hline & PASNAT & Pasto natural, em hectare. \\
\hline & TFANTI & $\begin{array}{l}\text { AtIvidade de transferēncia: animal de tra } \\
\text { balho no perfodo I (Agosto a Novembro), } \\
\text { em dia-animal. }\end{array}$ \\
\hline & TFANT2 & $\begin{array}{l}\text { Atividade de transferència: animal de tra } \\
\text { balho no perfodo II (Dezembro a Março),em } \\
\text { dia-animal. }\end{array}$ \\
\hline$x_{36}$ & TFANT3 & $\begin{array}{l}\text { Atividade de transferência: animal de tra } \\
\text { balho no perído III (Abril a Julho), em } \\
\text { dia-animal. }\end{array}$ \\
\hline 37 & TFTRITR2 & $\begin{array}{l}\text { Atividade de transferèncla de terra I pa. } \\
\text { ra terra II, em hectare. }\end{array}$ \\
\hline 38 & TFTR2TR3 & $\begin{array}{l}\text { Atividade de transferència de terra II pa } \\
\text { ra terra III, em hectare. }\end{array}$ \\
\hline & FJCNS & $\begin{array}{l}\text { Consumo de feijão pelos trabalhadores fa } \\
\text { miliares, em saca de } 60 \mathrm{~kg} \text {. }\end{array}$ \\
\hline 40 & MARCNS & $\begin{array}{l}\text { Consumo de arroz pelos trabalhadores fa- } \\
\text { miliares, em saca de } 60 \mathrm{~kg} \text {. }\end{array}$ \\
\hline 41 & LCCNS & $\begin{array}{l}\text { Consumo de leite } C \text { pelos trabalhadores fa } \\
\text { miliares, em litro. }\end{array}$ \\
\hline$x$ & MINVTRT & $\begin{array}{l}\text { Investimento em trator-implementos, em } \\
\text { unidade. }\end{array}$ \\
\hline 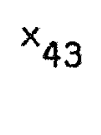 & MINVCLH & $\begin{array}{l}\text { Investimento em colhedeira de soja, em } \\
\text { unidade. }\end{array}$ \\
\hline 4 & CREDINV & Crédito para investimento, em cruzeiro. \\
\hline & CREDCT & Crédito de custeio, em cruzeiro. \\
\hline & MINSMDCR & $\begin{array}{l}\text { Compra de insumos modernos com crédito, } \\
\text { en cruzeiro. }\end{array}$ \\
\hline
\end{tabular}




\begin{tabular}{|c|c|c|}
\hline Variáveis & Código & Atividades \\
\hline$x_{47}$ & NITRONCR & $\begin{array}{l}\text { Compra de nitrogénio }(N) \text { com crédito, em } \\
\text { tonelada. }\end{array}$ \\
\hline$x_{48}$ & FOSFORCR & $\begin{array}{l}\text { Compra de } \mathrm{P}_{2} \mathrm{O}_{5} \text { (fósforo, } P \text { ) com crédito, } \\
\text { em tonelada. }\end{array}$ \\
\hline$x_{49}$ & POTASSCR & $\begin{array}{l}\text { Compra de } K_{2} O \text { (potássio, } K \text { ) com crëdito, } \\
\text { em tonelada. }\end{array}$ \\
\hline$x_{50}$ & MINSMDP & $\begin{array}{l}\text { Compra de insumos modernos com recursos } \\
\text { próprios, em cruzeiro. }\end{array}$ \\
\hline$x_{51}$ & NITRONP & $\begin{array}{l}\text { Compra de } N \text { com recursos próprios, em to } \\
\text { nelada. }\end{array}$ \\
\hline$x_{52}$ & FOSFORP & $\begin{array}{l}\text { Compra de } \mathrm{P}_{2} \mathrm{O}_{5} \text { com recursos próprios, em } \\
\text { tonelada. }\end{array}$ \\
\hline$x_{53}$ & POTASSP & $\begin{array}{l}\text { Compra de } \mathrm{K}_{2} \mathrm{O} \text { com recursos próprios, em } \\
\text { tonelada. }\end{array}$ \\
\hline$x_{54}$ & MORESP & $\begin{array}{l}\text { Compra de serviços de mão-de-obra resi- } \\
\text { dente, em dia-homem. }\end{array}$ \\
\hline$x_{55}$ & MOICONP & $\begin{array}{l}\text { Compra de serviços de mäo-de-obra contra } \\
\text { tada fora da propriedade, no período I } \\
\text { (agosto-novembro), em dia-homem. }\end{array}$ \\
\hline$x_{56}$ & MD2CONP & $\begin{array}{l}\text { Compra de serviços de mäo-de-obra contra } \\
\text { tada fora da propriedade, no perfodo II } \\
\text { (dezembro-março), em dia-homem. }\end{array}$ \\
\hline$x_{57}$ & MO3CONP & $\begin{array}{l}\text { Compra de serviços de mão-de-obra contra } \\
\text { tada fora da propriedade, no perfodo III } \\
\text { (abril-julho), em dia-homem. }\end{array}$ \\
\hline$x_{58}$ & CORRETP & Compra de corretivo, em tonelada. \\
\hline$x_{59}$ & FJCPR & $\begin{array}{l}\text { Compra de feljão para consumo, em saca de } \\
60 \mathrm{~kg} \text {. }\end{array}$ \\
\hline$x_{60}$ & MARRCPR & $\begin{array}{l}\text { Compra de arroz para consumo, em saca de } \\
60 \mathrm{~kg} \text {. }\end{array}$ \\
\hline
\end{tabular}


Variáveis cōdigo

\begin{tabular}{|c|c|c|}
\hline$x_{61}$ & MLHCPR & $\begin{array}{l}\text { Compra de milho para consumo, em saca de } \\
60 \mathrm{~kg} \text {. }\end{array}$ \\
\hline$x_{62}$ & LBVND & Vende de leite $B$, em litro. \\
\hline$x_{63}$ & LCVND & Venda de leite $C$, em litro. \\
\hline$x_{64}$ & MARRVND & Venda de arroz, em saca de $60 \mathrm{~kg}$. \\
\hline$x_{65}$ & FJVND & Venda de feijão, em saca de $60 \mathrm{~kg}$. \\
\hline$x_{66}$ & MLHVND & Venda de milho, em saca de $60 \mathrm{~kg}$. \\
\hline$x_{67}$ & CAFVND & $\begin{array}{l}\text { Venda de café, em saca de } 60 \mathrm{~kg} \text { de café } \\
\text { beneficiado. }\end{array}$ \\
\hline$x_{68}$ & LARVND & Venda de citrus, em caixa de $40 \mathrm{~kg}$. \\
\hline$x_{69}$ & MOIFAMP & $\begin{array}{l}\text { Venda de serviços de mäo-de-obra familiar } \\
\text { no perfodo I (agosto-novembro), em dia- } \\
\text {-homem. }\end{array}$ \\
\hline$x_{70}$ & MO2FAMP & $\begin{array}{l}\text { Venda de serviços de mäo-de-obra familiar } \\
\text { no perfodo II (dezembro-março), em dia- } \\
\text {-homem. }\end{array}$ \\
\hline$x_{7}$ & MO3FAMP & $\begin{array}{l}\text { Venda de serviços de mão-de-obra familiar } \\
\text { no perfodo III (abril-julho), em dia-ho- } \\
\text { mem. }\end{array}$ \\
\hline$x_{72}$ & CUSOPK & $\begin{array}{l}\text { Custo de oportunidade do capital, em cru } \\
\text { zeiro. }\end{array}$ \\
\hline
\end{tabular}




\section{Linhas}

\begin{tabular}{|c|c|c|}
\hline Variäveis & Cödigo & Restrıção \\
\hline$b_{1}$ & $\begin{array}{l}\text { TERRA1 } \\
\text { TERRA2 }\end{array}$ & $\begin{array}{l}\text { Hectares disponívels para culturas anuais. } \\
\text { Hectares disponfiveis para culturas pere- } \\
\text { nes. }\end{array}$ \\
\hline$b_{3}$ & & Hectares disponíveis para pastagens. \\
\hline$b_{4}$ & MOIFAM & $\begin{array}{l}\text { Disponibilidade de mão-de-obra familiar } \\
\text { no perfodo I (agosto-novembro), em dlas- } \\
\text {-homens. }\end{array}$ \\
\hline$b_{5}$ & MO2FAM & $\begin{array}{l}\text { Disponibilidade de mão-de-obra familiar } \\
\text { no perfodo II (dezembro-março), em dlas- } \\
\text {-homens. }\end{array}$ \\
\hline$b_{6}$ & MO3FAM & $\begin{array}{l}\text { Disponibilidade de mão-de-obra familiar } \\
\text { no perfodo III (abril-julho), em dias-ho } \\
\text { mens. }\end{array}$ \\
\hline$b_{7}$ & MORSFM & $\begin{array}{l}\text { Disponibilidade de mäo-de-obra restdente, } \\
\text { em dias-homens. }\end{array}$ \\
\hline$b_{B}$ & MOICON & $\begin{array}{l}\text { Disponibilidade de mão-de-obra contrata- } \\
\text { da no perfodo I (agosto-novembro), em } \\
\text { dias-homens.* }\end{array}$ \\
\hline $\mathrm{b}_{9}$ & MO2CON & $\begin{array}{l}\text { Disponiblildade de mão-de-obra contrata- } \\
\text { da no período II (dezembro-março), em } \\
\text { dlas-homens.* }\end{array}$ \\
\hline$b_{10}$ & MO3CON & $\begin{array}{l}\text { Disponibilidade de mäo-de-obra contrata- } \\
\text { da no períado III (abril-julho), em dias- } \\
\text {-homens.* }\end{array}$ \\
\hline$b_{11}$ & $C x$ & $\begin{array}{l}\text { Disponibilidade de caixa (recursos pró- } \\
\text { prios ou capital de giro), em cruzeiros. }\end{array}$ \\
\hline
\end{tabular}

* Trata-se de valores multo grandes, em vista da liberação loferta ilimitadal dessa categoria de mão-de-obra. 


\begin{tabular}{|c|c|c|}
\hline Varláveis & Cödigo & Restrição \\
\hline$b_{12}$ & LMCRCUS & $\begin{array}{l}\text { Disponibilidade de crédito de custeio, em } \\
\text { cruzeiros. }\end{array}$ \\
\hline$b_{13}$ & LMCRINV & $\begin{array}{l}\text { Disponibilidade de crédito para Investi- } \\
\text { mento, em cruzeiros. }\end{array}$ \\
\hline$b_{14}$ & TFCRINV & $\begin{array}{l}\text { Balanço de crédito para investimento, em } \\
\text { cruzeiros. }\end{array}$ \\
\hline$b_{15}$ & COPK & $\begin{array}{l}\text { Limite para o custo de oportunidade do } \\
\text { capital, em cruzeiros. }\end{array}$ \\
\hline$b_{16}$ & TRTI & $\begin{array}{l}\text { Disponibilidade de trator-implemento no } \\
\text { perfodo I (agosto-novembro), en dias-má- } \\
\text { quina. }\end{array}$ \\
\hline$b_{17}$ & TRT2 & $\begin{array}{l}\text { Disponibilidade de trator-1mplemento no } \\
\text { perfodo II (dezembro-março), em dias-má- } \\
\text { quina. }\end{array}$ \\
\hline$b_{18}$ & TRT3 & $\begin{array}{l}\text { Disponibilidade de trator-implemento no } \\
\text { perfodo III (abril-julho), em dias-máqui } \\
\text { na. }\end{array}$ \\
\hline$b_{19}$ & LMSPTRT & $\begin{array}{l}\text { Limite de investimento em trator-Imple- } \\
\text { mento, em nümero de unidades. }\end{array}$ \\
\hline$b_{20}$ & MANTI & $\begin{array}{l}\text { Balanço de animal de trabalho no período } \\
\text { I (agosto-novembro), em dias-animal. }\end{array}$ \\
\hline$b_{21}$ & MANT2 & $\begin{array}{l}\text { Balanço de animal de trabalho no período } \\
\text { II (dezembro-março), em dias-animal. }\end{array}$ \\
\hline$b_{22}$ & MANT3 & $\begin{array}{l}\text { Balanço de animal de trabalho no perfodo } \\
\text { III (abril-julho), em dias-animal. }\end{array}$ \\
\hline$b_{23}$ & LMSPANTI & $\begin{array}{l}\text { Disponibilidade de animal de trabaliho no } \\
\text { período I (agosto-novembro), em dias-ani } \\
\text { mal. }\end{array}$ \\
\hline $\mathrm{b}_{24}$ & LMSPANT2 & $\begin{array}{l}\text { Disponibilidade de animal de trabalho no } \\
\text { periodo II (dezembro-março), em dias-ani } \\
\text { mal. }\end{array}$ \\
\hline
\end{tabular}




\begin{tabular}{|c|c|c|}
\hline artáveis & Código & Restrição \\
\hline$b_{25}$ & LMSPANT3 & $\begin{array}{l}\text { Disponibilidade de animal de trabalho no } \\
\text { perfodo III (abril-julho), em dias-ani- } \\
\text { mal. }\end{array}$ \\
\hline$b_{26}$ & $\mathrm{CLH}$ & $\begin{array}{l}\text { Dispontbilidade de colhedetra de soja,em } \\
\text { dias-máquina. }\end{array}$ \\
\hline$b_{27}$ & LMSPCLH & $\begin{array}{l}\text { Limite de investimento em colhedeira de } \\
\text { soja, em número de unidades. }\end{array}$ \\
\hline$b_{28}$ & CORRET & Balanço de corretivo, em toneladas. \\
\hline$b_{29}$ & MNSMOD & $\begin{array}{l}\text { Balanço de insumos modernos, em cruzei- } \\
\text { ros. }\end{array}$ \\
\hline$b_{30}$ & NITRON & Balanço de nitrogênio, em toneladas. \\
\hline$b_{31}$ & FOSFOR & Balanço de $\mathrm{P}_{2} \mathrm{O}_{5}$, em toneladas. \\
\hline$b_{32}$ & POTASS & Balanço de $\mathrm{K}_{2} \mathrm{O}$, em toneladas. \\
\hline$b_{33}$ & TFARROZ & $\begin{array}{l}\text { Balanço entre produção, consumo e venda } \\
\text { de arroz, em sacas de } 60 \mathrm{~kg} \text {. }\end{array}$ \\
\hline$b_{34}$ & TFFJ & $\begin{array}{l}\text { Balanço entre produção, consumo e venda } \\
\text { de feijão, em sacas de } 60 \mathrm{~kg} \text {. }\end{array}$ \\
\hline$b_{35}$ & TFMLH & $\begin{array}{l}\text { Balanço entre produção, consumo e venda } \\
\text { de milho, em sacas de } 60 \mathrm{~kg} \text {. }\end{array}$ \\
\hline$b_{36}$ & TFLEITC & $\begin{array}{l}\text { Balanço entre produçäo, consumo e venda } \\
\text { de lelte C, em litros. }\end{array}$ \\
\hline$b_{37}$ & TFLEITB & $\begin{array}{l}\text { Balanço entre produção e venda de leite } \\
\text { B. }\end{array}$ \\
\hline$b_{38}$ & MORESI & $\begin{array}{l}\text { Mão-de-obra familiar para consumo de ar- } \\
\text { roz, em número de trabalhadores. }\end{array}$ \\
\hline$b_{39}$ & MORES2 & $\begin{array}{l}\text { Mão-de-obra familiar para consumo de fei } \\
\text { jão, em número de trabalhadores. }\end{array}$ \\
\hline$b_{40}$ & MORES3 & $\begin{array}{l}\text { Mäo-de-obra familiar para consumo de lei } \\
\text { te } C \text {, em número de trabalhadores. }\end{array}$ \\
\hline$b_{41}$ & TFCF & $\begin{array}{l}\text { Balanço entre produção e venda de café, } \\
\text { em sacas de } 60 \mathrm{~kg} \text { de café beneficiado. }\end{array}$ \\
\hline
\end{tabular}




\begin{tabular}{|c|c|c|}
\hline Variáveis & Cödigo & Restrição \\
\hline$b_{42}$ & TFLR & $\begin{array}{l}\text { Balanço entre produção e venda de citrus, } \\
\text { em caixas de } 40 \mathrm{~kg} \text {. }\end{array}$ \\
\hline$b_{43}$ & TFPASTO & $\begin{array}{l}\text { Balanço entre a capacidade de suporte das } \\
\text { pastagens e exigências em pastagens das } \\
\text { atividades pecuárias, em unidades-animal. }\end{array}$ \\
\hline$b_{44}$ & TFCFIAN & $\begin{array}{l}\text { Balanço de café (primeiro ano), en hecta } \\
\text { res. }\end{array}$ \\
\hline$b_{45}$ & TFCF2AN & $\begin{array}{l}\text { Balanço de café (segundo ano), em hecta- } \\
\text { res. }\end{array}$ \\
\hline$b_{46}$ & TFCF3AN & $\begin{array}{l}\text { Balanço de café (terceiro ano), em hecta } \\
\text { res. }\end{array}$ \\
\hline$b_{47}$ & TFCFPRD & Balanço de café em produção, em hectares. \\
\hline$b_{48}$ & TFLR2AN & $\begin{array}{l}\text { Balanço de citrus (segundo ano), em necta } \\
\text { res. }\end{array}$ \\
\hline$b_{49}$ & TFLR3AN & $\begin{array}{l}\text { Balanço de citrus (terceiro ano), em hec } \\
\text { tares. }\end{array}$ \\
\hline$b_{50}$ & TFLR4AN & $\begin{array}{l}\text { Balanço de citrus (quarto ano), em necta } \\
\text { res. }\end{array}$ \\
\hline$b_{51}$ & TFLRPRD & $\begin{array}{l}\text { Balanço de citrus em produçäo, em hecta- } \\
\text { res. }\end{array}$ \\
\hline$b_{52}$ & TRBATAGS & $\begin{array}{l}\text { Limite superior para batata das águas, em } \\
\text { hectares. }\end{array}$ \\
\hline$b_{53}$ & TRBATAGI & $\begin{array}{l}\text { Limite inferior para batata das águas, em } \\
\text { hectares. }\end{array}$ \\
\hline$b_{54}$ & TRBATSCS & $\begin{array}{l}\text { Limite superior para batata da seca, em } \\
\text { hectares. }\end{array}$ \\
\hline$b_{55}$ & TRBATSCI & 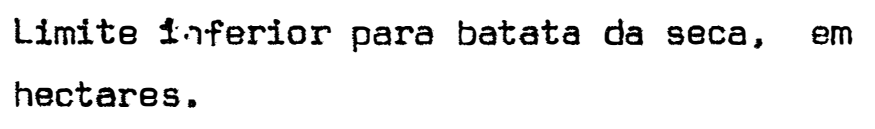 \\
\hline$b_{56}$ & TRALGS & $\begin{array}{l}\text { Limite superior para algodão, en hecta- } \\
\text { res. }\end{array}$ \\
\hline
\end{tabular}


Variáveis Código Restrição

\begin{tabular}{|c|c|c|}
\hline$b_{57}$ & TRALGI & $\begin{array}{l}\text { Limite inferior para algodão, em hecta- } \\
\text { res. }\end{array}$ \\
\hline$b_{58}$ & TRCANAS & Limite superior para cana, em hectares. \\
\hline$b_{59}$ & TRCANAI & Limite inferior para cana, em hectares. \\
\hline$b_{60}$ & TRMANDS & $\begin{array}{l}\text { Limite superior para mandioca, em hecta- } \\
\text { res. }\end{array}$ \\
\hline$b_{61}$ & TRMANDI & $\begin{array}{l}\text { Limite inferior para mandioca, em hecta- } \\
\text { res. }\end{array}$ \\
\hline$b_{62}$ & TRTOMATS & Limite superior para tomate, em hectares. \\
\hline$b_{63}$ & TRTOMATI & Limite inferior para tomate, em hectares. \\
\hline$b_{64}$ & TRSOJAS & Limite superior para soja, em hectares. \\
\hline$b_{65}$ & TRSOJAI & Limite inferior para soja, em hectares. \\
\hline$b_{66}$ & TRFJAGS & $\begin{array}{l}\text { Limite superior para feijão das äguas, em } \\
\text { hectares. }\end{array}$ \\
\hline$b_{67}$ & TRF JAGI & $\begin{array}{l}\text { Limite inferior para feijão das águas, em } \\
\text { hectares. }\end{array}$ \\
\hline$b_{68}$ & TRFJSCS & $\begin{array}{l}\text { Limite superior para feijão da seca, em } \\
\text { hectares. }\end{array}$ \\
\hline$b_{69}$ & TRFJSCI & $\begin{array}{l}\text { Limite inferior para feijão da seca, em } \\
\text { hectares. }\end{array}$ \\
\hline$b_{70}$ & TRMLHS & Limite superior para milho, em hectares. \\
\hline$b_{71}$ & TRMLHI & Limite inferior para milho, em hectares. \\
\hline$b_{72}$ & TRARRZS & Limite superior para arroz, em hectares. \\
\hline$b_{73}$ & TRARRZI & Limite inferior para arroz, em hectares. \\
\hline$b_{74}$ & TRCAFES & $\begin{array}{l}\text { Limite superior para plantio (investimen } \\
\text { to) de café, em hectares. }\end{array}$ \\
\hline$b_{75}$ & TRCAFEI & $\begin{array}{l}\text { Limite inferior para plantio (investimen } \\
\text { to) de café, em hectares. }\end{array}$ \\
\hline$b_{76}$ & TRLARJS & $\begin{array}{l}\text { Limite superior para plantio (investimen } \\
\text { tol de citrus, em hectares. }\end{array}$ \\
\hline
\end{tabular}




\begin{tabular}{|c|c|c|}
\hline Variäveis & Cödigo & Restrição \\
\hline$b_{77}$ & TRLARJI & $\begin{array}{l}\text { Limite inferior para plantio (investimen } \\
\text { to) de citrus, em hectares. }\end{array}$ \\
\hline$b_{78}$ & LMSSPSINB & $\begin{array}{l}\text { Limite superior para sulnocultura } \\
\text { banha, em unidades-animal. }\end{array}$ \\
\hline$b_{79}$ & LMIFSINB & $\begin{array}{l}\text { Limite inferior para suinovultura } \\
\text { banha, em unidades-animal. }\end{array}$ \\
\hline$b_{80}$ & LMSPSINC & $\begin{array}{l}\text { Limite superior para suinocultura } \\
\text { carne, em unidades-animal. }\end{array}$ \\
\hline$b_{81}$ & LMIFSINC & $\begin{array}{l}\text { Limite inferior para suinocultura tipo } \\
\text { carne, em unidades-animal. }\end{array}$ \\
\hline$b_{82}$ & LMSPCT & $\begin{array}{l}\text { Limite superior para pecuárla bovina de } \\
\text { corte, em unidades-animal. }\end{array}$ \\
\hline$b_{83}$ & LMIFCT & $\begin{array}{l}\text { Limite Inferior para pecuäria bovina de } \\
\text { corte, em unidades-animal. }\end{array}$ \\
\hline$b_{84}$ & LMSPLTB & $\begin{array}{l}\text { Limite superior para pecuária de leite } B \text {, } \\
\text { em número de vacas em lactação. }\end{array}$ \\
\hline$b_{85}$ & LMIFLTB & $\begin{array}{l}\text { Limite inferior para pecuária de leite } B \text {, } \\
\text { em nümero de vacas em lactação. }\end{array}$ \\
\hline$b_{86}$ & LMSPLTC & $\begin{array}{l}\text { Limite superior para pecuária de leite } C \text {, } \\
\text { em número de vacas em lactação. }\end{array}$ \\
\hline$b_{B 7}$ & LMIFLTC & $\begin{array}{l}\text { Limite inferior para pecuäria de leite } C \text {, } \\
\text { em nümero de vacas em lactação. }\end{array}$ \\
\hline$b_{88}$ & TRPTARTS & $\begin{array}{l}\text { Limite superior para pasto artificial, em } \\
\text { hectares. }\end{array}$ \\
\hline$b_{89}$ & TRPTARTI & $\begin{array}{l}\text { Limite inferior para pasto artificial, em } \\
\text { hectares. }\end{array}$ \\
\hline$b_{90}$ & TRPTNATS & $\begin{array}{l}\text { Limite superior para pasto natural, em hec } \\
\text { tares. }\end{array}$ \\
\hline$b_{91}$ & TRPTNATI & $\begin{array}{l}\text { Limite inferior para pasto natural, em hec } \\
\text { tares. }\end{array}$ \\
\hline
\end{tabular}


163.

APENDICE 2

MATRIZ DOS COEFICIENTES TECNICOS PARA O ANO INICIAL (1970/71), E A RESPECTIVA FUNÇÃO-OBJETIVO (RECE ITA) 
Os coeficientes técnicos usados na matriz, com exceção de poucos, foram retirados de "Informações Econômicas", do IEA, de julho de 1976. Os coeficientes na forma de valores monetärios so freram deflação através de Indices específicos para cada um dos itens de que eles se compunham, Indices que são publicados mensalmen te na mesma fante citada acima.

\section{COLUMNSS}

\begin{tabular}{|c|c|}
\hline $\begin{array}{l}M A L G 1 \\
M A L G 1 \\
M A L G 1\end{array}$ & $\begin{array}{l}\text { RECEITA } \\
\text { RETORNO } \\
\text { MOPFAM }\end{array}$ \\
\hline $\begin{array}{l}M A \perp G 1 \\
M A \backslash G 1\end{array}$ & $\begin{array}{l}\text { NITRON } \\
\text { POTASS }\end{array}$ \\
\hline MALGL & TRT 1. \\
\hline MALGI & MNSMOO \\
\hline MALG 1 & TRALGI \\
\hline $\begin{array}{l}\text { MALGZ } \\
\text { MALG? } \\
\text { MALG2 }\end{array}$ & $\begin{array}{l}\text { RECE ITA } \\
\text { RETORNO } \\
\text { MORFAM }\end{array}$ \\
\hline$M A L G 2$ & NITRON \\
\hline$M A L G ?$ & POTASS \\
\hline$M A L G 2$ & TRTI \\
\hline$M A \perp G 2$ & MNSMOO \\
\hline$M A L G$ ? & TRALGS \\
\hline PATAGI & RECEITA \\
\hline BATAG1 & RETORND \\
\hline BATAG1 & MO2FAM \\
\hline EA A I & FOSFOR \\
\hline BATAGL & MNSMOD \\
\hline PATAG 1 & MANT 2 \\
\hline QATAG 1 & TPBATAGS \\
\hline PATAG2 & RECEITA \\
\hline BATAG2 & PETORNO \\
\hline BATAG2 & MOZFAM \\
\hline PATAG2 & FOSFOR \\
\hline BATAGZ & CORRET \\
\hline EATAG? & TP.T 1 \\
\hline RATAG2 & MANT? \\
\hline RATAGZ & TRBATAGS \\
\hline RATSC & REECEITA \\
\hline BATSC & RETORNO \\
\hline
\end{tabular}

$\begin{array}{cl}1173.61000 & \text { TERRA1 } \\ 1224.17000 & \text { MOIFAM } \\ 12.51000 & \text { MO3FAM } \\ 0.04780 & \text { FOSFOR } \\ 0.06900 & \text { COPRET } \\ 1.40000 & \text { TRT2 } \\ 166.45000 & \text { MANT2 } \\ 1.00000 & \text { TRALGS } \\ 1270.89000 & \text { TERRA1 } \\ 1328.12000 & \text { MO1FAM } \\ 8.92000 & \text { MO3FAM } \\ 0.04780 & \text { FOSFOR } \\ 0.06900 & \text { CORRET } \\ 1.40000 & \text { TPT2 } \\ 166.45000 & \text { TRALGI } \\ 1.00000 & \\ 2585.88000 & \text { TERRA1 } \\ 2581.12000 & \text { MOIFAM } \\ 24.54000 & \text { NITRON } \\ 0.20300 & \text { POTASS } \\ 1199.96000 & \text { MANTI } \\ 5.46000 & \text { TRBATAGI } \\ 1.00000 & \\ 2608.65000 & \text { TERRAI } \\ 2603.73000 & \text { MO1FAM } \\ 24.54000 & \text { NITRON } \\ 0.23520 & \text { POTASS } \\ 0.55000 & \text { MNSMOD } \\ 1.24000 & \text { MANTI } \\ 5.46000 & \text { TREATAGI } \\ 1.00000 & \\ 2379.96000 & \text { TERRA1 } \\ 1970.74000 & \text { MO2FAM } \\ & \end{array}$

1.00000

1.65000

36.67000

0.06900

1.26000

0.19000

$5 \cdot 14000$

1.00000

1.00000

1.65000

36.67000

0.06900

1.26000

0.69000

1.00000

1.00000

46.4000

0.05800

0.11600

$\$ 3 \div 1000$

1.00000

.00000

43.58000

0.06720

0.13440

1245.98000

7.66000

2.00000

1.00000

71.82000 


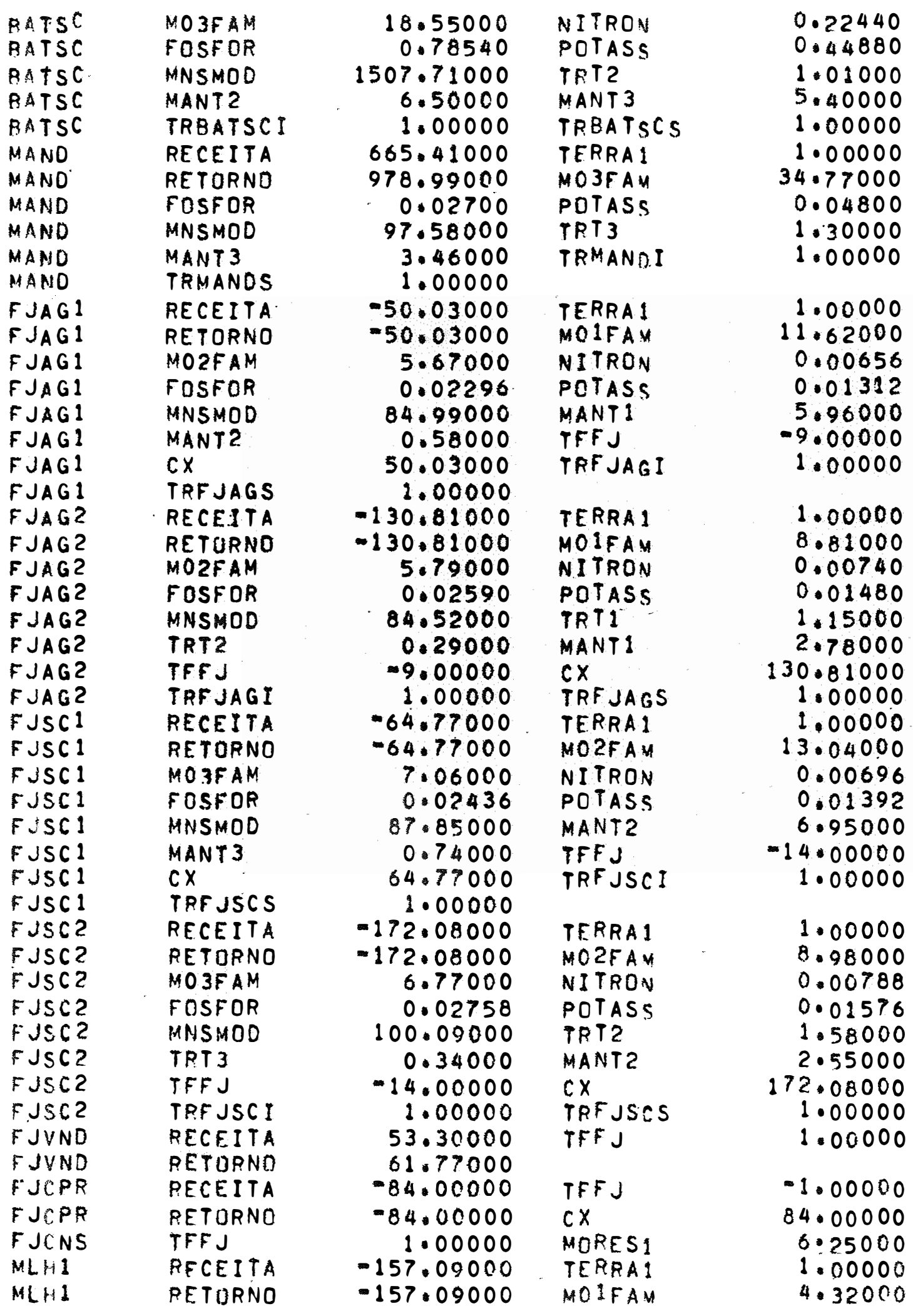




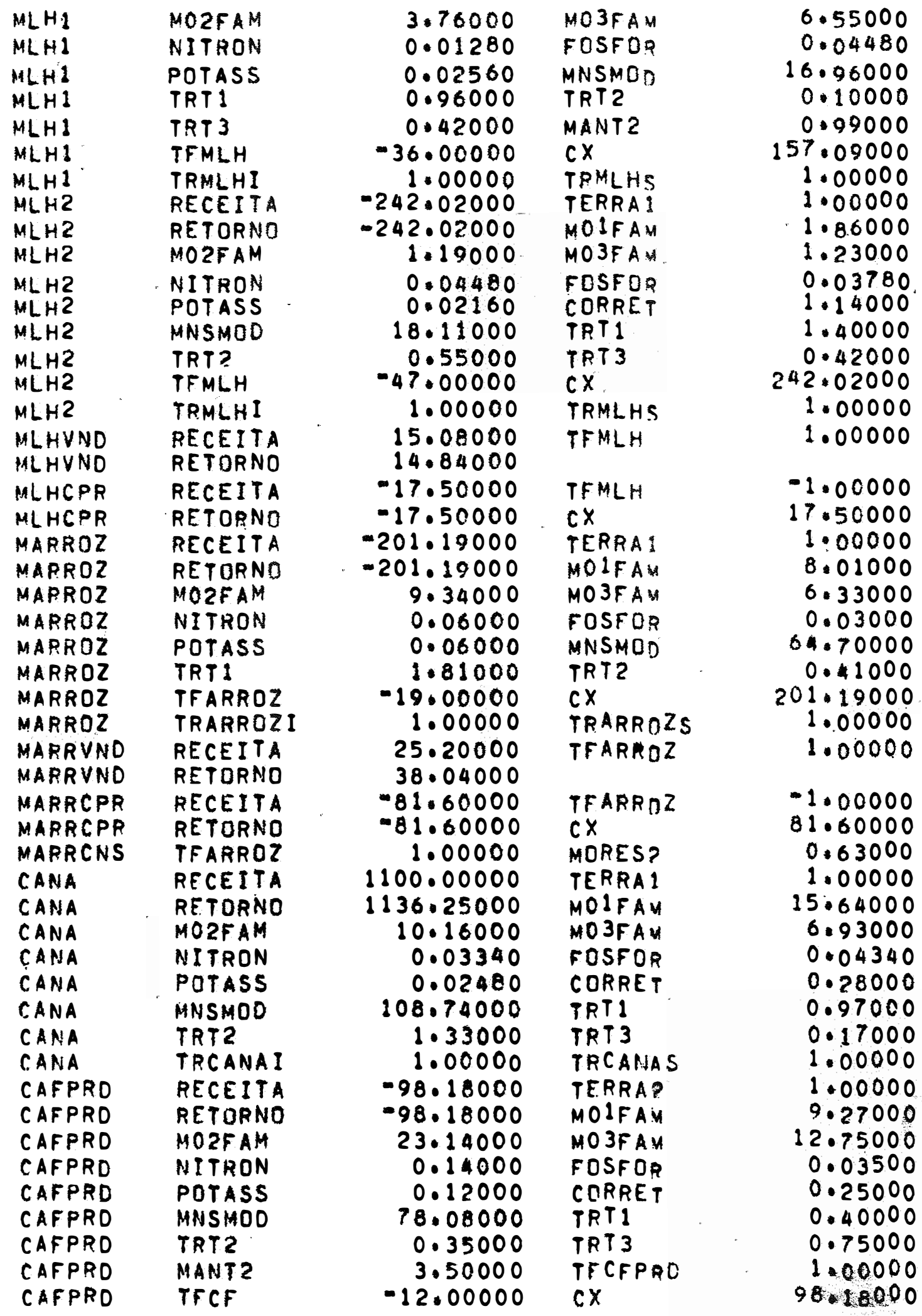




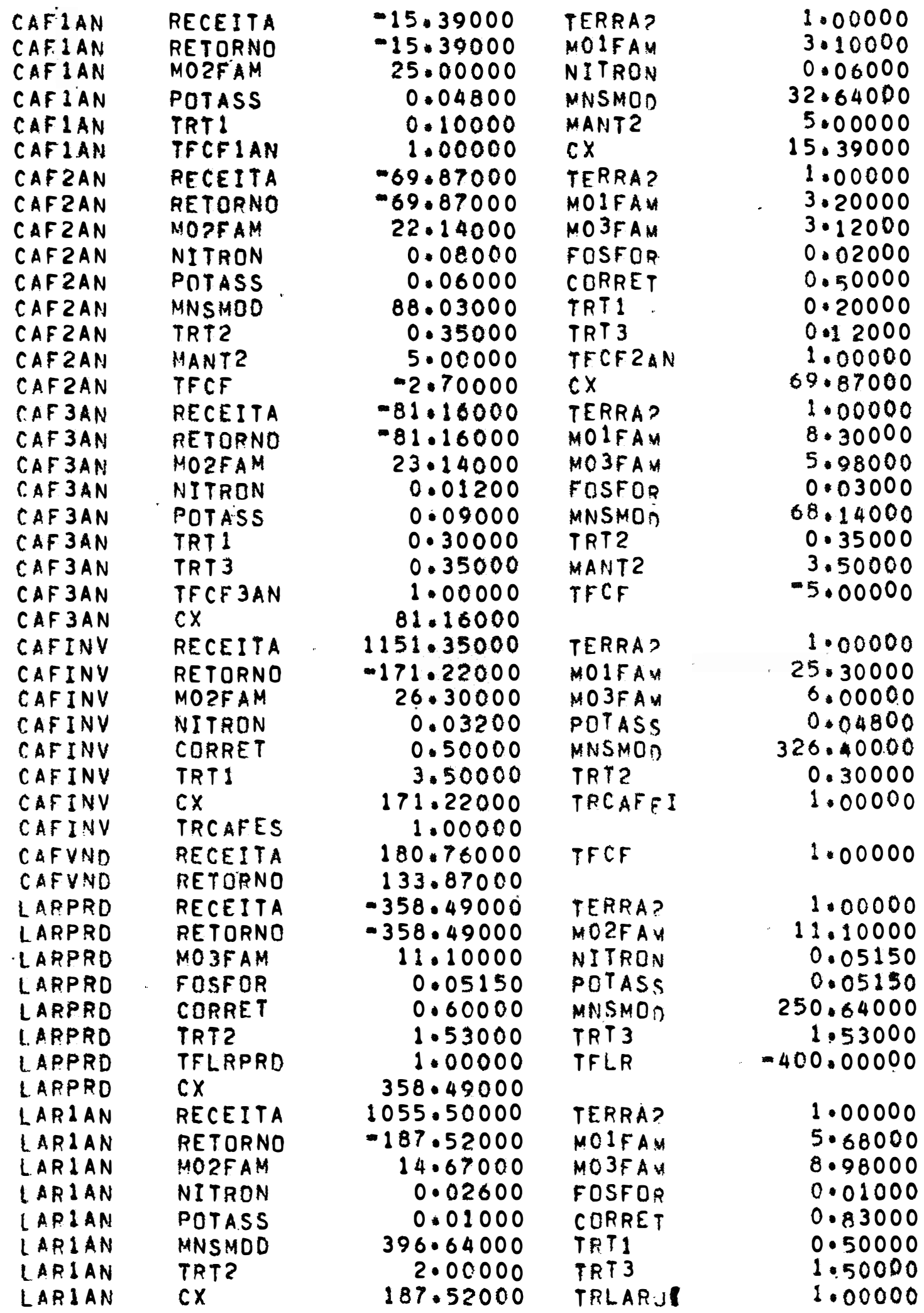




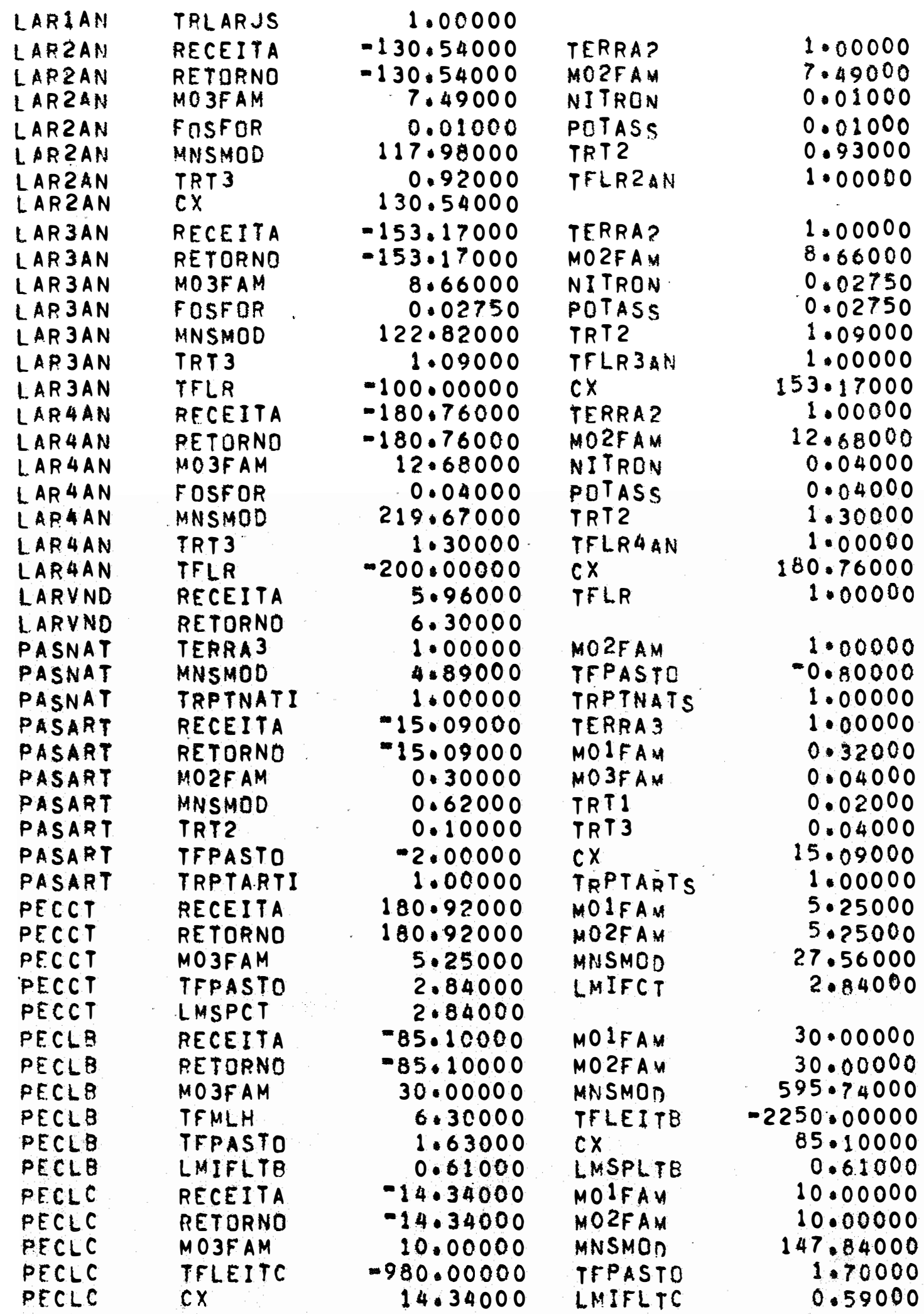




\begin{tabular}{|c|c|c|c|c|}
\hline $\begin{array}{l}\text { PECLC } \\
\text { LBVND } \\
\text { LBVND } \\
\text { LCVND } \\
\text { LCVND }\end{array}$ & $\begin{array}{l}\text { LMSPLTC } \\
\text { RECEITA } \\
\text { RETORNO } \\
\text { RECEITA } \\
\text { RETORNO }\end{array}$ & $\begin{array}{l}0.59000 \\
0.57000 \\
0.57000 \\
0.39000 \\
0.39000\end{array}$ & $\begin{array}{l}\text { TFLEITE } \\
C X \\
\text { TFLEITC } \\
C X\end{array}$ & $\begin{array}{r}1.00000 \\
-0.28000 \\
1.00000 \\
-0.19000\end{array}$ \\
\hline $\begin{array}{l}\text { LCCNS } \\
\text { SUINB } \\
\text { SUINB } \\
\text { SUINB } \\
\text { SUINB }\end{array}$ & $\begin{array}{l}\text { TFLEITC } \\
\text { RECEITA } \\
\text { RETORNO } \\
\text { MOSFAM } \\
\text { TFMLH }\end{array}$ & $\begin{array}{r}1.00000 \\
919.18000 \\
919.18000 \\
5.00000 \\
7.50000\end{array}$ & $\begin{array}{l}\text { MORES } 3 \\
\text { MOIFAM } \\
\text { MO2FAM } \\
\text { MNSMOD } \\
\text { LMIFS INB }\end{array}$ & $\begin{array}{r}0.01400 \\
5.00000 \\
5.00000 \\
18.17000 \\
7.10000\end{array}$ \\
\hline $\begin{array}{l}\text { SUINB } \\
\text { TFANT1 } \\
\text { TFANTI }\end{array}$ & $\begin{array}{l}\text { LMSPSINB } \\
\text { MANTI } \\
\text { TFMLH }\end{array}$ & $\begin{array}{r}7.10000 \\
=1.00000 \\
0.03000\end{array}$ & LMSPANTI & 1.00000 \\
\hline $\begin{array}{l}\text { TFANT? } \\
\text { TFANT2 }\end{array}$ & $\begin{array}{l}\text { MANT2 } \\
\text { TFMLH }\end{array}$ & $\begin{array}{r}-1.00000 \\
0.03000\end{array}$ & LMSPANT? & 1.00000 \\
\hline $\begin{array}{l}\text { TFANT3 } \\
\text { TFANT } 3\end{array}$ & $\begin{array}{l}\text { MANT } 3 \\
\text { TFMLH }\end{array}$ & $\begin{array}{r}-1.00000 \\
0.03000\end{array}$ & LMSPANT 3 & 1.00000 \\
\hline $\begin{array}{l}\text { MORESP } \\
\text { MORESP } \\
\text { MORESP } \\
\text { MORESP }\end{array}$ & $\begin{array}{l}\text { RECEITA } \\
\text { RETORNO } \\
\text { MO BFAM } \\
\text { CX }\end{array}$ & $\begin{array}{r}-17.77000 \\
=17.77000 \\
=1.00000 \\
17.77000\end{array}$ & $\begin{array}{l}\text { MO1FAM } \\
\text { MOZFAM } \\
\text { MORSF }\end{array}$ & $\begin{array}{r}-1.00000 \\
-1.00000 \\
1.00000\end{array}$ \\
\hline $\begin{array}{l}\text { MO1CONP } \\
\text { MO1CONP } \\
\text { MOICONP }\end{array}$ & $\begin{array}{l}\text { RECEITA } \\
\text { RETORNO } \\
C X\end{array}$ & $\begin{array}{r}-5.88000 \\
-5.88000 \\
5.88000\end{array}$ & $\begin{array}{l}\text { MOIFAM } \\
\text { MOICDN }\end{array}$ & $\begin{array}{r}-1.00000 \\
1.00000\end{array}$ \\
\hline $\begin{array}{l}\text { M02CONP } \\
\text { MO2CONP } \\
\text { MO2CONP }\end{array}$ & $\begin{array}{l}\text { RECEITA } \\
\text { RETDRNO } \\
\text { CX }\end{array}$ & $\begin{array}{r}-6.58000 \\
-6.58000 \\
6.58000\end{array}$ & $\begin{array}{l}\text { MO2FAM } \\
\text { MO2CON }\end{array}$ & $\begin{array}{l}-1.00000 \\
1.00000\end{array}$ \\
\hline MO3CONP & RECEITA & -7.04000 & MO3FAM & -1.00000 \\
\hline $\begin{array}{l}\text { MO3CONP } \\
\text { MOZCONP }\end{array}$ & $\begin{array}{l}\text { RETORNO } \\
C X\end{array}$ & $\begin{array}{r}-7.04000 \\
7.04000\end{array}$ & MO3CON & 1.00000 \\
\hline $\begin{array}{l}\text { MO1FAMP } \\
\text { MO1FAMP }\end{array}$ & $\begin{array}{l}\text { RECEITA } \\
\text { RETORNO }\end{array}$ & $\begin{array}{l}5.65000 \\
5.65000\end{array}$ & $\begin{array}{l}\text { MOIFAM } \\
C X\end{array}$ & $\begin{array}{r}1.00000 \\
-2.82000\end{array}$ \\
\hline $\begin{array}{l}\text { MO2F AMP } \\
M 02 F A M P \\
\text { MO }\end{array}$ & $\begin{array}{l}\text { RECEITA } \\
\text { RETORNO } \\
\text { RECEITA }\end{array}$ & $\begin{array}{l}5.68000 \\
5.68000 \\
6.44000\end{array}$ & $\begin{array}{l}\text { MOZFAM } \\
C X \\
\text { MOZFAM }\end{array}$ & $\begin{array}{r}1.00000 \\
=2.84000 \\
1.00000\end{array}$ \\
\hline $\begin{array}{l}\text { MOZFAMP } \\
\text { NITRONP }\end{array}$ & $\begin{array}{l}\text { RETORNO } \\
\text { RECEITA }\end{array}$ & $\begin{array}{r}6.44000 \\
-268.92000\end{array}$ & $\begin{array}{l}\text { CX } \\
\text { NITRON }\end{array}$ & $\begin{array}{l}-3.22000 \\
-1.00000\end{array}$ \\
\hline $\begin{array}{l}\text { NITRONP } \\
\text { NITRONCR. }\end{array}$ & $\begin{array}{l}\text { RETORNO } \\
\text { RECEITA }\end{array}$ & $\begin{array}{l}-268.92000 \\
-268.92000\end{array}$ & $\begin{array}{l}C X \\
\text { NITRON }\end{array}$ & $\begin{array}{r}268.92000 \\
-1.00000\end{array}$ \\
\hline $\begin{array}{l}\text { NITRONCR } \\
\text { FOSFORP } \\
\text { FOSFORP }\end{array}$ & $\begin{array}{l}\text { RETORNO } \\
\text { RECEITA } \\
\text { RETORNO }\end{array}$ & $\begin{array}{l}-268.92000 \\
-278.81000 \\
-278.81000\end{array}$ & $\begin{array}{l}\text { LACRCUS } \\
\text { FOSFOR } \\
\text { CX }\end{array}$ & $\begin{array}{r}268.92000 \\
-1.00000 \\
278.81000\end{array}$ \\
\hline $\begin{array}{l}\text { FOSFORCR } \\
\text { FOSF ORCR }\end{array}$ & $\begin{array}{l}\text { RECEITA } \\
\text { RETDRNO }\end{array}$ & $\begin{array}{l}-278.81000 \\
-278.81000\end{array}$ & $\begin{array}{l}\text { FOSFOR } \\
\text { LACRCUS }\end{array}$ & $\begin{array}{r}1.00000 \\
278.81 .000\end{array}$ \\
\hline $\begin{array}{l}\text { POTASSP } \\
\text { POTASSP }\end{array}$ & $\begin{array}{l}\text { RECEITA } \\
\text { RETORNO }\end{array}$ & $\begin{array}{l}-280.21000 \\
-280.21000\end{array}$ & $\begin{array}{l}\text { PDTASS } \\
\text { CX }\end{array}$ & $\begin{array}{r}-1.00000 \\
280 \cdot 21000\end{array}$ \\
\hline $\begin{array}{l}\text { POTASSCR } \\
\text { POTASSCR } \\
\text { COPRETP }\end{array}$ & $\begin{array}{l}\text { RECEITA } \\
\text { RETORNO } \\
\text { RECEITA }\end{array}$ & $\begin{array}{r}280.21000 \\
-280.21000 \\
-39.78000\end{array}$ & $\begin{array}{l}\text { POTASS } \\
\text { LMCRCUS } \\
\text { CORRET }\end{array}$ & $\begin{array}{r}-1.00000 \\
280.21000 \\
-1.00000\end{array}$ \\
\hline COPRETP & RETOANO & -39.78000 & $c x$ & 39.78000 \\
\hline
\end{tabular}




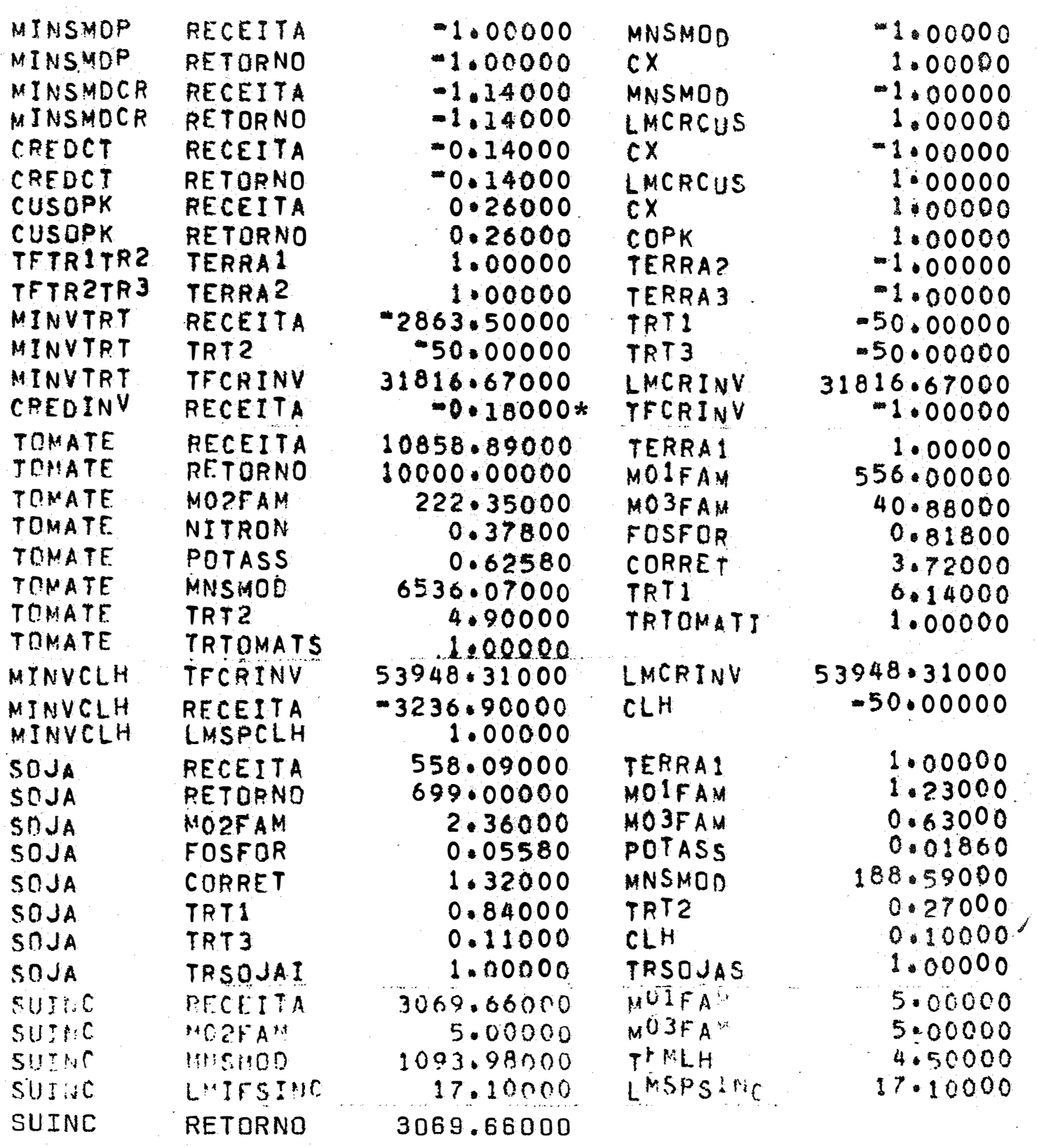

* Para o grupo das pequenas e médlas propriedades, o valor seria -0,15. 
171.

APENDICE 3

RESULTADOS DO MODELO PARA AS ATIVIDADES PRODUTIVAS, E ALGUNS DADOS REAIS OBSERVADOS. 
$1970 / 71$

\begin{tabular}{|c|c|c|c|c|c|c|}
\hline \multirow{3}{*}{$\begin{array}{c}\text { ATIVIDADES } \\
\text { Algodão (hectares) }\end{array}$} & \multicolumn{6}{|c|}{ ESTRATOS } \\
\hline & \multicolumn{2}{|c|}{$\begin{array}{l}\text { Pequeno } \\
\text { Modelo Observadt }\end{array}$} & \multicolumn{2}{|c|}{ Méd1o } & \multicolumn{2}{|c|}{$\begin{array}{c}\text { Grande } \\
\text { lo Mode lo Observado }\end{array}$} \\
\hline & 2.934 & 3.793 & 38.957 & 49.945 & 21.964 & 18.895 \\
\hline Cana (hectares) & 2.663 & 1.973 & 39.503 & 71.881 & 103.370 & 204.445 \\
\hline Milho (hectares) & 7.727 & 9.091 & 54.894 & 66.137 & 54.841 & 68.551 \\
\hline Arroz (hectares) & 3.082 & 3.852 & 20.350 & 21.421 & 21.523 & 19.255 \\
\hline $\begin{array}{l}\text { Soja (hectares) } \\
\text { Batata das águas }\end{array}$ & - & - & - & - & 2.570 & 2.856 \\
\hline $\begin{array}{l}\text { (hectares) } \\
\text { Batata da seca }\end{array}$ & 1.831 & - & 1.708 & - & 3.558 & - \\
\hline (hectares) & 685 & - & 2.160 & - & 1.317 & - \\
\hline $\begin{array}{l}\text { Mandioca (hoctares) } \\
\text { Feijäo das äguas }\end{array}$ & 263 & - & 12.535 & - & 3.598 & - \\
\hline $\begin{array}{l}\text { (hectares) } \\
\text { Feljäo da seca }\end{array}$ & 375 & 172 & 2.664 & 3.552 & 3.648 & 3.173 \\
\hline (hectares) & 272 & 302 & 3.898 & 4.990 & 5.323 & 4.436 \\
\hline $\begin{array}{l}\text { Tomate (hectares) } \\
\text { Café ärea total }\end{array}$ & - & - & 721 & - & 747 & - \\
\hline $\begin{array}{l}\text { (hectares) } \\
\text { Laranja (citrus) ärea }\end{array}$ & 3.554 & 3.234 & 12.760 & 12.760 & 36.503 & 37.465 \\
\hline $\begin{array}{l}\text { total em hectares } \\
\text { Pecuäria bovina de cor }\end{array}$ & 6.805 & 4.060 & 43.748 & 28.836 & 29.972 & 17.535 \\
\hline $\begin{array}{l}\text { te (unidades-animal) } \\
\text { Pecuária de leite } B\end{array}$ & 4.500 & - & 76.500 & - & 151.200 & - \\
\hline (unidades-matriz) & 267 & - & 4.890 & - & 9.981 & - \\
\hline $\begin{array}{l}\text { Pecuária de leite } c \\
\text { (vacas em lactaçăo) } \\
\text { Suinocultura tipo banha }\end{array}$ & 3.686 & - & 32.935 & - & 102.581 & - \\
\hline (unidades-animal) & 33.047 & - & 71.572 & - & 63.398 & - \\
\hline $\begin{array}{l}\text { Suinocultura tipo carne } \\
\text { (unidades-animal) } \\
\text { Pasto artificial }\end{array}$ & - & - & 17.890 & - & - & - \\
\hline $\begin{array}{r}\text { (hectares) } \\
\text { Pasto natural }\end{array}$ & 3.990 & - & 64.545 & - & 202.370 & - \\
\hline (hectares) & 9.469 & - & 150.331 & - & 348.314 & - \\
\hline
\end{tabular}

FONTE: Resultados do Modelo a Dados do IEA. 
ESTRATOS

ATIVIDADES

Pequeno Médio

Grande

Modelo Observado Modelo Observado Modelo Observado

\begin{tabular}{|c|c|c|c|c|c|c|}
\hline Algodão (hectares) & 3.667 & 5.648 & 35.184 & 44.385 & 26.828 & 31.378 \\
\hline Cana (hectares) & 3.595 & 2.552 & 56.126 & 66.572 & 129.909 & 202.186 \\
\hline Milho (hectares) & 6.649 & 5.344 & 45.562 & 54.777 & 43.873 & 72.466 \\
\hline Arroz (hectares) & 2.466 & 993 & 19.333 & 17.684 & 20.447 & 21.523 \\
\hline Soja (hectares) & - & - & - & - & 3.341 & 4.600 \\
\hline $\begin{array}{l}\text { Batata das äguas } \\
\text { (hectares) }\end{array}$ & 1.831 & - & 1.708 & - & 3.558 & - \\
\hline Batata da seca & & & & & & \\
\hline (hectares) & 548 & - & 1.728 & - & 1.054 & - \\
\hline $\begin{array}{l}\text { Mandioca (hectares) } \\
\text { FeIfäo das äguas }\end{array}$ & 263 & - & 12.535 & - & 3.598 & - \\
\hline $\begin{array}{l}\text { (hectares) } \\
\text { Feijäo da seca }\end{array}$ & 487 & 1.080 & 3.197 & 4.147 & 4.185 & 1.966 \\
\hline (hectares) & 326 & 296 & 3.036 & 3.906 & 4.178 & 5.998 \\
\hline $\begin{array}{l}\text { Tomate (hectares) } \\
\text { Café ärea total }\end{array}$ & - & - & 649 & - & 672 & - \\
\hline $\begin{array}{l}\text { (hectares) } \\
\text { Laranja (citrus) }\end{array}$ & 3.826 & 3.421 & 24.742 & 13.516 & 43.199 & 36.460 \\
\hline $\begin{array}{l}\text { área total em. hectares } \\
\text { Pecuária bovina de cor }\end{array}$ & 9.137 & 2.612 & 52.186 & 28.002 & 35.822 & 19.597 \\
\hline $\begin{array}{l}\text { te (unidades-animal) } \\
\text { Pecuária de leite B }\end{array}$ & 5.040 & - & 78.718 & - & 158.760 & - \\
\hline (unidades-matriz) & 174 & - & 4.255 & - & 7.785 & - \\
\hline $\begin{array}{l}\text { Pecuäria de leite } C \\
\text { (vacas em lactação) } \\
\text { Suinocultura tipo banha }\end{array}$ & 3.806 & - & 18.773 & - & 80.013 & - \\
\hline $\begin{array}{l}\text { (unidades-animal) } \\
\text { SuInocultura tipo carne }\end{array}$ & 33.047 & - & 78.717 & - & 63.398 & - \\
\hline $\begin{array}{l}\text { (unidades-animal) } \\
\text { Pasto artificial }\end{array}$ & - & - & 25.519 & - & - & - \\
\hline $\begin{array}{l}\text { (hectares) } \\
\text { Pasto natural }\end{array}$ & 3.990 & - & 56.154 & - & 151.777 & - \\
\hline (hectares) & 0.522 & - & 145.821 & - & 344.831 & - \\
\hline
\end{tabular}

FONTE: Resultados do Modelo a Dados do IEA. 
$1972 / 73$

\begin{tabular}{|c|c|c|c|c|c|c|}
\hline \multirow{2}{*}{ ATIVIDADES } & \multicolumn{6}{|c|}{ ESTRATOS } \\
\hline & \multicolumn{2}{|c|}{$\begin{array}{c}\text { Pequeno } \\
\text { Modelo Observado }\end{array}$} & \multicolumn{2}{|c|}{ Médio } & \multicolumn{2}{|c|}{$\begin{array}{l}\text { Grande } \\
\text { lo Observad }\end{array}$} \\
\hline Algodão (hectares) & 4.584 & 6.124 & 43.276 & 52.935 & 37.615 & 16.541 \\
\hline Cana (hectares) & 4.433 & 2.349 & 63.948 & 62.086 & 127.484 & 201.963 \\
\hline Milho (hectares) & 5.652 & 4.142 & 53.307 & 50.254 & 35.098 & 65.803 \\
\hline Arroz (hectares) & 1.973 & 368 & 18.366 & 17.887 & 19.425 & 22.645 \\
\hline $\begin{array}{l}\text { Soja (hectares) } \\
\text { Batata das äguas }\end{array}$ & - & - & - & - & 3.566 & 4.600 \\
\hline $\begin{array}{l}\text { (hectares) } \\
\text { Batata da seca }\end{array}$ & 1.831 & - & 1.708 & - & 3.558 & - \\
\hline (hectares) & 438 & - & 1.382 & - & 843 & - \\
\hline $\begin{array}{l}\text { Mand1oca (hectares) } \\
\text { Feljão das äguas }\end{array}$ & 263 & - & 12.535 & - & 3.598 & - \\
\hline $\begin{array}{l}\text { (hectares) } \\
\text { Feijäo da seca }\end{array}$ & 365 & 298 & 3.836 & 4.974 & 4.813 & 6.628 \\
\hline (hectares) & 293 & 397 & 3.370 & 5.539 & 5.014 & 2.564 \\
\hline $\begin{array}{l}\text { Tomate (hectares) } \\
\text { Café ärea total }\end{array}$ & - & - & 714 & - & 739 & - \\
\hline $\begin{array}{l}\text { (hectares) } \\
\text { Laranja (citrus) }\end{array}$ & 4.371 & 2.072 & 16.124 & 16.636 & 49.159 & 43.371 \\
\hline $\begin{array}{l}\text { área total em hectares } \\
\text { Pecuárla bovina de cor }\end{array}$ & 11.979 & 4.047 & 60.842 & 36.129 & 40.644 & 18.475 \\
\hline $\begin{array}{l}\text { te (unidades-animal) } \\
\text { Pecuária de leite } B\end{array}$ & 5.040 & - & 81.000 & - & 166.698 & - \\
\hline $\begin{array}{l}\text { (unidades-matriz) } \\
\text { Pecuária de leite C }\end{array}$ & 113 & - & 3.700 & - & 6.072 & - \\
\hline $\begin{array}{l}\text { (vacas em lactação) } \\
\text { Suinocultura tıpo banha }\end{array}$ & 3.559 & - & 24.717 & - & 104.817 & - \\
\hline $\begin{array}{l}\text { (unidades-animal) } \\
\text { Sulnocultura tipo carne }\end{array}$ & 33.047 & - & 86.588 & - & 63.398 & - \\
\hline $\begin{array}{l}\text { (unidades-animal) } \\
\text { Pasto artificial }\end{array}$ & - & - & 32.470 & - & - & - \\
\hline $\begin{array}{l}\text { (hectares) } \\
\text { Pasto natural }\end{array}$ & 3.990 & - & 48.854 & - & 113.733 & - \\
\hline (hectares) & 9.374 & - & 141.446 & - & 341.382 & - \\
\hline
\end{tabular}

FONTE: Resultados do Modelo a Dados do IEA. 
1973/74

\begin{tabular}{|c|c|c|c|c|c|c|}
\hline \multirow[b]{2}{*}{ ATIVIOADES } & \multicolumn{6}{|c|}{ ESTRATOS } \\
\hline & \multicolumn{2}{|c|}{$\begin{array}{c}\text { Pequeno } \\
\text { Modelo Observado }\end{array}$} & \multicolumn{2}{|c|}{$\begin{array}{l}\text { Mëdio } \\
\text { o Observad }\end{array}$} & \multicolumn{2}{|c|}{$\begin{array}{l}\text { Grande } \\
\text { lo Observado }\end{array}$} \\
\hline Algodão (hectares) & 4.126 & 2.142 & 40.385 & 53.325 & 33.853 & 54.935 \\
\hline Cana (hectares) & 5.984 & 7.026 & 72.900 & 70.623 & 137.014 & 222.354 \\
\hline Milho (hectares) & 4.804 & 7.326 & 60.022 & 53.571 & 45.627 & 49.603 \\
\hline Arroz (hectares) & 1.578 & 2.180 & 17.448 & 17.825 & 18.454 & 18.989 \\
\hline $\begin{array}{l}\text { Soja (hectares) } \\
\text { Batata das äguas }\end{array}$ & - & - & 2.784 & 1.856 & 4.636 & 9.843 \\
\hline $\begin{array}{l}\text { (hectares) } \\
\text { Batata da seca }\end{array}$ & 1.831 & - & 1.708 & - & 3.558 & - \\
\hline (hectares) & 460 & - & 1.382 & - & 843 & - \\
\hline $\begin{array}{l}\text { Mandioca (hectares) } \\
\text { Feijão das äguas }\end{array}$ & 223 & - & 12.535 & - & 3.598 & - \\
\hline $\begin{array}{l}\text { (hectares) } \\
\text { Feijäo da seca }\end{array}$ & 474 & 730 & 4.603 & 9.334 & 5.535 & 4.647 \\
\hline (hectares) & 352 & 117 & 3.741 & 4.869 & 6.017 & 4.014 \\
\hline $\begin{array}{l}\text { Tomate (hectares) } \\
\text { Cafë área total }\end{array}$ & - & - & 785 & - & 813 & - \\
\hline $\begin{array}{l}\text { (hectares) } \\
\text { Laranja (citrus) }\end{array}$ & 5.377 & 4.223 & 22.327 & 24.219 & 56.638 & 33.658 \\
\hline $\begin{array}{l}\text { área total em hectares } \\
\text { Pecuärla bovina de cor }\end{array}$ & 13.592 & 9.085 & 69.671 & 40.080 & 41.709 & 34.152 \\
\hline $\begin{array}{l}\text { te (unidades-animal) - } \\
\text { Pecuária de leite } B\end{array}$ & 5.040 & - & 83.349 & - & 175.033 & - \\
\hline (unidades-matriz) & 203 & - & 5.513 & - & 7.530 & - \\
\hline $\begin{array}{l}\text { Pecuăria de leite } C \\
\text { (vacas em lactaçäo) } \\
\text { Suinocultura tipo banha }\end{array}$ & 3.768 & - & 31.885 & - & 88.037 & - \\
\hline $\begin{array}{l}\text { (unidades-animal) } \\
\text { Sulnocultura tipo carne }\end{array}$ & 33.047 & - & 95.246 & - & 63.398 & - \\
\hline $\begin{array}{l}\text { (unidades-animal) } \\
\text { Pasto artificial }\end{array}$ & - & - & 35.717 & - & - & - \\
\hline $\begin{array}{c}\text { (hectares) } \\
\text { Pasto natural }\end{array}$ & 3.990 & - & 42.503 & - & 85.299 & - \\
\hline (hectares) & 10.311 & - & 137.203 & - & 337.968 & - \\
\hline
\end{tabular}

FONTE: Resultados do Modelo a Dados do IEA. 
$1974 / 75$

\begin{tabular}{|c|c|c|c|c|c|c|}
\hline \multirow[b]{2}{*}{ ATIVIDADES } & \multicolumn{6}{|c|}{ ESTRATOS } \\
\hline & \multicolumn{2}{|c|}{$\begin{array}{c}\text { Pequeno } \\
\text { Modelo Observad }\end{array}$} & \multicolumn{2}{|c|}{ Médio } & \multicolumn{2}{|c|}{$\begin{array}{l}\text { Grande } \\
\text { elo Observado }\end{array}$} \\
\hline Algodäo (hectares) & 5.158 & 2.596 & 49.673 & 65.726 & 47.394 & 49.678 \\
\hline Cana (hectares) & 6.130 & 6.601 & 67.797 & 64.766 & 133.545 & 192.532 \\
\hline Milho (hectares) & 4.083 & 13.768 & 54.184 & 62.563 & 42.352 & 30.058 \\
\hline Arroz (hectares) & 1.262 & 2.857 & 16.576 & 25.444 & 17.531 & 24.546 \\
\hline $\begin{array}{l}\text { Soja (hectares) } \\
\text { Batata das äguas }\end{array}$ & - & - & 4.176 & 1.485 & 6.027 & 12.615 \\
\hline $\begin{array}{l}\text { (hectares) } \\
\text { Batata da seca }\end{array}$ & 1.831 & - & 1.708 & - & 3.558 & - \\
\hline (hectares) & 368 & - & 1.106 & - & 674 & - \\
\hline $\begin{array}{l}\text { Mandioca (hectares) } \\
\text { Feifäo das äguas }\end{array}$ & 223 & - & 12.535 & - & 3.598 & - \\
\hline $\begin{array}{l}\text { (hectares) } \\
\text { Feijão da seca }\end{array}$ & 355 & 1.115 & 5.524 & 7.861 & 6.365 & 4.610 \\
\hline (hectares) & 422 & 262 & 4.152 & 5.963 & 7.220 & 2.463 \\
\hline $\begin{array}{l}\text { Tomate (hectares) } \\
\text { Café área total }\end{array}$ & - & - & 863 & - & 894 & - \\
\hline $\begin{array}{l}\text { (hectares) } \\
\text { Laranja (cItrus) }\end{array}$ & 5.913 & 3.087 & 25.453 & 23.184 & 63.308 & 36.729 \\
\hline $\begin{array}{l}\text { ärea total em hectares } \\
\text { Pecuária bovina de cor }\end{array}$ & 13.694 & 8.380 & 77.768 & 60.243 & 47.433 & 42.670 \\
\hline $\begin{array}{l}\text { te (unidades-animal) - } \\
\text { Pecuária de leite } B\end{array}$ & 5.040 & - & 83.349 & - & 175.033 & - \\
\hline $\begin{array}{l}\text { (unidades-matriz) } \\
\text { Pecuária de leite } C\end{array}$ & 364 & - & 8.215 & - & 9.336 & - \\
\hline $\begin{array}{l}\text { (vacas em lactação) } \\
\text { Suinocultura tipo banha }\end{array}$ & 3.964 & - & 41.132 & - & 97.337 & - \\
\hline $\begin{array}{l}\text { (unidedes-animal) } \\
\text { Suinocultura tipo carne }\end{array}$ & 33.047 & - & 104.770 & - & 63.398 & - \\
\hline $\begin{array}{l}\text { (unidades-animal) } \\
\text { Pasto artificial }\end{array}$ & - & - & 39.289 & - & - & - \\
\hline $\begin{array}{l}\text { (hectares) } \\
\text { Pasto natural }\end{array}$ & 3.990 & - & 42.318 & - & 85.299 & - \\
\hline (hectares) & 11.342 & - & 163.271 & - & 375.144 & - \\
\hline
\end{tabular}

FONTE: Resultados do Modelo e Dados do IEA. 


\begin{tabular}{|c|c|c|c|c|c|c|}
\hline \multirow{2}{*}{ ATIVIDADES } & \multicolumn{6}{|c|}{ ESTRATOS } \\
\hline & \multicolumn{2}{|c|}{$\begin{array}{c}\text { Pequeno } \\
\text { Modelo Observad }\end{array}$} & \multicolumn{2}{|c|}{$\begin{array}{l}\text { Méd1o } \\
\text { o Obser }\end{array}$} & \multicolumn{2}{|c|}{$\begin{array}{c}\text { Grande } \\
\text { to Modelo Observado }\end{array}$} \\
\hline Algodão (hectares) & 4.095 & 4.046 & 53.762 & 42.047 & 42.655 & 40.907 \\
\hline Cana (hectares) & 8.276 & 6.561 & 77.288 & 66.547 & 146.196 & 219.792 \\
\hline Milho (hectares) & 3.470 & 6.095 & 44.973 & 53.925 & 46.879 & 51.980 \\
\hline Arroz (hectares) & 1.010 & 1.581 & 15.747 & 23.715 & 16.654 & 24.242 \\
\hline $\begin{array}{l}\text { Soja (hectares) } \\
\text { Batata das águas }\end{array}$ & - & - & 3.341 & 3.090 & 7.835 & 11.910 \\
\hline $\begin{array}{l}\text { (hectares) } \\
\text { Batata da seca }\end{array}$ & 1.817 & - & 1.605 & - & 3.558 & - \\
\hline (hectares) & 294 & - & 885 & - & 539 & - \\
\hline $\begin{array}{l}\text { Mandioca (hectares) } \\
\text { Feijão das äguas }\end{array}$ & 223 & - & 12.535 & - & 3.598 & - \\
\hline $\begin{array}{l}\text { (hectares) } \\
\text { Feijão da seca }\end{array}$ & 266 & 885 & 4.143 & 5.641 & 7.320 & 1.374 \\
\hline (hectares) & 380 & 273 & 3.238 & 5.183 & 5.776 & 1.943 \\
\hline $\begin{array}{l}\text { Tomata (hectares) } \\
\text { Café área total }\end{array}$ & - & - & 777 & - & 804 & - \\
\hline $\begin{array}{l}\text { (hectares) } \\
\text { Laranja (citrus) }\end{array}$ & 6.926 & 2.804 & 30.291 & 34.349 & 71.970 & 32.947 \\
\hline $\begin{array}{l}\text { ärea total em hectares } \\
\text { Pecuária bovina de cor }\end{array}$ & 14.834 & 8.074 & 85.434 & 64.992 & 49.376 & 37.067 \\
\hline $\begin{array}{l}\text { te (unidades-animal) } \\
\text { Pecuärla de leite } B\end{array}$ & 5.040 & - & 83.349 & - & 175.033 & - \\
\hline $\begin{array}{l}\text { (unidades-matriz) } \\
\text { Pecuária de leite C }\end{array}$ & 655 & - & 12.239 & - & 11.577 & - \\
\hline $\begin{array}{l}\text { (vacas em lactação) } \\
\text { Juinocultura tipo banha }\end{array}$ & 4.114 & - & 53.060 & - & 107.527 & - \\
\hline $\begin{array}{l}\text { (unidades-animal) } \\
\text { Suinocultura tipo carne }\end{array}$ & 33.047 & - & 115.247 & - & 63.398 & - \\
\hline $\begin{array}{l}\text { (unidades-animal) } \\
\text { Pasto artificlal }\end{array}$ & - & - & 43.218 & - & - & - \\
\hline $\begin{array}{l}\text { (hectares) } \\
\text { Pasto natural }\end{array}$ & 3.990 & - & 58.399 & - & 85.299 & - \\
\hline (hectares) & 12.476 & - & 174.229 & - & 416.410 & - \\
\hline
\end{tabular}

FONTE: Resultados do Modelo a Dados do IEA. 


\section{ESTRATOS}

\section{ATIVIDADES}

Pequeno

Médio

Grande

Modelo Observado Mode lo Observado Modelo Observado

\begin{tabular}{|c|c|c|c|c|c|c|}
\hline Algodão (hectares) & 2.662 & 2.979 & 50.783 & 43.883 & 50.434 & 42.937 \\
\hline Cana (hectares) & 10.383 & 14.621 & 88.108 & - & 150.513 & - \\
\hline Milho (hectares) & 2.960 & 6.549 & 37.326 & 49.621 & 37.503 & 50.121 \\
\hline Arroz (hectares) & 808 & 3.518 & 14.959 & 17.011 & 15.821 & 23.770 \\
\hline $\begin{array}{l}\text { Soja (hectares) } \\
\text { Batata das águas }\end{array}$ & - & - & 2.673 & 2.653 & 10.185 & 8.047 \\
\hline (hectares) & 1.831 & - & 1.605 & - & 3.558 & - \\
\hline $\begin{array}{l}\text { Batata da seca } \\
\text { (hectares) }\end{array}$ & 309 & - & 885 & - & 539 & - \\
\hline $\begin{array}{l}\text { Mandioca (hectares) } \\
\text { Feijão das águas }\end{array}$ & 223 & - & 12.535 & - & 3.598 & - \\
\hline $\begin{array}{c}\text { (hectares) } \\
\text { Feljão da seca }\end{array}$ & 200 & 499 & 4.972 & 5.234 & 8.418 & 1.766 \\
\hline (hectares) & 456 & 897 & 3.594 & 6.002 & 6.931 & 2.729 \\
\hline $\begin{array}{l}\text { Tomate (hectares) } \\
\text { Café área total }\end{array}$ & - & - & 854 & - & 804 & - \\
\hline $\begin{array}{l}\text { (hectares) } \\
\text { Laranja (citrus) }\end{array}$ & 8.720 & 2.902 & 37.713 & 33.259 & 83.354 & 44.698 \\
\hline $\begin{array}{l}\text { área total em hectares } \\
\text { Pecuäria bovina de cor }\end{array}$ & 14.823 & - & 92.174 & - & 50.575 & - \\
\hline $\begin{array}{l}\text { te (unidades-animal) } \\
\text { Pecuária de leite } B\end{array}$ & 5.040 & - & 83.349 & - & 175.033 & - \\
\hline $\begin{array}{l}\text { (unidades-matriz) } \\
\text { Pecuäria de leite C }\end{array}$ & 1.180 & - & 18.235 & - & 14.355 & - \\
\hline $\begin{array}{l}\text { (vacas em lactação) } \\
\text { Suinocultura tipo banha }\end{array}$ & 4.164 & - & 68.447 & - & 103.871 & - \\
\hline $\begin{array}{l}\text { (unidades-animal) } \\
\text { Suinocultura tipo carne }\end{array}$ & 33.047 & - & 126.772 & - & 63.398 & - \\
\hline $\begin{array}{l}\text { (unidades-animal) } \\
\text { Pasto artificial }\end{array}$ & _- & - & 47.539 & - & - & - \\
\hline $\begin{array}{l}\text { (hectares) } \\
\text { Pasto natural }\end{array}$ & 3.990 & - & 80.591 & - & 63.974 & - \\
\hline (hectares) & 13.924 & - & 186.387 & - & 462.215 & - \\
\hline
\end{tabular}

FONTE: Resultados do Modelo e Dados do IEA. 